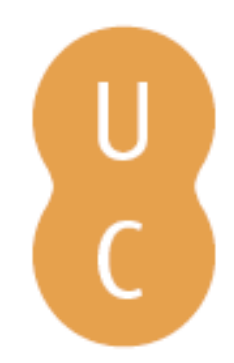

\title{
nommalina
}

\section{A água como património: experiências de requalificação das cidades com água e das paisagens fluviais}

Autor(es): $\quad$ Peixoto, Paulo, ed. lit.; Cardielos, João Paulo, ed. lit.

Publicado por: Imprensa da Universidade de Coimbra

URL

persistente: URI:http://hdl.handle.net/10316.2/39313

DOI: $\quad$ DOI:http://dx.doi.org/10.14195/978-989-26-1025-2

Accessed : $\quad$ 19-Jan-2017 14:49:00

A navegação consulta e descarregamento dos títulos inseridos nas Bibliotecas Digitais UC Digitalis, UC Pombalina e UC Impactum, pressupõem a aceitação plena e sem reservas dos Termos e Condições de Uso destas Bibliotecas Digitais, disponíveis em https://digitalis.uc.pt/pt-pt/termos.

Conforme exposto nos referidos Termos e Condições de Uso, o descarregamento de títulos de acesso restrito requer uma licença válida de autorização devendo o utilizador aceder ao(s) documento(s) a partir de um endereço de IP da instituição detentora da supramencionada licença.

Ao utilizador é apenas permitido o descarregamento para uso pessoal, pelo que o emprego do(s) título(s) descarregado(s) para outro fim, designadamente comercial, carece de autorização do respetivo autor ou editor da obra.

Na medida em que todas as obras da UC Digitalis se encontram protegidas pelo Código do Direito de Autor e Direitos Conexos e demais legislação aplicável, toda a cópia, parcial ou total, deste documento, nos casos em que é legalmente admitida, deverá conter ou fazer-se acompanhar por este aviso.

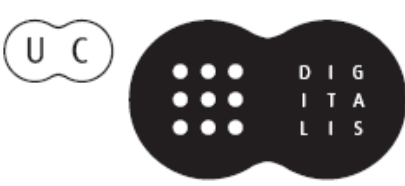


(Página deixada propositadamente em branco) 


\section{A ÁGUA COMO PATRIMÓNIO}

EXPERIÊNCIAS DE REQUALIFICAÇÃO DAS CIDADES

COM ÁGUA E DAS PAISAGENS FLUVIAIS

PAULO PEIXOTO

JOÃO PAULO CARDIELOS

(ORGS.) 
COORDENAÇÃO EDITORIAL

Imprensa da Universidade de Coimbra

CONCEPÇÃO GRÁFICA

António Barros

INFOGRAFIA

Mickael Silva

IMAGEM DA CAPA

As imagens da capa são relativas à instalação coordenada por António Olaio e Pedro Pousada no âmbito da exposição "O Rio Voador". Integrada no projeto EPAT (Água como Património) a exposição decorreu no Museu da Água de Coimbra, entre 14 de Fevereiro e 11 de Abril de 2012. A capa reproduz os trabalhos, em papel recortado, coordenados por Alice Geirinhas e uma peça suspensa, produzida sob a coordenação de António Olaio e Pedro Pousada. Ambos os trabalhos foram produzidos por alunos que, dessa forma, participaram no projeto EPAT.

EXECUÇÃO GRÁFICA

Simões e Linhares, Lda.

ISBN

978-989-26-1024-5

ISBN DIGITAL

978-989-26-1025-2

DOI

http://dx.doi.org/10.14195/978-989-26-1025-2

DEPÓSITO LEGAL

408560/16

C 2016, IMPRENSA DA UNIVERSIDADE DE COIMBRA 

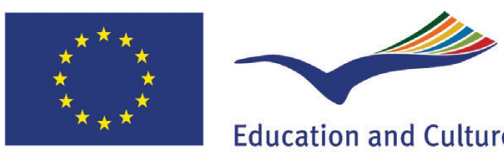

Education and Culture DG

\section{Culture Programme}

Esta obra é a versão em português de um projeto internacional, realizado em 4 países, financiado pela Comissão Europeia.

Os autores são os únicos responsáveis pelos conteúdos deste livro, não podendo a Comissão Europeia ser responsabilizada pelas pela informação aqui divulgada.

Uma versão mais longa desta obra foi publicada (com textos em italiano, francês e inglês) pela editora Aracne, Roma, sob a organização de Romeo Farinella (Coordenador Geral do projeto EPAT Eau comme patrimoine). 
(Página deixada propositadamente em branco) 
À Marica Solomon

\section{Entre o Sono e Sonho}

Entre o sono e sonho,

Entre mim e o que em mim

É o quem eu me suponho

Corre um rio sem fim.

Passou por outras margens,

Diversas mais além,

Naquelas várias viagens

Que todo o rio tem.

Chegou onde hoje habito

A casa que hoje sou.

Passa, se eu me medito;

Se desperto, passou.

E quem me sinto e morre

No que me liga a mim

Dorme onde o rio corre -

Esse rio sem fim. 
(Página deixada propositadamente em branco) 


\section{ITÁLIA}

\section{CO-ORgANIZADORES}

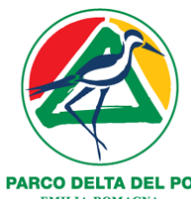

Ente di Gestione per i Parchi e la Biodiversità - Delta del Po

Lucilla Previati - Coordenadora

Anna Luciani

Michele Ronconi

Maria Cristina Veratelli

\section{DA siter}

\section{Università degli Studi di Ferrara - Dipartimento di Architettura}

CITER - Laboratorio di Progettazione Urbana e Territoriale

Romeo Farinella - Coordenador

Alice Clementi

Elena Dorato

Saveria Olga Murielle Boulanger

Nicola Tosi

Alessandro delli Ponti - Séminaire Robert Auzelle

Andrea Noferini

Laura Belotti

Angela Cavallo

Roberta Corradetti

Eleonora Fraternali

Silvia Tarantini

Beatrice Tassinari

Antonella Trusgnach 


\section{PARCEIROS}

\section{Amministrazione Provinciale di Ferrara}

Settore Pianificazione Territoriale, Mobilità, Energia, Lavoro e Formazione Professionale

\section{Amministrazione Comunale di Comacchio}

Claudio Fedozzi

Giuseppe Guidi

\section{ACER Azienda Casa Emilia Romagna-Ferrara}

Daniele Palombo

Diego Carrara

Marco Cenacchi

\section{Colaboração}

\section{Living Urban Scape}

Milena De Matteis

Alessandra Marin

Valeria Leoni

Ianira Vassallo

Barbara del Brocco

Daniele Carfagna

Marianna Mazzetta 


\section{PORTUGAL}

Co-organizadores

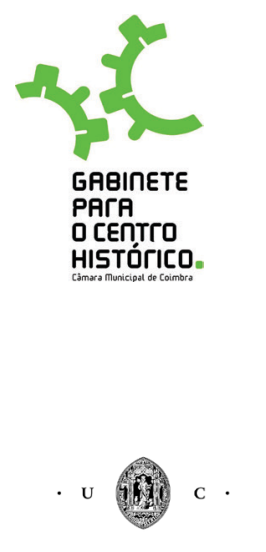

UNIVERSIDADE DE CoIMBra

Paulo Leitão

Rosa Silva

PARCEIROS

\section{Gabinete para o Centro Histórico}

Magda Brígida Lucas

\section{Universidade de Coimbra}

DArq - Departamento de Arquitectura

FEUC - Faculdade de Economia

António Olaio

João Paulo Cardielos

Rui Lobo

Eduardo Mota

Joana Melo

João Pedro Pedrosa

Luís Gonçalves

Paulo Teixeira

Pedro Caiado

Tiago Martins

CES - Centro de Estudos Sociais
Claudino Ferreira

Paulo Peixoto - Coordenador

Márcia Abreu

Francisco Freitas

Giovanni Allegretti

Milton Vogado

Nancy Duxbury 


\section{ROMÉNIA}

\section{CO-ORgANIZADORES}

Universitatea de Arhitectura si Urbanism Ion Mincu Centrul de Studii Arhitecturale si Urbane

Marica Solomon †

Nicolae Lascu - Coordenador científico

Andreea Mirela China

Andreea Popa

Liviu Veluda

Iulia Catalina Cucu

Georgia Manuela Ion

Alexandra Elena Petraru

Andrei Pomana

Parceiros

Braila County Council (CJB)

Costel Dragan

Braila City Council - Braila City Hall (CLB)

Marian Ion

\section{Colaboração}

Doina Bubulete

Raluca Iosipescu

Sergiu Iosipescu 


\section{FRANÇA}

\section{Co-Organizadores}

Ville de Lille osf Municipalité de Lille

Philippe Delahaye

Mathieu Goetzke

Véronique Falise

Dorothée Delemer

Richard Lemeiter

Julien Pinon

\section{FL $\equiv \mathbf{A L}_{\text {lt }} \quad$ Fluvial Consult \\ Pierre Peyret \\ Nicoletta Peyret}




\section{PARCEIROS}

IAUL ||||| IAUL - Institut d'Aménagement et Urbanisme de Lille du département de I'U.F.R. de Géographie de I'Université Lille1 Sciences et Technologies

Pauline Bosredon

Kristel Mazy

Cédric Riviere

Philippe Hurtaux

Zoé Charge

Ségolène Meheust

$\underset{\text { architecture \& paysage }}{\operatorname{ens}}$

ENSAPL - Ecole Nationale Supérieure d'Architecture et de Paysage de Lille Armelle Varcin

Jean Michel Mercher

Bénédicte Gresjean

François Andrieux

L'ensemble des étudiants de I'Atelier 0 - 2012-13 


\section{Prefácio}

Maguelonne Déjeant-Pons

Água como património. Passado, presente, mas, sobretudo, futuro Lucilla Previati

Cidade, água, património. As razões de um projeto

Romeo Farinella

Vias de água, paisagens: a noção de património fluvial

Pierre Peyret

Os usos sociais dos rios

Paulo Peixoto

Introdução

Pierre Peyret

Braila: cidade no Danúbio

Nicolae Lascu, Andreea Mirela China

Mondego: o surdo murmúrio do rio

João Paulo Cardielos, Rui Lobo, Paulo Peixoto,

Eduardo Mota, Nancy Duxbury, Pedro Caiado

Comacchio: leitura de um território

Lucilla Previati, Michele Ronconi, Elena Dorato,

Alice Clementi, Anna Luciani, Justina Soltysiuk 
Lille: leitura do território e estratégia urbana

(para a água/pela água)

Richard Lemeiter, Julien Pinon, Cédric Riviere

PROJETOS

Introdução

Romeo Farinella

Braila: onde o Danúbio vem à cidade

Nicolae Lascu, Andreea Mirela China

Coimbra: a cidade à procura de um rio

João Paulo Cardielos, Rui Lobo, Paulo Peixoto, Eduardo Mota

Comacchio: água no plural

Lucilla Previati, Michele Ronconi, Elena Dorato,

Alice Clementi, Anna Luciani, Justina Soltysiuk

Lille: a dimensão cultural da água

Richard Lemeiter, Julien Pinon, Cédric Riviere

\section{CONSIDERAÇÕES FINAIS}

Paulo Peixoto 


\section{PREFÁCIO}

Maguelonne Déjeant-Pons

Head of the Cultural Heritage, Landscape and Spatial Planning Division

Directorate of Culture, Cultural and Natural Heritage

Conselho da Europa 


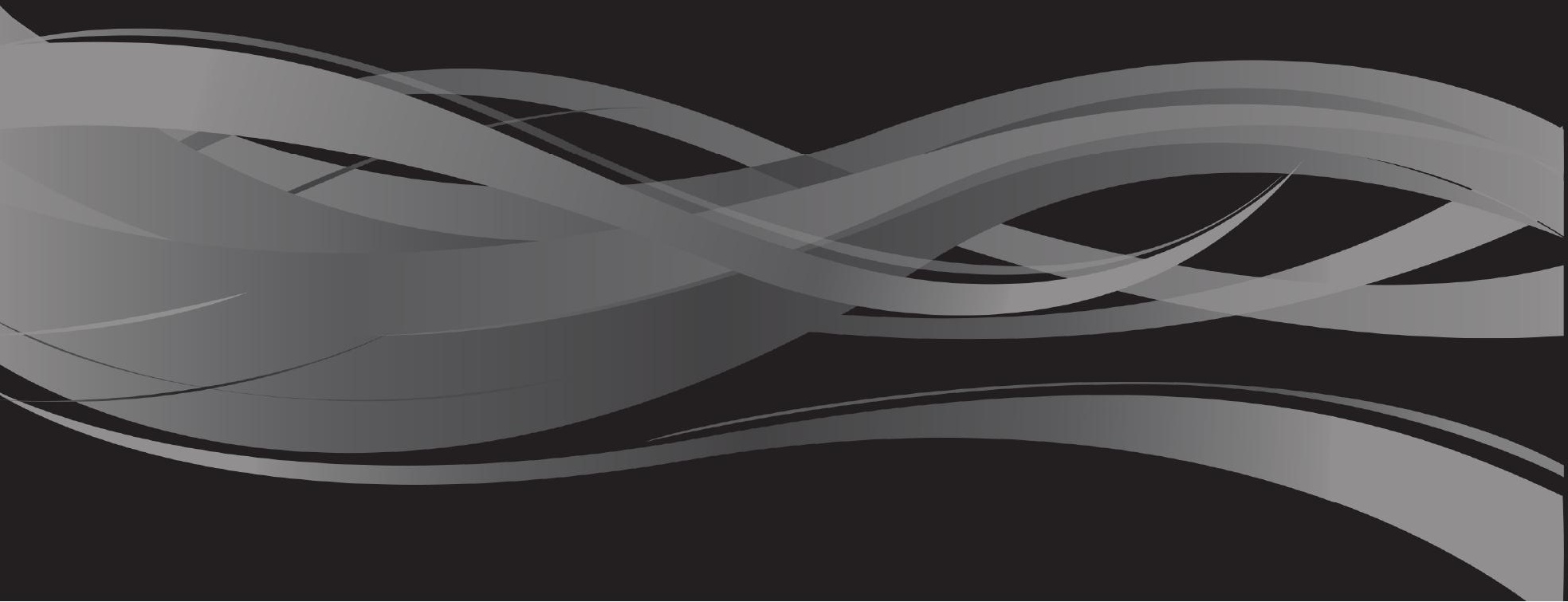


Manifesto um carinho particular pela nossa querida amiga e eminente Professora de arquitetura, Marica Solomon, que, com uma sensibilidade muito particular e uma competência reconhecida ao nível internacional, promoveu a consciênca paisagística, nos seus trabalhos e na sua vida. O título da obra "A água como património: experiências de requalificação das cidades com água e das paisagens fluviais", apresenta-se como um convite para pensar e repensar o valor da água e para apreender todas as suas dimensões.

Em 1967, o Comité de Ministros do Conselho da Europa declarou, na Carta europeia da água, "Não há vida sem água. Trata-se de um bem precioso, indispensável a todas as atividades humanas". A água é para os humanos, para os animais e para as plantas um elemento de primeira necessidade. Indispensável como bebida e alimento, para a higiene e como fonte de energia, a água representa uma matéria prima de produção, uma via de transporte e constitu-se como suporte de atividades recreativas. Ela encontra-se, por isso, mais do que nunca, no centro das preocupações do desenvolvimento sustentável que reúne dois aspetos fundamentais da sociedade: a necessidade de proteger o ambiente e de melhorar as condições de vida dos seres humanos.

"Água como património". O título desta obra remete-nos igualmente para a dimensão cultural, simbólica, espiritual e paisagística da água. No centro das nossas vidas, no centro das nossas cidades e das nossas aldeias, a água irriga tanto os nossos corpos e os nossos pensamentos, quanto os territórios em que crescemos.

A coordenação científica do Laboratório CITER da Universidade de Ferrara, a direção do projeto por intermédio da Agência do Parque do Delta do Pó da Região da Emília Romana, o empenho assinalável que a cidade de Lille, a cidade e a universidade de Coimbra, a universidade Ion Mincu de Bucareste colocaram no desenvolvimento dos trabalhos foi determinante para a conceção e o êxito do projeto. Felecitamos de modo particular a FluvialConsult e os seus responsáveis, Pierre Peyret e Nicoletta Peyret que, com talento e muita competência no domínio das paisagens fluviais e de experiências com vias de água interiores internacionais, participaram na realização do programa.

A obra incorpora de uma forma decidida os valores patrimoniais e paisagísticos da água numa reflexão prospetiva sobre as políticas de desenvolvimento do território.

Apresenta experiências participativas e conhecimentos valiosos em prol de uma proteção, de uma gestão e de um ordenamento apropriado das paisagens das cidades de água e dos rios, enquadrando-se no espírito da Convenção europeia da paisagem. A paisagem, as paisagens de água, desempenham um papel importante enquanto elemento ambiental e do quadro de vida das populações. As autoridades públicas, assim como a sociedade civil, estão desde logo convidadas a desempenhar um papel ativo na sua proteção, sua gestão e ordenamento e a sentir-se responsáveis pelo seu futuro.

A preservação e a gestão de recursos aquíferos considerados como patrimónios das cidades de água e dos rios inscreve-se, assim, num largo processo evolutivo que conduz a uma tomada de consciência acrescida relativamente à importância de que se revestem as questões ambientais, culturais e paisagísticas para as sociedades.

Os leitos fluviais e os vales aluviais representam outro grande desafio para o ordenamento do território. Muito frequentemente caracterizados por elementos naturais de grande valor, tornam-se 
alvos de pressões intensivas que resultam de atividades ou instalações humanas. Por isso mesmo, é necessário que a utilização que é feita destes espaços seja sustentável. O desenvolvimento da economia, entendido como o conjunto de atividades humanas, deve obviamente prosseguir, mas a qualidade do ambiente - que abrange num sentido amplo os processos ecológicos e os diversos recursos naturais de que dependem os organismos vivos - deve ser preservada.

É necessário que a perenidade dos recursos naturais seja assegurada de modo a poder satisfazer as necessidades e as aspirações das gerações presentes e futuras. É necessário reconhecer os recursos aquíferos como um património, e reconhecer a água como um património. Por isso, neste sentido, é essencial, como bem o revela este livro, favorecer a redescoberta da importância dos rios europeus e das paisagens de água nas estratégias de reabilitação das cidades ou de outros territórios europeus. 


\section{A ÁGUA COMO PATRIMÓNIO PASSADO, PRESENTE MAS, SOBRETUDO, FUTURO}

LUCILLA PREVIATI 


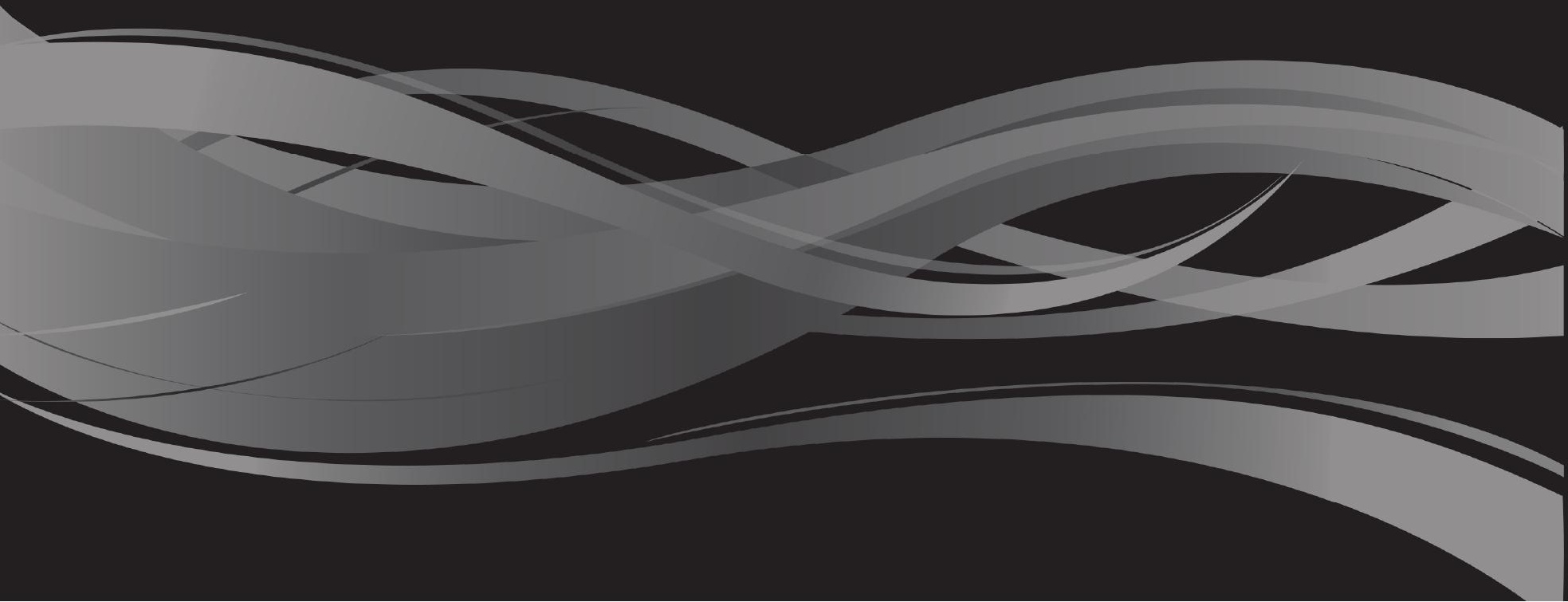


O peso, cada vez mais relevante, que as alterações climáticas têm nas dinâmicas ambientais, mas também sociais e económicas, do mundo contemporâneo, leva à necessidade de pensar e elaborar novas políticas para a gestão dos recursos naturais e ambientais, baseadas num conceito de desenvolvimento sustentável que parta da valorização e tutela do ambiente, da revalorização económica e social da realidade territorial envolvida e, por fim, que saiba promover atividades dinâmicas de "auto-regeneração" dos recursos.

O "Livro Branco" da União Europeia, sobre a adaptação às alterações climáticas, define uma estratégia com o intuito de tornar a U. E. menos vulnerável perante os impactos destas mudanças. O quadro estratégico definido baseia-se em quatro ações principais:

- Construir uma base sólida de conhecimentos sobre os impactos e as consequências das alterações climáticas;

- Integrar o desiderato da adaptação nas principais políticas da U. E.;

- Utilizar uma combinação de instrumentos político-estratégicos (entre os quais instrumentos de mercado e linhas de orientação), para garantir um eficaz cumprimento dos objetivos;

- Acelerar a cooperação internacional.

A adaptação é fundamentalmente local, dado que os impactos das alterações climáticas variam de região para região, mas consiste num desafio de grande alcance, já que a necessidade de adaptação é partilhada pela maior parte dos processos naturais e das atividades humanas.

A Direcção Geral "Ações para o clima" está a trabalhar, em conjunto com outros serviços da Comissão Europeia, para especificar as medidas qualitativas concretas a pôr em execução, preconizando, desde 2013, uma estratégia de adaptação climática. Um dos temas centrais da estratégia é a política em matéria de águas, que se torna um argumento central e prioritário nos debates essencialmente ambientais, mas também sociais, económicos, urbanísticos e culturais.

Para o Delta do Pó e para Comacchio, a sua cidade mais representativa (pelo menos na parte Emiliana), a água tem sido, desde sempre, portadora de economia, determina os perfis sócio-económicos das suas gentes, caracteriza o seu território e desenha a sua paisagem.

Como principal recurso dos territórios costeiros desenvolve, acima de tudo, inúmeras funções ecossistémicas e está no centro de numerosos interesses, às vezes contraditórios entre si, de utilização na agricultura (um dos usos mais avançados e qualificados do mundo), no transporte e no turismo.

Garantir a qualidade e a correta gestão permanece um dos objetivos prioritários da entidade de gestão Parques e Biodiversidade - Delta do Pó, instituição tutelada pela Lei Regional n. 24, de 23 de dezembro de 2011, que prossegue as atividades de tutela e de valorização do Parque Regional do Delta do Pó Emiliano, estendido ao longo da costa adriática de Goro a Cervia e que contem, dentro dos seus 54.000 hectares, um complexo de zonas húmidas que está entre as mais importantes e ricas em biodiversidade da Europa.

Para enfrentar os possíveis problemas de reduzida disponibilidade de água para irrigação, provocados pelas mudanças de clima e pela exigência de conservação dos ecossistemas aquáticos, e, ao 
mesmo tempo, para levar a cabo ações de encaminhamento, numa rede de escoamento adequada, das quantidades provenientes das violentas e cada vez mais abundantes e imprevisíveis precipitações, surge uma nova ideia de «Delta», em que uma estratégia consolidada de requalificação da rede de águas se integre com a regeneração das paisagens costeiras, criando um ressarcimento ecológico para toda a planície do Pó, da qual o Delta constitui o bio-filtro: uma "nova reabilitação paisagística" a partir do acabamento em pedra da rede hidrográfica secundária (composta pelos canais reabilitados), as zonas de expansão dos principais cursos de água, os serviços da rede de águas em terrenos agrícolas pouco produtivos, a inclusão de reservatórios escoamento das águas do mar (como é o caso de Valle Fattibello em Comacchio, Piallasse em Ravenna ou Saline).

A recente discussão iniciada pelo Ministério da Coesão Territorial, em conjunto com outros Ministérios italianos, para a programação de Fundos Comunitários 2014-2020 e o trabalho em curso para o Plano Estação «Centro histórico de Comacchio, componente estratégica do próximo Plano Estrutural Comunal, levam à reflexão em termos estruturais da "água como património".

É possível ler-se, na página 60 do relatório do Ministro Barca, com o título "Métodos e objetivos para um uso eficaz dos fundos comunitários 2014-2020" (Roma, 27 de dezembro de 2012):

“... o governo das bacias hidrográficas, a qualidade das águas e a melhoria dos serviços são os principais objetivos a atingir (...). A tutela e a qualidade da água serão garantidas através de práticas agrícolas compatíveis e incentivando a reutilização das águas tratadas de modo a reduzir a extração de águas (...). Em relação à tutela e à promoção dos bens naturais e culturais, em matéria de Biodiversidade, o objetivo é pôr em prática políticas para completar e sustentar a gestão da Rede Natura 2000, no âmbito terrestre e marítimo, para valorizar as iniciativas de desenvolvimento económico e social dos territórios (...). As ações deverão favorecer a protecção da biodiversidade biocultural ligada à paisagem. (...) As medidas Agro-ambientais (...) serão postas em prática com uma abordagem mais inovadora (...). Sobretudo as ações de biodiversidade aplicadas no território rural deverão favorecer não o resultado de abandono ou de naturalização, mas sim a manutenção ou a recuperação da biodiversidade característica da paisagem rural italiana..."

E ainda, entre as ações prioritárias para o cumprimento destes objetivos, a necessidade de "garantir melhores serviços ambientais para os cidadãos", tutelando e promovendo os bens naturais e culturais através de:

-ações previstas no "Prioritized Action Framework" (PAF) redigidas pelas regiões que conjuguem as ações de tutela com a valorização económica dos recursos existentes, ativando as comunidades locais;

-ações previstas nos Planos de gestão e/ou de salvaguarda da Rede Natura 2000;

-intervenções para a valorização de áreas de atração cultural e natural, caracterizadas pela presença de recursos culturais (museus, monumentos, áreas arqueológicas, bens 
arquitetónicos e paisagísticos) e naturais (parques naturais, áreas protegidas e locais de interesse naturalístico) de relevância nacional susceptível de consolidar e promover processos de desenvolvimento fundados na atração de recursos exógenos e na mobilização de recursos endógenos;

-intervenções voltadas para a promoção de indústrias culturais e criativas ligadas à valorização dos recursos culturais e à capacidade de fazer do território um criador de incubadoras de empresas especializadas; realização de redes de administração (em particular as universidades, museus, institutos culturais) para experiências de empreendedorismo criativo; promoção de projetos empreendedores criativos e de projetos de cidadania ativa;

- Intervenções com o intuito de consolidar os sistemas agrícolas extensivos, em particular os que se dedicam à valorização das raças animais e vegetais ameaçadas pela erosão genética ou pela extinção".

Neste sentido, e de acordo com as linhas políticas estratégicas a serem elaboradas a nível europeu e nacional, a Entidade de Gestão dos Parques e da Biodiversidade - Delta do Pó empenhou-se concretamente, ao longo dos últimos anos, propondo, ativando e participando em diversos projetos a nível europeu, com o objetivo principal de aprofundar, analisar e intervir sobre o território, definindo novas políticas estratégicas de intervenção, elaborando projetos de requalificação e valorização e perseguindo objetivos de desenvolvimento sustentável, dando particular atenção às novas exigências naturais, ambientais, paisagísticas e climatéricas.

O projeto "água como património" representa, neste sentido, uma experiência de reflexão teórica a nível de projeto e uma ocasião de comparação internacional, através do trabalho de equipa promovido e incentivado pelo Programa Cultura 2007-2013, e de diálogo com o contexto ambiental, político e cultural local. O objetivo principal do Projeto foi a redescoberta da importância dos rios e das paisagens de água para as estratégias de relançamento económico, assim como de requalificação e valorização, tanto urbana como paisagística, do território costeiro. Este objetivo surge da consciência da extrema riqueza antropológica que estes elementos tiveram, desde sempre, na história da civilização humana, tornando os territórios, um pouco por todo lado, elementos estruturantes, assim como proporcionando condições de base de muitos dos bens económicos e sociais das populações instaladas.

O âmbito escolhido para "pensar o futuro" nos territórios costeiros é local, situado no território municipal de Comacchio, um estudo de caso de extremo interesse, pois foi uma paisagem desde sempre configurada e transformada pelos sistemas de controlo, saneamento e exploração das águas. Só depois do segundo pós-guerra esta simbiose entre a pressão humana e o sistema das águas se reduziu progressivamente, com efeitos negativos no atual ordenamento do território. O passado deixou, porém, numerosos testemunhos, muitos deles tornados património histórico e museológico, outros ainda em utilização, que permitem, se forem valorizados adequadamente, percorrer a génese e as modificações do território. 
A riqueza antropológica da área constitui uma potencialidade de primeiríssima importância, uma vez que a água e os valores ambientais, paisagísticos e culturais dos quais se faz porta-voz, constituem:

-elemento estruturante para o território;

-condição de base para a economia e a sociedade local.

Os objetivos do projeto pretendem propor uma mudança substancial de direção em matéria de escolhas de planificação, redescobrindo a importância dos rios e dos percursos de água nas estratégias de relançamento económico e nos processos de requalificação e valorização urbana e paisagística do território costeiro.

A água, neste sentido, é entendida como "nova norma urbanística", dotada de um grau de obrigatoriedade em cada escolha que inclua uma transformação do território. Uma água que assuma formas plurais, à semelhança de outros elementos urbanísticos, assumindo, dependendo dos casos, um ou mais dos seguintes estatutos: espaço público, infra-estrutura para a mobilidade, mecanismo para o controlo hídrico, âmbito produtivo, elemento de valor ambiental, nó ecológico, componente da paisagem, etc.

A água, nas suas várias formas, torna-se um elemento e ocasião de reflexão sobre a necessidade de definir uma nova abordagem e um novo método de interpretação do território, compreendido no seu conjunto (natural, rural e urbanizado) e, consequentemente, na necessidade de imaginar novas propostas, novas formas e novos caminhos para o desenvolvimento do território, interrompendo o processo de consumo do solo, muitas vezes causa de um consumo paralelo de valores e identidade, e concentrando as novas e futuras políticas de desenvolvimento a favor do reconhecimento e da valorização do património existente.

O projeto "Água como património" propõe, portanto, o retorno ao uso sapiente dos sistemas das águas como possível alternativa (ou contributo) às atuais práticas urbanísticas, que demonstraram incapacidade em poder governar, com eficácia e eficiência, um território extremamente complexo e contraditório, como é o caso do território de Comacchio.

As lagoas representam ambientes altamente produtivos do ponto de vista biológico, por isso, é de relevante importância preservar a sua funcionalidade ecossistémica; mas tornou-se necessário, ao mesmo tempo, considerar a lagoa, mais que um espaço natural, um local depositário de testemunhos de uma possível e feliz convivência entre natureza e cultura, incluindo também, entre os aspetos a tutelar, a atividade antrópica.

Neste sentido, no respeito dos valores identitários e patrimoniais dos quais o território se faz porta-voz, através da comparação sempre aberta entre a realidade local e internacional, é necessário pensar, hoje, em novas paisagens de qualidade. As temáticas relativas à água, além de implicações, económicas, políticas e sociais de vasta importância, abrem desafios ricos em tensão a nível do conteúdo do projeto. Experiências pontuais, inseridas porém em cenários estratégicos de escala territorial, devem delinear novas metodologias e modelos de desenvolvimento integrado, em que as paisagens se tornem capazes de tutelar e de regenerar os recursos, através do distanciamento em relação ao papel até agora desempenhado de mero contexto. 


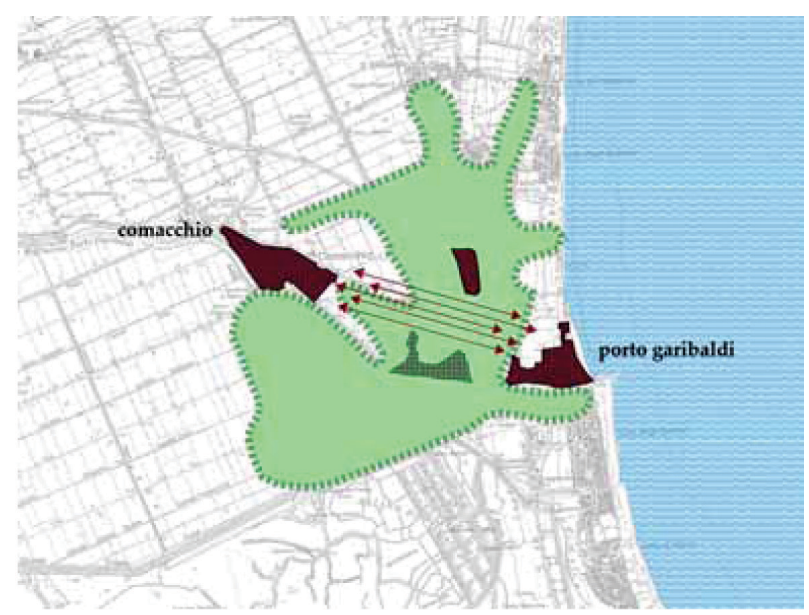

A conexão entre Comacchio e a faixa costeira (parque da cidade)

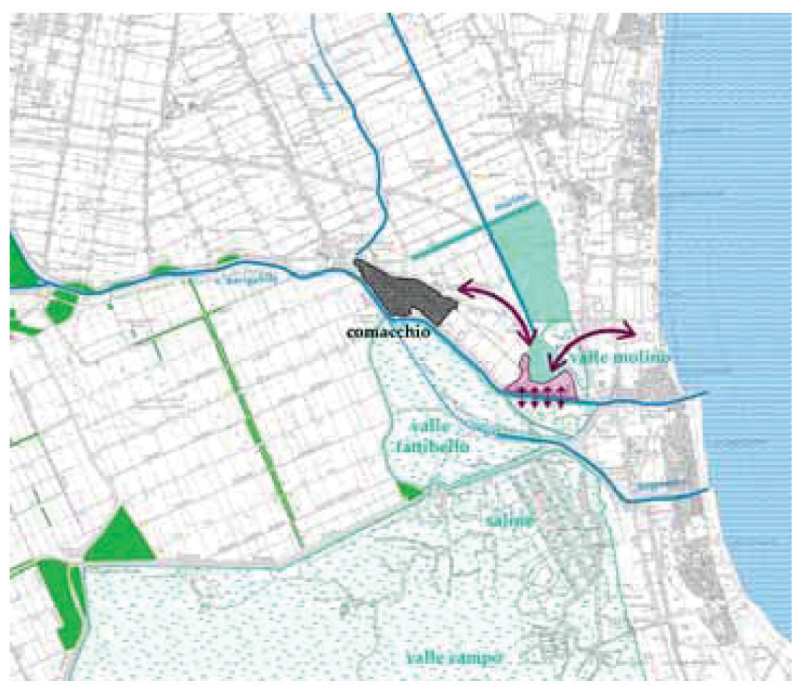

Sistema de águas interiores

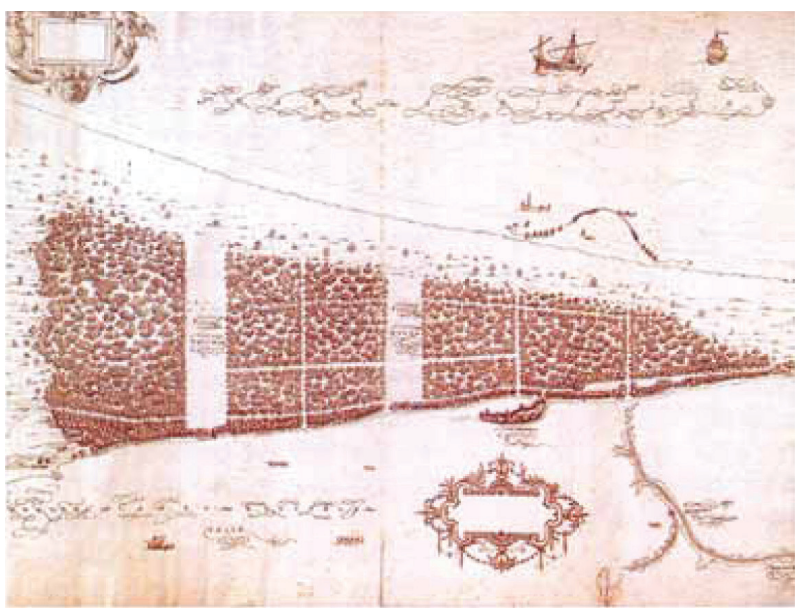

Floresta Eliceo e antigo sistema de dunas

Fonte: relazione P1 - Piano Stazione Centro Storico di Comacchio (adozione 20/12/2012), Moreno Po 


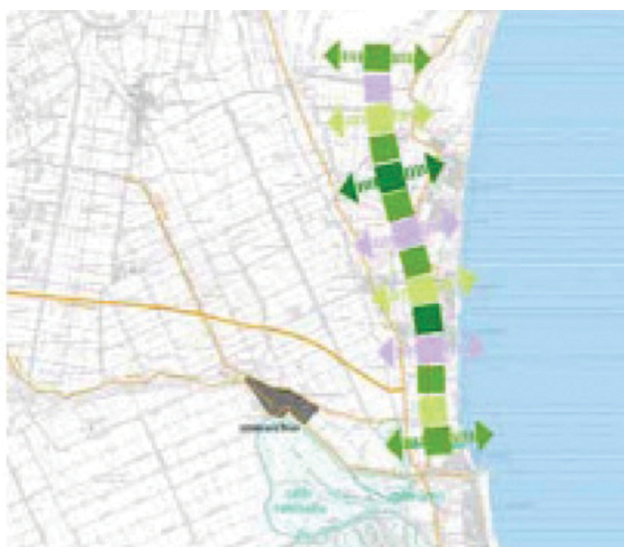

Floresta Eliceo e antigo sistema de dunas

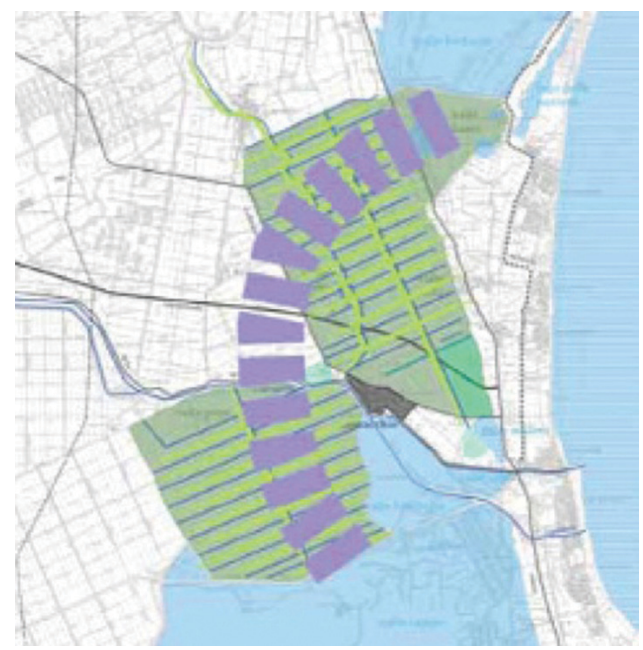

Vale Ilha

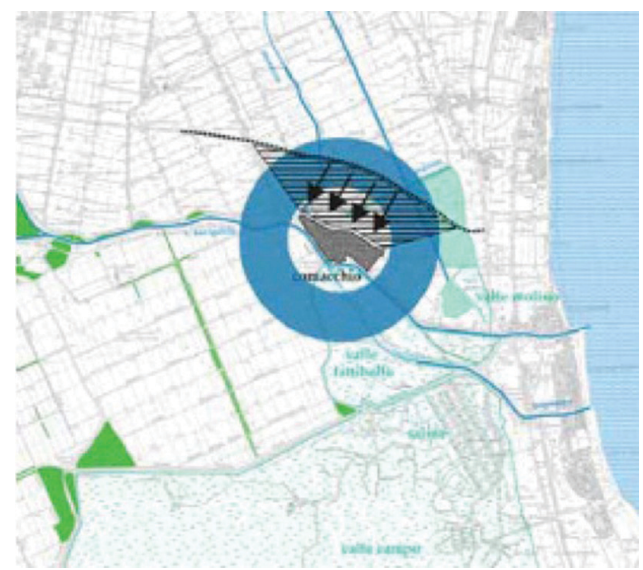

Centro histórico

Fonte: relazione P1 - Piano Stazione Centro Storico di Comacchio (adozione 20/12/2012), Moreno Po 


\section{PROBLEMÁTICAS}




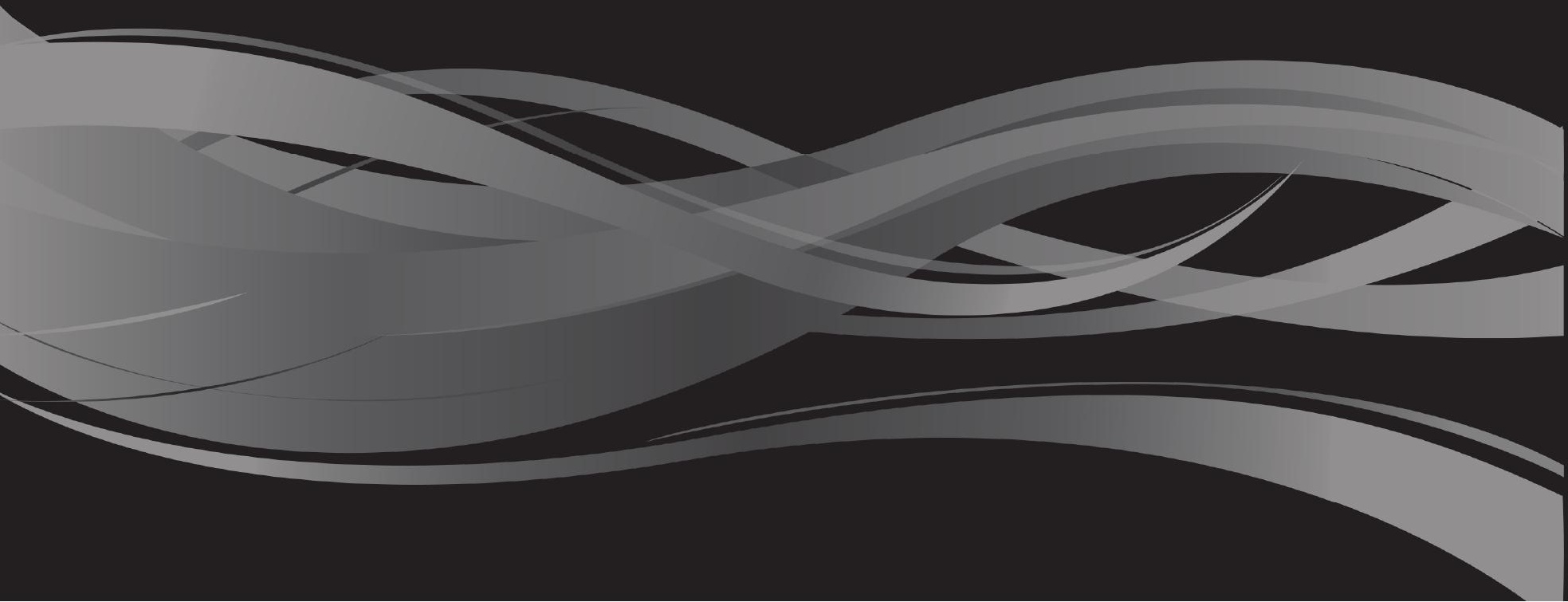




\section{CIDADE, ÁGUA, PATRIMÓNIO AS RAZÕES DE UM PROJETO}

ROMEO FARINELLA 


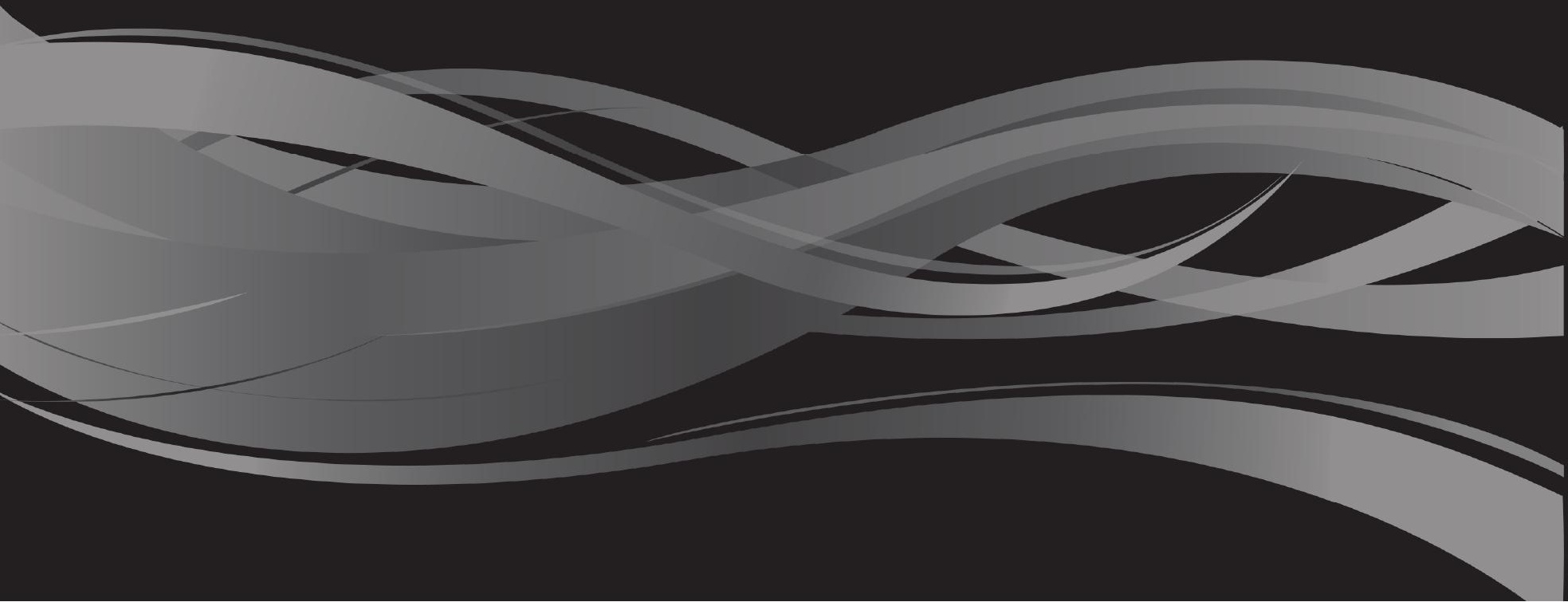




\section{ÁGUA COMO PATRIMÓNIO: A PROBLEMÁTICA}

Em dezembro de 1969, André Chastel fechava um editorial no quotidiano Le Monde, dedicado ao tema da requalificação da zona parisiense de Halles, exprimindo a sua perplexidade sobre a anunciada e, de seguida, concretizada destruição do antigo mercado. O historiador relembrava a atmosfera plena de história e cultura presente naquele espaço fascinante, intimamente ligada às estradas, às fachadas e ao ambiente do contexto urbano circundante, construído ao longo dos séculos. Devido a esta sedimentação, afirmava Chastel (2012), muitas vezes, o aspeto limpo e um pouco infantil das modernas requalificações parece um produto de laboratório, desapegado da história. A história, continua o historiador, é um aspeto do problema a controlar e que obriga a um pouco de complexidade.

Esta complexidade é, sem dúvida, um aspeto forte da sua reflexão, por vários motivos. Enunciemos alguns. Toda a modernização da cidade proposta pelas grandes teorias urbanísticas do fim do século XIX e, muitas vezes, executada contra os preceitos dos pais fundadores da urbanística, baseia-se num princípio de simplificação ditado por exigências higiénicas, de circulação, de reorganização funcional dos espaços de vida e trabalho, necessárias para acabar com a promiscuidade que sempre tinha caracterizado o crescimento da cidade pós-industrial. A cidade tende a tornar-se uma máquina onde cada componente desenvolve a sua tarefa, mas no seu respetivo espaço.

Na realidade, a racionalização dos nossos espaços urbanos respondeu a exigências de simplificação ditadas pelos impulsos do mercado imobiliário e das especulações que construíram a cidade contemporânea. Hoje, a complexidade está na base do pensamento sustentável.

Quando Chastel chamou a atenção para a complexidade da história como "material" do projeto urbano, como diríamos hoje, em França estava a chegar ao fim o período denominado Trentes Gloriueses.

É o período que os italianos conhecem como "Boom económico". Entre 1945 e 1973, o modelo de desenvolvimento baseou-se exclusivamente na ilusão do crescimento económico ilimitado.

A metrópole crescia a olhos vistos e o Presidente da Câmara Delauvrier tinha por objetivo dar formas e dimensões de cidade à enorme banlieue parisiense. São várias as histórias a este propósito que marcaram a transformação das nossas cidades ao longo do século XX.

Uma década antes, em 1957, numa conferência do Instituto Italiano de Urbanística dedicado à defesa e valorização da paisagem urbana e rural' , Adriano Olivetti declarava o seguinte:

“...podemos afirmar de firme consciência que o problema da conservação do património artístico e natural não é tanto um problema técnico e crítico, mas sim um problema político e moral. Uma sociedade que aspire verdadeiramente a ser mais elevada e melhor deve abordar a questão pelo todo".

1 Trata-se da Conferência da INU “Defesa e valorização da paisagem urbana e rural, ocorrida em Lucca, em 1957. 
Esta afirmação exprime de forma sintética a complexidade do tema da conservação dos centros históricos e da paisagem na experiência urbanística italiana da segunda metade do século XX. A importância da história emerge nas visões de Chastel e de Olivetti como portadora de uma ideia mais avançada de sociedade que considera o seu património como ponto de partida para um projeto de futuro.

O conceito de património é uma noção recente, moderna, como referiu Françoise Choay (1993). Através da retórica dos monumentos, ao longo do século XIX e início do século XX, forjaram-se as identidades nacionais europeias. A cultura iluminista e a Revolução Francesa lançaram a ideia da conservação do património como objeto das políticas nacionais. O século XIX foi o século em que se puseram em prática ações que levaram à consolidação das legislações nacionais. Em 1837, instituiu-se a Commission des Monuments Historiques graças à ação de Prosper Mérimée. Esta comissão fez trabaIhos de inventariação e de classificação e encarregou-se de formar os arquitetos que iriam intervir na conservação dos monumentos. Quarenta anos depois, em Inglaterra, William Morris fundou a Society for the Protection of Ancient Buildings. No início do século XX, emergiu também o tema da natureza como objeto de tutela. Nos Estados Unidos, Theodore Roosevelt lançou uma campanha para a salvaguarda da natureza como caráter identitário da nova nação e como obrigação moral para as gerações futuras (Settis, 2010). O processo, já iniciado sob a presidência de Lincoln, com a instituição do parque de Yosemite, na Califórnia, completou-se com a formação, em 1916, da agência federal encarregue da gestão do National System Park. Em Itália, as diversas normas introduzidas pelos antigos estados nas sucessivas ações de legislação preocuparam-se mais com questões de tutela e património do que com a unidade do país. Durante o vinténio fascista, a promulgação da nossa atual Constituição republicana marcou a evolução das políticas de tutela no nosso país (idem).

Hoje, além das legislações nacionais que determinam a ação dos vários países, existem alguns fatores que tornam mais complexo o quadro operativo. Trata-se da função das organizações internacionais que interagem, mais ou menos diretamente, com as políticas nacionais urbanas, territoriais e de tutela do património. Por exemplo, os acordos de redução de emissões de gases com efeito de estufa para a atmosfera, iniciados em 1997, em Kyoto, colocam à comunidade internacional o problema de qual o modelo de desenvolvimento a seguir; as consequências dos gases nas cidades interessam para a relação entre a conservação dos edifícios históricos e a sua preparação do ponto de vista do consumo energético. Por sua vez, a paisagem urbana poderia ser reinventada em caso de concretização das hipóteses de reflorestação urbana elaboradas para a reorganização de muitas áreas urbanas e metropolitanas europeias.

Em 2007, a União Europeia promulgou a Carta de Lipsia para as cidades sustentáveis, incentivando os estados membros a iniciarem um debate político para compreender como integrar as estratégias, com base na Carta, nas políticas de desenvolvimento nacional, regional e local. No centro da reflexão e das futuras ações está a necessidade de alcançar um desenvolvimento urbano integrado, de modo a promover uma organização territorial equilibrada e policêntrica. As cidades devem ser repensadas como organismos compactos com uma estreita ligação às zonas naturais e rurais preservadas, revalorizadas ou projetadas. Esta ideia baseia-se no conceito de qualidade urbana entendida como síntese da qualidade ambiental, social e económica e dos espaços públicos. 
O tema da paisagem como base para as políticas urbanas e territoriais foi sancionado em 2000 pela Convenção Europeia da Paisagem. Trata-se de uma iniciativa do Conselho da Europa que é um organismo mais amplo em relação à União Europeia e incluiu países que não pertencem à União Europeia. A convenção apresentada em Florença foi depois assinada e ratificada apenas por 35 países e entre estes não fazem parte a Alemanha e a Áustria. De que se trata? Certamente que não é uma norma que comporta uma adaptação automática às legislações nacionais dos países que a subscreveram. É um documento que promove e estimula a atenção à paisagem como fator estrutural das políticas urbanas e territoriais. Não obstante as definições genéricas introduzidas, pode constituir, em particular para os países que têm menos prática com as políticas de tutela paisagística, uma importante base de partida para uma reflexão sobre os seguintes aspetos: a tutela do património paisagístico; a qualidade dos processos de transformação urbana e territorial (que construirão as paisagens de amanhã); a qualidade paisagística nas estratégias, nos objetivos e nas ações de governação do território.

No aspeto patrimonial, recorde-se o debate em curso na UNESCO sobre a tutela dos "patrimónios urbanos históricos" (Bandarim e van Oers, 2012). Esta reflexão representa uma evolução das definições, dos princípios e das linhas orientadoras para o restauro e conservação dos bens patrimoniais que, desde 1931, marcaram a redação de numerosas "cartas": de Atenas a Veneza, de Amesterdão a Cracóvia. O tema da cidade e dos centros históricos constitui um dos aspetos mais importantes desta elaboração, que em Itália foi enriquecida também pelas reflexões da Associação nacional de centros histórico-artísticos (ANCSA) e sintetizadas nas cartas de Gubbio de 1960 e de 1990, com importantes consequências na cooperação internacional e, em particular, na América Latina (Toppetti, 2011). A "paisagem urbana histórica" nas recomendações da Unesco, apresentadas em 2011, é entendida como o resultado de uma estratificação histórica de valores, fatores culturais e naturais que ultrapassam a noção consolidada de "centro histórico" que marcou durante anos, em Itália, uma das categorias operativas da nossa prática urbanística. A definição refere-se a um contexto urbano e geográfico mais amplo, fruto de processos seculares de estratificação e de sedimentação histórica que lhe deram uma forma. Trata-se de um conceito que, segundo os especialistas que se confrontaram com esta nova locução, não substitui as práticas locais e nacionais consolidadas, mas integra-as propondo uma categoria operativa a utilizar na definição das políticas de tutela e planificação urbana e territorial. Através desta definição conceptual, a "Recomendação" pretende contribuir para a renovação dos instrumentos jurídicos, técnicos e de planificação necessários para reconhecer, catalogar e conservar os valores associáveis ao conceito de "paisagem urbana histórica". A evolução dos documentos que em Itália e a nível internacional estão a reorientar as políticas de conservação do património, cada vez mais associa a dimensão da conservação à da inovação. A conservação torna-se, neste sentido, um momento fundamental do processo de regeneração das nossas cidades. Por outras palavras, coloca-se de novo o problema da história como ponto de partida para o projeto contemporâneo que não é mais do que o percurso seguido no desenvolvimento das atividades de projeto apresentadas neste volume. História e local podem representar duas dimensões operativas de uma estratégia de desenvolvimento, nomeadamente "local", mas necessária para competir num mundo cada vez mais globalizado (Magnaghi, 2010). 
"Água como património" é um título simultaneamente evocativo e pró-ativo. Por um lado, recorda a história das cidades e as relações com a água que se estabeleceram ao longo dos séculos. Por outro interroga as formas presentes e futuras destas relações. Historicamente, a água foi um recurso para a cidade, uma fonte de energia, uma infra-estrutura de mobilidade e recetor de resíduos. Entre o século XVII e o século XVIII, os troços urbanos de muitos rios começaram a ser transformados em locais monumentais. Com a Revolução Industrial, o curso de água tornou-se uma fonte energética e infra-estrutura portuária para o transporte de mercadorias, mas transformou-se também num local de degradação e de poluição. Com a crise do modelo industrial, nos anos 1970 e 1980 do século XX, muitos espaços fluviais tornaram-se cemitérios de áreas produtivas ou infra-estruturais abandonadas, mas de seguida originaram oportunidades de requalificação. Hoje, são muitas vezes evocados como locais de redescoberta de espaços abandonados das cidades a regenerar e a transformar em espaços públicos, novas polaridades urbanas ou corredores ecológicos.

Como num palimpsesto, ao longo do tempo estes processos reescreveram a estrutura de muitos territórios e deixaram numerosos rastos. As velhas ordens territoriais foram substituídas por novas. Em alguns casos, reaproveitaram-se (ou fundaram-se) velhas estruturas ou urdiduras do solo e este processo de "estranhamento" muitas vezes descontextualizou aquilo que restava dos históricos sistemas de instalação do território. Podemos mencionar, a este propósito, a permanência de traços da centurização romana nos territórios da planície do Pó, com vista a uma urbanização difusa, ou os traços de antigas urdiduras rurais como os murs à pêche (viveiros) nas periferias da região parisiense.

Trata-se de um processo que, ao longo do tempo, modificou, alterou e apagou formas urbanas, mas que nos permite hoje redescobrir e identificar rastos, estruturas e elementos, frequentemente minimais, que são testemunhos da riqueza de relações estabelecidas entre a água e as cidades. A introdução do termo "património" neste contexto pode ser surpreendente. Porquê? Certamente devido à dimensão conservativa que o identifica. A evolução das problemáticas de salvaguarda dos bens culturais em toda a Europa foi bem entendida, ainda que diferenciada. De uma ideia de "monumento" passou-se rapidamente ao conceito de cidade e de tecido urbano menor, que reencontramos por exemplo na problemática dos "centros históricos" e, hoje, no referido conceito de "paisagem urbana histórica". O conceito de bem paisagístico, por sua vez, foi alargado para o de "paisagem cultural", que permitiu aumentar a área da tutela e da sensibilidade a âmbitos mais vastos. Na verdade, o conceito de "paisagem cultural" pode ser motivo de confusão, uma vez que a paisagem é por definição cultural, independentemente de ser bela ou desagradável. Quando o homem começou a usar a charrua, o solo passou de terra a território. De seguida, foi necessária a evolução de alguns séculos de cultura literária, pictórica e estética, chinesa e europeia, de modo a que fosse reconhecida uma dimensão estética a este processo de construção do território, transformando-o assim em paisagem (Berque, 1995). Por fim, há algumas décadas atrás atribuiu-se um valor patrimonial também aos locais de trabalho e começou-se a falar em paisagens do trabalho e arqueologia industrial. Mas, como vimos, o conceito de "património" pode ser também o ponto de partida para um projeto contemporâneo das cidades e dos territórios. Há alguns anos atrás, um eficaz slogan do Ministério da Cultura francês 
procurava afastar a desconfiança dos franceses em relação à arquitetura contemporânea, lançando a mensagem de que a arquitetura de hoje será o património de amanhã. Uma provocação eficaz que atribui a cada um de nós (intelectuais, administradores, técnicos, citadinos) responsabilidades e que carrega de significado e responsabilidade as nossas ações de transformação do território. No desenvolvimento das problemáticas e das normas (códigos, leis, regulamentos) que na Europa colocaram o problema de governar as transformações territoriais, tutelando os valores patrimoniais, paisagísticos e monumentais, cruzaram-se sempre determinados aspetos e pontos de vista:

-a relação entre inovação e conservação;

-a relação entre natureza e cultura;

-o equilíbrio entre o interesse público e privado;

-a relação entre o universal e o identitário.

No que respeita ao primeiro aspeto, a questão está em aferir se a inovação (e, portanto, o projeto contemporâneo) e a conservação (e, portanto, a tutela dos valores e lugares do passado) representam duas dimensões que convivem lado a lado sem interagir ou se, pelo contrário, podem coexistir integradas numa mesma ideia ou estratégia. Em 1990, a atualização da Carta de Gubbio colocou o tema da conservação como questão estrutural e "privilegiada" do projeto. O tema das permanências e da memória torna-se em ação de projeto, um ato criativo que contribui para o processo de transformação urbana. Para trás fica a "tábua rasa" que encontramos na Carta de Atenas, a qual nos tinha habituado a uma retórica do Movimento Moderno. O tema da enxertia do ato arquitectónico inovador num contexto ou num local formado ao longo de um processo secular de estratificação é uma reflexão que muitos autores propuseram (Choay, 2011; Gambino, 1997). Trata-se de uma relação dialéctica que não pode medir-se com a ideia de que cada território é o resultado de um processo de estratificação histórica que pode ser reescrito, como referimos a propósito do palimpsesto. É necessário conhecer bem as regras e sintaxes.

A relação entre natureza e cultura não é certamente um tema novo para quem se ocupa de cidades e de território. Hoje, em toda a Europa, há uma grande discussão sobre como restabelecer as relações entre a cidade e a natureza para se atingir o objetivo de ter uma cidade sustentável. Trata-se, na realidade, de um tema que levou ao nascimento da urbanística como disciplina necessária para sanar os males da cidade industrial. Como recorda Pierre Lavedan, a urbanística nasceu para estudar as terapias para uma cidade adoentada devido à revolução industrial. A higiene urbana representava o antídoto para curar o corpo urbano doente e, entre as medidas previstas, a introdução de zonas verdes na cidade não foi por certo secundária. Na passagem do século XIX para o XX, apareceram algumas ideias importantes de reconfiguração metropolitana através da natureza. A primeira pode ser atribuída a Frederick Law Olmsted, um dos pais da planificação paisagística que experimentou nos seus projetos o conceito de Park System, ou seja, a utilização de componentes naturais e geográficos presentes no interior e em redor da cidade, para construir uma rede interligada de espaços naturais. Em Boston, a Emerald Necklace atravessa 5 milhas da área metropolitana e esta ideia foi seguida pelo paisagista 
Jean Claude Nicolas Forestler e proposta para a reorganização da região parisiense. Mas podemos falar também dos espaços naturais utilizados como coroa, cintura e cunha em numerosas propostas de organização urbana, experimentadas nas cidades ocidentais: de Berlim a Copenhaga, de Amesterdão a Helsínquia. O verde na cidade, na aceção dupla de natureza urbana e de espaço público, é, portanto, uma aquisição recente, mas hoje a cidade já não é um organismo compacto. Ao longo do século XX, o "desejo" de urbanização, depois de ter transformado os terrenos externos mas contíguos à cidade, foi mais além e investiu-se em territórios rurais entre as cidades e as metrópoles. Estas regiões urbanizadas, que os urbanistas começaram a denominar e a descrever como uma "cidade difusa" (Indovina et al., 1990), apareceram compostas por urbanizações incoerentes. Aqui estão presentes centros históricos, periferias residenciais consolidadas, novas áreas residenciais com lotes unifamiliares, áreas artesanais e produtivas, infra-estruturas rodoviárias e zonas de campo já fragmentadas e muitas vezes urbanizadas.

A sua configuração vasta pôs em causa as habituais divisões administrativas e coloca, hoje, um problema de governação do território à escala de aglomeração. Esta condição de "ilimitação" urbana coloca questões sobre os projetos que tendem a restabelecer as relações entre cidade e natureza. Por exemplo, hoje faz sentido pensar, como se tem discutido, os projetos de revitalização como construção de um limite definido entre a cidade e o campo? Tais intervenções não são pensadas como projetos no limite, colocados nos interstícios da cidade ilimitada, onde também os campos, nos seus modos de uso, se tornaram urbanos? Neste sentido, uma reserva natural ou florestal, ou a presença de um curso de água podem assumir um duplo valor, enquanto bens naturais a tutelar mas também enquanto pontos de partida para a construção de uma nova rede de espaços naturais e para o usufruto público.

O valor que exprime o conceito de património é algo que vai para além da propriedade de uma pessoa ou de um país; deve ser de todos. Neste sentido, o património cultural é mundial e cada país tem o dever de o proteger através de um aparato jurídico e dos serviços administrativos e técnicos, de modo a gerir e aplicar as leis do setor. O art. 9 da Constituição italiana lembra que entre os princípios fundamentais de desenvolvimento do país está a cultura, a investigação científica e técnica e a tutela e salvaguarda do património histórico. O processo de desprivatização dos bens patrimoniais começou com o lluminismo e a Revolução Francesa. Formaram-se os grandes museus públicos, as grandes propriedades aristocráticas tornaram-se domínio público, com os seus grandes parques, que em muitas cidades se tornaram os principais jardins públicos.

Mas, nas últimas décadas, assistimos cada vez mais ao emergir de posições contrastantes. Se por um lado uma parte da sociedade está mais convicta do direito da sociedade a fruir dos bens culturais, por outro há uma componente social orientada para a privatização. As razões que tornam o património cultural em bem coletivo são por demais evidentes. Trata-se de bens que exprimem a história e as identidades de um país, são manifestações do engenho e da cultura expressa por um povo ou comunidade e representação de um património insubstituível para o enriquecimento cultural e a educação da coletividade. Se esta consciência estava antes associada apenas aos bens artísticos e monumentais, hoje inclui também o ambiente, o tecido urbano histórico, a paisagem e, portanto, tem influência em todos os processos de transformação urbana e territorial. 
Na ideia de património prevalece, por fim, o seu valor universal ou o facto de ser fonte e alimento das identidades locais? O tema é controverso, hoje vivemos numa sociedade globalizada na qual, para ser ator do próprio desenvolvimento, uma comunidade deve ter consciência da importância da sua própria identidade, na qual se inclui também o cruzamento extraordinário entre a história e as construções e lugares que constituem o património.

Mas esta consciência alerta-nos para as nossas responsabilidades: a sua conservação para proveito de toda a humanidade; a sua valorização, evitando identificações folclóricas ridículas e, por fim, a capacidade de governar e de gerir as transformações e as modificações dos contextos urbanos, territoriais e paisagísticos em que se encontram os bens patrimoniais. Se nem tudo pode ser património, é igualmente importante ter a consciência de que não devem existir territórios e paisagens sem qualidade. Uma qualidade a encontrar até nos elementos mínimos que compõem a estrutura de um território ou cidade, como o desenho de uma estrada ou uma boa organização dos espaços de convívio. Também a qualidade dos espaços de vida quotidiana podem, a este respeito, representar um fator de identificação local importante para o desenvolvimento de um território inserido em dinâmicas globais.

\section{Cursos de água e cidades: um património de projeto}

O tema condutor deste projeto teve em conta uma reflexão comparativa sobre o papel cultural e estrutural dos cursos de água nas estratégias e nos processos de regeneração urbana. A importância da água na configuração dos espaços urbanos é um tema que foi várias vezes objeto de estudo, de reflexões e projetos, assim como o estudo dos processos de transformação que sancionaram a sua modificação em espaços muitas vezes utilitários, simbólicos ou monumentais.

Por todo o mundo, grande parte das aglomerações urbanas cresceram ao longo ou em redor das bacias de água. Os rios, as lagoas, os deltas, os estuários e, por fim, as costas representaram o suporte geomorfológico que favoreceu a fundação e o desenvolvimento de muitas cidades. A sua localização precisa e a variedade das suas formas foram certamente condicionadas por configurações do solo para permitir espaços mais facilmente urbanizáveis, como ficou evidente em numerosos estudos de geografia (Gourou, 1973; Ortolani, 1984). De resto, como nos demonstram as civilizações potamitas, a evolução das cidades da Antiguidade e Idade Média não seria sequer concebível sem uma relação direta com um recurso fundamental desta natureza. Nos processos de aglomeração urbana, a água teve um papel fundamental na escolha da localização da cidade, assim como no desenvolvimento de culturas urbanas fortemente influenciadas pela presença da água; essencial também para o reforço do desempenho económico estratégico de uma aglomeração, com vista ao desenvolvimento de atividades comerciais e industriais e de infra-estruturas estratégicas como os portos e as auto-estradas.

Quando contemplamos cidades que cresceram sobre a água, saltam à vista as formas mais visíveis da interação entre o espaço urbano e o da água, como uma riviera ou um paredão; frequentemente admiramo-nos com a separação entre o rio e a cidade devido à construção de uma infra-estrutura. 
A relação é, na realidade, muito mais complexa. Esta é visível nas transformações da morfologia que deixaram rastos visíveis na estrutura da cidade, como uma estrada sinuosa, um tecido urbano ortogonal, ou ainda na toponomástica. Noutros casos, a água foi simplesmente ocultada e conduzida para o subsolo, como nos canais de Bolonha ou de Paris. Na antiguidade, a relação com a água era dúplice. O rio era um recurso no sentido amplo que permitia o funcionamento das cidades e o desenvolvimento da agricultura. Mas assumia também um valor simbólico e religioso, conferindo significados culturais a determinados lugares ou associando fenómenos inexplicáveis a divindades.

As problemáticas colocadas pelas cidades de água e, mais em geral, das paisagens urbanas fluviais, constituem também uma ocasião para refletir sobre as complexas relações entre cidade e hidrografia e sobre os efeitos da presença de um curso de água nos processos históricos de organização urbana, ou ainda sobre como as dinâmicas de urbanização, nesta época moderna e contemporânea, apagaram, redimensionaram e alteraram esta presença "natural" (Ercolini, 2010). A relação entre cidade e rio na história não é por certo unívoca, pois as condições geográficas e culturais e os diferentes processos históricos determinaram numerosas variantes e o desenvolvimento de casos específicos. A construção de uma cidade ao longo de um rio representa o êxito de um processo de interpretação das condições geográficas e geomorfológicas de um sítio que associa diversas exigências: uma relativa segurança hidráulica, boas condições de defesa, uma acessibilidade controlada, e a possibilidade de usar a água como recurso energético. Nas épocas posteriores à Revolução Industrial, o maior conhecimento técnico adquirido começou a tornar os modelos de aglomeração mais independentes do contexto físico-geográfico. A relação de subsistência diminuiu, muitas vezes desapareceu e as cidades começaram a domesticar o rio e a adaptá-lo a novas lógicas de funcionamento. O rio torna-se, portanto, uma área industrial, auto-estrada, infra-estrutura, área de tratamento ou descarga.

Mas o conhecimento hidráulico é um savoir faire que está intimamente ligado à evolução dos modelos e das técnicas de construção dos espaços urbanizados. O aperfeiçoamento das técnicas de infra-estruturas territoriais e urbanas e do controlo hidráulico por parte das civilizações, que foi sendo redimensionado ao longo do tempo, permitiu a construção de lugares que se tornaram monumentos ao engenho humano e, enquanto memórias, em alguns casos foram inseridos pela UNESCO na lista do património mundial da humanidade. Na Mesopotânia, diversos canais ligavam o Tigre e o Eufrates, que eram utilizados também como vias de navegação, e os imperadores persas, determinados em conquistar o Egipto, levantaram o problema da ligação entre o Nilo e o Mar Vermelho. Mas o conhecimento hidráulico não era apanágio apenas das culturas desenvolvidas à volta da bacia do Mediterrâneo ou do Médio Oriente.

No Vietname, a antiga capital Huê, declarada nos anos 1990 património mundial da humanidade, é um exemplo de uma cidade situada entre a montanha e o rio Houng, que correspondia em pleno aos princípios de aglomeração de Feng Shui. O aspeto que emerge da leitura da estrutura urbana histórica, fundada na articulação de um conjunto de locais, é o de um conhecimento extraordinário em definir o papel da água na organização urbana. A água desenvolve uma pluralidade de funções que vai da defesa, acessibilidade, irrigação, ao controlo do risco hidráulico. Huê foi uma cidade fundada no final 
do século XVII, portanto relativamente recente, mas o seu conhecimento hidráulico nasce do rico património de saberes consolidado na península indo-chinesa, com a experiência da cidade de Angkor. A capital do império, Kmer, constituía um extraordinário exemplo de planificação de um território através da predisposição de um sistema artificial de canais e bacias de água, necessários à vida urbana e ao cultivo agrícola, valendo-lhe a denominação de cidade hidráulica (Grosiler, 1979; de Bernon, 1997).

Na China, desde o terceiro século antes de Cristo, procedeu-se à construção de canais que desenvolviam a dupla função de irrigar os campos e consentir o movimento de mercadorias e pessoas. A construção do "grande canal" da China, iniciada no século $\vee$ d.C. representou uma extraordinária obra porque introduziu princípios de engenharia hidráulica depois desenvolvidos também na construção de navios europeus. O "grande canal" liga uma série de cidades de água, hoje com populações entre os 4 e os 6 milhões, de grande importância quer para a estrutura urbana histórica, crescida em simbiose com a tal rede de canais e de lagos, quer para a radicalidade dos processos de transformação urbana, em curso há algumas décadas e que levaram ao desaparecimento desse património. Entre estas cidades encontramos Hangzhou, Suzhou e Wuxi. O forte processo de crescimento demográfico e industrial por que passaram levaram a uma transformação, por vezes radical, dos espaços fluviais, sem, no entanto, apagar a sua importância e função na estrutura urbana e nas culturas locais (Xiaocong e Lamouroux 1995; Scherrer 2004).

As transformações urbanas que proporcionaram o contacto entre as cidades e os cursos de água foram marcadas por diversos ciclos económicos que condicionaram o desenvolvimento urbano e por processos de modernização sucessivos. Basta comparar as cartografias históricas de uma cidade para nos apercebermos da razão de tais transformações. Em alguns casos, o espaço fortificado das cidades medievais define uma separação nítida entre o espaço da cidade e o da água, ainda que este último seja um pulular de atividades ligadas à economia citadina. A integração entre as atividades que se desenvolvem ao longo da costa e os espaços da cidade é mais intensa quando uma cidade é atravessada por um rio. As representações de Paris, anteriores às transformações das margens do Sena num sistema de paredões, mostram-nos um frenesim ligado às várias atividades portuárias, segundo uma lógica de especialização, ao longo de todo o curso urbano do rio. Demonstra também a variedade de usos do rio, com as estações de bombagem de água como La Samaritaine, com moinhos que usavam a corrente do rio como força necessária para o seu funcionamento, com as águas que eram utilizadas como descarga para os trabalhos nos bairros artesanais erigidos ao longo do rio. A partir do século $\mathrm{XVI}$, este espaço começou a ser "artificializado" com a construção de cais em pedra, começando assim o processo de transformação urbana e monumental do troço urbano do rio que levou, em 1991, a UNESCO a considerar as margens do rio Sena património da humanidade. Paris representa neste aspeto um estudo de caso de grande interesse, na relação rica e controversa que a cidade estabeleceu com o seu rio. O século XVIII foi um século de relevantes projetos e transformações no que diz respeito aos espaços do rio. Algumas intervenções mudaram decisivamente a fisionomia desta parte da cidade, como no caso da demolição das pontes habitadas, iniciada na segunda metade do século XVIII. A importância "monumental" do rio é claramente evidenciada em numerosos projetos de 
embelezamento, com as vicissitudes do plano fantástico elaborado por Pierre Patte, após o concurso para a realização da praça dedicada a Louis XV, a chamada Place de la Concorde. Mas durante vários séculos as atividades fluviais foram verdadeiramente intensas e os vários portos eram subdivididos por categorias de mercadorias. No início do século XIX, Napoleão retomou os trabalhos no rio Sena dentro de uma estratégia para a capital e a renovação monumental ligou-se à adequação das infra-estruturas e ao saneamento higiénico. Os portos foram reorganizados e foram interditas todas as atividades de mercado que se desenvolviam quotidianamente à sua volta; o rio foi assim concebido como uma infra-estrutura de mobilidade e, sobretudo, torna-se objeto de decoração urbano (Le Moël, 1997; Lalandre, 2004).

É necessário esperar até aos séculos XVII e XVIII para que os rios comecem a assumir um papel importante na beleza urbana. Podemos referir cidades como Nantes, Bordéus, Coblença, Salzburgo e, por certo, Dresden: uma das cidades que melhor soube modelar-se à volta do rio, transformando-o num espaço cénico, como lembra Bernardo Bellotto. O século XVIII é o século dos grandes desafios da cultura iluminista. Paris, Londres e Amesterdão eram as capitais do desenvolvimento da ciência e da técnica e esta tensão de afirmação do conhecimento influenciou também os protagonistas das monarquias absolutas (Rossi Pinelli, 2009). Esta tensão manifestou-se também na vontade de submeter um contexto natural extremo à vontade política de um soberano e à supremacia da técnica. A esse propósito, a experiência mais relevante na Europa nessa época foi certamente a construção da nova capital russa de São Petersburgo por parte de Pedro o Grande, no delta do rio Neva. As vicissitudes desta cidade, assim como os numerosos projetos que estudaram a sua forma, foram objeto de várias reconstruções históricas, sobre as quais não nos iremos alongar (Lo Gatto, 1991; Antsiferov, 2003; Corboz, 2003); referimos apenas o seu carácter internacional evidenciado por Francesco Algarotti, que nas suas cartas escritas na primeira metade do século XVIII referiu o espetáculo grandioso de uma cidade - janela da Europa - na qual se cruzavam influências estilísticas italianas, francesas e holandesas.

Outro aspeto a destacar sobre a patrimonialização e valorização dos cursos de água é a rede de canais que sulcam o território de muitos países europeus. Os canais são um extraordinário exemplo de consolidação, ao longo do tempo, de um conjunto de estruturas urbanas, espaços de infra-estruturas, espaços públicos e fortificações, o que os torna hoje uma das forças das estratégias de valorização cultural e turística dos territórios atravessados por estas vias de água. A este respeito, a França é certamente um dos países mais ativos. Grande parte dos portos franceses foi construída nos rios e o grande desenvolvimento da atividade portuária, que se deu com o reforço do colonialismo, trouxe entre o século XVII e XVIII uma transformação de numerosas cidades fluviais próximas do mar, como por exemplo, Bordéus e Nantes na costa atlântica.

Se inicialmente a navegação fluvial francesa se interessou pelos cursos de água, tornando-os navegáveis (Sena, Mosella, Reno, Ródano, Garona, Loire, etc.), entre o século XVII e XVIII, procedeu-se à construção de uma rede de canais para a ligação de várias cidades do país. As razões económicas desta vasta operação de infra-estruturas são evidentes (trata-se de fazer circular mercadorias). Mas estas entraram em crise quando a concorrência da ferrovia e a função de infra-estrutura dos canais 
diminuiu progressivamente. Foi necessário esperar até à segunda metade do século XX para verificar o relançamento dos canais e a sua valorização enquanto património histórico e infra-estrutura cultural (Farinella, 2005). Segundo o historiador francês Pierre Pinon (2005), estamos perante um desenho utópico iniciado no século XVII, sonhado no século seguinte e realizado apenas parcialmente no século XIX. Mas ainda que parcialmente, no período de três séculos, o território francês foi dotado com cerca de 16.000 quilómetros de canais que hoje constituem um importante património histórico, paisagístico e turístico.

Na Europa, a construção dos canais acompanhou, inicialmente, mais do que as estradas, a infra-estruturação do continente. Os historiadores da paisagem medieval (Le Goff, 1981; Fumagalli 1988) disponibilizaram-nos eficazes descrições da reconstruída rede urbana europeia. Assim como as imensas florestas, os grandes rios marcavam a geografia do continente, enquanto as terras eram muitas vezes mais ricas em água do que em solo. A conquista de terrenos cultiváveis tornou-se subitamente um desafio ligado às urgentes exigências do solo, que se começaram a manifestar após os processos de crescimento da população e a consequente "fome de terra" que percorreu a Europa no final da Idade Média.

Giovanni Botero, em 1588, descreveu fielmente o processo de "colonização" do território europeu. No seu texto As causas da grandeza das cidades, descreveu os territórios da Flandres e da Lombardia atravessados por canais e embarcações que permitiam, desde a Idade Média, o deslocamento de mercadorias e pessoas. Trata-se de canais "feitos com arte" que representavam um eficaz sistema infra-estrutural para o transporte das mercadorias para ligar, no caso de Milão, a cidade com os lagos e os principais rios do território. A construção e adequação destas redes continuaram durante o século XVIII e influenciaram profundamente a morfologia e organização de muitas cidades, em particular na Lombardia, Emília Romana e Veneto (Cattaneo, 1999; Mioni 1976). Hoje, este sistema infra-estrutural perdeu a sua função original mas adquiriu um valor patrimonial.

São vários os aspetos que conferem valor patrimonial a um canal. Em linhas gerais, esse valor deve-se, por um lado, à qualidade intrínseca do canal como obra artesanal e, por outro, à sua valência territorial. Mais precisamente, um canal é um conjunto de obras de engenharia hidráulica que permite superar os obstáculos naturais, enquanto o seu caráter paisagístico está presente na sucessão de eclusas, casas de guardas, cais, contra-canais e plantações que definem a sua peculiaridade como objeto ou estrutura paisagística. Por fim, podemos mencionar a sua conotação urbana com uma incidência na forma, que muda de acordo com a consistência da cidade atravessada. Isto verifica-se na estrutura minimal de um cais numa pequena vila, ou na configuração, nas grandes cidades, de setores urbanos inteiros, marcados também pela atividade portuária (Farinella, 2008).

O retorno da navegação fluvial nos grandes rios, originado pelo aumento das dimensões das embarcações de transporte de mercadorias, determinou a perda de importância da rede de canais e deixou no território um património de vias de água que se tornaram, ao longo do século XX, uma importante força turística. O turismo fluvial em França foi redescoberto no início dos anos 1960 e, num espaço de três décadas, tornou-se um fenómeno que envolveu mais de 10 milhões de pessoas (Damien, 2001).

Para numerosos territórios rurais, a presença de um canal histórico significou o lançamento de projetos ligados à valorização de "identidades" territoriais fundadas na associação de diversos fatores: 
cursos de água, paisagens vinícolas, cultura gastronómica, e a presença variada de bens arquitetónicos e paisagísticos no território europeu.

Mas no decurso do século XX, as transformações operadas nos contextos fluviais comprometeram muitas vezes a riqueza ambiental, paisagística e urbana dos cursos de água. Para além do valor patrimonial e ambiental, estes possuem potencialidades ecológicas, paisagísticas e urbanas que os tornam, se devidamente reestruturados, em estruturas privilegiadas para devolver forma e significado a mais vastos sistemas de espaços abertos (urbanos, rurais, naturais) necessários para contrastar e reequilibrar o crescimento urbano e para requalificar o território. A experiência, iniciada no início dos anos 1960 na bacia industrial e mineira de Ruhr demonstra-nos como se pode transformar um território inutilizado numa paisagem cultural. É necessário agir de forma integrada na reabilitação ambiental, na recuperação paisagística e na requalificação urbana e, de resto, diversas operações iniciadas em várias cidades europeias mostram-nos os processos de regeneração dos espaços de água, sobre os quais falaremos na secção seguinte.

\section{Cursos de água e estratégias de requalificação urbana}

O debate sobre o início das cidades na Europa e nos países ocidentais gira em torno de alguns temas gerais que dizem respeito, antes de mais, à reconversão das políticas urbanas e territoriais para um desenvolvimento sustentável, de modo a transformar as cidades em ecossistemas urbanos, em lugares de biodiversidade, em paisagens culturais cada vez mais complexas.

Isto significa pensar, antes de mais, na dimensão e nos limites das cidades contemporâneas. O tema da difusão urbana (Indovina et al., 1990) está no centro das nossas reflexões desde há trinta anos para cá; no final do século passado, começou a utilizar-se o conceito de requalificação urbana (depois chamada regeneração) para reativar áreas abandonadas por atividades industriais que fecharam ou que foram deslocalizadas, ou que continham infra-estruturas viárias ou ferroviárias inutilizadas ou de excessiva dimensão. As causas do impacto da dispersão urbana no território em termos de consumo de solo agrícola foram evidenciadas, por diversas vezes, em estudos e pesquisas no território italiano e europeu (Bonora, 2013).

As políticas e as ações para a regeneração dos espaços urbanos não impediram, contudo, a progressão da urbanização do solo europeu e, de um modo particular, do italiano. É de sublinhar a importância estratégica e estrutural seguida por numerosos projetos de requalificação urbana para relançar as cidades europeias e as suas atividades económicas e sociais, em particular após a crise industrial do fim do século XX. No que respeita à cidade de água, a redefinição e extensão do conceito de espaço público e a regeneração das antigas áreas portuárias históricas, marcaram a experiência de numerosas cidades portuárias, entre as quais Lion, Bordéus, Hamburgo ou Génova.

Uma série de temas estruturais que emerge cada vez mais dos debates sobre as nossas cidades diz respeito à relação entre cidade e natureza, ou é sintetizada pela expressão "qualidade urbana". 
Mas a procura de qualidade, quando se trata dos espaços da cidade, pode assumir vários modos. Há que ter em conta as características de desempenho dos edifícios e os padrões ligados ao desempenho energético que, também por implicações diretas com o mercado da construção civil, são frequentemente enfatizadas nos debates sobre o futuro dos nossos ambientes de vida. Talvez não faça muito sentido pensar em edifícios ecologicamente sustentáveis no que diz respeito ao ciclo da água, à poupança energética ou à utilização de painéis fotovoltaicos se depois colocamos estes edifícios na lezíria de um rio ou os usamos como pretexto para a urbanização de espaços extremos como um deserto, ou para a construção de ilhas urbanas "ecologicamente sustentáveis" junto ao mar, em costas já densamente urbanizadas. A sustentabilidade é um conceito complexo e requer a integração e sinergia entre todos os componentes que estão na base do processo de construção. Falamos da cidade, com a sua estrutura de relações sociais, culturais e económicas, a sua geomorfologia, a sua história e, portanto, de um conceito que rejeita as simplificações que frequentemente reencontramos em muitas sugestões arquitetónicas divulgadas pelos meios de comunicação.

A reflexão teórico-prática respeitante às relações entre cidade e natureza, com todas as implicações problemáticas na organização e na forma da cidade, está em cada caso ligada às escolhas que várias comunidades farão respeitando acordos e protocolos internacionais relacionados com as alterações climatéricas (Kyoto), a transformação sustentável das cidades europeias (Leipzig) ou ainda a Convenção europeia sobre a paisagem, da qual falamos anteriormente. A necessidade de repensar os modelos direcionados para o crescimento urbano apareceu com mais evidência durante os anos 1980 nos países ocidentais industrializados. Nestes últimos trinta anos assistimos à crise do sistema de produção industrial herdado da revolução industrial que fez emergir um vasto património de áreas abandonadas (industriais, infra-estruturais, militares). A reconversão do aparato industrial gerou conflitos sociais relevantes e as cidades tiveram de reinventar uma base económica e um papel no mercado cada vez mais competitivo, no qual essas mesmas cidades se tornaram protagonistas de uma corrida competitiva, local e internacional, para adquirirem funções cada vez mais importantes e exclusivas. Em Itália podemos citar cidades como Génova e Turim.

Um elemento importante de tais estratégias encontra-se na redescoberta da própria identidade histórica associada frequentemente à necessidade de regenerar a enorme quantidade de locais degradados, por vezes históricos, noutros casos bem localizados no interior da cidade ou em pontos de charneira entre o centro histórico e a periferia. Esta reflexão está associada a projetos concretos que se tornaram símbolos da capacidade de governação. Hoje, apesar da crise que aflige as nossas sociedades, assistimos a uma grande atividade por parte dos governantes empenhados em importantes trabalhos de requalificação urbana, que podemos atribuir aos seguintes fatores (Portas, 1998):

1. O início de estratégias importantes e ambiciosas por parte das coletividades locais, como no caso de cidades como Lion, Hamburgo ou de regiões como Ruhr;

2. O aproveitamento de oportunidades geradas por grandes eventos como as olimpíadas ou uma exposição universal que tragam à cidade recursos importantes. Em alguns casos, os processos 
decorrentes destes eventos proporcionarão efeitos positivos na cidade também após o fim do evento (Barcelona, Turim). Noutros casos, os efeitos da requalificação da cidade são mais modestos, senão mesmo negativos, como é o caso de Sevilha;

3. Situações de catástrofe também podem gerar a requalificação da cidade, como é o caso do incêndio do Chiado em Lisboa, mas podem também provocar imobilismo ou dar lugar a processos de reconstrução desadequados, como por exemplo no terramoto de Aquila;

4. Por fim, podemos mencionar os grandes projetos imobiliários, os investimentos dos grandes grupos industriais ou das sociedades que gerem as redes de infra-estruturas. As docas londrinas, as áreas Pirelli, em Milão, ou a recuperação das áreas ferroviárias de Paris Rive-Gauche representam algumas destas intervenções que produziram êxitos por vezes contrastantes entre si.

Os cursos de água foram um dos elementos fundamentais desta longa época de requalificação urbana. Muitas vezes, o próprio nome (Emscher) ou uma particular configuração geomorfológica ou funcional (confluência, margens, portos) identificaram, também mediaticamente, o processo de transformação. Em alguns casos, estes permitiram a reorganização de áreas metropolitanas, contribuindo para a criação de redes de espaços naturais e públicos, transformando-se também em corredores ecológicos. Noutros casos, as estratégias e os projetos concentraram-se em zonas urbanas limitadas, como por exemplo uma área portuária ou uma zona industrial abandonada. Por isso, estas experiências de requalificação urbana referentes à relação entre os cursos de água e as cidades mostram-nos uma rica variedade de intervenções e de ações que oscilam entre a requalificação de um setor urbano e a construção de uma rede de corredores ecológicos ou paisagísticos: duas dimensões que podem, obviamente, coexistir. Não é fácil classificar os diferentes projetos que nas últimas décadas se dedicaram à relação entre a cidade e o rio; a causa é determinada por complexidades de situações históricas, naturais e urbanas, que estão na base destas operações. Além disso, um projeto pode muitas vezes ser avaliado sob uma multiplicidade de fatores que tornam difícil a sua classificação. Todavia, é possível encontrar semelhanças. Um primeiro grupo de experiências diz respeito às cidades que consideraram o rio como espaço público "histórico-patrimonial" a valorizar. As experiências conduzidas em Paris, Lion ou Bordéus são, neste aspeto, emblemáticas. Outras cidades como Varsóvia, Mónaco ou Leicester enfrentaram o problema da requalificação das próprias áreas urbanas através de ações para reforçar o rio como corredor natural ou como espaço a revitalizar. Um terceiro caso pode ser associado à experiência de bairros como Wasserstadt, Berlim, ou Hammerby Sjostad, Estocolmo, que utilizaram uma bacia de água no interior da área metropolitana para receber expansões urbanas de alta qualidade ambiental. Por fim, devemos assinalar o caso mais frequente de recuperação das áreas portuárias. Todas as grandes cidades fluviais europeias, de Londres a Hamburgo, de Bilbau a Nantes, defrontaram-se com problemáticas deste tipo.

Ainda no âmbito dos processos de infra-estruturação de um território, podemos referir também o exemplo da valorização dos canais históricos. Também aqui, as operações desta natureza pretendem 
relançar um determinado território ou cidade dando importância a elementos historicamente relevantes mas esquecidos, e em muitos casos não incluídos nos processos de modernização urbana e territorial do segundo pós-guerra. As experiências a referir são várias, como é o caso das embarcações lombardas e milanesas, a reabertura das embarcações de Bolonha, os territórios da antiga Flandres, como a cidade de Bruges, ou ainda os projetos a decorrerem em Lille e a experiência de Birmingham.

A França, pela extensão da sua rede para a qualidade da paisagem dos canais, representa um caso extraordinário de valorização territorial que associou qualidade da paisagem, fruição quotidiana e local destes espaços, e promoção turística ligada também à sua tradição histórica, gastronómica e vinícola. Uma situação diferente, mas igualmente emblemática, que demonstra as potencialidades que podem derivar da associação entre políticas de paisagem e processos de requalificação urbana é verificável na Alemanha. Trata-se do Ruhr, um território à procura de identidade que referimos anteriormente. É uma antiga bacia mineira rica em carvão e ferro que no início do século XIX passou por um intenso processo de industrialização caracterizado pela construção de ferrovias, estradas e, sobretudo, canais. A reestruturação industrial, iniciada a partir dos anos 1960, e a sua valorização paisagística iniciada vinte anos depois, transformaram esse território numa das paisagens culturais mais dinâmicas em termos de reinvenção e de requalificação urbana e paisagística mas também de governação, como testemunha a experiência de Emscher Park.

Referimos experiências que demonstram que a reabilitação das cidades e das paisagens precisa de uma visão integrada dos problemas e das relações entre a cidade, a paisagem, a natureza, a cultura e a economia. A ecologia urbana, a este propósito, é importante. A noção de ecossistema está intimamente associada às interações que se libertam entre os seus elementos estruturais. Dependem principalmente das relações que se estabelecem entre a parte e o todo, como salienta Edgar Morin (1992) e é na qualidade destas relações que reencontramos a complexidade e a organização de um sistema. Se um curso de água pode ser associado a um ecossistema composto por espaços urbanos rurais e naturais, estes devem tornar-se elementos interdependentes, ainda que dotados de uma própria especificidade.

O desafio do projeto contemporâneo é pensar e gerir a complexidade e as ações, possíveis e necessárias, que devem ser compatíveis com a sustentabilidade e com uma abordagem multidisciplinar. Questões como a qualidade da água, as relações com a cidade existente, as identidades históricas e a heterogeneidade devem ser associadas a estratégias de médio e longo prazo, em que se proceda à condução de ações de projeto fundadas numa renovada e mais avançada parceria entre o público e o privado, e que incluam o envolvimento real e participativo das comunidades locais. Sob este ponto de vista, a União Europeia, com os programas de intercâmbio, ajuda, cooperação e solidariedade representa uma oportunidade de troca e partilha de experiências. A regeneração dos espaços urbanos requer um trabalho constante fundado na junção de diversas competências profissionais e no contacto constante com os diversos interessados. Hoje, fazer parte de uma rede que partilha problemáticas, temas e experiências constitui uma oportunidade importante para qualquer cidade, pois é possível encontrar soluções adaptáveis às necessidades específicas. 


\section{Referências bibliográficas}

Antsiferov, N. P. (2003), L'Ame de Saint-Pétersbourg. Paris, B. Giovanangeli.

Bandarin, F. e van Oers, R. (2012), The Historic Urban Landscape: Managing Heritage in an Urban Century. Chichester, JOHN WILEY \& SONS INC.

Berque, A. (1995), Les raisons du paysage. De la Chine antique aux environnements de synthèse. Paris, Hazan.

Bonora, P. (Orgs.) (2013), Atlante del consumo di suolo. Per un progetto di città metropolitana. Bolonha, Baskerville.

Cattaneo, R. (1999), Metodo e strumenti della nuova programmazione regionale. Roma, Laterza.

Chastel, A. (2012), Architecture \& patrimone. Paris, Éditions du Patrimoine.

ChoAy, F. (1993), L'Allégorie du patrimoine. PARIS, Le Seuil.

ChoAy, F. (2011), LA TERRE QUI MEURT. PARIS FAYARD.

Corboz, A. (2003), Deux Capitales françaises. Saint-Pétersbourg et Washington. Paris, Infolio éditions.

Damien, M. M. (2001), Le tourisme fluvial. PARIS, PUF - Que SAIS-JE?

de Bernon, O. (1997), Note sur l'hydraulique théocratique AngKorienne. Bulletin de l'ECole FrançaISE D'EXTRÊME, 84, P. $340-348$.

Ercolini, M. (2010), Cultura dell'acqua e progettazione paesaggistica. Roma, Gangemi.

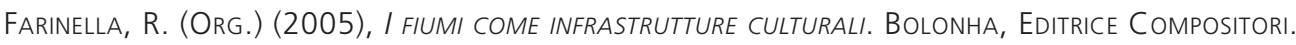

Farinella, R. e Ronconi, M. (Orgs.) (2008), Territorio, fiumi, Città. Esperienze di riqualificazione in Italia. Sant'Arcangelo DI ROMAgna, MaggiOLI.

Fumagalli, V. (1988), La pietra viva. Città e natura nel Medioevo. Bolonha, il Mulino.

Gambino, R. (1997), Conservare Innovare. Paesaggio, Ambiente, Territorio. Torino, Utet.

Gourou, P. (1973), Pour une géographie humaine. Paris, Flammarion.

Groslier, B. P. (1979), LA CITÉ hydRAULIQUe ANGKORIENNE: EXPLOITATION OU SUREXPLOITATION DU SOL ? BULLETIN DE L'ECOLE FRANÇAISE D'EXTRÊME-ORIENT, 66(1), P. 161-202.

INDOVINA, F. ET AL. (1990), LA CITTÀ DIFFUSA. VENEZA, DAEST-IUAV.

Lalandre, A. (2004), Histoire des ports de Paris et de l'lle de France. Rennes, Éditions Ouest-France.

LE GofF, J. (1981), LA CIVILTÀ DELL'OCCIDENTE MEDIEVAlE. TURIM, EINAUdi.

Le Moël, M. (1997), L'urbanisme parisien au sièCle des Lumières. PARIS, Action Artistique de la Ville de Paris.

lo Gatto, E. (1991), Il mito di Pietroburgo. Milão, Feltrinelli.

Magnaghi, A. (2010), Il progetto locale. Turim, Bollati Boringhieri.

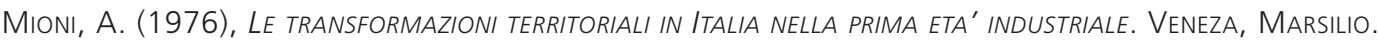

Morin, E. (1992), Il metodo. Ordine, disordine, organizzazione. Milão, Feltrinelli.

Ortolani, M. (1984), Geografia delle Sedı. PÁdova, Piccin.

Pinon, P. (2005), Patrimoine fluvial. Canaux et Rivières navigables. Paris, Nouvelles éditions Scala.

Portas, N. (1998), L'emergenza del progetto urbano. Urbanística, N.110, pp. 51-60.

Rossi Pinelli, O. (2009), Le arti nel Settecento europeo. Turim, EINAudi.

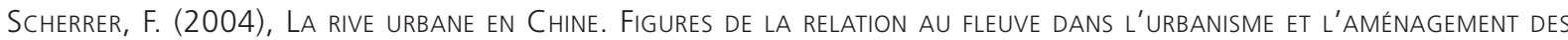
Villes du bas Yangzi. GÉocarrefour [Le Yangzi et le RhÔne, Regard Croisés]. Lyon, 79(1), 41-48.

Settis, S. (2010), Paesaggio Costituzione Cemento. Turim, Einaudi.

Xiaocong, L. e Lamouroux, C. (1995), La formation de réseaux urbains dans la Chine du XIE SIĖCLE. BULletin DE L'ECOLE FRANÇAISE D'EXTREME-ORIENT, 82(1), P. 185 - 199

Toppetti, F. (Org.) (2012), Paesaggi e città storica. TeOrie e politiche del progetto. Florença, Alinea. 


\section{VIAS DE ÁGUA, PAISAGENS: A NOÇÃO DE PATRIMÓNIO FLUVIAL}

PIERRE PEYRET 


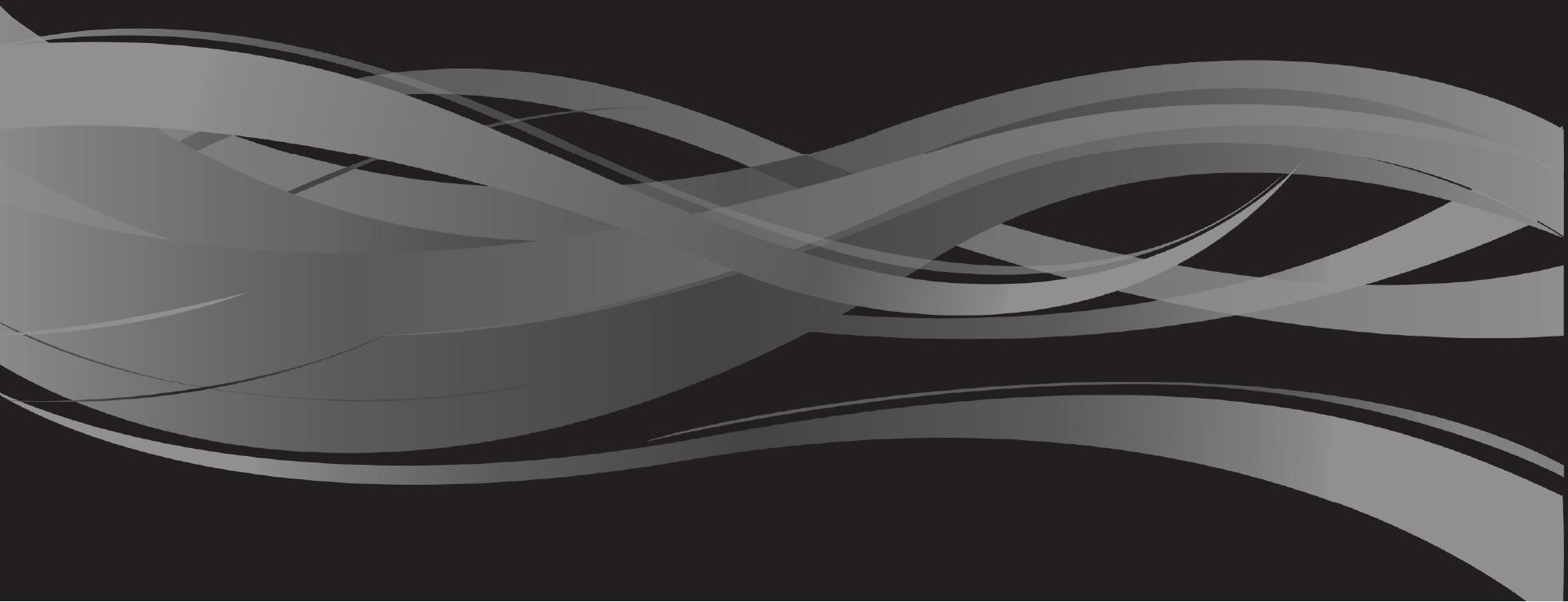


Evocar as vias de água é, antes de mais, evocar a diversidade. Espaços fechados, espaços abertos, planos de água interiores, planos de água naturais ou artificiais, águas estagnadas, águas vivas, livres.

O rio, a ribeira, a torrente, o riacho, o canal, ou melhor dizendo os canais: de irrigação, de junção, laterais. É evocar ao mesmo tempo a substância líquida e a sua antropização, "a natureza" e o artificial; é evocar vetores de um recurso vital, meios frágeis, um formidável reservatório de vida vegetal e animal, o próprio símbolo do movimento, uma massa que, devido a um desnível, corre num leito de montante para jusante. Aceleração, abrandamento, lentidão e impetuosidade.

É evocar também os diversos usos; diversos ao longo do tempo. É evocar ainda significados plurais e diversos. O vertical e o horizontal, um espaço de três dimensões. É evocar paisagens; é evocar técnicas de dominação hidráulica, um motor económico. É a tinta e o pincel. É a ambivalência entre prazer e necessidade. Mística, utilitária, onírica, ameaçadora. Atração, repulsa. É a ruptura e a sutura, o obstáculo e a ligação. Curva, contra-curva, retidão. A água e a sua margem, a linearidade e a transversalidade.

É evocar a longa cavalgada da água agregando-se à água e desagregando-se do cascalho. São dois corpos físicos, a água e a terra, coniventes e antagónicos, dois códigos controlados de forma diferente pela duplicidade da lei, estática para um e dinâmica para outro, duas formas de sujeição, duas incompatibilidades eternas, a água e a sua orla. É um trabalho de ligação perpétua, a água e a sua cercadura procurando as suas unidades, colmatando-se; um sistema binário susceptível de distorções, em que cada elemento procura constantemente libertar-se do outro. A água traz em si a imagem mais espetacular, a imagem do movimento à procura da sua libertação. É a terra que opera a repressão que enquadra, enquanto a água dá forma lutando contra o centralizado, o geometrizável, assombrado por uma axiomática da fuga e da expansão.

É a axiomática da fuga e da expansão contra a repressão; é a imobilidade e a mobilidade que se enfrentam; é a transparência e a opacidade. A água transparente, a água espelho. São dois elementos essenciais mas que tudo parece separar mas é também a complementaridade e a interdependência, o campo e o contra campo.

Dois corpos monárquicos, constituídos. É a linha de separação entre a norma e os seus desvios.

São tecnologias que tratam estes corpos como máquinas, técnicas agenciadas com vista a um rendimento que sistematize e racionalize as suas formas fundamentais. É evocar o estabelecimento das comunidades humanas, o eixo estruturante dos vales, o eixo de desenvolvimento de atividades, um eixo de descoberta. Realidades físicas, princípios históricos, caminhos de filiação, escritura do tempo. São diferentes espaços, dimensões, escalas. Noções de contextos, contextos físicos, contextos de enunciação, práticas, hábitos, culturas locais peculiares, específicas, zonas de intervenção, por vezes limitadas mas sempre complexas, é uma forma de definição sujeita ao relativismo, é uma pluralidade de discursos que têm dificuldades de convergir.

\section{Paisagens - A visão europeia da paisagem}

A Convenção Europeia da Paisagem adotada em Florença, em Itália, a 20 de outubro de 2000, tem por objetivo promover a proteção, a gestão e o ordenamento das paisagens europeias e organizar 
a cooperação europeia neste domínio. Considerada como a primeira convenção do desenvolvimento sustentável, representa um importante contributo na operacionalização dos objetivos do Conselho da Europa: trata-se de favorecer a qualidade de vida e o bem estar individual e social tendo em conta os valores paisagísticos, naturais e culturais.

Os Estados membros da Organização signatários da Convenção declararam-se preocupados em "chegar a um desenvolvimento sustentável fundado no equilíbrio harmonioso entre as necessidades sociais, a economia e o ambiente". A dimensão cultural ocupa igualmente um lugar central.

Instrumento inovador, a Convenção representa um tratado internacional exclusivamente dedicado ao conjunto da Paisagem dos Estados Europeus, considerado como espaço de vida dos indivíduos e das sociedades. Cada uma das partes contratante se compromete a reconhecer juridicamente a paisagem enquanto componente essencial do quadro de vida das populações, expressão da diversidade do seu património comum cultural e natural, e fundamento da sua identidade.

A Convenção Europeia da Paisagem define a paisagem do seguinte modo: a paisagem é "uma parte de território tal como é percecionada pelas populações, cujo caráter resulta da ação de fatores naturais e/ou humanos e das suas interelações". É salientado que a política da paisagem é "a formulação, pelas autoridades públicas competentes, dos princípios gerais, das estratégias e das orientações que permitem a adoção de medidas particulares com vista à projeção, gestão e ordenamento da paisagem".

Encontramos aqui ao mesmo tempo o impacto da corrente fenomenológica e da abordagem sistémica.

Madame Maguelone Déjeant Pons, Chefe de Divisão do património cultural da paisagem e do ordenamento do território no Conselho da Europa, lembrava aliás, na sua intervenção sobre a paisagem fluvial por ocasião do $7^{\circ}$ Colóquio Fluvial Europeu do Sul, em Sevilha, que:

"as bacias fluviais e os vales aluviais representam um desafio específico para o ordenamento do território porque estão concentrados em bandas de território relativamente estreitas caracterizadas simultaneamente por elementos naturais importantes e de grande valor e por atividades humanas diversas".

Salienta ainda que "se reconhece tratar-se frequentemente de paisagens que tomaram forma ao longo dos séculos e detêm um potencial económico e ecológico considerável".

Uma das características da paisagem é pois o seu aspeto construtivo evolutivo, orientando a sua compreensão em função da sua relação com a história social, implicando tensão e, por vezes, mesmo contradição. A paisagem é ao mesmo tempo condicionada pela sua natureza inicial que determina mais ou menos uma forma de autonomia da sua forma e a sua imbricação com a história social que deu origem a transformações. É um tempo não uniforme, ligado a vidas, com termos e descontinuidades, um tempo humanizado. A paisagem possui a sua própria dinâmica; dinâmica essa ligada à sua transformação e aos valores do território com o qual está relacionada. As múltiplas atualizações da sua evolução.

Deve portanto apreender-se a paisagem de acordo com o seu duplo valor: valor intrínseco e valor extrínseco. A outra característica é a sua espacialidade, a entidade paisagística. Característica que se refere não apenas à profundidade do campo visual, ao seu limite topográfico mas também ao modelo 
antropológico através da teoria de quem olha como construção social, gerando a relação materialidade/ cultura, na qual podemos reconhecer a oposição, a contradição.

São ao mesmo tempo características de representações e de experiências de territórios, relações da estética e do utilitarismo. A conciliação da natureza e da vida realizou-se na paisagem através das representações geradas pelas dinâmicas económicas e pelas práticas sociais. Ao mesmo tempo materialidade e imaterialidade. Ao estabelecer a relação da paisagem com os usos que dela se fazem, a imaterialidade, as dimensões imateriais do património adquirem a sua dimensão material: trama urbana, património imobiliário.

\section{A noção de património fluvial}

Definir o que está englobado na noção de património fluvial implica, antes de mais, tomar como primeira referência a Convenção do Património Mundial que, no artigo 1, define um património cultural como sendo "obras do homem ou obras conjugadas do homem e da natureza tais como zonas, incluindo sítios arqueológicos, que possuem valores universais excecionais do ponto de vista histórico, estético, etnológico ou antropológico.".

Herveline Delhumeau, assessora para o Património Marítimo e Fluvial do Ministério da Cultura e da Communicação francês salienta que "a identidade do domínio fluvial é um conjunto cultural coerente, de montante a jusante, indissociável de todos os aspetos patrimoniais que o caracterizam: património natural e cultural, material, imobiliário, mobiliário mas também imaterial".

Daí resulta, pelo menos, que as paisagens fluviais podem ser definidas não apenas à escala do rio, mas antes à escala do vale da via de água, o talvegue dos geógrafos, quer se trate de um rio, de uma ribeira, de um canal, de um canal de junção ..., a escala na qual o rio ou o canal intervieram, em vez de estabelecer um parcelamento de facto ligado ao campo visual ou a dimensões administrativas ou políticas locais.

Os cursos de água foram elementos estruturantes de todas as paisagens, dos eixos vivos cuja inscrição no espaço é sempre forte.

E isso pode ser ainda mais significativo no caso de um canal, o corredor do canal constitui um conjunto coerente embora secante no sentido geográfico: a via navegável e o terreno de reserva do canal formam uma espinha dorsal ao longo da qual foram implantadas e evoluíram numerosas atividades humanas, industriais.

Estas duas componentes são indissociáveis e essenciais para a compreensão da noção de paisagem fluvial.

A paisagem fluvial pode ser considerada como um espaço de água, um espaço ligado à água inscrito numa duração temporal que tem origem na geografia física de um lugar, de um sítio, mas cuja apropriação pelo ser humano, ou mesmo a conquista desse espaço a uma dada escala, transformou esse espaço físico para nele construir o seu lugar de vida, o seu quadro de vida, o seu quotidiano. 
De um certo modo, o espaço tornou-se testemunho das vivências do ser humano, um elemento significante da sua história. É um lugar de inscrição do passado, das práticas, dos hábitos ligados aos seres vivos marcados na matéria, no conjunto dos elementos naturais.

É uma espécie de estratificação socioeconómica de um lugar físico inicial.

A noção de paisagem implica uma diversidade dos campos disciplinares (geografia, naturalista, agronomia, história, arquitetura, urbanismo) que, para lá das formas visíveis, permitem compreender a diversidade e a unidade, de entender a complexidade: trata-se de transdisciplinaridade mais do que de multidisciplinaridade ou interdisciplinaridade.

\section{Cidades de água e paisagens fluviais}

Qualquer que seja a implantação das cidades molhadas: cidades vaus, cidades porto, cidades instaladas em pontos de rutura da navegação interior ..., as cidades antigas organizaram-se em relação aos cursos de água, à presença da água, sede de uma atividade intensa, as ruas estabeleceram-se perpendicularmente às margens, os principais mercados desenvolveram-se frequentemente à beira, a bordo dos batéis. Mas o rio na cidade é também os banhos públicos, os lavadouros, os bebedouros, os moinhos naves, a pesca, o passeio, os jogos e as festas na água.

A transformação da fisionomia das paisagens hidráulicas urbanas ilustra perfeitamente a evolução do uso da água ligada às múltiplas reconversões e evoluções sucessivas, desde as adaptações antigas até às atividades industriais e às técnicas de produção.

A via de água era um bem precioso útil como elemento físico necessário, entre outras coisas, para a lavagem e desengurdoramento das lãs e dos couros, ao tingimento de peças de tecido, ao branqueamento de telas.... Era útil como fonte de energia, acionando os moinhos, as fábricas de fiação ou as fábricas hidráulicas, útil como meio de navegação de madeiras flutuadas, de navios para transporte de mercadorias, de matérias primas, de produtos industriais, de pessoas. A via de água desempenhou um papel no fornecimento de água às cidades (estações elevatórias), na irrigação de terrenos agrícolas que alimentavam essas mesmas cidades, assegurando os recursos haliêuticos. Todas estas práticas são, a maior parte das vezes, antagónicas. A fisionomia das paisagens hidráulicas vai evoluir segundo a evolução das relações de força entre os diversos utilizadores, o que hoje denominamos de conflitos de uso, a luta pela sua apropriação, os diferentes usos inscrevem-se na forma urbana.

Esta herança da presença da água na cidade, esta estratificação da evolução dos usos releva frequentemente mais do património urbano do que do património arquitetónico.

Os edifícios raramente têm ou não têm de todo uma linguagem arquitetónica que os distingue dos outros edifícios. Pelo contrário, a trama parcelar, a escala do espaço público, o cruzamento das ruas e dos braços de rios ou de canais - isto é, a expressão física dos usos, dos direitos de água, dos acessos à água muitas vezes dificilmente adquiridos pelo utente ou proprietário ribeirinho - materializa com frequência as raízes profundas da identidade urbana das cidades de água. 
A adaptação que as realizou já não se exprime no presente, são adaptações desafetadas.

O quadro do projeto define uma espacialidade confinada ao urbano. Sem no entanto decidir se existe uma experiência da água irredutível ligada à cidade, fica claro que existe um laço muito forte entre vários aspetos: a água enquanto património, a água enquanto componente da paisagem urbana, a água como forma de divertimento, presença da água enquanto uso e um lugar específico, a cidade, quer se lhe atribua um estatuto teórico ou não.

Existe na água como património da cidade uma realidade temporal absolutamente fundamental, mesmo quando as distensões temporais de usos são por vezes consideráveis. Foi a estrutura de uso que impôs um certo tipo de qualificação e que produz as formas de continuidade plural e polissémica, associando valores tradicionais às ideias de natureza, património construído, identidade local, quadro de vida, desenvolvimento económico.

É também, por vezes, uma utilização de algo que pertence à natureza num quadro que tende, no fim de contas, para o instrumental.

É ainda necessário integrar a questão dos lugares. É evidente que o desaparecimento dos usos tradicionais da água define uma nova periodização que é preciso ter em conta e que corresponde a um novo tipo de formatação, visto que a água como património é um instrumento de formatação, uma prática um pouco indecisa entre valores tradicionais e preocupações contemporâneas de qualidade de vida em que ela serve de linha de triagem. Temos ainda a inclusão da água na requalificação da paisagem urbana, paisagem essa que se constitui como lugar de exposição, toda uma série de transformações extremamente importantes e entre elas esta difusão de formas da água móvel em água artificialmente móvel, em água estagnada e, por vezes, em água revolta.

O desafio colocado pela água na cidade é o de encontrar um modo de concordância entre todas estas transformações, se não quisermos cair nos esquemas do tipo triunfo e morte da água viva, estetização ou anestetização ...

O trabalho sobre a noção de bem material e imaterial coloca a questão de pensar as formas da apropriação cultural.

Partilha de novos usos que geram apropriação e noções de cultura. Tudo começa com o facto de se considerar ora a existência de uma única ou de várias culturas urbanas, o que implica noções de fronteiras mais ou menos definidas, ora a formação de uma nova cultura mediante a integração de uma série de formas e procedimentos.

A problemática consiste em definir uma especificidade das cidades molhadas e de fazer valer essa especificidade porque um referenciamento não é uma identidade.

\section{A reabilitação}

A reabilitação subentende a proteção da característica da espacialidade da paisagem que deve incidir sobre a imaterialidade dos lugares, enquanto que a proteção das representações engendradas 
por uma dinâmica económica e por práticas sociais incide sobre a sua dimensão material, trama urbana, património imobiliário.

Os aspetos atuais dos bairros com relação à via de água hipotecam a conservação da trama das ruas e do tecido urbano. É ainda importante lembrar que o valor patrimonial de um bem imobiliário também se encontra na relação das pessoas com o lugar (os usos, por exemplo) ou ainda no aspeto afetivo ou simbólico que a população tem com o lugar. O modo traumático da destruição já não é habitual, como também já não faz sentido a preservação absoluta, reenviando para medidas normativas que tinham como consequência fixar um território no tempo. A noção atual inscreve-se antes na proteção ou valorização deixando esses patrimónios evoluir no interior de um quadro capaz de impedir as mutações irreversíveis da sua identidade. O centro desta proteção é a manutenção dos usos que asseguram a expressão reconhecida dos lugares, estando esses usos geralmente ligados a um tipo de economia, manutenção que está na origem da expressão cultural e social dessa paisagem. O facto de relacionar a paisagem fluvial com os usos interpela diretamente a imaterialidade dos lugares. Nesse sentido, a paisagem fluvial associa-se em parte às dimensões imateriais do património.

A persistência fantasma, o modo dessincronizado que essa paisagem inventa a partir das sobrevivências de formas antigas, mantem, ao mesmo tempo que empreende, uma criação ancorada em diferentes tempos. Falar da água como património é ler a água em todas as suas dimensões.

Falar de paisagem fluvial é admitir também a ideia de olhar para as margens a partir da água, o que equivale, mais uma vez, a uma abordagem histórica, dado que numerosos territórios foram descobertos graças à via de água enquanto suporte à deslocação. Aceitar esta ideia significa não se fechar na abordagem conhecida que consiste em apreender a água a partir da terra, aceitando ao mesmo tempo o contra campo da "imersão", o que pressupõe que se trata de um olhar forçosamente diferente.

Um ângulo de abordagem limitado, um fragmento extraído, subtraído à sua realidade: uma pausa ou um intervalo azul ou verde na mineralidade da cidade tornam-se insignificantes, enquanto que uma pausa apreendida, vivida do interior e não como adereço, torna-se significante.

Trata-se de conhecer a via de água pelo seu timbre, pela sua corrente, pelas suas profundezas, pelas suas cheias e pelos seus limites. É a outra vertente das coisas; é, na realidade, habitar a água como se habita as margens, não apenas pelo sentido de se alojar mas também pela possibilidade de se manter numa superfície diferente e apreender a cidade a partir da água, um campo bidirecional que permite ver para além da margem que fica em frente. Trata-se de substituir uma visão horizontal por uma visão vertical ou uma abordagem vertical, um grau de comprometimento que toma em consideração a existência da água na cidade. É aceitar que a água não está confinada a um espaço fechado, aceitar as suas virtudes e as suas variações. Iniciar uma reflexão sobre a água como património ligado ao urbano só pode levar a valorizar os méritos da água, aceitando que essa água não é frígida, distante, intocável, pois isso seria reduzir a água a um papel decorativo, a um objeto instrumentalizado, um simples valor estético passageiro. Ora, uma abordagem séria implica que a água deve ser viva e devemos aceitá-la como matéria viva, compreender a sua cor mutante, 
entrever os seus movimentos, estabelecer uma coabitação prolongada, levando em conta as suas realidades profundas, intrínsecas.

Obra única no seu género, obra global na qual se inscreveriam com naturalidade várias animações, várias ações cada uma delas em lugar de destaque, cada uma constituindo uma parte de um conjunto significativo e equilibrado, espaço harmónico como sugere Fourrier.

Trata-se de adotar uma reflexão em que o rio não é apenas visto como um valor ou como tendo uma função cognitiva.

Parece certamente legítimo debater e tentar avaliar a plausibilidade dos laços que poderiam unir o rio e a cidade. Já não se trata de desconstruir nem de evocar as brumas inefáveis do tempo mas antes de tentar reconstruir a criação, de reconstruir a relação a partir dos fragmentos ainda dispersos.

Qualquer reflexão deve ser tomada não como um ponto de chegada mas como uma proposta a desenvolver, uma pesquisa que se faz aceitando que está sujeita a um constante devir evolutivo.

A palavra compreender, cuja raiz clássica se encontra no latim comprendere, termo resultante da síncope da palavra latina comprehendere, cum (com) e prehender (agarrar), de acordo com o dicionário Littré, possui o sentido de apreender em conjunto fisicamente. A disjunção que leva a conceber a água associada ao prazer de contemplar, de se distrair do quotidiano, ao descanso, ao bem-estar, à humanização da vida, ao ganho de um complemento de felicidade, é uma abordagem que não permite reunir o que a experiência proposta dissocia.

Ao mesmo tempo, captação e reflexão global autêntica, compreensão da parte pelo todo e do todo pela parte. Trata-se de aceder ao sentido e não de adquirir nem de atribuir um sentido. É preciso tratar a história, o lugar, a via de água, alternando entre a representação do real e representação das ideias.

É tanto a identificação dos detalhes significantes como a perceção das relações globais.

É tomar em consideração a distinção de múltiplos níveis de integração hierárquicos encaixados uns nos outros aos quais se ligam de modo causal as funções definidas, uma combinatória da estrutura e da função.

A transição de um uso, de um nível de organização para outro, encontra a sua solução nos múltiplos processos de evolução imbricados uns nos outros, tanto no espaço como no tempo.

Refletir sobre a posição da água na cidade é aceitar a ideia de um movimento de abertura baseado no enriquecimento dos reportórios: reportório da água e reportório da cidade no que se refere aos contactos entre ambas as entidades, reportórios especializados ou não.

Um dos meios para levar a cabo esta tarefa passa talvez por reconstruir uma função hierarquicamente mais elevada a partir dos elementos e determinar o modo como esses mesmos elementos interagem entre eles para definir, para aceder a uma verdadeira função emergente. É uma nova inscrição. Inscrição que permite investir em todas as promessas que o testemunho do passado, realidade física e simbólica, permitirá realizar.

Trata-se de colocar nesta abordagem todo o património reunido das práticas, de entender este conjunto como um receptáculo: a cidade de água da qual um conjunto de propriedades seria 
o conteúdo. O património age sobre si próprio; se não sobre o seu ser, age pelo menos sobre o seu desenvolvimento. É o instante real e a duração pensada, o conceito e a construção.

Entender a água como património é talvez conceber o património como um ato restituído à sua novidade. É pois o ato de captar este estado no seu crescimento para o captar na sua essência. Entender a água como património é também, pelo seu incremento de sucesso, promover a síntese da novidade e do traço/rasto. 


\section{OS USOS SOCIAIS DOS RIOS}

PAULO PEIXOTO 


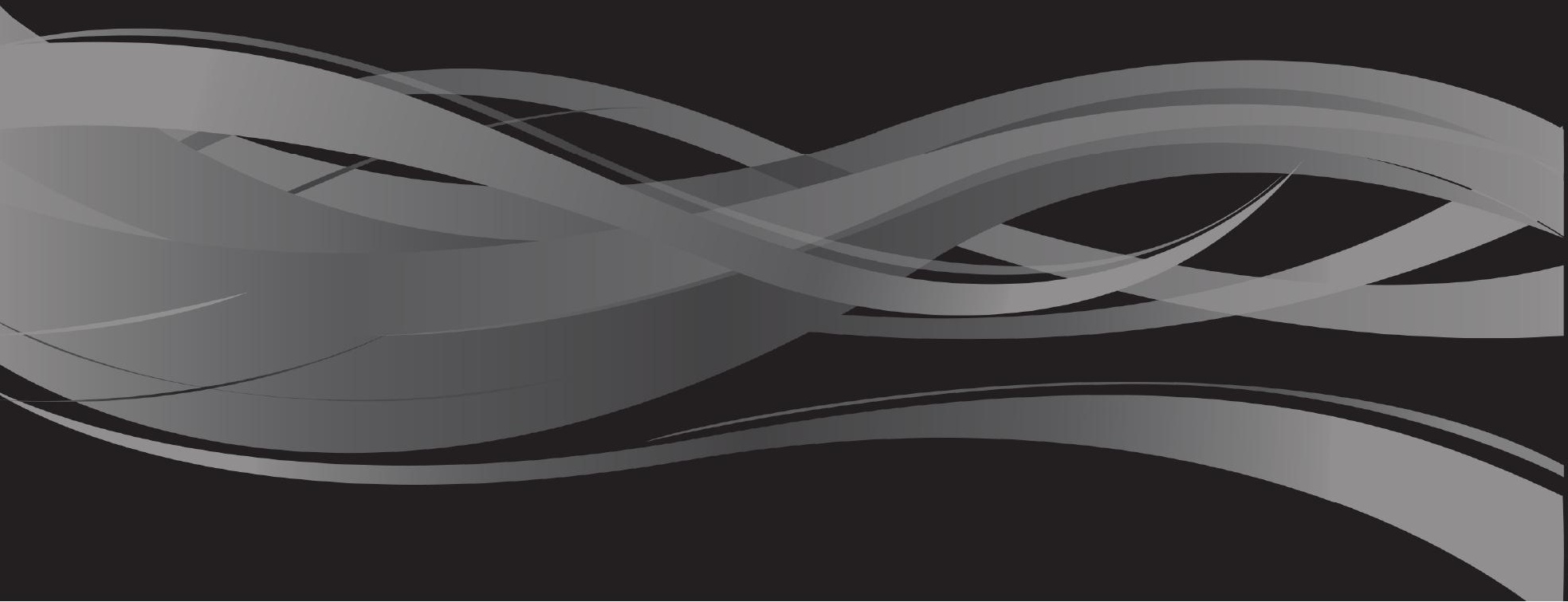




\section{NASCENTE}

E se os rios nascessem no mar? Poder-se-ia contar a história dos rios ao contrário, enfatizando o seu caráter natural ou selvagem em vez de os revelarmos enquanto produtos da intervenção humana? A questão sociologicamente relevante é a de saber até que ponto se pode reverter a situação catastrófica a que muitos rios chegaram em virtude dos usos sociais que foram preenchendo ao longo da sua história. Para muitos autores, que lamentam a excessiva intervenção humana nos rios, e que se referem expressivamente à "vida e morte dos rios", valeria a pena inverter a história dos rios de modo a evitar que tivessem chegado ao estado atual. Mas, para esses autores, parece não ser possível uma reversão aceitável. Outros autores exaltam a transformação dos rios ao longo dos séculos, enfatizando que essa transformação permite dar conta que a relação humanidade/natureza e tecnologia/ambiente são um continuum de um mesmo assinalável processo civilizacional. A verdade é que, ao longo dos séculos que nos antecederam, os rios sofreram transformações profundas nos seus usos sociais e económicos. Christof Mauch e Thomas Zeller, para demonstrarem que a ascensão das civilizações sempre esteve ligada ao modo bem sucedido como geriram a água, citam Lewis Mumford para lembrar que "todas as grandes culturas históricas ... fluíram através do movimento dos homens, das instituições, das invenções e das mercadorias ao longo das autoestradas naturais de um grande rio" (Mauch e Zeller, 2008: 1)

\section{Os rios - um fator civilizacional}

As grandes cidades das civilizações antigas situavam-se nas margens dos rios. Entre outras, poderiamos destacar: Babilónia e Ur (no rio Eufrates), Ninive (no rio Tigre), Mohenjo Daro (no rio Indo), Tebas e Mênfis (no rio Nilo). O mesmo se pode dizer para as comunidades pré-colombianas na América central, ou para as bacias hidrográficas da Indía e da China. O curso do rio Amarelo (Huang He) e o curso do rio Azul (Yangtzé) concentram, desde há séculos, grande parte da história, da cultura e da economia chinesas. O chamado Crescente Fértil, delimitado pelos rios Jordão, Eufrates, Tigre e Nilo, aglomera as cidades mais antigas de que há memória, assumindo o estatuto de 'berço da civilização humana' (Schneider, s. d.). Foi aí que, com a invenção da agricultura, as dinâmicas de sedentarização se iniciaram e que o processo civilizacional ganhou um novo rumo.

A invenção da economia agrícola, que simboliza a existência da propriedade privada, ora é vista como tendo sido uma benção, ora é vista como a tragédia da civilização humana. Independentemente das vantagens e das desvantagens da substituição do nomadismo baseado na caça e na pastorícia (questão que hoje está filosoficamente ultrapassada), é inegável que a agricultura foi o principal fator de sedentarização e que os rios foram determinantes no estabelecimento e na evolução da economia agrícola. Sendo evidente que a sedentarização, no modo e na velocidade com que evoluiu, trouxe novos desafios e novos riscos à humanidade, constituindo um marco civilizacional irreversível. A invenção da agricultura no Crescente Fértil não tem só a ver com técnicas de cultivar 
a terra, nem corresponde apenas ao salto civilizacional que liberta a humanidade dos ritmos e das disponibilidades da natureza. Corresponde também ao desenvolvimento das formas de organização social que marcam o nosso processo civilizacional; designadamente a divisão social do trabalho, a formatação das trocas comerciais e o progresso científico e técnico que alastra a todas as atividades humanas e áreas do social.

Muitas das dinâmicas sociais que aparecem funcional e simbolicamente associadas aos rios têm a sua origem na invenção da agricultura e na evolução do processo de sedentarização. Na sua dimensão civilizacional, os rios são um fator determinante do povoamento humano. Primeiro na busca das terras mais férteis. Depois, com o crescimento demográfico, na expansão territorial das comunidades. Ou ainda na escolha da localização mais adequada para desenvolver o comércio que se estabeleu entre locais dispersos, mas que os rios permitiam ligar enquanto veículos primordiais de circulação. Marcam indelevelmente os sistemas construtivos locais tradicionais, quer pelos materiais que são extraídos dos seus leitos e margens, quer pelos materiais que permitiam transportar. Mas estão também presentes na emergência de guerras e de conflitos inerentes à defesa da propriedade e à conquista das melhores localizações estratégicas. Como ainda na evolução técnica e tecnológica. Não é por acaso que muitas das atuais fronteiras são delimitadas por rios. Não é por acaso que a maior parte das capitais nacionais são atravessadas por rios. Como não é por acaso que os rios, hoje como no passado, sempre tenham sido alvo de grandes e experimentais obras de engenharia (pontes, barragens, diques, canais, mudanças artificiais de leito, etc) que traduziram a capacidade de inovação humana. Os rios são documentos que permitem ler a história dos lugares, retratar os episódios marcantes e dar conta das dinâmicas sociais presentes em cada momento da nossa existência.

Os rios correm para outros rios ou correm para mar. Metaforicamente, a humanidade corre, também ela, para o mar. Mas há algo nestas duas 'corridas' que é mais significativo que a coincidência da metáfora. A concentração crescente da população mundial junto aos cursos de água e, sobretudo, na orla costeira do planeta, revela bem a importância civilizacional dos rios. Dos aglomerados populacionais que se estabeleceram com a expansão da agricultura e o crescimento demográfico que ela motivou; passando pelo facto de os rios terem funcionando durante séculos enquanto 'estradas naturais', que fomentaram novas dinâmicas económicas (comerciais e industriais) e, com elas, o crescimento urbano; não esquecendo que os vales cavados pelos rios facilitaram as infraestruturas modernas (do caminho de ferro às autoestradas), mesmo onde o relevo era adverso; e, não menos importante, que os rios estruturaram as hierarquias urbanas, ou pelas riquezas que geraram, ou por terem mudado naturalmente de curso e de, com isso, terem refeito a ordem de importância das cidades; os rios contribuiram significativamente para formatar a civilização em que vivemos.

Vivemos em civilizações urbanas. Mais de metade da população mundial vive em cidades e as grandes metrópoles não param de aumentar em número e em dimensão. A relação entre rios e cidades é uma marca da nossa civilização. A relação entre a cidade e o rio que a atravessa pode ter-se alterado ao longo da história. Mas rios e cidades são indissociáveis. Uma das características mais marcantes da transição de século que vivemos é, sem dúvida, a conversão das paisagens fluviais em paisagens urbanas. 


\section{Rio abaixo, rio acima - narrativas sobre os rios}

Tendo uma inegável relevância civilizacional, não é de estranhar que os rios se tornem objeto de abordagens transversais e que interessem a todas as áreas do conhecimento científico. Da física à música, da engenharia ao light design, da economia à política, da religião a todas as formas de arte e expressões culturais, as narrativas sobre os rios são muitas e diversas.

Desde que a sedentarização se concretizou nas suas margens que os rios geram experiências e sentimentos dissonantes. O mesmo rio que traz a fertilidade e o alimento na sua corrente pode trazer animais que matam, doenças ou águas poluídas. O mesmo rio que corre tranquilo no seu leito extravasa dele com violência numa fúria destruidora. O mesmo rio onde uns se divertem, nadando e passeando, é o mesmo rio onde outros sofrem as agruras do trabalho e por vezes da escravidão. O mesmo rio que é um obstáculo à mobilidade, constituindo-se como fronteira, é via de circulação.

As narrativas sobre os rios estão presentes nos livros sagrados assim como na literatura contemporânea, sendo importantes para darmos conta dos usos sociais e das especificidades dos rios. Mas também para dar conta que muitas das narrativas passadas mantêm uma atualidade impressionante e que várias dessas narrativas, fazendo parte de um passado remoto num contexto, são o presente de muitos outros contextos. A Bíblia, por exemplo, refere-se a todos os rios do Crescente Fértil relevando aquelas que eram as suas principais funções. Se o rio Jordão (numa característica que guardou mesmo nos tempos pósbiblicos) se apresenta como um rio que não é importante pela sua navegabilidade, mas enquanto barreira natural e fronteira política, o Nilo fica conhecido pela violência das suas cheias e pelas pragas que o seu curso fazia chegar. Juntamente com o Tigre e o Eufrates partilha as narrativas da abundância e da fome, mostrando bem a relação dos rios com a economia e os dramas recorrentes da humanidade, assim como a manutenção da importância que os rios já tinham nos tempos biblicos e a relevância dessa narrativa perante a realidade de, ainda hoje, 95\% da população do Egito depender da produtividade de $5 \%$ do solo nacional, precisamente localizado no leito de cheia do rio Nilo (Kelm, 1991). O Tigre e o Eufrates, que aparecem na Bíblia como dois dos quatro rios dos Jardins do Éden, e como braços do rio principal que regava o Éden, passam grande parte da sua história a mudar misteriosamente o seu curso e a formar novos braços, tal como ainda hoje $90 \%$ do seu caudal não chega ao Golfo Pérsico, perdendo-se entre a irrigação e a evaporação. A sua história e a dos dois restantes rios do Éden participa na narrativa dos rios desaparecidos, uma realidade que não é assim tão incomum se considerarmos os rios que, por razões naturais ou artificiais, mudaram de curso ou os rios que se tornaram subterrâneos em virtude dos processos de ocupação do solo ou de acidentes geológicos. Narrativas que tanto nos trazem à memória as cidades e aldeias que desaparecem ou perdem importância quando os rios mudam de curso, quanto aquelas que conhecem igual destino quando as barragens engrossam os caudais.

O vasto campo da cultura, da "Noite estrelada sobre o Rio Ródano" (de Vincent van Gogh) ao "Danúbio Azul" (de Johann Strauss), passando por "Memórias de um turista" (de Stendhal), entre tantos outros, está cheio de exemplos que enfatizam a relação entre os rios e o imaginário social. Nas artes e na vida, o rio faz flutuar as memórias, cria valores partilhados por comunidades diversas e faz emergir 
normas e instituições. O imaginário social que os rios sustentam junto das comunidades que atravessam cria narrativas que definem modos de convivência e de representação da sua vida coletiva. Vários autores registaram afinidades entre os rios e as comunidades com eles relacionadas: o Reno e as suas gentes são românticos; o Tamisa é imperial; o Ródano é selvagem (Mauch e Zeller, 2008). Nessa dimensão simbólica que o imaginário social transporta, os rios fascinam e criam ilusões que podem ter efeitos reais e que podem abrir portas à mudança e à inovação. As narrativas literárias, que retêm muitos dos imaginários sociais relativos aos rios, mostram que o imaginário de "subir o rio" está muito presente no novo mundo, ligado ao facto de os colonos desembarcarem nos portos e transportarem consigo o desejo de aventura e de descoberta, assim como a ansiedade de levar a civilização até às origens mais selvagens. Em contraste, as narrativas do "descer o rio" parecem estar ligadas à aceitação de nos confinarmos ao destino, de aceitar o curso natural das coisas e de caminhar em relação a um fim: o progresso (McMillin, 2011). Acima de tudo, o que a diversidade de narrativas nos mostra é que a relação entre rios e comunidades, entre rios e cidades ou entre rios e civilizações tem de ser sempre contextualizada.

Na relação que os rios mantêm com as cidades, as narrativas que estão na origem de visões partilhadas da realidade e que originam uma espécie de inconsciente coletivo, tornam-se evidentes na forma como os rios contribuem para a formação de um ethos de cidade. Se as cidades são entidades caracterizadas pela diversidade e pela mudança, elas guardam, todavia, um ethos identitário que carrega o peso da sua história e das referências socialmente partilhadas. Se umas se veem e são vistas, sobretudo, como cidades comerciais, industriais, turísticas, entrepostos agroalimentares ou outra coisa qualquer, isso deve-se, com grande frequência, ao modo como os rios criaram referências simbólicas e modos de viver e de representar a vida coletiva dos indivíduos.

\section{Os rios como despojos da civilização}

Quando, em 1850, a Câmara Municipal de Lyon, confrontada com a ausência de uma morgue municipal, decide instalá-la num barco-morgue, na margem direita do Ródano, fê-lo por duas razões essenciais. Por uma questão de centralidade, uma vez que era absolutamente fundamental que a morgue fosse acessível para que os habitantes locais pudessem proceder à identificação dos corpos e para que funcionasse na proximidade dos serviços mortuários. Mas também porque o rio era a melhor via de transporte de cadáveres, sendo, além disso, ele próprio, de acordo com as estatísticas, o maior depósito de cadáveres não identificados (Vettorello e Vignau, s. d.: 124). As razões desta escolha não dizem tudo sobre os rios, mas são reveladoras das funções sociais que eles foram assumindo ao longo da história. Chegados ao século XIX, as funções sociais de centralidade e de transporte são ainda evidentes. Mas é igualmente evidente que os rios se foram convertendo em contentores de detritos orgânicos e inorgânicos de uma civilização crescentemente urbana.

Como referimos, o crescimento da civilização urbana foi ocorrendo, sobretudo, junto aos cursos de água. Esse crescimento caracterizou-se pela emergência de novas cidades e povoados. À entrada 
do século XIX, só Pequim tinha mais de 1 milhão de habitantes, 7 das 10 cidades mais povoadas eram asiáticas e 3 (Londres, Paris e Nápoles) eram europeias. Todas elas ou eram atravessadas por rios ou situavam-se junto ao mar. Um século depois, consumada a Revolução Industrial na Europa, as 10 maiores cidades tinham ultrapassado todas elas a fasquia de 1 milhão de habitantes, sendo Londres a mais povoada, com mais de 6 milhões de pessoas. Mais de metade (6) dessas 10 cidades eram europeias e 4 estavam situadas nos EUA. Num século, a mudança foi radical, quer em termos geográficos, quer em termos demográficos. Só uma coisa se manteve. Todas as 10 maiores cidades do mundo no início do século XX ou eram atravessadas por rios ou se situavam junto ao mar. Chegados ao século XXI, a mudança volta a ser radical, uma vez que há 3 novas cidades sul-americanas entre as 10 mais populosas, uma norte-americana e 6 asiáticas. Destas 10 cidades, onde já não há nenhuma europeia, só Tóquio (que já fazia parte da lista em 1800 e em 1900) e Nova lorque (que em 1900 integrava as 10 mais populosas) se mantêm. Todas as outras são cidades que cresceram no século XX, 3 das quais situadas na Índia. Curiosamente, uma das mais populosas, se não a mais populosa (a cidade do México) não é nem costeira, nem atravessada por um rio, situando-se a mais de 2000 metros de altitude. Mas no seu súbito crescimento, engoliu cerca de 70 rios que a atravessavam e que, entretanto, se tornaram subterrâneos. André Guillerme, ao analisar a história da água na civilização ocidental, sublinha que:

"Textêis, couros, papel e nitratos representam em volume a maior parte dos produtos transformados nas e pelas cidades até ao início do século XVIII. Os seus modos de produção dependem intimamente da humidade e da putrefação, ou sobretudo da quantidade de excrementos produzidos na cidade. A água e o esterco são na economia artesanal riquezas fundamentais que é preciso armazenar e acumular. Neste sentido, os detritos e a água estão para o artesão como o ouro e o dinheiro estão para o Estado no quadro da economia mercantilista." (...) É por isso que desde sempre, as margens dos grandes rios ladeados de grandes florestas foram escolhidas para a construção das grandes cidades (...)" (Guillerme, 1983: 169).

Por estranha e ousada que possa parecer esta explicação de André Guillerme, a verdade é que, chegados ao século XVIII, a civilização urbana, e a sua organização social e económica, vivem profundos problemas de insalubridade. Os rios continuam a ser uma peça-chave do desenvolvimento económico e continuam a estruturar as funções sociais dominantes. Uma das pretensas vantagens do barco-morgue de Lyon era a de conservar os corpos através da sua humidificação, na medida em que permitia uma irrigação contínua dos cadáveres através de um sistema de bombas que traziam a água do rio para cima dos cadáveres de modo a travar a sua putrefação, devolvendo depois a água ao rio. Noutros continentes, da China à América do Sul, onde o desenvolvimento económico e o crescimento demográfico não colocavam uma pressão tão grande sobre as cidades e os rios, a mesma tendência se registava. Era sobretudo uma questão de tempo e de escala. Mas os rios estavam a tornar-se, globalmente, os contentores dos despojos da civilização urbana. No início do século XIX, o caudal do Rio Pelotas - que servia de matadouro para a produção de charque que alimentava os escravos brasileiros, e para escoar os detritos orgânicos das vacas mortas nesse processo - tinha uma inusitada cor vermelha 
e um cheiro não menos estranho. Por tudo isso, André Guillerme sustenta que "A putrefação adere à cidade como a humidade que se cola a este longo período de arrefecimento climático. Uma e outra determinaram a riqueza da cidade; quanto mais uma cidade cheira mal, mais ela é rica. A putrefação é um suporte da urbanização (...)" (Guillerme, 1983: 179).

Confirmando esta ideia que relaciona de forma estreita putrefação e urbanização, durante toda a Idade Média europeia - dada a especificidade das cidades medievais: fechadas sobre si próprias, com ruas estreitas que são uma extensão da casa e das funções domésticas, onde as funções residenciais se misturam ainda com as funções artesanais e produtivas em espaços exíguos -, a água é um elemento presente, circundante e visualizável. ${ }^{2}$ Mas, como bem nota Gabriele Lechner, os rios, nos seus fluxos urbanos, parecem estar irreversivelmente convertidos em coletores de águas usadas e nauseabundas (Lechner, 2006: 7). O espírito das Luzes, no século XVIII, e o movimento higienista, na primeira metade do século XIX, transportam reações filosóficas e práticas a esta situação, até porque a Revolução Industrial e um crescimento demográfico cada vez mais intenso vieram agravar uma situação que se mostrava cada vez mais como insustentável.

Gabriele Lechner (Lechner, 2006) mostra que, em nome da higiene e da salubridade, se assiste progressivamente a um processo de domesticação dos rios e de "desidratação das cidades" e que, no âmbito desse processo, a água vai sendo retirada da vida quotidiana dos cidadãos. A Revolução Industrial, por sua vez, vem consumar a separação entre os rios e as cidades. Mas isso não significa que os rios se tenham libertado das agruras da urbanização e da civilização. Pelo contrário, aos detritos domésticos e artesanais vieram juntar-se os detritos industriais. Nessa medida, a condição de invisibilidade dos rios enfatiza a sua função de reservatório dos despojos da civilização. O lançamento de esgotos domésticos e industriais nos rios das duas maiores cidades europeias da primeira metade do século XVIII (Paris e Londres) originou vários surtos de cólera que mataram milhares de pessoas. Nada de muito diferente do que se passa na Índia dos nossos dias. Por um lado, os rios parecem desaparecer em detrimento dos portos, que passam a concentrar as atividades fluviais mais relevantes. Por outro lado, as fábricas e armazéns tomam conta das margens dos rios, quer porque os rios continuam a ser meios de transporte privilegiados, quer porque os cursos de água são fundamentais para alimentar caldeiras e moinhos, quer ainda porque os rios são a solução mais fácil para fazer desaparecer os despojos industriais. Esta realidade foi sobretudo visível na Inglaterra dos séculos XVIII e XIX, onde muitas cidades conheceram mudanças drásticas e se tornaram irreconhecíveis. A Inglaterra dessa época é vista como um lugar onde os rios são divididos, os canais são repentinamente rasgados e as montanhas minadas. Mas é também um país onde o desenvolvimento das cidades que conheceram um impacto mais forte da Revolução

2 Na obra "Paris au Moyen Âge", Pascal Varejka (Varejka, 1998) dá conta desses usos ancestrais que atravessaram toda a Idade Média, quando afirma que a salubridade das ruas não era a primeira preocupação dos habitantes da cidade, uma vez que atiravam água suja pelas janelas e mesmo os dejetos dos penicos. De modo que, para proteger os transeuntes, foi tornado obrigatório, em 1372, gritar 3 vezes "Cuidado com a água!", antes de atirar água pela janela. Regos de água choca mal cheirosa corriam pelo meio das ruas e quando chovia era praticamente impossível transitar nelas. 
Industrial (Manchester, Sheffield, Nottingham ou Bradford) tinha sido sustentado, durante séculos, no uso dos rios. E foram, precisamente, os rios que permitiram incubar a Revolução Industrial. Aqui, como na Cidade do México, a maior parte desses rios são hoje subterrâneos.

Inclusive nos países que não conheceram a experiência da Revolução Industrial, ou que a viveram mais tarde e de forma mais limitada que a Inglaterra, os rios não escaparam a essa função social de funcionarem como reservatórios dos despojos de uma sociedade cada vez mais concentrada em grandes cidades. O Brasil, a China e a Índia, que são economias emergentes com populações numerosas, são disso um exemplo. A Índia, por exemplo, é conhecida por ter um incomensurável problema de poluição das águas, devido ao lançamento dos esgotos não tratados nos rios. O Ganges, o Yamuna e o Kaveri, que atravessam zonas densamente povoadas, têm elevados níveis de poluição. Em 11 de dezembro de 2011, a revista "The Economist" (The Economist, 2011), num dossier especialmente consagrado à Índia, abordava especificamente essa questão da seguinte forma:

Para saber por que morrem todos os dias, de diarreia, 1000 crianças indianas, faça um pequeno passeio ao longo do Ganges em Varanasi. Quando entra na cidade, o rio sagrado do Hinduísno contém 60000 bactérias de coliformes fecais em cada $100 \mathrm{ml}$ de água, 120 vezes mais do que é considerado seguro para tomar um banho. Quatro milhas mais abaixo, com o insumo de 24 canos de esgoto jorrantes e com 60000 peregrinos a banharam-se no rio, a concentração é 3000 vezes acima do limite de segurança. Em alguns lugares, o Ganges torna-se preto e séptico. Cadáveres, de adultos semicremados ou de bebés cobertos com mortalhas, fluem pelo rio.

\section{Processos fluviais e processos de urbanização}

A urbanização e a industrialização, sobretudo na Europa e na América do Norte, são os dois processos mais marcantes da transformação dos rios, assim como da diversificação dos seus usos sociais (Castonguay e Evenden, 2012). A partir do século XVIII, sobretudo nas áreas urbanas e industriais, as margens dos rios começam a ser regularizadas, potenciando a navegabilidade e o comércio, ao mesmo tempo que se controlavam as cheias. Essas operações, que correspondem a um primeiro momento de intervenção estatal nos rios, caracterizam-se por reduzir as dimensões de sociabilidade da água e dos cursos de água. Gabriele Lechner defende que o Estado, sob o pretexto de estar a controlar as inundações, vai consumar $\mathrm{o}$ isolamento entre as cidades e os rios, ao mesmo tempo que isso the permite mais facilmente cobrar impostos sobre a circulação nos rios (Lechner, 2006). Para a autora, os séculos XIX e XX assistem à realização de projetos fluviais de cada vez maior envergadura, uns ligados à agricultura, outros à indústria e outros ao comércio. Ao mesmo tempo, nas cidades, os portos urbanos perdem relevância ou extinguem-se, "os últimos braços mortos dos rios desaparecem e os pequenos afluentes, inicialmente canalizados, são enterrados." (Lechner, 2006: 8) Os grandes projetos hídricos e hidroelétricos alteram os caudais, mudam os fluxos, as relações da população com os rios, o clima, as paisagens e a identidade local. 
A evolução da ciência moderna e, com ela, a invenção da hidrologia levaram a uma transformação sem precedentes dos rios. A abertura do canal do Midi, em 1681, para ligar o Atlântico ao Mediterrâneo foi apenas o primeiro passo de um processo que a ciência moderna viria ampliar e acelerar. Mauch e Zeller (2008) destacam o facto relevante de este processo de pacificação dos rios ter ocorrido, em muitos casos, debaixo da alçada de empreendimentos militares. Nos EUA, a instituição mais importante de gestão dos rios é ainda um braço militar, nomeadamente a Army Corp of Enginneers (Mauch e Zeller, 2008: 3). Melissa Samet que faz uma análise detalhada de vários grandes projetos de transformação dos rios americanos, conclui ser necessário desenvolver projetos sem a Army Corps (Samet, 2007) e Paul Kibel refere-se a esses projetos como "Cavalos de Tróia" que facilitaram fenómenos devastadores como os do furacão Katrina (Kibel, 2007: 200). Dessa transformação sem precedentes faz parte o boom mundial de construção de barragens, que se iniciou nos anos 1930, por vezes associado a fenómenos de transvase de uns rios para os outros. Mauch e Zeller (2008) dão conta que nos anos 1970 eram lançados, em média, mais de dois concursos públicos diários de construção de barragens e que a World Comission on Dams estima que cerca de 80 milhões de pessoas tenham sido deslocadas em virtude deste processo. Estes autores salientam ainda o facto de, em 2000, a World Comission on Dams ter registado a existência de mais de 45 mil grandes barragens em todo o globo. Relevando que a construção de barragens preenche importantes funções simbólicas, na medida em que glorifica a capacidade das nações, é sinónimo de desenvolvimento e progresso económico. Daí que tenha sido um fenómeno que não se limitou aos países mais desenvolvidos, tendo conhecido também um forte impulso nos países do hemisfério sul que se tinham libertado da colonização, sendo que a maior barragem à face da Terra (Hidroelétrica das Três Gargantas) foi concluída já no século XXI (em 2006, na China). Os rios, hoje como sempre, participam nos processos de construção identitária das nações, preenchendo um uso social de vincado teor político e ideológico. Não é despiciendo notar que os atuais maiores projetos de construção de barragens estejam a ocorrer nas nações emergentes que fazem parte dos BRIC, designadamente a China, a Índia, a Rúsia e o Brasil³.

Com estas mudanças, e sobretudo com a perda de importância do comércio de proximidade para o comércio global, mas também com a emergência, no século XX, de novos meios de transporte, os rios veem abrandar ou enfraquecer muitas das funções económicas que tinham tido no passado. Na segunda metade do século XX, e em alguns países ainda na primeira metade do século, a prioridade passa a ser dada ao transporte rodoviário e ferroviário. Como os vales dos rios, e em concreto as suas margens, se apresentavam como os locais mais adequados para desenvolver essas infraestruturas (até porque, em geral, o relevo era menos acidentado e porque, sendo terrenos públicos, não tinham custos de aquisição ou de expropriação), o que acabou por acontecer foi um agravamento da separação dos rios de todo o seu entorno. Antes consumado pelo desenvolvimento da indústria e das obras de regularização das margens. Depois, mesmo em meio urbano, pela construção de infraestruturas rodoviárias

3 A China tem a maior central hidroelétrica do mundo, sendo que o Brasil tem 3 das 10 maiores e a Rússia tem duas. 
e ferroviárias. Gabriele Lechner sustenta que os rios são relegados para segundo plano, para um lugar visível mas inacessível, e que a ligação entre margens se torna muitas vezes impossível (Lechner, 2006).

À medida que os rios iam perdendo as suas funções económicas tradicionais, depois de terem estado sujeitos às pressões do crescimento demográfico, aos usos que os tornaram lixeiras e canais de esgoto, aos malefícios ambientais da agricultura produtivista e às consequências da Revolução Industrial, uma outra ameaça decorrente do processo de urbanização estava por vir. A segunda metade do século XX e o crescimento urbano das metrópoles, designadamente nas regiões menos desenvolvidas do mundo, estão particularmente marcados por conflitos entre processos fluviais e processos de urbanização. Lucia Costa traduz este conflito na fórmula "cidades invadindo as águas e águas invadindo as cidades." (Costa, 2006: 10)

Se é verdade que durante séculos as cidades se debateram com o problema das cheias, não é menos verdade que o fenómeno inverso, as cidades invadindo os rios de todos os modos, se tornou mais recorrente e mais grave. E não se trata apenas de habitações informais ou irregulares em relação às quais os poderes públicos fecham os olhos. Em muitos casos, alguns deles dramáticos, correspondem a políticas estatais deliberadas. Na China, o desenvolvimento urbano aniquilou, desde os anos 1990, em cada ano, cerca de 1000 rios com bacias hidrográficas superiores a $60 \mathrm{Km}^{2}$. Dos cerca de 50 mil rios com bacias hidrográficas acima dos $62 \mathrm{Km}^{2}$, que existiam na China há 20 anos atrás, 28 mil despareceram. A certeza que os rios, direta ou indiretamente, vão dar ao mar é uma verdade cada vez mais questionável. Progressivamente, sobretudo nas grandes cidades, foi-se tornando cada vez mais difícil para os pequenos rios o atravessamento dos tecidos urbanos. Os conflitos entre os processos fluviais e os processos de urbanização, devido à especulação imobiliária, ao alargamento incessante das malhas urbanas e à permissividade construtiva em cima e na proximidade das linhas de água, tem conduzido a alterações drásticas na estrutura ambiental dos rios (Costa, 2006). Paradoxalmente, se uns rios desaparecem, outros, por via dos processos de sedimentação agravados por processos de construção de edifícios, diques e barragens, veem o seu leito subir de nível a um ritmo sem precedentes.

Por outro lado, atendendo a que os processos de urbanização mais intensos ocorrem atualmente nas zonas menos desenvolvidas do mundo, em muitos casos sob a forma de construção de favelas, e que grande parte da construção de favelas na Ásia está a ocorrer nas margens dos rios, Kate Harriden questiona-se sobre o impactos da "slum urbanisation" nos processos fluviais dos rios tropicais (Harriden, 2012). Na opinião da autora, para se fugir a uma visão demasiado ocidental e maniqueísta, é forçoso reconhecer que a relação entre processso fluviais e processos de urbanização não se fez num dia, nem por todo lado do mesmo modo e que os rios tropicais têm especificidades próprias que caracterizam essa relação.

\section{Esse rio é a minha rua}

Durante muito tempo, as cidades e as pessoas viraram as costas aos rios, limitando-os a usos industriais e comerciais e empobrecendo as funções sociais que eles podiam desempenhar, 
e empobrecendo igualmente as culturas que os rios fizeram emergir através das suas paisagens e dos seus usos sociais (Halgand, 2010). No séculos XIX e XX, as pessoas fugiam das cidades, procurando redutos circundantes na natureza, para poderem praticar lazeres fluviais. São muitas as cidades de hoje que lamentam o facto de estarem de costas voltadas para o rio que as atravessa. A partir da segunda metade do século $X X$, e muito particularmente nas últimas décadas do século, num segundo momento de intervenção estatal, e com as preocupações relativas aos distúrbios ambientais a agravarem-se, assim como a tomada de consciência em relação à finitude dos recursos naturais, sendo a água o mais importante, os rios voltam a entrar nas agendas urbanas promovendo formas de reconciliação com as cidades (Gorski, 2010). Em todo o caso, a ideia que estamos a passar de uma fase de rutura entre rios e cidades para uma fase de reconciliação (idem) ou a ideia que a requalificação das frentes de água e das margens dos rios permite ultrapassar as limitações das fases anteriores da requalificação urbana (Kibel, 2007) são argumentos que nos parecem um pouco forçados. São muitas as ameaças que pairam sobre os rios e, não obstante os bons exemplos, muito está por fazer. Convém lembrar que os autores europeus que escrevem sobre os rios tendem a focar-se mais nos aspetos ambientais e culturais e, ao contrário do que acontece com os autores americanos, menos nas políticas de água. Os europeus tendem igualmente a concentrar-se nas várias funções económicas, sociais e culturais dos rios urbanos (Mauch e Zeller, 2008). Nessa medida, na Europa, tem-se menos uma análise que incida sobre o rio na sua globalidade, pelo que é fundamental que não se tome o todo pela parte que nos está a permitir ver e viver hoje os rios de uma outra forma.

Ainda assim, é inegável que existem agendas internacionais e modelos globalizados de intervenção que estão a trazer os processos fluviais para o centro dos debates sobre as questões urbanas. Ao mesmo tempo que reivindicações relativas à qualidade de vida e à sustentabilidade urbana parecem querer dar ao rios o estatuto de rua que eles já tiveram. Também aqui, convém não esquecer, todavia, como lembra Maria Cecília Gorsky (Gorski, 2010), a "cantilena saudosista e nostálgica" que enfatiza o facto de os rios já terem sido significativos, de trazerem lembranças agradáveis da sua época de balneabilidade, de terem representado uma fonte de rendimento e de riqueza e de terem contribuído para a formação das paisagens. Até porque, a importância que os rios parecem estar a assumir se resume muitas vezes a intervenções simbólicas e localizadas que participam da ideologia da promoção da qualidade de vida. Tanto mais que essas intervenções parecem estar vocacionadas para que os rios preencham a função social de alimentar um mercado urbano de lazeres e a cultura visual do consumo.

Nesta perspetiva, é curial registar que os rios passaram ou estão a passar de uma dimensão funcional a uma dimensão patrimonial. Gabriele Lechner constata que a água, que foi progressivamente banida do meio urbano, está de volta às cidades (Lechner, 2006). Esta inversão de processos, particularmente visível nas áreas de antigos portos e de zonas industriais decadentes, está a fazer emergir projetos de requalificação e de construção de novas centralidades urbanas. Os rios votados ao esquecimento estão hoje a ser inseridos nas estratégias urbanas de desenvolvimento. "Tornar as margens acessíveis", "integrá-las na organização urbana", "virar a cidade para o rio", "colocar o rio no coração da cidade", são hoje fórmulas amplamente divulgadas pelos agentes desses processos que 
catapultam os rios para o seio das estratégias locais de desenvolvimento. Nas grandes e nas pequenas cidades, zonas de lazer e espaços de prática de desportos náuticos multiplicam-se para favorecer o turismo fluvial (Lechner, 2006).

É ainda Gabriele Lechner (2006) que constata o desejo transversal de, numa ótica patrimonial, se promover a integração das paisagens nos projetos de ordenamento urbano. Tanto mais que, atualmente, a água se apresenta globalmente como um bem raro e ameaçado, o que faz com que os rios adquiram essa função social de elemento estrutural da paisagem e do património. O termo paisagem não é apenas um termo incontornável e omnipresente dos projetos de requalificação das frentes de água. É sobretudo um elemento federador que permite dar conta da continuidade dos espaços fluviais, que fazem da cidade parte de um território mais vasto e que permitem tentar encontrar coerências territoriais a uma escala mais ampla (2006, p. 47). É neste contexto que se pode afirmar que os rios, depois de terem passado de paisagens fluviais a paisagens urbanas, estão hoje a passar para uma dimensão patrimonial.

Foz

Os rios são agentes da História (Stroshane, 1998). Os grupos humanos alteraram as características dos rios ao longo do tempo, adaptando-os a diferentes usos económicos e sociais. A revolução industrial e urbana que ocorreu no mundo ocidental foi o fenómeno que mais alterou o modo como as sociedades usam os rios. Com essa revolução, os rios "entraram no processo de urbanização. (...) A urbanização refez os rios, é certo, mas os rios também limitaram as possibilidades, moldando as formas e as funções urbanas, e com uma previsível imprevisibilidade desafiaram as fundações da vida urbana com riscos de vários tipos." (Castonguay e Evenden, 2012: 238) Nessa medida, "as necessidades sociais e económicas, os valores ecológicos, as preferências estéticas e as identidades nacionais moldaram as perceções e o design dos rios em diferentes regiões e países (Mauch e Zeller, 2008: 7). Por isso, é forçoso reconhecer que, além das tendências comuns, cada rio tem as suas especificidades e que os rios e os desafios que se lhes apresentam estão hoje longe de constituir uma realidade única com soluções modelares. Na dimensão patrimonial que hoje assumem através do conceito de 'paisagem fluvial' e das operações de requalificação em curso, os rios transportam um desafio maior. O de promover a apreensão global do território que eles atravessam, fomentando intervenções integradas de ordenamento e de animação ao longo do seu curso.

\section{Bibliografia}

Castonguay, Stéphane e Matthew, Dominic (Orgs.) (2012), Evenden. Urban Rivers: Remaking Rivers, Cities, and Space in Europe and North America. Pittsburgh: University of Pittsburgh Press.

Costa, lucia Maria Sá Antunes (2006), "Rios urbanos e o desenho da paisagem." Rios e palsagens urbanas em cidades brasileiras, lucia Maria Sá Antunes Costa (Org.). Rio de Janeiro: PROURB-FAu-UfrJ, 9-15. 
Gorski, Maria Cecílla Barbieri (2010), Rios e cidades: ruptura e reconcillação. Rio de Janeiro: SenaC. Guillerme, André (1983), Les temps de l'eau - La Cité, l'Eau et les techniques. Seyssel: Editions Champ Vallon. Halgand, Nathalie (2010), Le paysage fluvial urbain. Paris: Centre de ressources documentaires de L'Inp. Harriden, Kate (2012), Potential impacts of slum urbanisation on channel bank storage in the Bang Pakong River, Thailand. Water Practice \& TeChnology 7(4), 1-7.

Kelm, George L. (1991), "Rivers and Waterways in the Bible". Holman Bible Dictionary. Trent C. Butler (Org.). NASHVILLE: BRoAdMAN \& Holman.

Kibel, Paul Stanton (2007), Rivertown: Rethinking Urban Rivers. Cambridge, MA: Mit Press.

Lechner, Gabriele (2006), Le fleuve dans la Ville - la valorisation des berges en milieu urbain. Paris: Directio Générale de L'URBanisme de L'Habitat et da la CONSTRUCtion.

Mauch, Christof e Thomas Zeller (2008), Rivers in history: perspectives on waterways in Europe and North America. Pittsburgh: University of Pittsburgh Press.

McMillin, Tracy S. (2011), The Meaning of Rivers: Flow and Reflection in American Literature. Ames: University of IOWA PRESS.

Samet, Melissa (2007), "Bankside Federal." Rivertown - Rethinking Urban Rivers. Paul Stanton Kibel. Cambridge - MA: MIT PRESS, 143-177.

Schneider, Wolf (s. D.) De Babilônia a Brasilla: a cidade como destino do homem, de UR a Utopia. São Paulo: Boa Leitura. Stroshane, Tim (1998), The social lives of rivers. Capitalism, Nature, Socialism 9(3), 147-150.

The Economist (2013), "Creaking, groaning I The Economist." The Economist. 11 de dezembro de 2011. Consultado EM HTTP://WWW.ECONOMIST.COM/NODE/12749787, EM 9 DE MAIO DE 2013.

Varejka, Pascal (1998), Paris au Moyen âge: oyez, oyez, braves gens, la véridique histoire de la grande Cité au temps des cheValiers et des ménestrels. Paris: Parigramme.

Vettorello, Cécile e Marie Vignau (s. d.), L'eau et la santé à lyon - La formation d'une cité. Lyon: Agence d'Urbanisme DE LYON. 
ATLAS 


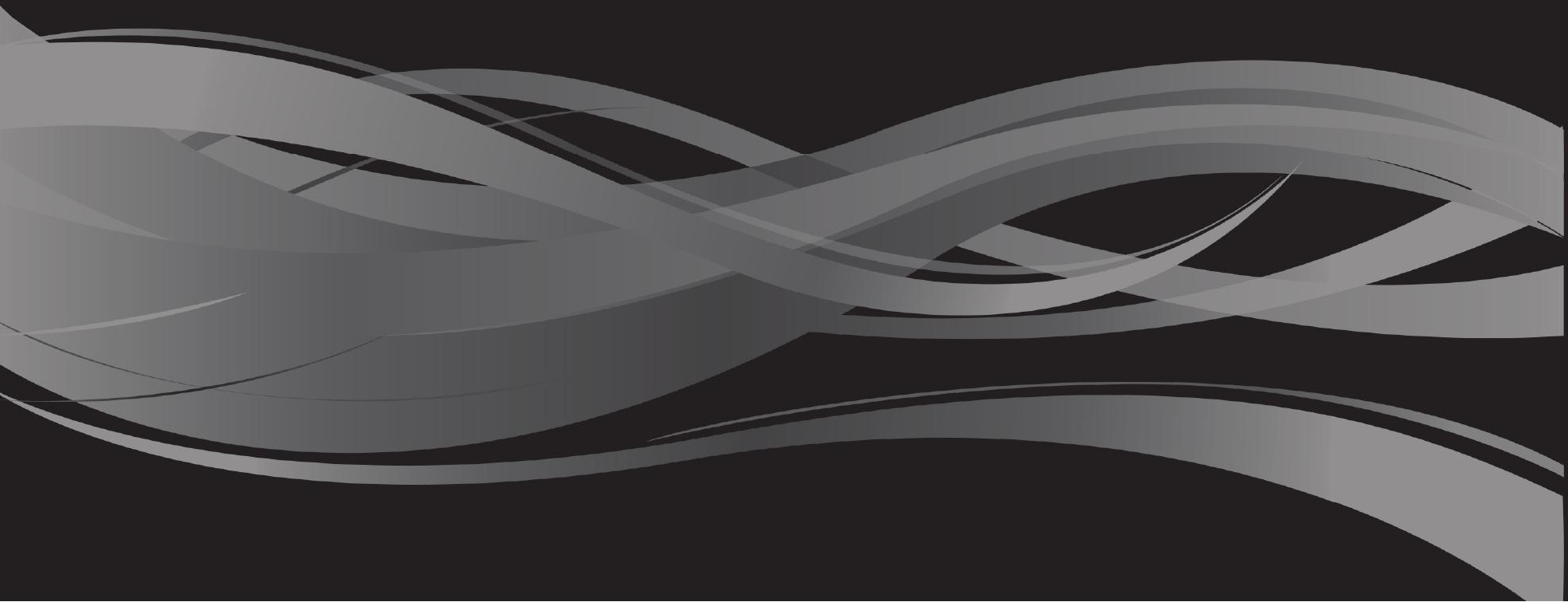




\section{INTRODUÇÃO}

PIERRE PEYRET 


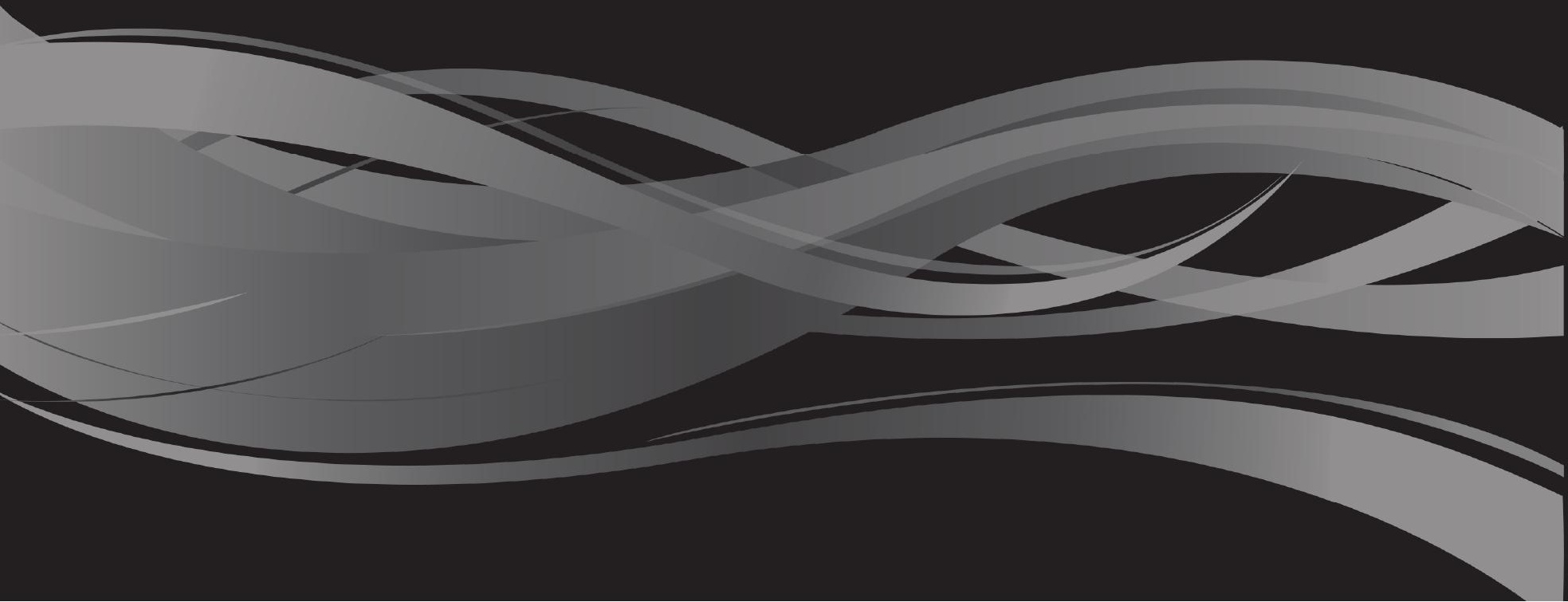


O projeto tem como pressuposto fundador "Água como Património: Experiências e saber fazer na requalificação das cidades e das paisagens fluviais."

A temática é importante mas é particularmente importante a problemática e o método. Participam no projeto as cidades de Comacchio, Lille, Braila e Coimbra. Embora muito diferentes no que toca às suas morfologias, as relações históricas que mantêm com a via de água e a sua evolução ao longo dos tempos tornam pertinente o seu contributo para a riqueza do projeto. O desafio da investigação comum posto em marcha por este projeto tem por finalidade alcançar, no final da reflexão partilhada, contributos operativos concretos através de projetos de requalificação e de reabilitação urbanas que tenham em conta as problemáticas urbanas específicas de cada um destes lugares e das suas vias de água, bem como fazer coincidir as exigências das coletividades territoriais, das escolas de arquitetura, entidades cooperantes do projeto, com o interesse dos cidadãos. Pretende-se que a investigação seja concreta e operativa mas que vá para além do quadro vocacional das escolas de arquitetura. Esta é a base do projeto.

Nesta ótica, a problemática não pode ser um pretexto aferente apenas à requalificação. Estando esta ligada à via de água, é determinada por um elemento imperativo, natural e morfológico caracterizador das cidades que fazem parte deste projeto. A problemática é estratégica.

Através desta problemática e para além dos aspetos específicos, esta investigação coletiva permite trabalhar sobre os diversos aspetos que dizem respeito à requalificação num quadro que convoca, frequentemente, a integralidade da cidade para essa mesma requalificação. Nesta conjetura, reconhece-se a própria essência da cidade num confronto dialético entre crónica e história, geografia física, natureza, hidrologia, sociologia, arquitetura, urbanidade... .

Abrir perspetivas sobre a reabilitação das cidades de água e das paisagens fluviais, é também, antes de mais, encarar o rio como um signo urbano que, com frequência, contribuiu de modo preferencial para a caracterização da morfologia das cidades ao longo dos séculos, determinando a estratificação urbana, os espaços naturais e artificiais.

Trata-se de, como aconteceu frequentemente, tomar em linha de conta a via de água como referência, como estrada principal, como eixo ou raio da estrutura urbana atravessando tecidos urbanos, por vezes diversos, de periferia para periferia, e, por vezes também como centro da cidade antiga, marcando os mais importantes momentos da história urbana. A existência de uma via de água faz dialogar importantes polaridades urbanas. Desde o aparecimento das primeiras instalações humanas, bairros inteiros se articulam ao longo dos tempos, nos momentos históricos mais importantes, uma relação que tem a água como protagonista.

O rio é um signo urbano pleno de sentidos, não apenas morfológico, contribuindo para o desenho da cidade, mas também para a sua estratificação durante séculos, participando na confrontação dos seus espaços vitais naturais e artificiais mesmo se em muitos sítios o curso das evoluções levou à perda dessa relação. Perda sujeita a intensidades flutuantes ou mais ou menos marcadas, de modo mais significativo nos centros das cidades, na cidade histórica onde a vida estava estreitamente ligada ao rio e onde depois foram geralmente construídas fortificações, barreiras físicas, psicológicas, funcionais, percetivas. 
A finalidade deste projeto é pensar, graças às experiências e saberes fazer de cada um, uma recuperação inovadora com os elementos da cultura contemporânea, com as exigências da sociedade, respeitadora de todos os aspetos ambientais, arquitetónicos e naturais e também de modo a tornar a via de água protagonista.

Não é um quadro nostálgico, uma operação de conservação das áreas urbanas atravessadas pelo rio e não se trata também de finalizar um impossível regresso às imagens de uma cidade desaparecida mas antes de imaginar uma reabilitação que, para além da tutela e da salvaguarda dos aspetos ambientais, possa permitir aos cidadãos recuperar esses espaços integrando-os no contexto de hoje e de amanhã.

Entre os espaços mais frequentemente relacionados com a via de água, e frequentemente os mais importantes, encontram-se os espaços que perderam uma função precisa e se encontram em estado de abandono, de baldio. São áreas estratégicas cuja recuperação é fundamental para a valorização urbana.

Os usos citadinos determinam-se pelas práticas e as cidades fluviais por uma abordagem geográfica a uma dada escala.

A via de água encontra a cidade. Esses lugares de encontro representam a interface de dois sistemas, caracterizados pela orla. Como qualquer orla, é uma zona de aparente conflito mas que pode e deve ser também um lugar de trocas, de misturas, de variedade, de polivalência, de mobilidade. Um meio evolutivo e dinâmico.

Como se vive esse contacto?

Frequentemente vive-se como fratura, fronteira, recusa da realidade física, do valor simbólico da via de água, recusa da realidade humana que ela coteja. Ciclo de maturidade, de obsolescência, redescoberta! Para Ihe apreender a dinâmica é necessário lançar um olhar atento para além de qualquer abordagem preconcebida, preestabelecida, para fazer sobressair a personalidade e o diálogo que a via de água poderia estabelecer com a trama dos bairros que atravessa.

Alargar o ângulo de visão e de perceção sobre o seu traçado na cidade, a recetividade à capacidade de discernir os espaços ignorados que oferece e que temos muitas vezes que imaginar. Importa questionar esses espaços esvaziados de sentido, esses lugares por vezes negados, abandonados, enjeitados, congelados, em espera. Tentar captar a energia própria de cada um desses lugares não apenas para tentar dar uma leitura da sua realidade sensível, transgredindo os simples referentes teóricos e culturais para estabelecer uma conivência com as populações ribeirinhas, com os utentes, no campo polissémico dessas polivalências, considerando que o "rio" é um espaço em si mesmo, um espaço vivo e uma parte integrante da paisagem urbana.

É encarar o "rio" como verdadeira estrutura orgânica urbana.

A formulação de soluções de ordenamento assim entendida contribuirá para a construção de uma identidade local distintiva e coerente e para reforçar o sentimento de pertença de todos os cidadãos a esse território particular, frágil, sensível... .

Este projeto de investigação inscreve-se nesta dimensão, tendo em atenção as múltiplas reflexões já empreendidas desde há vários anos sobre a tomada em consideração do valor patrimonial das vias de água, do contexto particular da relação entre as vias de água e a cidade, das realizações já 
empreendidas em numerosas cidades. Mas uma das suas particularidades é a vontade de confrontar as diferentes abordagens culturais, os sítios que diferem pela sua morfologia, pela sua história, pela natureza das vias de água com que cotejam, pelos usos específicos de que foram respetivamente a sede. Pôr em comum essas experiências com vista a desembocar numa abordagem colaborativa, em que cada um contribuirá com a sua pedra para a edificação de um procedimento comum que se inscreva no quadro de uma tomada em consideração da paisagem fluvial como valor fundamental nas estratégias de reabilitação das cidades, e tudo isso no âmbito de um desenvolvimento sustentável.

A articulação do projeto fez-se em torno de três aspetos:

- O primeiro diz respeito à descoberta da importância dos rios e dos ribeiros nas cidades e, por consequência, dos lugares históricos (portos, ribas, baldios, estaleiros, espaços naturais, etc.) como elementos de interesse patrimonial;

- O segundo aspeto determinante está relacionado com a importância dos rios e ribeiras enquanto corredores ecológicos e "estruturas verdes" no interior das cidades e das áreas metropolitanas;

- O último aspeto refere-se às políticas culturais que várias cidades implementaram para aproximar os cidadãos dos seus cursos de água, com vista a contribuir para a redescoberta da importância dos rios europeus e das paisagens de água nas estratégias de relançamento e de reabilitação urbana e paisagística das cidades europeias, bem como na conceção e desenvolvimento dos projetos urbanos em causa.

O resultado final é concretizado com uma exposição e com este livro, lugar de suporte das reflexões sobre os temas estudados durante o projeto e guia das boas práticas, tendo como finalidade ser utilizado simultaneamente nas práticas de governação mas também no debate cultural em torno das paisagens fluviais na Europa. 


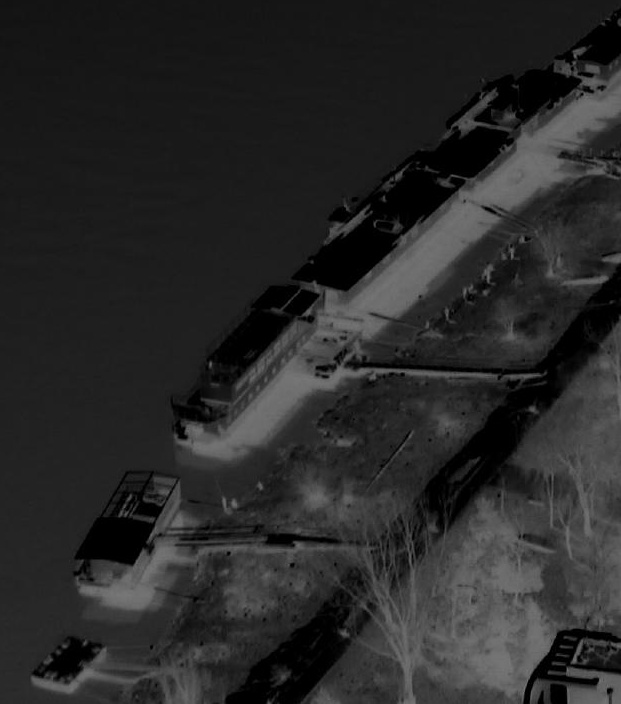




\section{BRAILA \\ CIDADE NO DANÚBIO}

NICOLAE LASCU (Coordenador)

ANDREEA MIRELA CHINA 


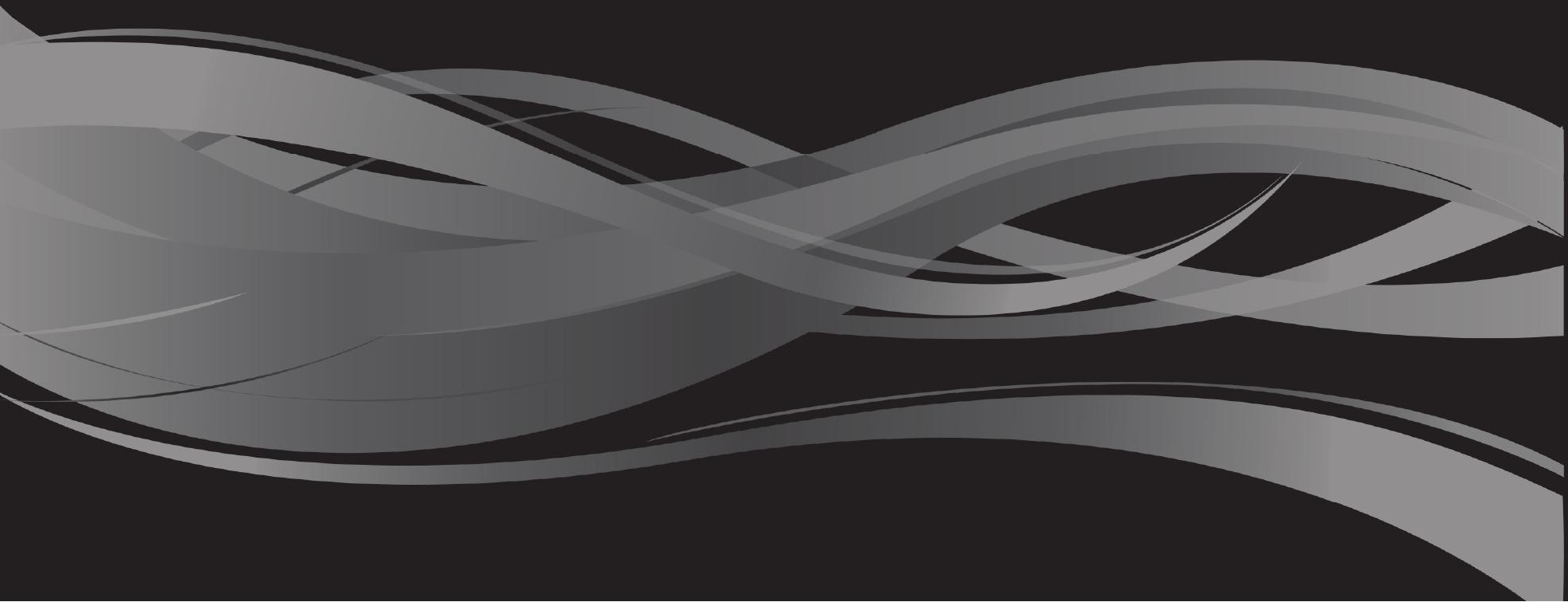


Braila, capital do distrito do mesmo nome, é hoje uma cidade com cerca de 240.000 habitantes. Importante cidade portuária do Danúbio situada no trecho final do rio antes de desaguar no Mar Negro, é também o último porto fluvial até onde as embarcações marítimas de médio calado conseguem subir. Como todas as grandes cidades portuárias, Braila já foi uma cidade multicultural. Nela viveram importantes comunidades gregas e judaicas, bem como de lipovanos e outros povos estrangeiros, conheceu uma vida cultural intensa, e deu ao país prestigiados representantes em domínios que vão das ciências naturais às artes.

Sobre a relação especial de Braila com o rio Danúbio podemos considerar, do ponto de vista do presente projeto, três níveis distintos de complexidade: o problema mais amplo que é o da unidade de paisagem, relativo ao vasto território do Danúbio na Roménia; a questão do sistema urbano Braila-Galati, territorialmente mais circunscrito; e a cidade propriamente dita. Considerada deste prisma, a reabilitação do centro histórico e da frente ribeirinha de Braila não pode ser vista separadamente do desenvolvimento potencial do território do Danúbio no seu conjunto, pois as respetivas histórias estão fortemente interligadas. A água e toda a paisagem fluvial - que há que considerar património, intimamente associado ao próprio património urbano de Braila - articulam-se com a parte mais valiosa da estrutura urbana através da frente ribeirinha, que aqui assume por inteiro o caráter de espaço público.

O Danúbio, segundo maior rio da Europa, com uma bacia de drenagem com mais de 800.000 $\mathrm{km}^{2}$, atravessa nove países e quatro capitais. O canal formado pelo Reno, Main e Danúbio liga o Mar do Norte ao Mar Negro. Isto faz do Danúbio um rio intrinsecamente europeu, conclusão que é reforçada pelas grandes orientações definidas em 2010 pela Comissão Europeia na sua Estratégia da União Europeia para o Rio Danúbio.

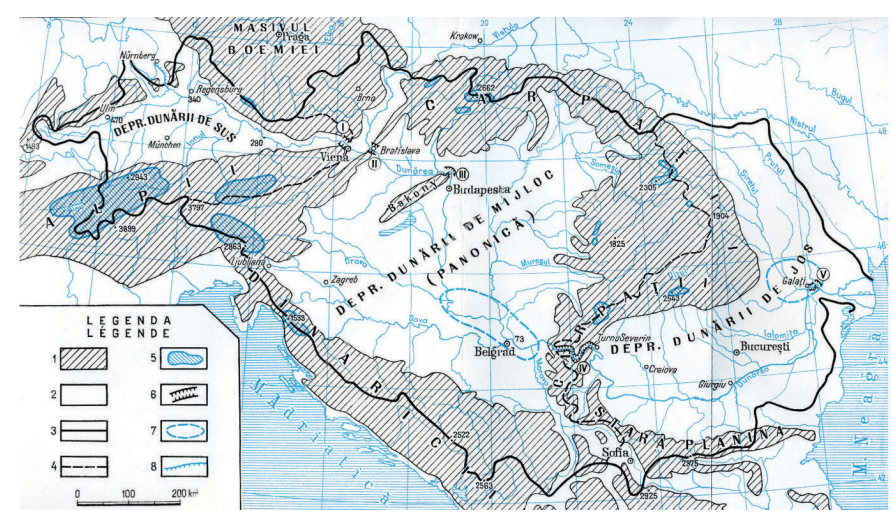

O Danúbio na Europa

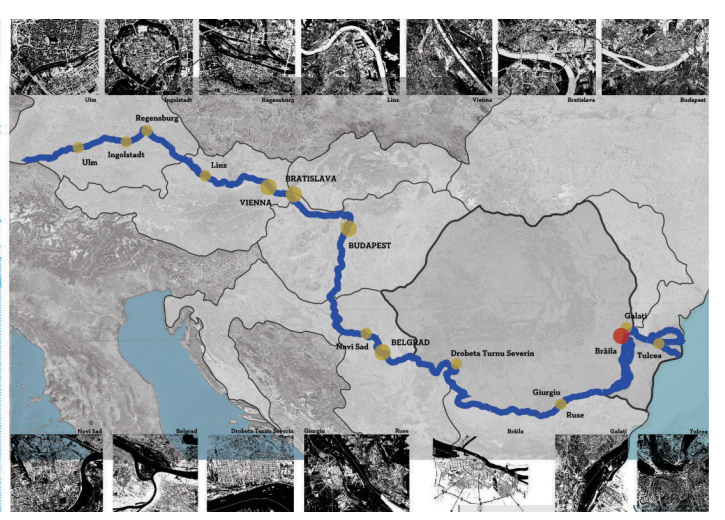

Bacia de drenagem do Danúbio

\section{A unidade de paisagem do território}

Um terço do rio corre em território romeno. Este trecho, chamado Baixo Danúbio, constitui, segundo a Convenção Europeia da Paisagem, uma unidade de paisagem. A unidade de paisagem 
define-se como sendo uma porção de território com caraterísticas comuns: tem de apresentar uma certa coerência, aquirida ao longo da sua evolução histórica, e tem também de ostentar a influência de fatores humanos, nomedamente por parte das comunidades que ali vivam. Por um lado, as unidades de paisagem são, em parte, moldadas pela geografia - no caso do Baixo Danúbio, pelas condições topográficas que influenciam a distribuição das áreas húmidas que ladeiam o rio.

Por outro lado, as unidades de paisagem são moldadas pelas importantes funções simultânea ou sequencialmente desempenhadas pelo espaço geográfico (no caso vertente, o Danúbio). De entre estas destacou-se o comércio, principal catalisador do rápido desenvolvimento, em meados do século XIX, de uma rede de cidades portuárias ligadas entre si. Mais tarde, estas tornaram-se nódulos que iriam viabilizar a articulação de complexas relações regionais, com um papel especialmente importante no desenvolvimento de toda uma rede de povoações e do sistema de transportes (quer dizer, das redes viária e ferroviária). O rio pode, assim, ser considerado um sistema natural complexo, em que as componentes natural e cultural funcionam de maneira concertada.

Depois de atravessar os Cárpatos a caminho do Mar Negro, o Danúbio dá origem a uma configuração muito própria. Ao longo do seu curso, antes de atingir o delta, a margem direita (do lado búlgaro) é mais elevada, sendo a esquerda constituída principalmente pela Planície Romena, terreno plano e de baixa altitude. A complexa configuração geomorfológica do território atravessado pelo Danúbio dá azo à existência de vastas áreas húmidas, que dependem do rio e são por este criadas. O rio e as áreas húmidas criam um todo orgânico, uma paisagem contínua mas diversificada e de largura variável.

O leito principal recebe inúmeros tipos de afluentes, canais, ribeiros, lagos, lagoas, pântanos, leitos de cheia, etc. Estas áreas aquáticas, invariavelmente resultantes da corrente, criam um todo orgânico, uma paisagem que é contínua e diversa, com uma largura que vai até aos $60 \mathrm{~km}$. Por fim, o trecho final do rio, navegável por navios de mar e situado principalmente na região do chamado Delta do Danúbio, é, verdadeiramente, o reino das águas.

A dinâmica das intervenções a que o território do Danúbio foi sujeito teve grande importância após a Segunda Guerra Mundial, altura em que, através de diversas obras hidráulicas, algumas áreas consideráveis - incluindo o Grande Paúl de Braila (por isso mesmo designado Ilha Grande de Braila) - foram reconvertidas para fins agrícolas. Este facto veio alterar especialmente o equilíbrio hidrológico e, de um modo mais geral, o equilíbrio ecológico, numa grande parte do percurso.

Ao longo dos tempos o Danúbio desempenhou diversas funções de vulto, que foram impondo condicionalismos não só às redes de comunicação de terra mas também à estrutura urbana das localidades: funções como a de fronteira natural entre Estados, de facilitador do comércio, e ainda - dadas as possibilidades de transporte fluvial - de gerador de infraestruturas industriais na proximidade das cidades já existentes. 


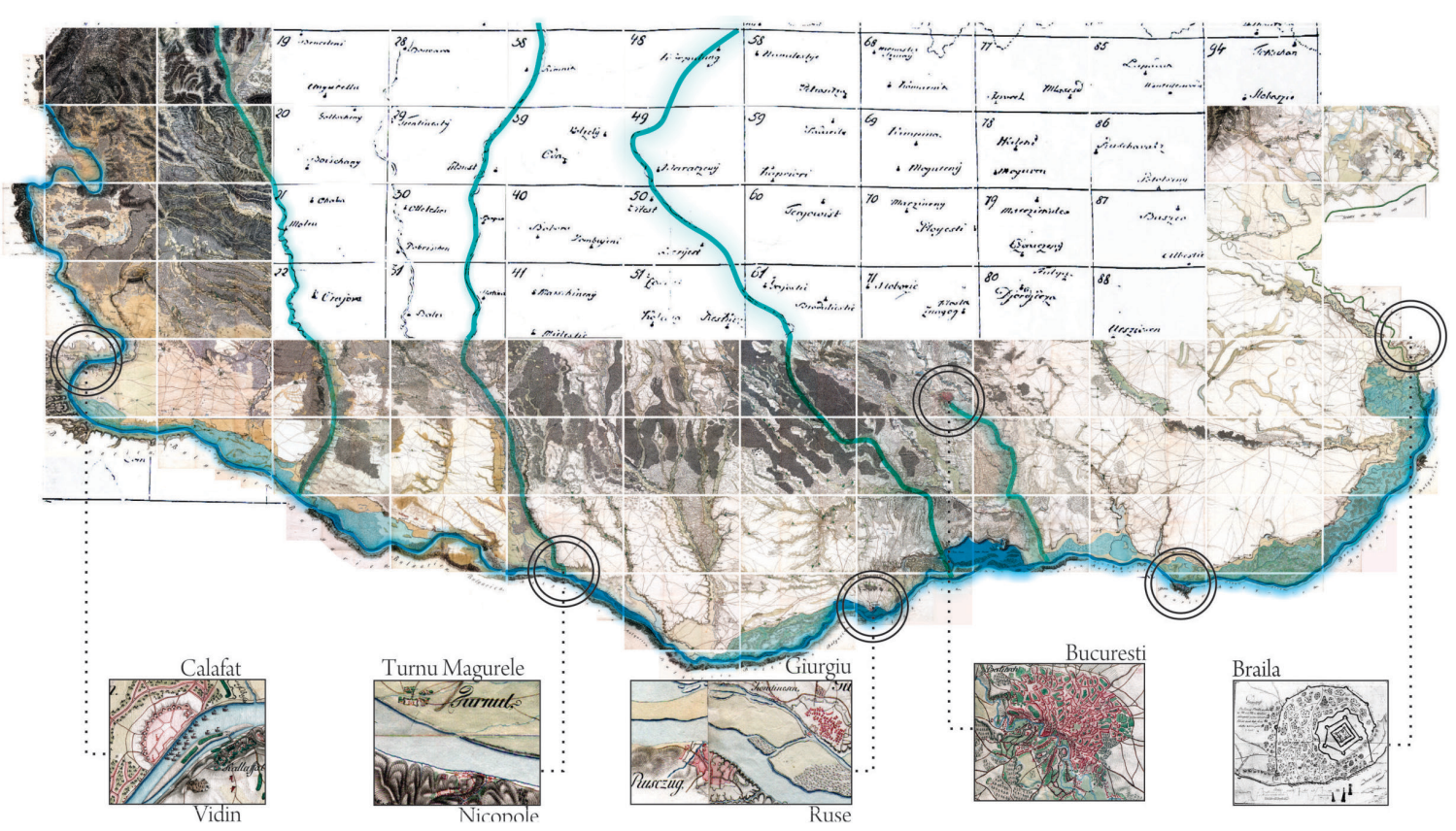

Mapa Militar da Valáquia, de Specht - 1789

A função mais antiga, e que ainda hoje perdura, é a de fronteira natural. Antes de tudo, o Danúbio foi um limes romano. A época romana e, a seguir, a bizantina (entre o século I A.C. e o século VI D.C.) fixaram as fronteiras dos impérios situados junto ao Danúbio, que assim passou a fazer parte dos respetivos sistemas defensivos.

Devido à sua extensão, o limes romano do Danúbio foi a mais importante fronteira fluvial criada pelos Romanos. Durante a época bizantina, do século VII ao século XIII, o rio desempenhou um papel menos importante tanto do ponto de vista militar como do ponto de vista económico, nomeadamente se comparado com a relevância económica e comercial então assumida pelo Mar Negro. Desse modo, nesse período de acentuada instabilidade política o limes romano deixou de existir em toda esta região. Só em meados do século XIV, com a formação dos Estados romenos (Tara Romaneasca e Moldávia), se regressou a um clima político de maior estabilidade, com o decorrente aumento da segurança para o comércio feito ao longo da região situada entre as montanhas e o Danúbio.

Na sua expansão, o Império Otomano alcançou o Danúbio por volta dos finais do século XIV, o que levou a que então o rio se tornasse, a norte, uma fronteira estável para o poderoso império em ascensão. Com a tomada dos fortes de Giurgiu e Turnu entre os anos de 1417 e 1420, e também de Braila na primeira metade do século seguinte (1541) - tudo cidades portuárias da margem esquerda -, os Otomanos asseguraram o controlo sobre o Baixo e o Médio Danúbio. Ao longo do século XVI a função militar do rio foi, aos poucos, sendo complementada pela função comercial, que viria a crescer exponencialmente durante os séculos seguintes. Esta nova função levou ao reforço dos laços entre as duas margens e à criação de cidades gémeas situadas frente a frente numa e noutra margem, com 
o rio a servir de via de passagem (casos de Turnu Severin - Kladovo, Calafat - Vidin, Turnu Magurele - Nicopole, Zimnicea - Svishtov, Giurgiu - Ruse, Oltenita - Turtucaia). As vias de comércio terrestres conduziam aos pontos de atravessamento do Danúbio e às cidades portuárias aí localizadas: as rotas comerciais iam desde Braila e Chilia até Targoviste, e a partir de Oltenia, Giurgiu, Zimnicea, Turnu, Calafat e Turnu Severin chegava-se até Brasov através da passagem de Rucar-Bran. Bucareste, a capital, juntamente com a cidade de Craiova, eram importantes encruzilhadas nestas rotas de comércio.

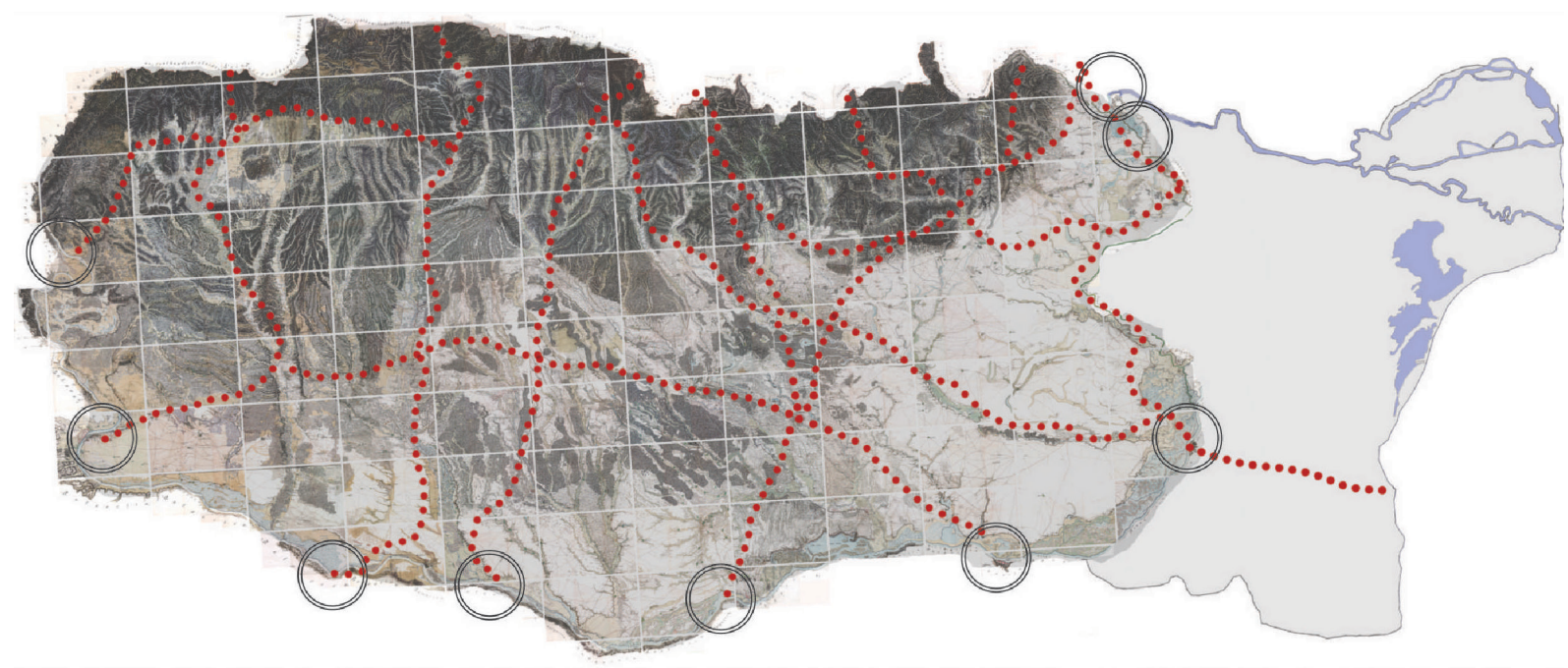

1800 - Rede de estradas e localidades da Valáquia

Para o segmento valáquio do Danúbio a era moderna tem início em 1829 com o Tratado de Paz de Adrianópolis. Este assinalou o fim do monopólio otomano, inclusivamente no respeitante ao rio, garantindo a liberdade de comércio e a reintegração, na Valáquia, dos portos de Turnu, Giurgiu e Braila, situadas na margem esquerda. A partir do momento em que as condições de comércio se alteraram, deixando este de estar voltado em exclusivo para o Império Otomano, o transporte no Danúbio tornou-se um factor económico de importância primordial. Deu-se, assim, uma reorientação não apenas no que se refere à travessia entre as duas margens - que sem dúvida esteve na origem das localidades "geminadas" -, mas também no que diz respeito ao transporte ao longo do rio. Na margem pertencente aos Principados Romenos iniciaram-se em 1832 iniciativas de desenvolvimento urbano com uma dimensão inaudita nestas paragens.

Data de então o desenvolvimento urbano devidamente planeado de 10 cidades portuárias: Braila, Giurgiu, Turnu Severin, Turnu Magurele, Zimnicea, Galati, Oltenita, Corabia, Calafat e Bechet. Alguns destes empreendimentos corresponderam a uma reestruturação significativa de localidades já existentes, enquanto noutros casos se tratou de projetos de desenvolvimento citadino inteiramente novos. No seu conjunto, estes portos de variável importância económica e administrativa vieram renovar por completo o sistema urbano da região danubiana, dando origem a uma nova estrutura territorial no sul do país. 


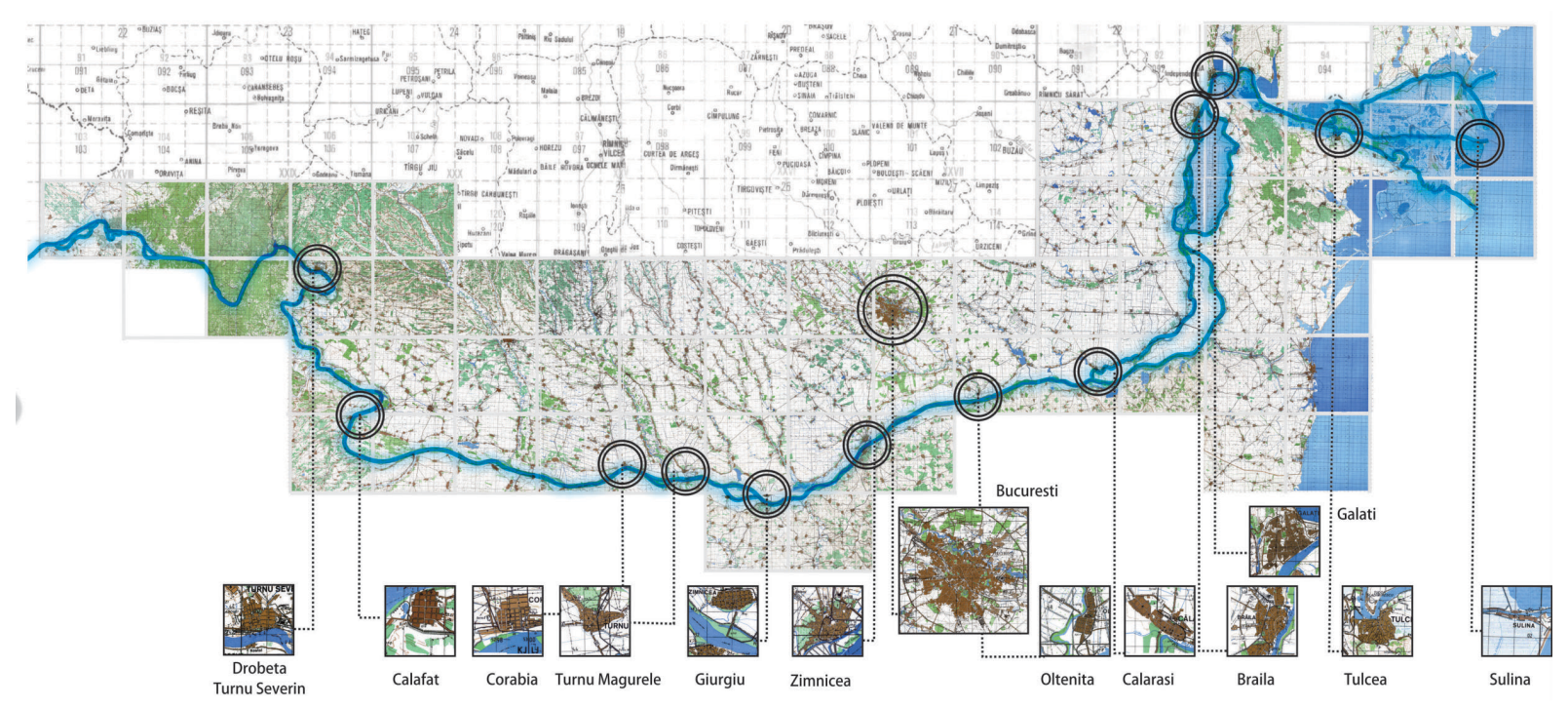

1975 - Mapa militar. O Rio Danúbio na Roménia, com as suas cidades portuárias

A partir de meados do século XIX as intervenções relativas às atividades portuárias foram acompanhadas, em alguns casos, de complexos industriais - estaleiros, mas também fábricas cuja atividade principal era a transformação dos diferentes tipos de mercadorias que para ali eram transportados, quer por via marítima, quer por via terrestre. Após a Segunda Guerra Mundial teve início um gigantesco projeto traduzido na construção, ao longo do rio, de diversas infraestruturas industriais, desde a metalomecânica (Galati, Calarai, Turnu Severin) ao setor químico (Turnu Magurele), passando pela produção de papel (Braila), etc. Outros grandes projetos que vieram mudar a paisagem do Danúbio foram o complexo hidroelétrico das Portas de Ferro, na fronteira com a Jugoslávia, e o canal do Danúbio-Mar Negro, em Dobrogea.

\section{Parte integrante do sistema urbano Braila-Galati}

Uma parte considerável da estrutura das paisagens terrestre e aquática do Danúbio é constituída pelos importantes portos de Braila e Galati, duas cidades da margem esquerda separadas por uma distância de 20 km. Em Dobrogea, próximo de Braila, num antigo canal do Danúbio, fica, na margem direita, um terceiro porto, o de Macin, de importância bem menor. Os três portos têm como traço comum o situarem-se no extremo do trecho navegável por embarcações marítimas, o que quer dizer que a função que lhes é comum advém da sua ligação ao mar. Acresce que a sua relação com a água que os envolve se carateriza por uma grande espetacularidade: a chegada dos rios Siret e Prut ao Danúbio - o primeiro entre Braila e Galati, o segundo a jusante desta última cidade -, a presença do lago Brates e do Paúl de Braila, e ainda a inflexão do curso do Danúbio e a proximidade do delta, tornam a zona uma das paisagens aquáticas mais ricas de todo o rio Danúbio. 
O desenvolvimento económico e urbano que foi ocorrendo paralela e simultaneamente - e que se encontra patente não só no casco medieval mas também, sucessivamente, na moderna infraestrutura portuária e no surgimento e reforço de instalações industriais a seguir à Segunda Guerra Mundial conduziu a uma colaboração estreita entre as cidades mas também a uma certa competição. A investigação hoje em curso visa determinar a viabilidade de um importante macrossistema urbano Braila-Galati dotado de alcance nacional (e que incorpore as cidades portuárias de Macin e Isaccea e eventualmente também, por arrastamento, Tulcea). O estudo prevê que a zona venha a ser um nódulo de comunicações para toda a Região de Desenvolvimento do Sudeste da Roménia.
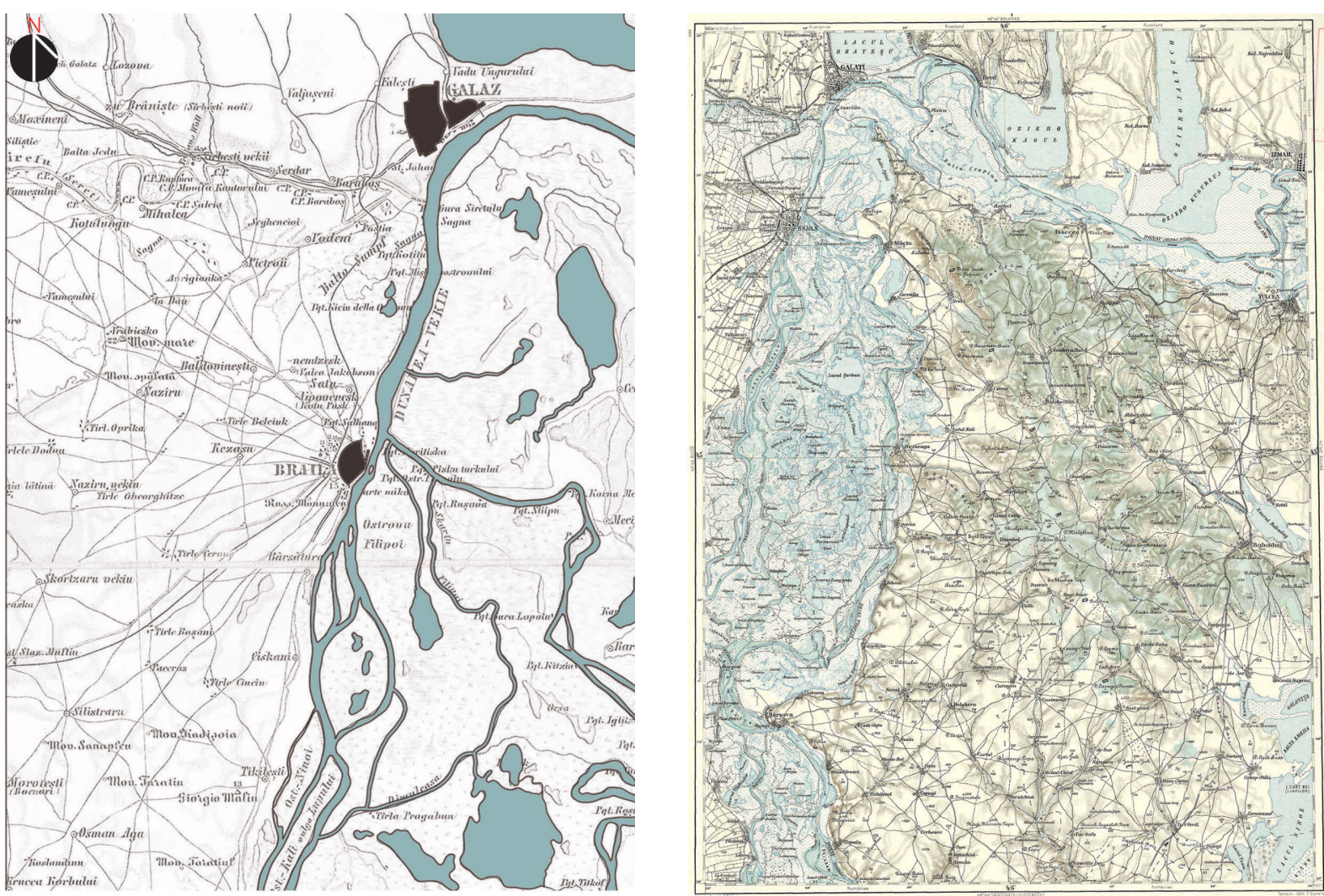

Evolução da paisagem fluvial relativa a Braila e Galati, 1867-1901

O projeto em causa propõe uma relação de maior complementaridade entre as duas grandes cidades, Braila e Galati, a partilha de infraestruturas (como sejam um aeroporto comum ou um nó intermodal localizado em Vladeni) e ligações mais rápidas com Dobrogea (nomeadamente através da construção de uma ponte sobre o Danúbio). Segundo o projeto, o valor excecional da paisagem natural, especialmente no que toca à relação complexa e multifacetada com a água e as áreas húmidas atrás referidas, poderá conduzir ao futuro desenvolvimento de um sistema urbano Braila-Galati que tenha na proteção das paisagens terrestre e fluvial um dos seus pilares fundamentais. 

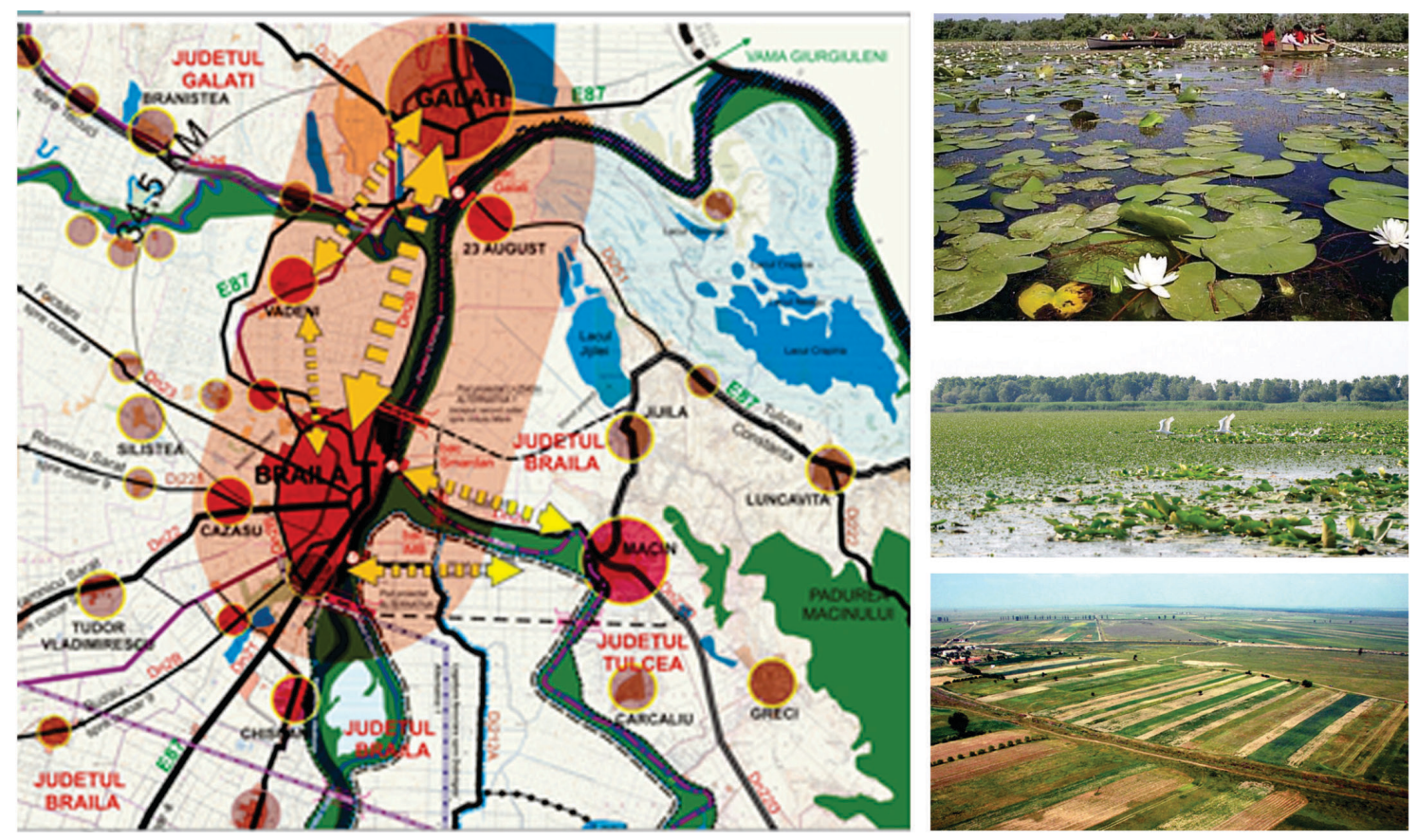

O sistema urbano Braila-Galati e o respetivo ecossistema

\section{Braila - cidade portuária}

Edificada em dois socalcos contíguos, Braila apresenta, de facto, um desnível. As zonas inferiores situam-se cerca de 3 a 4 metros acima do Danúbio, sendo aí que se localiza o porto e as infraestruturas com ele relacionadas. O socalco superior, sobre o qual a maior parte da cidade está construída, eleva-se entre 12 a 25 metros acima do rio, devido a uma vertente íngreme que, em parte, funciona como área de passeio na direção do Paúl de Braila.

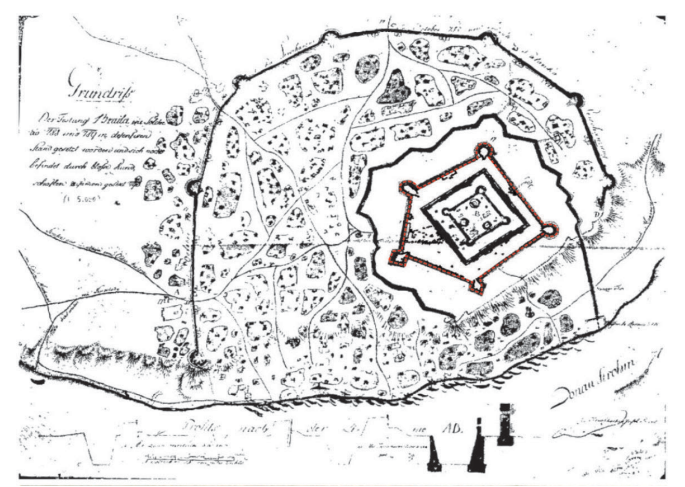

O primeiro mapa de Braila - fortaleza turca, 1789

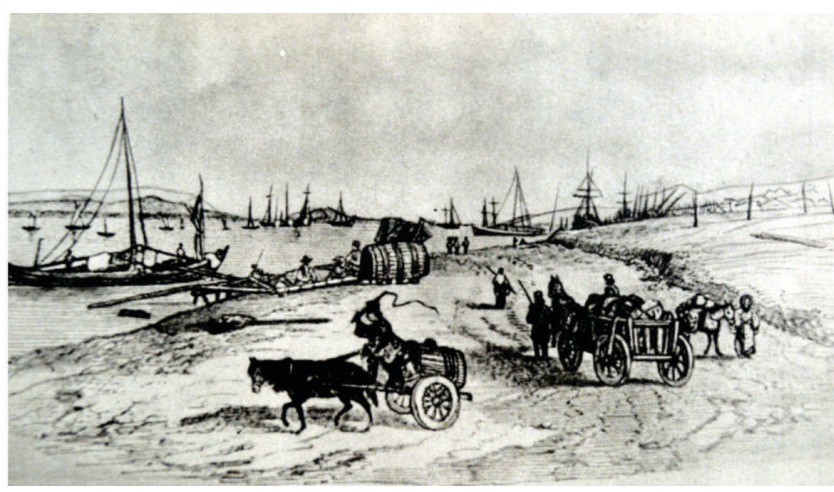

Vista sobre o porto - 1800 
As primeiras referências históricas a Braila surgem em documentos de 1368, período após o qual a cidade rapidamente se transformaria no porto mais importante da Munténia/ Valáquia. Em 1540 foi conquistada pelos Otomanos, que a incorporaram no sistema administrativo e defensivo turco. Fator determinante na evolução da urbe foi a construção pelos Otomanos, no século XVIII, de um sistema defensivo constituído por cinco grandes muralhas concêntricas. Em 1828 Braila voltou para as mãos da Valáquia, facto que inaugura a sua história moderna. O primeiro grande plano concebido para a cidade é de 1834 e deve-se a Rudolf von Boroczyn. A ideia principal do plano de Boroczyn consistiu em regularizar o desenho da muralha exterior, que circundava o povoamento setecentista, acrescentando um anel periférico em que abundavam os espaços verdes. O resultado foi uma moderna avenida, porventura a primeira dos Principados Romenos. Deste modo, o padrão geral assemelha-se, hoje, a um vasto semicírculo abrindo-se para o Danúbio, que aqui se apresenta largo. O plano previa ainda a criação do Jardim Público e da praça central (de forma quadrada), o embelezamento da zona das docas, e ainda a demolição da cidadela otomana e o loteamento dos terrenos assim libertados. Corrigiu-se a orientação das ruas antigas e outras ruas foram abertas, conferindo-se à cidade um aspeto quase geométrico, ao mesmo tempo que esta se expandia para lá do fosso da muralha antiga.

O núcleo do porto moderno fixou-se na zona inferior da cidade. O plano foi criado graças ao prolongamento parcial de uma estrutura mais antiga e bastante difusa. Os efeitos desta medida, que acabou por garantir a preservação de alguns traços, ainda podem ser observados, principalmente na parte situada a sudeste, junto ao Danúbio. A estes passos iniciais sobrepor-se-iam as ações de modernização, as quais vieram definir todo o conjunto da estrutura urbana, imprimindo-Ihe a forma particular que hoje ostenta. Associado ao crescimento demográfico, o paulatino mas espetacular crescimento económico de Braila ao longo do século XIX deu origem a sucessivas expansões da cidade, concretamente em 1855 e 1870. Manteve-se, no entanto,

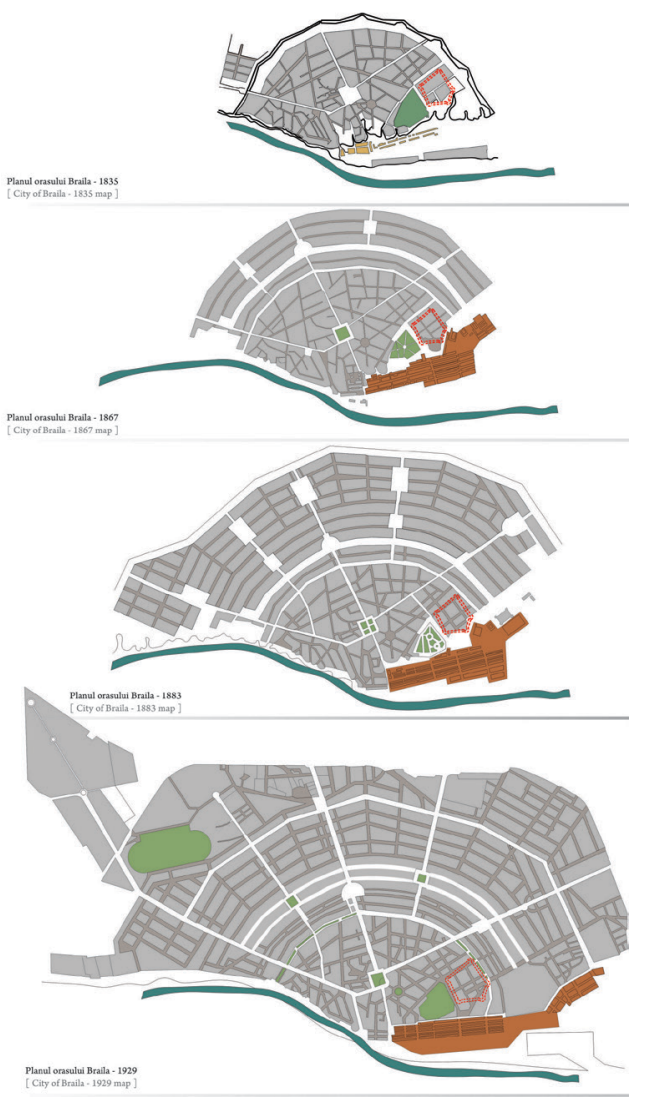

Evolução da cidade (com base em mapas antigos) de 1835 a 2012 
a ideia do semicírculo abrindo-se ao Danúbio, com uma estrutura radial e concêntrica, uniforme e bem organizada. A zona do porto foi delimitada no ano de 1879. Por outro lado, entre 1866 e 1891 toda essa área se foi modernizando, incluindo a parte das docas, os armazéns, e o imponente silo. Linhas ferroviárias paralelas servem toda a área de armazenamento, com algumas delas a acompanhar a margem do rio até à imensa fábrica de moagem Violatos (1898). Toda a frente ribeirinha, desde a Fábrica Violatos a sul até às docas situadas a norte, apresenta molhes e embarcadouros para navios de carga e de passageiros.

Todas estas intervenções ocorridas ao longo do século XIX acabaram por definir os traços daquilo que é, na atualidade, a parte mais antiga da cidade. Os casos de expansão posteriores a esse período e até à Segunda Guerra Mundial seguiram, em parte, esta bem organizada estrutura oitocentista, embora nem sempre respeitando a clareza e o rigor da geometria. A frente ribeirinha foi completamente ocupada pelas atividades portuárias e por edificações de tipo industrial ou áreas de armazenamento. No extremo sul, os estaleiros conheceram um desenvolvimento apreciável. A ligação de Braila com a água vê-se, assim, interrompida por dois importantes legados do seu passado industrial: os estaleiros e as docas. Entre as docas e os estaleiros fica o porto, que, com o seu traçado linear, ocupa a totalidade do socalco inferior. Mais tarde, as linhas do caminho de ferro prolongaram-se a sul até ao limite urbano do século XIX, o que implicou que a ligação de Braila com o Danúbio ficasse totalmente cortada, com exceção da Rua do Imperador Trajano e algumas pequenas artérias de pouco significado por onde é assegurado o acesso à zona portuária - ou seja, à gare fluvial, aos cais, aos armazéns e a outros espaços de armazenamento. A Rua do Imperador Trajano, que liga a praça central à frente ribeirinha, abre-se para um espaço amplo - a Praça do Porto, local de estacionamento para os numerosos veículos que aí afluem.

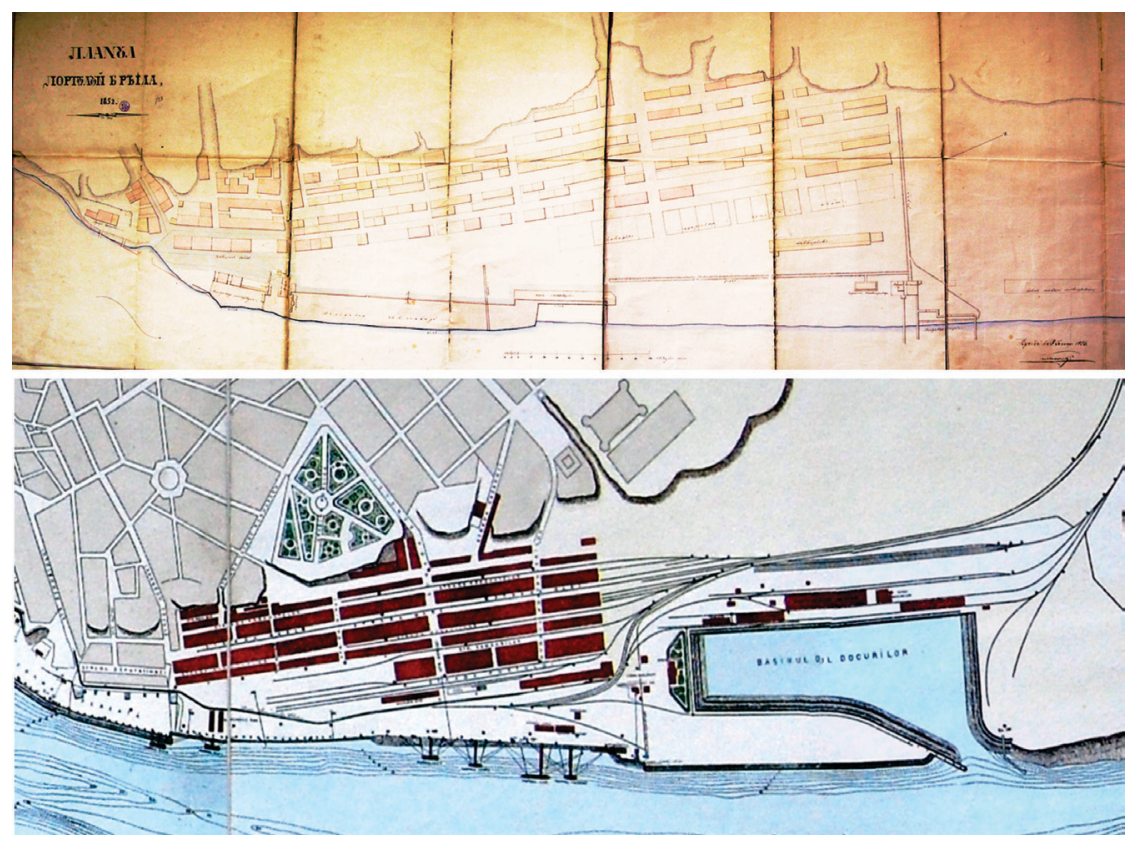

Mapas do porto, datados de 1852 e 1900 
Os processos de expansão da cidade que se seguiram à Segunda Guerra Mundial tiveram lugar ao longo da frente ribeirinha, tanto a norte como a sul, mas também a oeste, para o outro lado da linha férrea. Os sucessivos planos de desenvolvimento urbano empreendidos depois de 1950 procuraram harmonizar as estruturas do século XIX com os inevitáveis imperativos da modernização. Desses projetos, poucos foram os que tiveram em consideração a relação especial que Braila tem como a água. Um deles procede ao prolongamento da Avenida da Independência, a artéria semicircular que passa pelo meio da cidade, até ao limite da sua parte mais alta. Para sul, foi construído o edifício que funciona como sede da administração não só da cidade mas de todo o distrito. A reestruturação desta área permitiu uma ampla abertura em direção ao Danúbio, tendo ainda sido rasgadas vias paralelas em cotas diversas, acompanhando a frente ribeirinha até à Moagem Violatos. É esta, hoje em dia, a única ligação efetiva entre a cidade e o rio, não obstante tratar-se de uma solução que ignora outras relações possíveis entre a urbe histórica e a frente do rio.
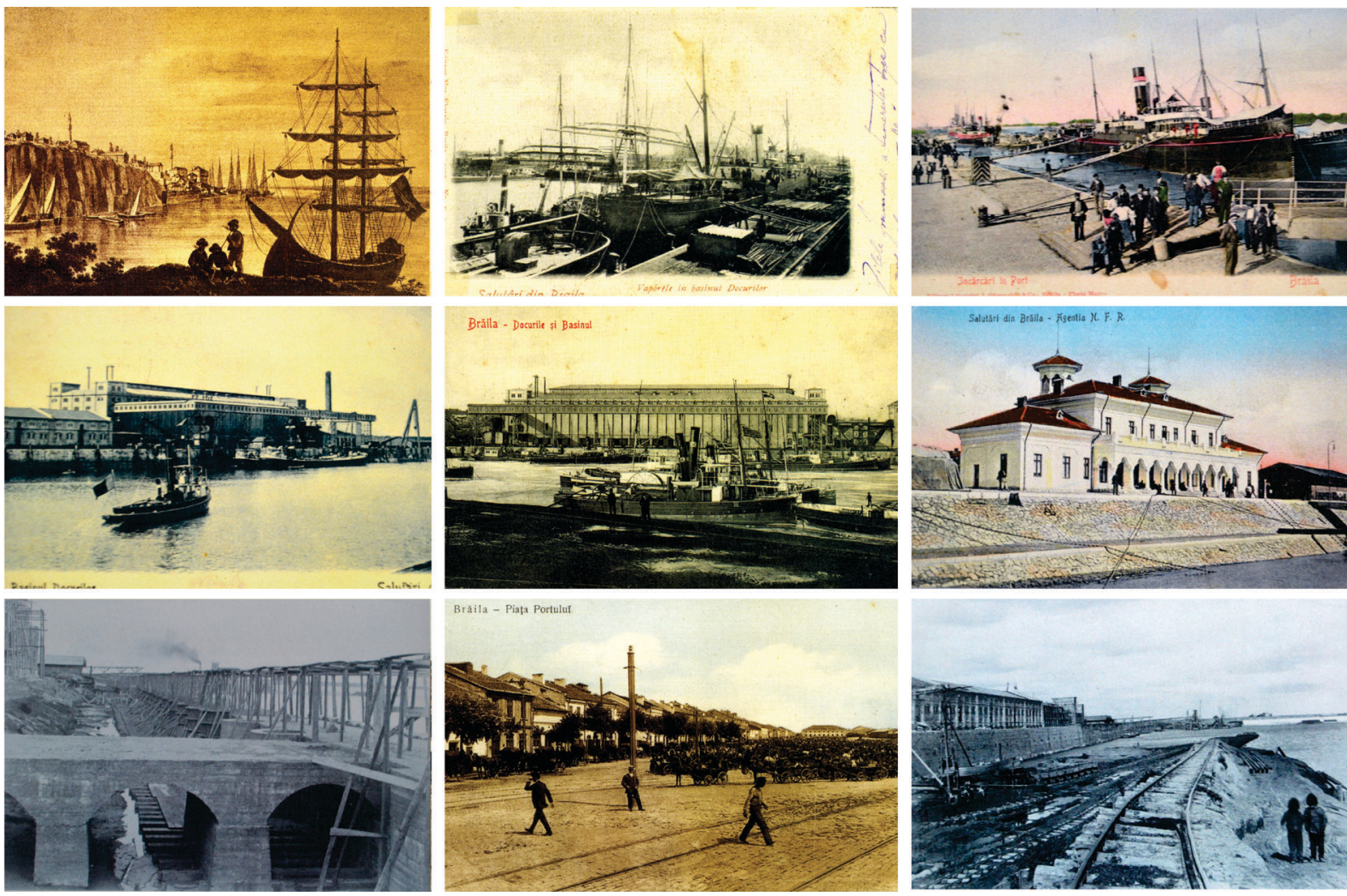

Vistas do porto em diferentes épocas

O património urbano de Braila é composto essencialmente pela sua estrutura urbana, que ficou traçada no século XIX. A estrutura carateriza-se por uma regularidade e uma ordem que não se tornam monótonas, integrando, de uma forma articulada, a velha estrutura não intervencionada. O formato semicircular das ruas oitocentistas, com ampla abertura lateral na direção do rio e com as artérias em disposição radial e relativamente equidistantes entre si, fazem de Braila uma cidade singular no contexto romeno. Contudo, 
também o património edificado é significativo e valioso, contando com edifícios públicos e prédios residenciais de tipologia variada e expressão arquitetónica diversa, que refletem, na sua grande parte, o estilo eclético da época em que foram construídos. Caraterística assinalável, e simultaneamente prova do multiculturalismo de Braila, é o elevado número de igrejas de diferentes credos, como sejam a Igreja Grega (a mais imponente de todas), a Igreja Católica, a Igreja Ortodoxa e a Igreja Lipovana. Uma parte significativa do património edificado está associada às atividades industriais e portuárias que têm lugar na cidade.

Entre os edifícios a referir, os casos mais notórios são as fábricas Violatos (1898) e Lichiardopulos (1910-1912), situadas junto ao rio, que também constituem pontos fortes desta parte da cidade. Igualmente importantes são os silos, concebidos por Anghel Saligny no final da década de 1880. Para além destes, um vasto conjunto de construções e edifícios com as mais diversas funções - oficinas, fábricas, armazéns, depósitos, ou o edificio da administração do porto - acrescenta valor ao património edificado. A presença deste património levou à classificação do conjunto do centro urbano, incluindo o porto, como "centro histórico". Em suma, todos estes aspetos contribuem para o reafirmar da identidade cultural de Braila.

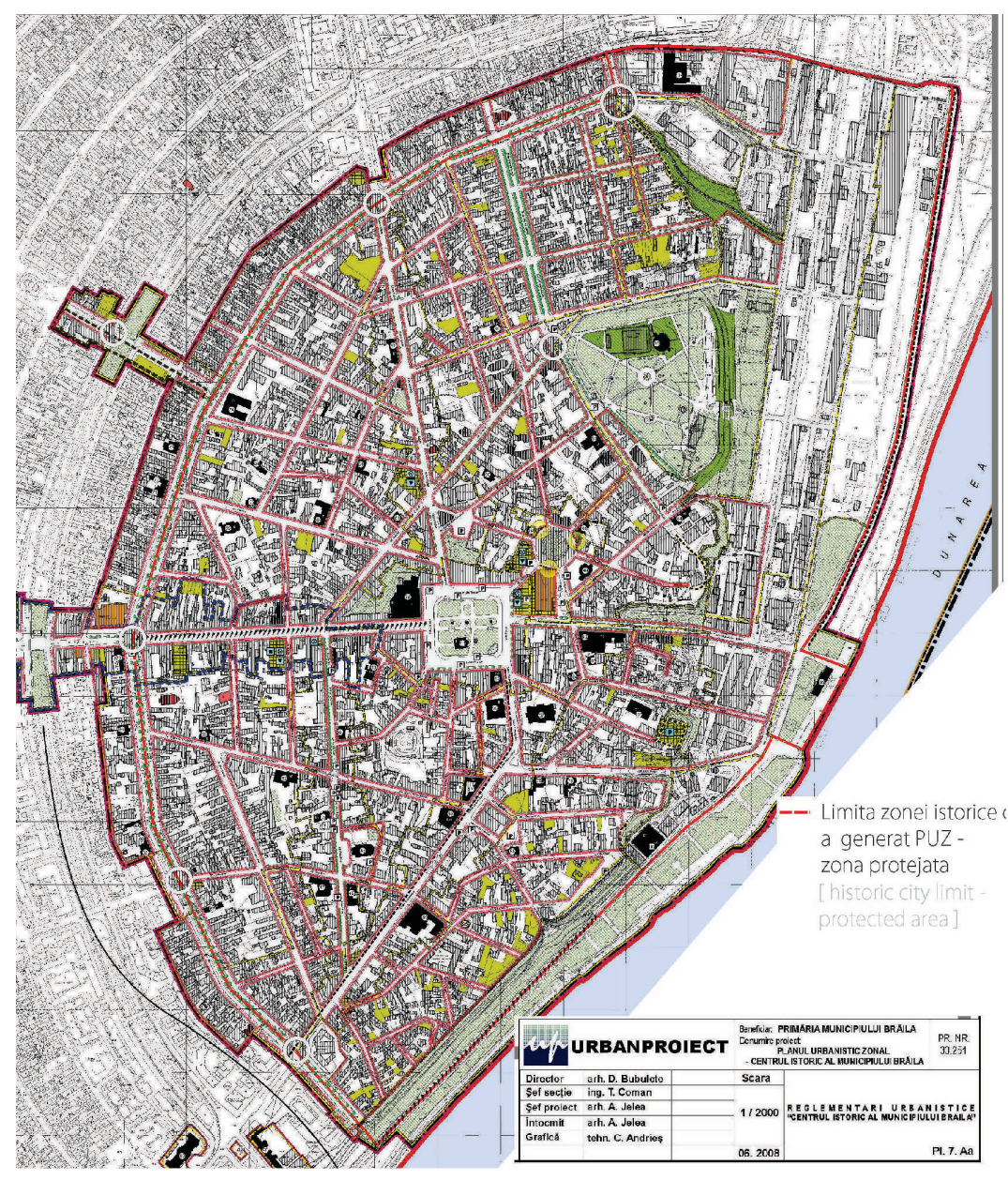

Plano da área protegida - 2008 / Limites da cidade histórica 

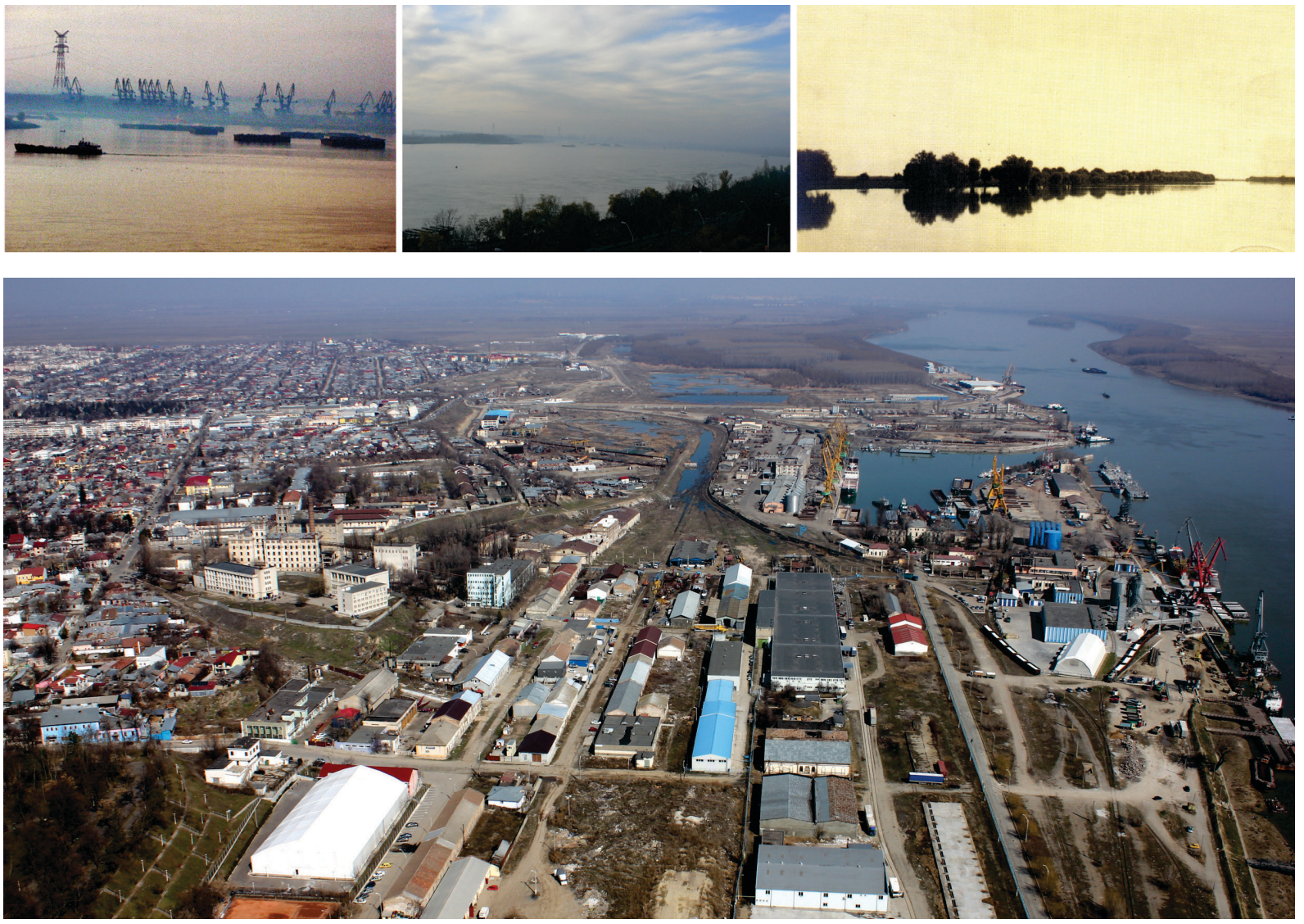

Vista aérea do porto - 2012

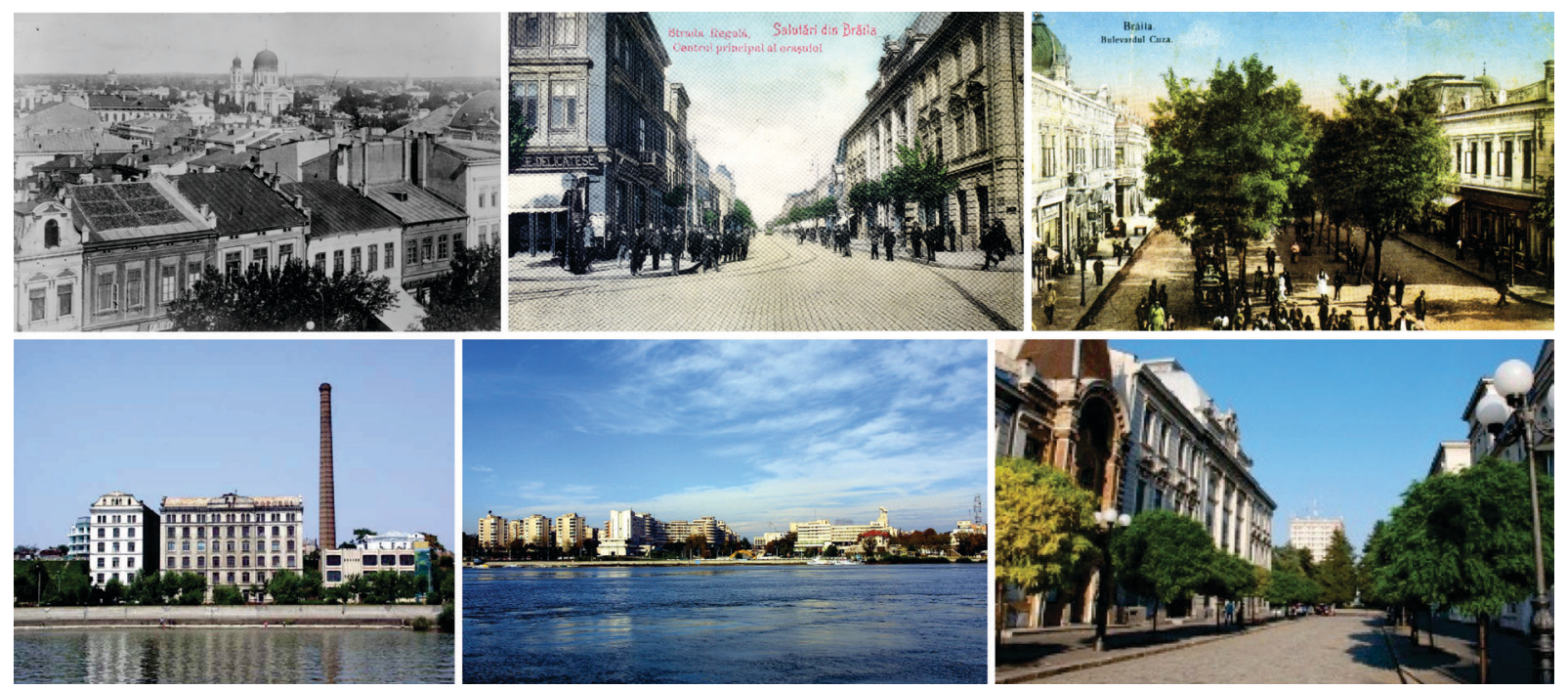

Fotografias diversas da cidade e do rio 


\section{Diagnóstico}

Situada na unidade de paisagem do Baixo Danúbio, Braila é uma componente crucial do futuro sistema urbano de Braila-Galati. A singularidade da sua história ditou-Ihe algumas das caraterísticas no que concerne à relação com a água e com toda a frente ribeirinha. Em primeiro lugar, a configuração geral da cidade - em forma de semicírculo, de que é exemplo único na Roménia, abrindo-se para o Danúbio e acentuando, assim, o papel do rio como limite natural, já que a cidade se desenvolveu apenas na margem esquerda. Em segundo lugar, a localização em dois socalcos e portanto em altitudes diferentes, facto que, se por um lado proporciona, a partir do bordo do socalco superior, amplas vistas sobre o Danúbio e o Paúl de Braila, por outro lado coloca alguns inconvenientes no que se refere à ligação das duas partes da cidade. Em terceiro lugar o uso prolongado do socalco inferior para as atividades do porto e com este relacionadas, incluindo o transporte de pessoas, e também a conceção e apetrechamento, na segunda metade do século passado, de uma extensão linear de passeio localizada na parte sul do centro histórico.

Ao longo dos últimos 20 anos a zona portuária foi afetada por drásticas mudanças. A redução da atividade económica, a reestruturação ou desaparecimento, na zona do porto, de algumas unidades industriais e comerciais, e também a crise económica, conduziram ao abandono de grandes superfícies edificadas - salões, armazéns, etc., algumas delas com uma arquitetura de qualidade, mas que presentemente se encontram num estado de colapso físico - ou, noutros casos, à demolição dos prédios industriais e à sua substituição por edificações de natureza provisória. A alguns terrenos, de dimensão variável, foi concedido o estatuto especial de "zona liberta". Em resultado destas mudanças, a área edificada compacta que existia no século passado, e que é possível ver nas fotografias antigas, acha-se hoje numa situação de desestruturação avançada. Toda esta área está situada na parte norte do centro histórico, onde o socalco inferior se abre como que em leque.

A topografia do terreno, a redução e alteração das atividades portuárias, a qualidade do património industrial, e a multiplicidade de hipóteses para que se desenvolvam, na densidade do território urbano, laços orgânicos entre a cidade e a frente ribeirinha, são fatores que, conjuntamente, apontam para um potencial particularmente complexo, no sentido da reapropriação do elemento água. Para concretizar tal reapropriação deverá promover-se: o prolongamento, até à área das docas, da área de passeio existente (a Promenada); o acentuado reforço da Rua de Trajano como eixo desta área de passeio; o prolongamento - com o respetivo tratamento paisagístico - do jardim público até ao socalco inferior; a reconstrução das estruturas lineares outrora edificadas para fins de armazenamento e atividades portuárias em geral; o prolongamento das instalações da fábrica Lichiardopulos relacionadas com a água, com vista a funcionarem como infraestrutura pública, numa ligação da cidade à frente ribeirinha; e a ligação da cidade à outra margem do Danúbio. 

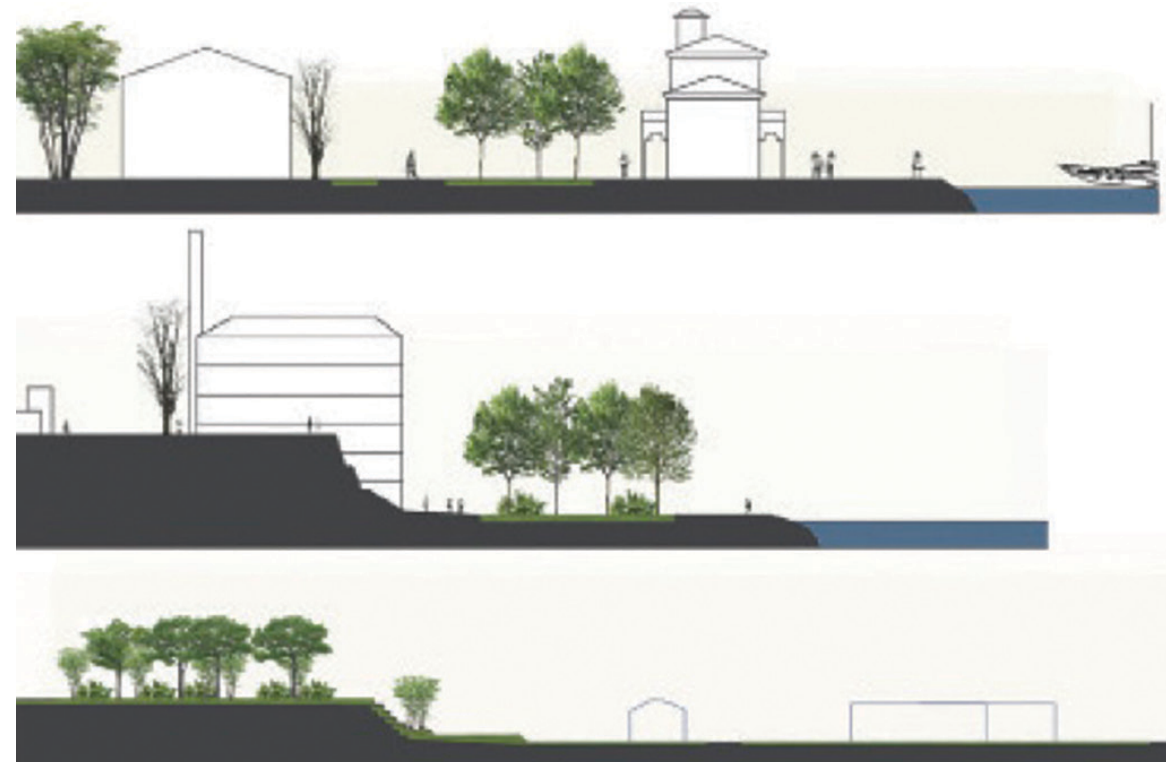

Perfis do terreno correspondentes à situação existente na zona do porto

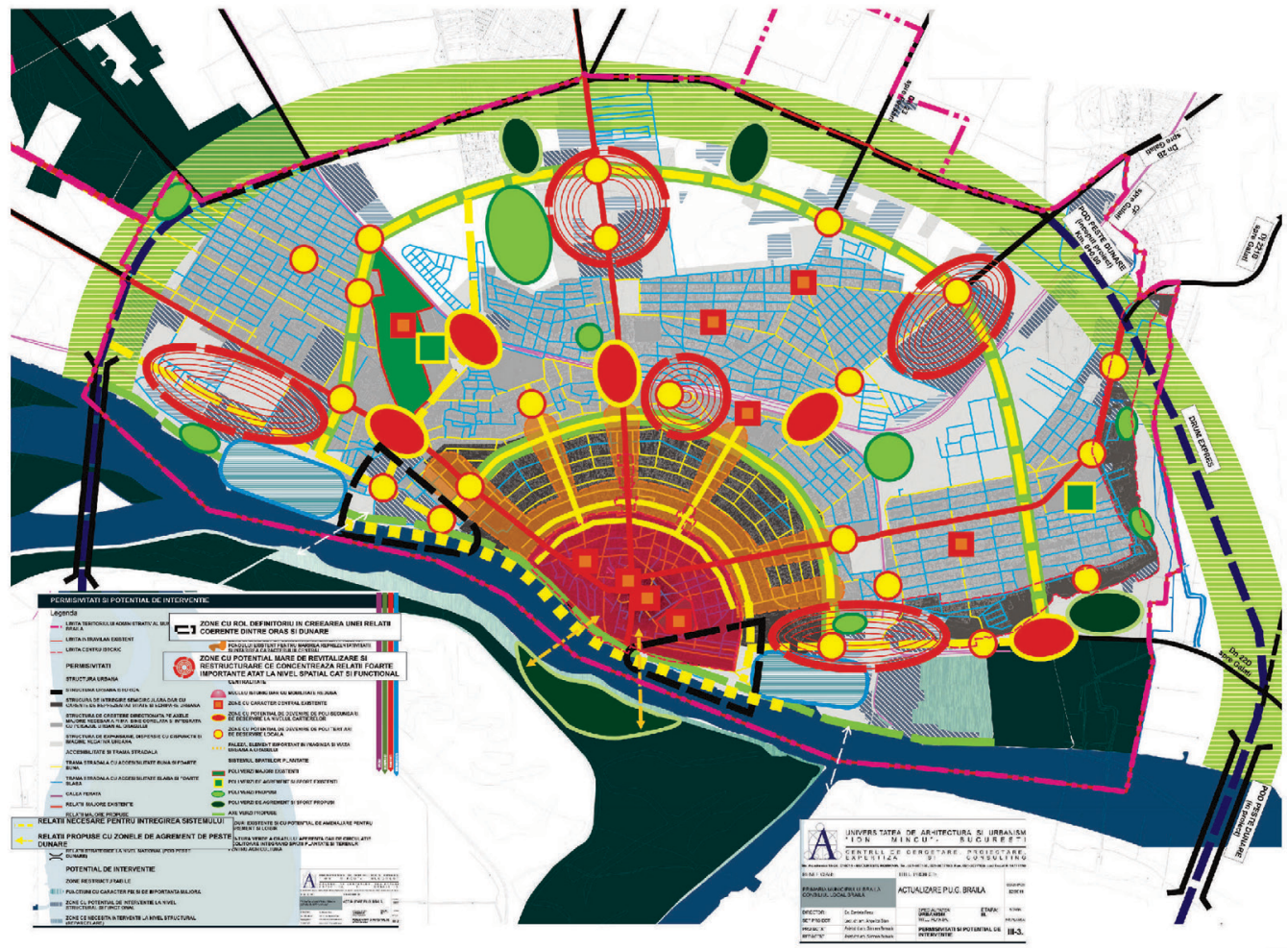

Plano diretor genérico (projeto em curso) - área com potencial de desenvolvimento 


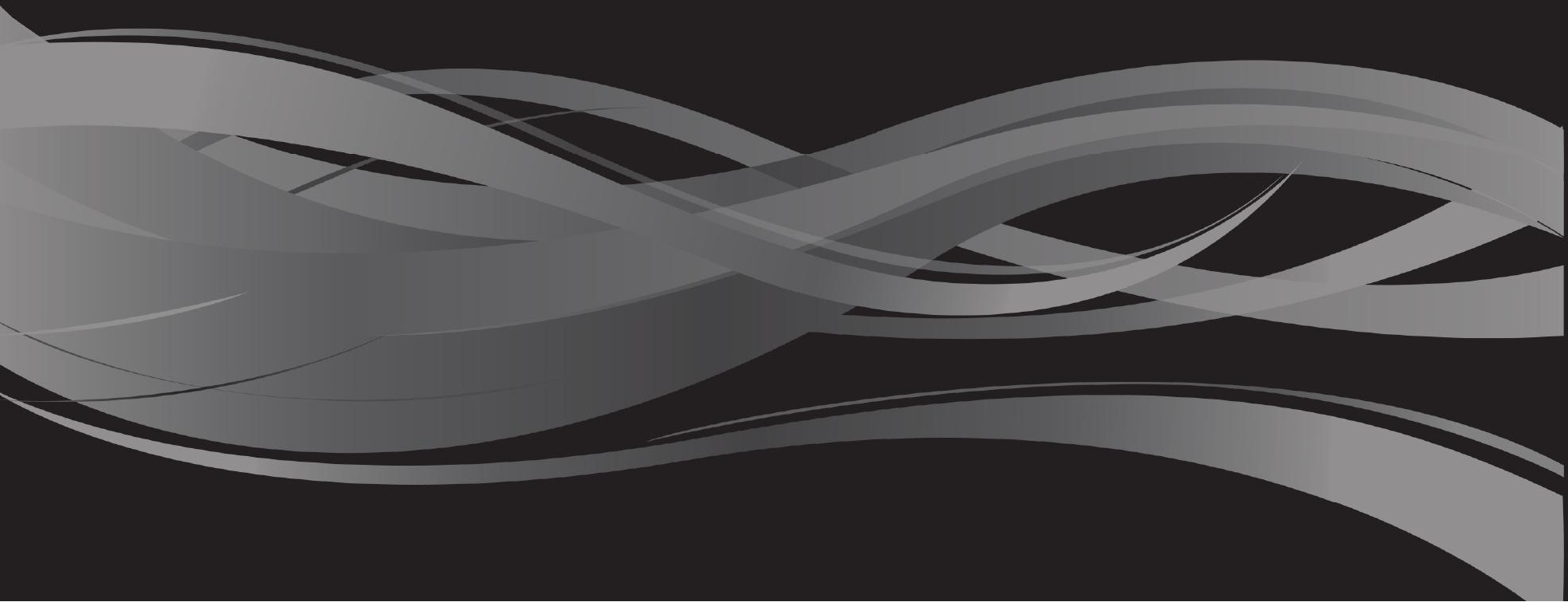




\section{ORIGEM DO NOME}

Os romanos chamavam Munda ao rio Mondego. Munda, é a palavra latina que significa transparência, claridade e pureza. Pode concluir-se que, nesses tempos, as suas águas seriam apreciadas por estas qualidades. Ao longo da Idade Média o rio continuou a chamar-se Munda. Terá sido essa a origem do atual nome do rio, Mondego, que banhava a velha cidade romana de Aeminium.

\section{Rio singular}

O Mondego é, sem qualquer sombra de dúvida, o mais cantado dos rios portugueses por poetas e escritores. Provavelmente deve o fascínio que exerce, há algumas centenas de anos, ao facto de banhar a cidade de Coimbra, onde foi estabelecida, em 1290, uma das mais antigas universidades europeias. A Universidade de Coimbra foi, durante séculos, a única universidade nacional e a única universidade lusófona. Talvez a dívida de gratidão daqueles que foram passando na cidade, para se educarem, experimentando seguramente aí outras lições de vida mais ou menos profanas, explique a sensibilidade com que quase sempre trataram as águas do Mondego, com doçura e suavidade, invocando o rio como lugar de musas e fonte de inspiração poética, que dificilmente se pode reconhecer numa aproximação à realidade. O rio sempre se mostrou instável e traiçoeiro, ora ausente, durante o estio, ora torrencial, sobretudo durante as enchentes primaveris e de inverno.

\section{O rio da nascente à foz}

Só muito dificilmente o pequeno regato, ou Mondeguinho, como é carinhosamente conhecida a sua nascente - onde brota, no sítio de Corgo das Mós, no território concelhio de Gouveia -, poderia ser reconhecido como origem do maior rio que corre integralmente em território português. Nasce em pleno Parque Natural da Serra da Estrela, a maior cadeia de montanhas portuguesa, a uma altitude de cerca de 1525 metros, no mais elevado planalto nacional, junto ao lugar das Penhas Douradas. Durante as primeiras dezenas de quilómetros o pequeno ribeiro corre para nordeste, em direção a Espanha, aparentemente contrariando a declinação natural da plataforma continental ibérica, que pende ligeiramente para sul e poente. O rio, de águas claras e por vezes abundantes, percorre as terras mais altas da serra quase impercetível, em leito recortado e estreito, por entre a rica vegetação ribeirinha, no concelho da Guarda. Desce abruptamente para os cerca de 450 metros de altitude perto de Vila Cortês do Mondego, depois de dobrar para noroeste, ao abandonar a área protegida do Parque Natural. Junto à Vila de Celorico de Beira, já a 401 metros, passa finalmente a correr para sudoeste, em direção à costa, e a ser claramente reconhecido como Rio Mondego. Inicia se aqui o seu curso médio, ao longo do Planalto Beirão, cortando rochas graníticas e formações metamórficas. 

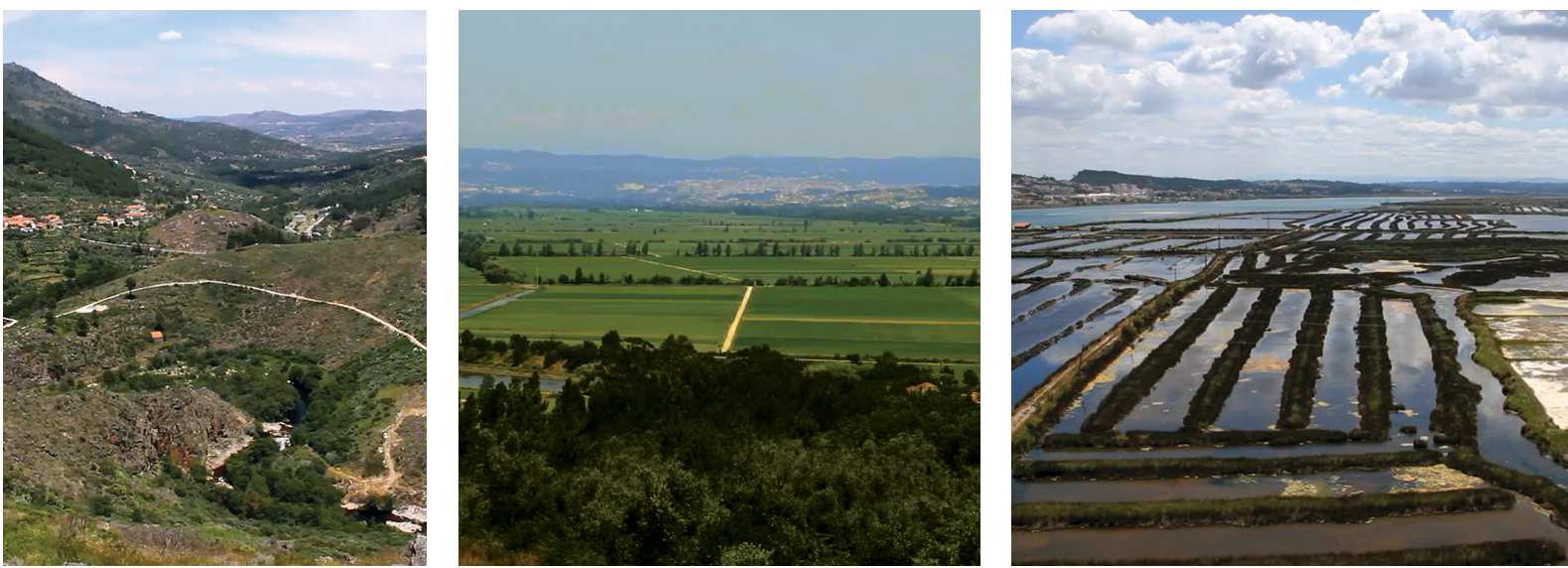

Ao longo do seu percurso total de $258 \mathrm{~km}$ o Mondego recebe as águas de diversos afluentes, sendo o mais importante o Dão, o primeiro afluente relevante, que chega pela sua margem esquerda. As águas dos dois rios fundem-se hoje no enorme lago artificial desenhado pela Barragem Hidroelétrica da Aguieira. Logo depois, juntam-se-lhe as águas do rio Alva, também sobre a margem esquerda, para depois o rio se estreitar de novo num apertado vale, em trajeto caracterizado por numerosos meandros encaixados. Depois de passar aos pés da vila alcandorada de Penacova, que desenha uma interessante praia fluvial - tal como acontece a montante em Ponte Nova, e a jusante noutros desses meandros, que inesperadamente se desenham ao longo da insinuante e caprichosa linha do vale, como em Palheiros/Zorro ou em Pé Rodrigo, e mesmo na Portela - o rio sublima-se na passagem das rochosas Livrarias do Mondego, ou nas Torres do Mondego, que são lugares toponimicamente reveladores da topografia difícil da região. Depois de se libertar das formações xistosas e quartzíticas, já nas imediações da cidade de Coimbra, o rio recebe as águas do rio Ceira na Portela, e aproxima-se por fim da sua secção derradeira. Corre ainda entre as margens urbanas que o confinam mais uma vez, para depois se espraiar definitivamente na ampla planície aluvial do Baixo-Mondego.

O rio inaugura aqui o seu curso inferior, constituído pelos últimos quarenta quilómetros do trajeto, cumprindo um pequeno desnível de apenas 40 metros de altitude. Ao longo desta última etapa a bacia hidrográfica é larga e irregular, insinuando-se transversalmente nos inúmeros vales confinantes. O rio percorre e corta os concelhos de Coimbra, Montemor-o-Velho e Figueira da Foz, até desaguar no Oceano Atlântico. Esta secção final é agora maioritariamente percorrida num curso artificial, e o leito central desenha-se entre diques e canais de rega, perto dos velhos leitos naturais, variáveis e incertos, do antigo encanamento do século XVIII, e do chamado Rio-Velho. É por aqui que se lhe juntam as águas do Arunca, do Ega (ou Rio dos Mouros) e do Pranto, que são os afluentes mais significativos neste troço, e que correm e se aproximam pela margem esquerda. Pelo caminho, o Mondego banha os campos do velho burgo histórico, outrora integralmente muralhado, de Montemor-o-Velho, e atravessa importantes territórios agrícolas extremamente férteis, onde se localizam alguns dos mais produtivos e extensos arrozais da Europa, antes de cruzar a área do salgado. 
No final do percurso forma-se um estuário com cerca de $25 \mathrm{~km}$ de comprimento e, nos seus últimos $7,5 \mathrm{~km}$, o rio desdobra-se em dois braços. O braço norte é o principal e banha diretamente a frente ribeirinha da cidade da Figueira da Foz, onde inicialmente se estabeleceram as instalações dos portos comercial e pesqueiro. Por sua vez, o braço sul, que é muito menos marcado e está profundamente assoreado, recebe as águas do último afluente - o Pranto - antes de se voltar a unir ao leito principal, junto às muralhas do atual porto de pesca da Figueira da Foz. Entre os dois braços forma-se a pequena mas longa llha da Murraceira, definida por inúmeros canais, comportas, tanques e marinhas de sal, e também pelas novas explorações aquícolas, tendo sido laboriosamente construída sobre as ínsuas pré existentes e preservada pelo trabalho hercúleo de marnotos e salineiros, ao longo de séculos de exploração gloriosa e rica do precioso cristal.

O salgado da Figueira está muito abandonado e são hoje poucas as antigas marinhas de exploração de sal que se mantêm ativas. Os traços mais ou menos arruinados deste tipo de organização industrial, de teor e exploração marcadamente artesanais, estendem-se sobre a margem esquerda do rio - no lugar de Armazéns de Lavos, onde a Câmara Municipal sustenta também uma pequena unidade museológica e de exploração ambiental - e, sobretudo, na llha da Murraceira, que se constitui como uma rara e fascinante paisagem artificial. É ela que define a imagem única do estuário, em que o rio se expande antes de desaguar no oceano, pelo meio dos molhes de proteção da barra marítima do importante Porto Comercial da Figueira da Foz.

\section{A biodiversidade do Mondego}

O Mondego é bem conhecido pela pureza das suas águas, que alimentam uma enorme variedade de ecossistemas, desde os da sua montanha original até aos das planícies alagadiças das cotas baixas e, finalmente, aos das áreas estuarinas junto ao oceano. Essas águas suportam uma vida selvagem variada, onde se destacam os répteis, os anfíbios e as aves, alimentando também as colheitas e os pastos da fauna agro-pastoril.

O rio constitui um convite permanente à pesca de recreio, à natação e à náutica ligeira, ao longo de toda a sua extensão. No estuário, junto à foz, destaca-se o ambiente naturalmente protegido da Ilha da Murraceira, onde a tradição industrial de produção de sal marinho, de base artesanal, subsiste em harmonia com os pássaros da orla costeira, que aí nidificam. As novas aquaculturas e a reinvenção dos sistemas produtivos tradicionais estão a ser pensadas, e irão fazer-se lentamente, acautelando a preservação destes sensíveis equilíbrios ambientais.

Relativamente ao que é específico da qualidade da vida aquática, há a distinguir duas zonas principais: o troço superior do rio, com bons níveis de qualidade da água, proporcionando a manutenção das comunidades biológicas aquáticas com características próximas de uma situação pristina; e a região do Baixo Mondego, com acentuada degradação da qualidade da água.

No que respeita ao estado de conservação da vegetação ripícola, pode verificar-se que, em apenas cerca de um terço da extensão total do rio, ela se pode considerar muito bem conservada, ou seja, 
apresentando em ambas as margens uma cobertura vegetal bem desenvolvida, estando aí presentes os estratos arbóreo e o arbustivo.

Como é comum neste tipo de ambientes, entre os principais fatores de perturbação registam-se a degradação e destruição dos ecossistemas aquáticos e terrestres, associada ao desenvolvimento urbano e industrial, ao desenvolvimento agrícola, à construção das barragens e à extração ilegal de areias, e ainda a algumas atividades lúdico-recreativas. Também a atividade florestal, os incêndios, a invasão de espécies exóticas, a caça e a pesca se podem considerar nocivas, ainda que estejam consideravelmente reguladas.

No troço do Baixo Mondego surgem importantes matas de choupos, ulmeiros e salgueiros, de que a mais emblemática é, sem dúvida, a Mata Nacional do Choupal, às portas de Coimbra. Aqui nidifica a maior colónia urbana de milhafre-preto (Milvus migrans) da Europa, com cerca de 70 ninhos recenseados.

Existem diversos locais de interesse ornitológico, como a já referida ilha da Murraceira, e no estuário é comum observarem-se espécies como o pato-real (Anas platyrhynchos), a cegonha-branca (Ciconia ciconia), o flamingo-comum (Phoenicopterus roseus), o alfaiate (Recurvirostra avosetta), a gaivota-prateada (Larus argentatus), o pernilongo (Himantopus himantopus) e a andorinha-do-mar-anã (Sterna albifrons). Devido à sua importância ecológica como zona húmida de nidificação e/ou de alimentação de numerosas espécies de aves aquáticas, o Estuário do Mondego foi classificado como sítio da Convenção de Ramsar, um habitat de importância internacional, não só pelas mencionadas espécies de aves, mas também pela existência das espécies piscícolas migratórias. Algumas destas têm particular importância do ponto de vista conservacionista e comercial, nomeadamente o sável (Alosa alosa), a savelha (Alosa fallax), a lampreia (Petromyzon marinus), e a truta (Salmo truta fario). A construção do sistema de açudes e barragens ao longo do rio veio constituir, apesar dos esforços para a mitigar, uma barreira agravada à passagem destas espécies migradoras. Na zona a jusante do Açude de Coimbra encontram-se exclusivamente espécies que sobrevivem a uma potencial influência salina.

Na Serra da Estrela encontra-se o raríssimo Melro-d'água (Cinclus cinclus) entre muitas outras aves comuns, mas são aí relevantes várias outras espécies, nomeadamente anfíbios, sendo alguns deles raros e endógenos.
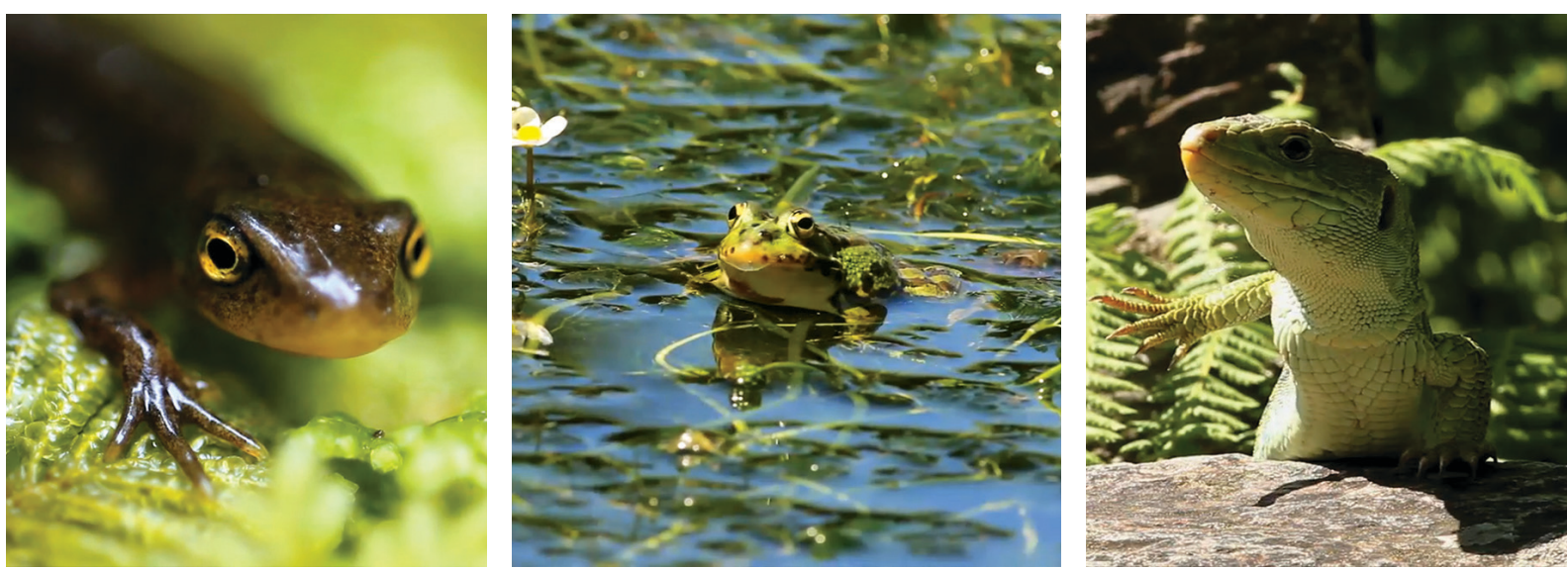
O Mondego é uma lição de biodiversidade de que só recentemente se está a ganhar consciência. A divulgação e pedagogia da sua complexidade e beleza ímpares deverão ser alvo de programas de sensibilização e exploração ambientais nos próximos anos. Hoje, pode apenas assistir-se a um conjunto de iniciativas isoladas de carácter voluntarista, de que se pode destacar a criação do Parque Patrimonial do Mondego, que claramente se propõe redefinir uma área bem mais ampla do que aquela que aparece classificada e protegida pela tutela oficial do Instituto de Conservação da Natureza e das Florestas. Também na definição dos Percursos da Natureza de Coimbra, sob tutela da Câmara Municipal de Coimbra, se apresenta um esforço de reconhecimento e valorização patrimonial do Mondego, em paralelo com outros valores ambientais e ecológicos da região.

\section{Limite (fronteira) administrativo regional}

Depois de atravessar o concelho de Fornos de Algodres, o rio serve de fronteira entre os distritos de Viseu, a norte, e da Guarda e de Coimbra, a sul, para depois passar a cruzar parcialmente o último distrito antes de chegar à costa. Assim, ele delimita, na margem norte, os concelhos de Mangualde, Nelas, Carregal do Sal, Santa Comba Dão e Mortágua, enquanto na margem sul serve de fronteira aos concelhos de Gouveia, Seia, Oliveira do Hospital, Tábua, Penacova e Vila Nova de Poiares. Por fim, corta os concelhos de Coimbra, Montemor-o-Velho e Figueira da Foz, antes de desaguar no Oceano Atlântico.
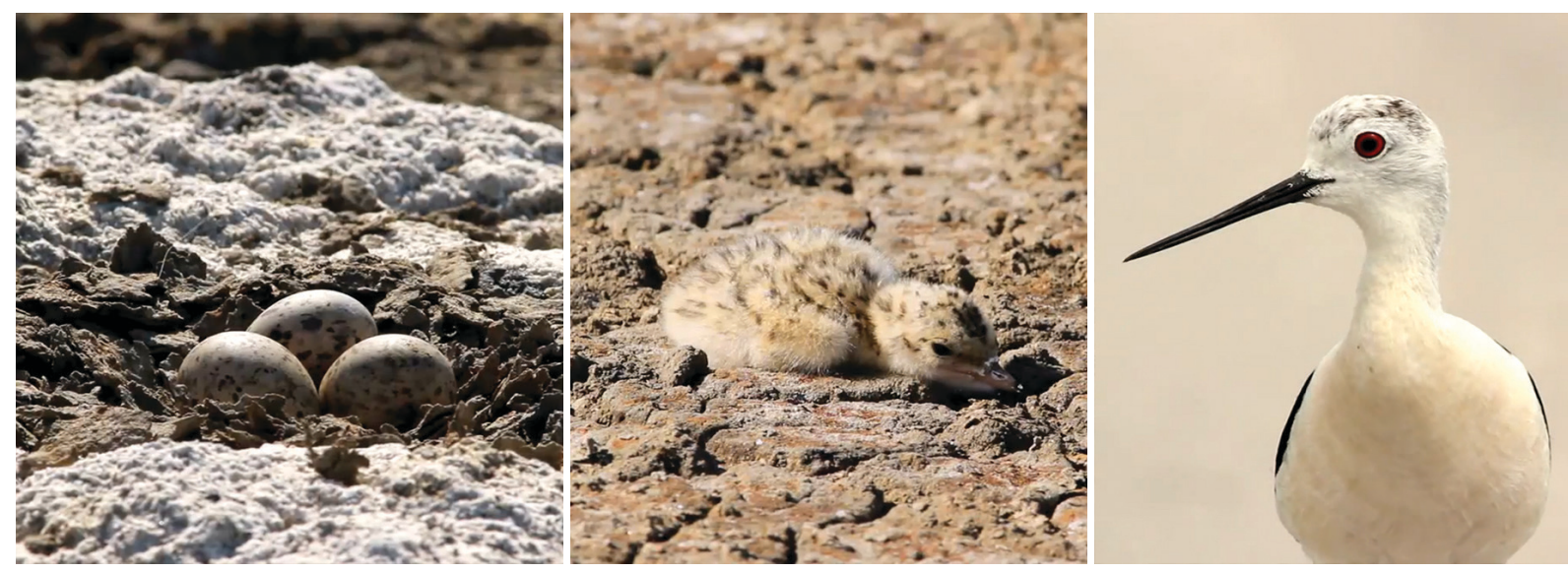

\section{Bacia hidrográfica e cheias}

O Mondego drena uma região muito ampla - a sua bacia hidrográfica ocupa o segundo lugar em área, com uma extensão total de $6645 \mathrm{~km}^{2}$, entre as dos rios que se situam totalmente em território português -, escavada e abrupta, entre vertentes de sucessivas montanhas, e em territórios 
de pluviosidade muito significativa. Acrescenta-se a este quadro o conjunto dos seus principais afluentes que, invariavelmente, mesmo sendo menores, são como ele rios ou ribeiros alimentados pelas águas e torrentes de montanha, e do degelo pós-invernal. Define-se assim um padrão de imprevisibilidade nada fácil de controlar, devido à estreiteza do leito do chamado Alto Mondego que, em alguns troços do curso médio, se faz através de um vale bastante encaixado, que acelera as águas e as precipita violentamente. A bacia hidrográfica regista uma precipitação média anual de $1233 \mathrm{~mm}$ e um caudal médio anual de 108,3 m³/s. As águas chegam em tempos muito curtos às margens banhadas da cidade de Coimbra, ou mesmo à planície aluvionar do Baixo Mondego, onde o rio sempre deixou marcas intempestivas das suas tumultuosas passagens. São históricas as datas de grandes cheias, que espalharam o terror e o caos, para além da miséria decorrente dos estragos nas colheitas dizimadas, ou do gado perecido.

A causa principal da ocorrência das cheias é a incidência de precipitações intensas, associada à dimensão da bacia hidrográfica, que governam as suas características e que, no rio Mondego, as fazem relativamente rápidas, com tempos entre o início de cheia e o pico do caudal da ordem das poucas horas, podendo ser particularmente perigosas devido ao aumento brusco do nível de escoamento.

As cheias no rio Mondego estão registadas, pelo menos, desde o século XIV, afetando a vida da importante cidade de Coimbra. Aí foi possível registar as datas mais importantes, das quais se destacam os anos de 1331, 1788, 1821, 1842, 1852, 1860, 1872, 1900, 1915, 1962, 1969 e 1979, 2001 e, ainda que sem consequências graves, a de 2012-13 e a de 2016. Numa avaliação empírica da frequência pode verificar-se que as cheias designadas como importantes tiveram um período de retorno reduzido e decrescente, sobretudo nos dois últimos séculos. Tornou-se evidente, no século $X X$, a necessidade de uma intervenção importante para controlar as águas.
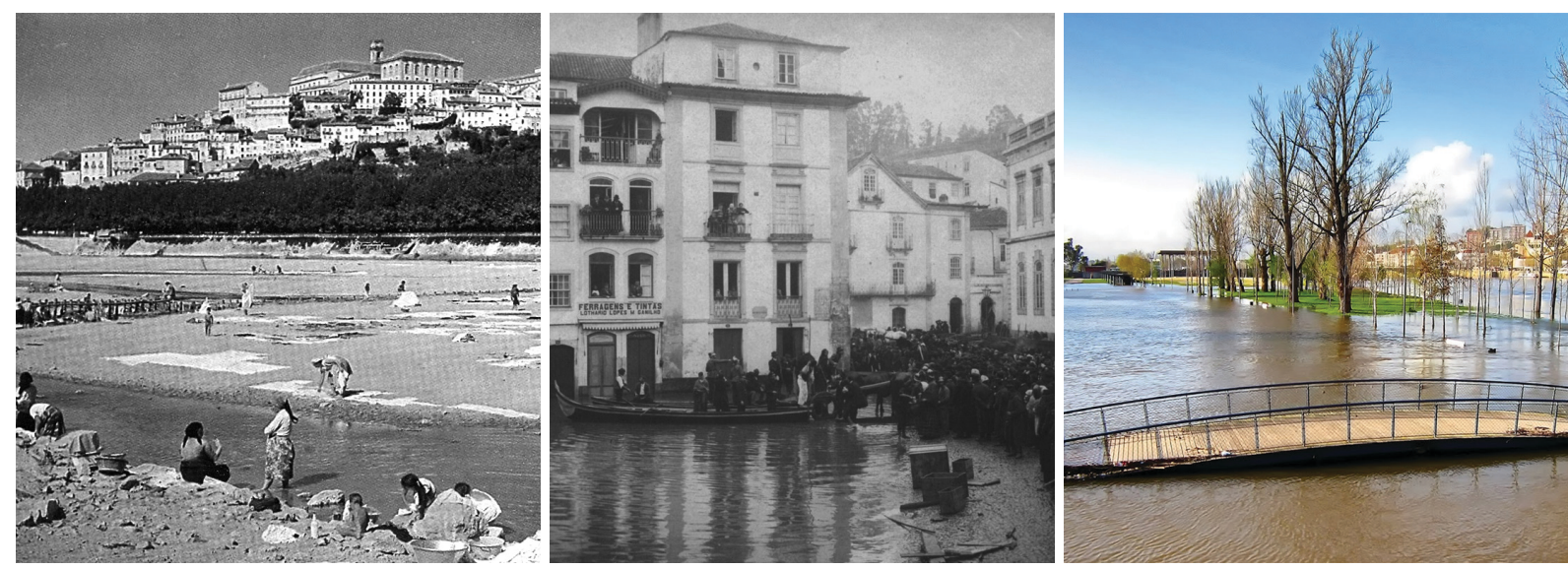

Os caudais de cheia em Coimbra eram da ordem dos 2500 m³/s, sendo amortecidos para 1200 $\mathrm{m}^{3} / \mathrm{s}$ através dos aproveitamentos hidráulicos da Aguieira e da Raiva, seguidamente referidos. Na foz estão hoje previstos caudais de cerca de 3000 m³/s. 


\section{Navegação e pontes}

Os dados disponíveis permitem supor que houve uma evolução da navegabilidade no Mondego desde a ocupação fenícia. Talvez durante a ocupação Romana os navios de mar ainda chegassem próximo de Coimbra, mas o progressivo assoreamento terá reduzido toda a navegação, especialmente para montante da cidade, exigindo barcos de menor porte. Mais tarde, as barcas serranas ter-se-ão transformado no meio de transporte privilegiado no contacto entre o interior e o litoral. Vinham do Oceano Atlântico até Coimbra e, para montante, barcas mais pequenas chegavam a ir mesmo até Penacova. Esta navegação servia sobretudo para que as mulheres (lavadeiras do mondego), de Penacova e de outros lugares, viessem a Coimbra buscar roupa suja, que depois devolviam lavada e passada a ferro; serviam também para os homens levarem lenha para o litoral e trazerem peixe e sal para o interior.

No século XVII o estuário já só se desenhava a jusante de Montemor-o-Velho, até cerca de 20 km a montante da desembocadura atual. O assoreamento progressivo do leito aumentou a dificuldade da navegação no Mondego, levando ao seu quase total desaparecimento durante a década de 50 do século XX. Calcula-se que nos últimos seiscentos anos o leito do rio terá subido, no seu troço final, cerca de um centímetro por ano, ou seja, um metro em cada século.
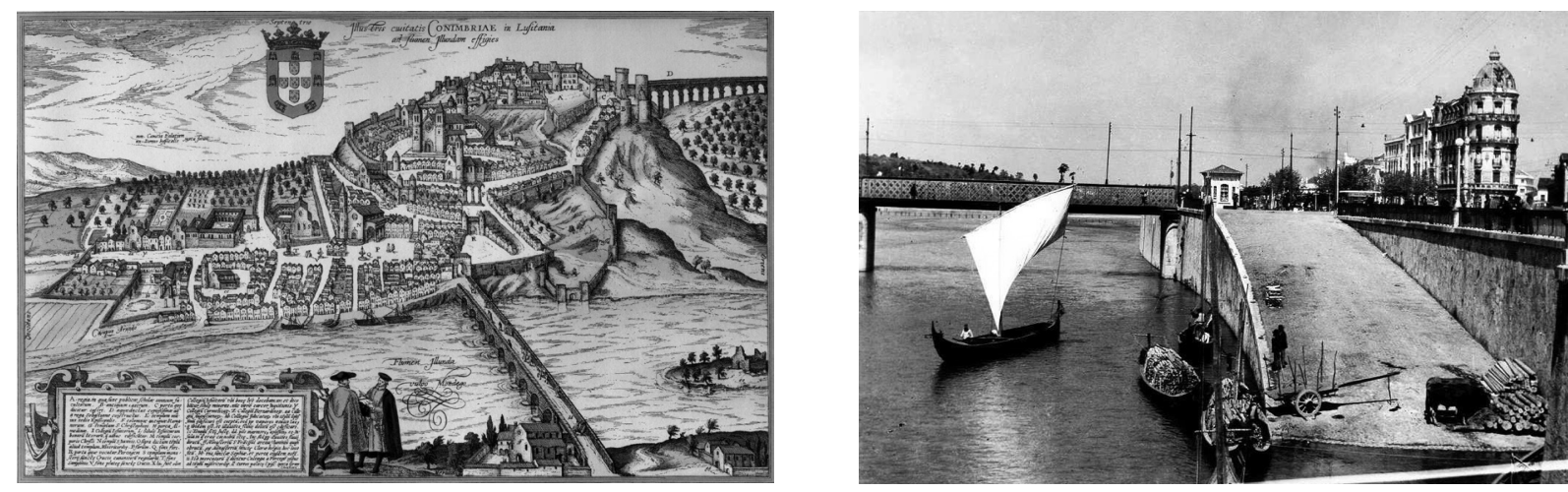

Este processo traduziu-se, para o sítio de Coimbra, num conjunto de intervenções sucessivas na importante travessia fluvial, e principal ligação existente entre o sul e o norte do país, materializada na Ponte de Santa Clara - ou nas sucessivas pontes que aí terão existido. Está estudada e documentada a subida progressiva do nível dos tabuleiros, que terão sido elevados pelo menos seis metros, desde o registo da ponte construída - possivelmente apenas reparada, sobre a estrutura de uma velha ponte romana pré existente -, por D. Afonso Henriques, primeiro rei português, em 1132 (Alarcão, 2012: 18) reconhecendo a sua importância como elemento de ligação entre o norte e o sul do novo reino. Uma torre de portagem rematava a ponte no extremo do lado da cidade.

Os séculos que se seguiram foram de luta constante contra o aumento do nível das águas e do assoreamento do rio. De tal modo que, em 1513, por ordem de D. Manuel, uma nova ponte foi construída sobre os pegões da primeira, alteando-se o tabuleiro cerca de 5 metros (Alarcão, 2012: 24 e 
45). Também uma nova torre seria construída do lado de Coimbra. No final de Quinhentos terá sido estabelecido o "O" da ponte, espécie de pequena rotunda, do lado oposto à cidade.

A ponte manuelina seria demolida para dar lugar a uma ponte metálica sobre pilares de pedra, inaugurada em 1875.

A elegante ponte atual, "Ponte de Santa Clara", projeto do Eng Edgar Cardoso, data de 1954. Todas as outras pontes, a montante e jusante de Santa Clara, nas imediações da cidade, mantiveram um carácter pedonal e efémero, sendo reconstruídas em cada ano após as cheias que sistematicamente as destruíam.

Outras, mais recentes, são o açude-ponte, de inícios dos anos 80 (a jusante) e a ponte Rainha Santa Isabel de 2004 (a montante), ambas predominantemente rodoviárias. Há ainda a belíssima ponte pedonal Pedro e Inês, de 2006, projeto dos engenheiros Adão da Fonseca e Cecil Balmond, ligando ambas as margens do Parque Verde.

A ponte ferroviária, junto da mata do Choupal, existe desde finais do século XIX.

As sucessivas pontes e as margens urbanas terão refletido ao longo dos séculos a subida do leito do rio, respondendo ao assoreamento e procurando proteção para as investidas, cada vez mais preocupantes, das águas.

\section{Projetos de regularização do baixo Mondego}

O assoreamento do rio entre Coimbra e o mar foi uma realidade a partir de finais do século XIII, sobretudo devido à deflorestação das encostas a montante, para efeitos de subsistência agrícola, após a conquista da nacionalidade.

Em Coimbra os antigos conventos de Santa Ana, S. Domingos, S. Francisco e Santa Clara-a-Velha, foram afetados pela subida das águas do rio, dos quais apenas o último edifício subsiste, podendo as ruínas ser visitadas num moderno centro de interpretação.

Vários reis se preocuparam com as defesas contra as enchentes do rio, em particular na cidade de Coimbra, desde D. Manuel a Filipe III.

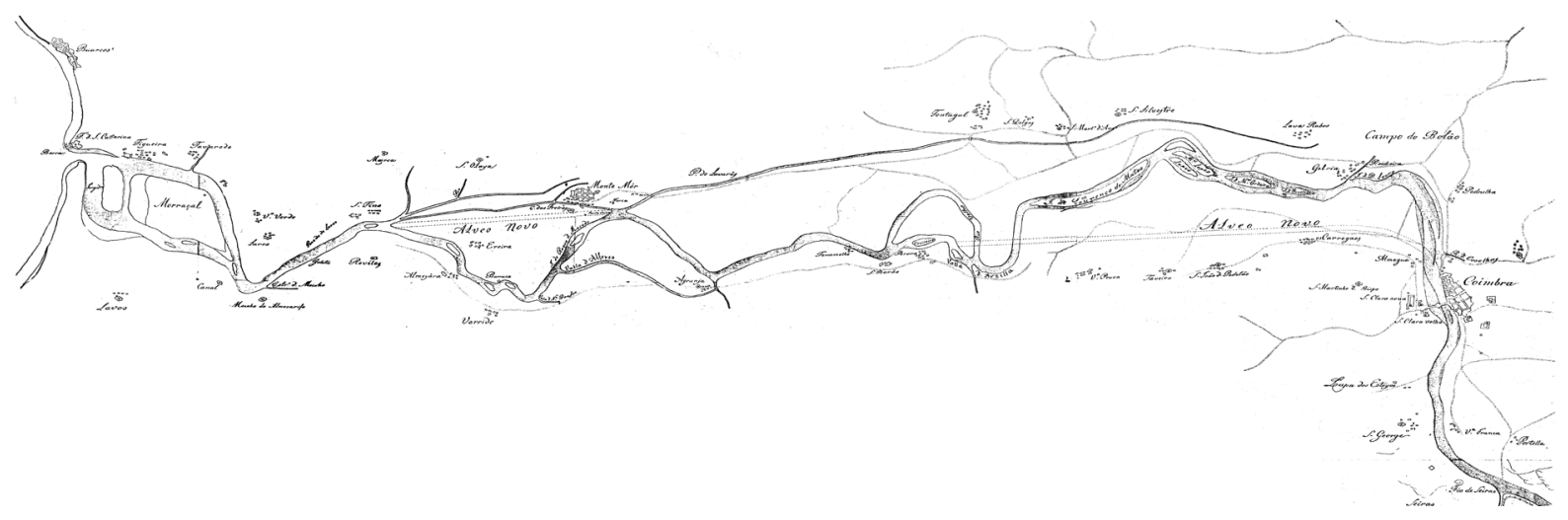


Em 1684, D. Pedro II incumbiu o reitor da Universidade de proceder à realização de um plano de encanamento do baixo Mondego. Parece ser consequência desta iniciativa a realização da magnífica planta, realizada pelos engenheiros Manoel Mexia da Silva e Manuel de Azevedo Fortes em 1703, que mostra o rio desde Coimbra à Figueira da Foz. Propõe-se a abertura de dois canais em linha recta ("alveo novo") com o fim de atalhar e regularizar o leito do rio.

Esta proposta seria retomada no final do século pelo padre Estevão Cabral, incumbido de realizar novo plano. Nesta ocasião logrou-se realizar obra, sobretudo na fixação de um novo troço rectilíneo entre a quebrada grande (imediatamente a jusante de Coimbra) e Pereira do Campo, cujos trabalhos, começados em 1791, foram interrompidos pelas invasões francesas.

Desde 1781 até 1807 a situação dos campos do Mondego melhorou muito, após a abertura de um novo leito. Mas a situação foi piorando, devido ao assoreamento do rio, chegando ao século XX numa situação insustentável. Foi então preparado o Plano Geral de Aproveitamento Hidráulico da Bacia do Mondego, para intervenção na década de sessenta, que foi implementada maioritariamente desde o decénio seguinte.

A mata do Choupal, que consolida o novo leito do rio, data de final da década de 1860.

\section{Gestão do aproveitamento hidráulico}

A bacia hidrográfica do Mondego apresenta uma enorme diversificação de utilizações da água, que são muito importantes para o desenvolvimento económico da região, nomeadamente, a agricultura, a indústria, a produção de energia elétrica e o abastecimento público de água. Desta multiplicidade de utilizadores decorreu a necessidade de implementação de um modelo de gestão integrada dos recursos hídricos, onde assume principal relevância a definição de um quadro jurídico e institucional, para a criação de uma entidade gestora do Aproveitamento Hidráulico do Mondego.

\section{Aproveitamento hidroeléctrico e hidroagrícola}

Na bacia hidrográfica do rio Mondego localizam-se inúmeros aproveitamentos hidráulicos. A ca-

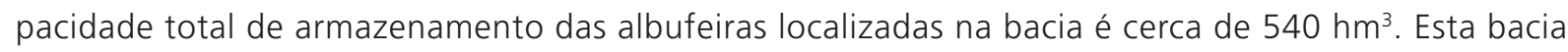
é por isso uma das que tem, em Portugal, maior utilização dos recursos hídricos, sobretudo nas componentes hidroelétricas e agrícola. Destaca-se particularmente o Sistema de Barragens Aguieira/Raiva/ Fronhas, concluído em 1979, com uma potência instalada de 110 MW e uma produtibilidade média anual de $360 \mathrm{GW} / \mathrm{h}$, que regulariza os volumes de água para o abastecimento público de inúmeros concelhos e para a rega, no Aproveitamento Hidroagrícola do Baixo Mondego.

Com efeito, o «Plano Geral de Aproveitamento Hidráulico da Bacia do Mondego» foi apresentado em 1962, tendo-se iniciado a primeira fase de realização cerca de dez anos depois. No seu conjunto a obra contemplou duas grandes barragens - Aguieira e Raiva - e duas menores - a de Fronhas e o 
Açude, em Coimbra, terminado em 1981 - além de novos leitos aluvionares, 7,7 km de diques de proteção e defesa, e canais de rega. Efetuaram-se para o efeito dragagens de cerca de $16 \mathrm{hm}^{3}$ e revestimentos com um volume de $0,5 \mathrm{hm}^{3}$. Deste projeto faz ainda parte um complexo empreendimento de reparcelamento e otimização da exploração agrícola, associando-se ao aproveitamento hidroelétrico o redesenho e otimização de todo o modelo de exploração e aproveitamento hidroagrícola.

Assim sendo, o Mondego corre atualmente num canal artificial desde Coimbra até à Figueira da Foz onde desagua no Atlântico, servindo o seu estuário de porto e de abrigo para as atividades ligadas ao comércio, à pesca, ao sal e às pisciculturas, ao turismo e ao recreio náutico, já referidas.

A realização da obra de controlo e regularização das águas do Mondego viu a sua última fase ser recentemente terminada, apenas em 2012, com a conclusão da Escada do Peixe, associada ao Açude de Coimbra, respondendo aos apelos de inúmeras organizações ambientalistas. Há projetos para mais barragens e aproveitamentos hidroelétricos, sobretudo através de mini-hídricas, que são polémicos por razões de natureza ecológica e ambiental, e que estão temporariamente suspensos.
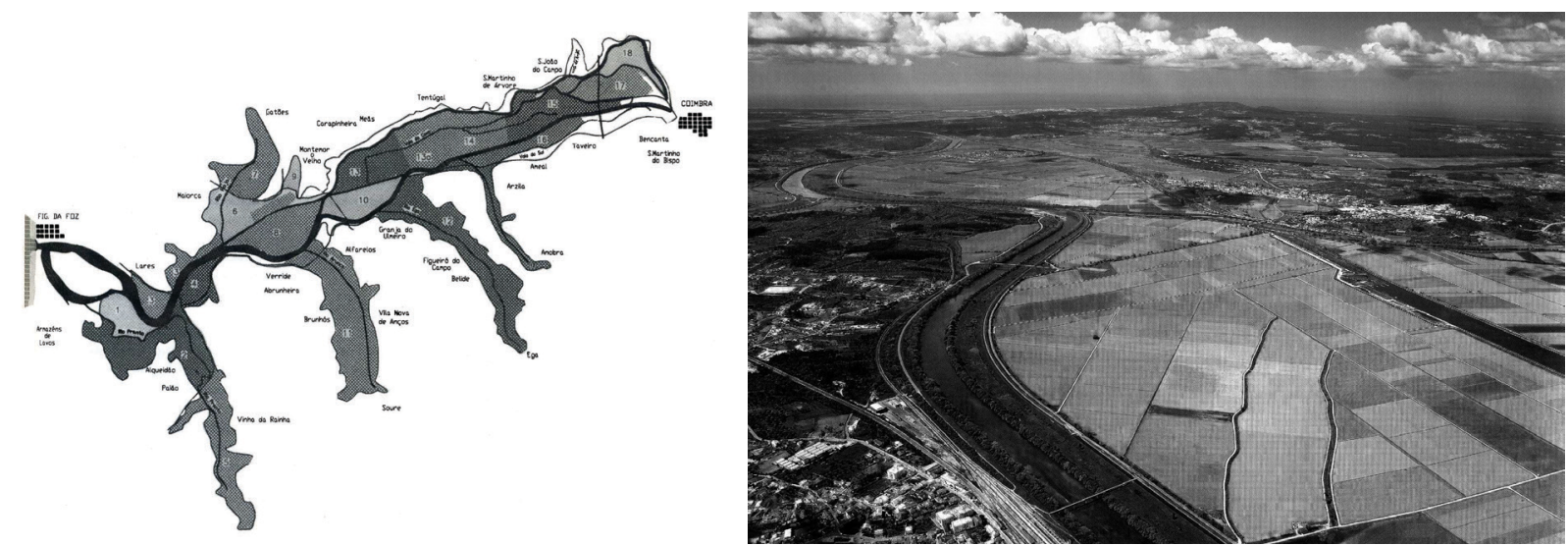

O Projeto de Aproveitamento Hidráulico da Bacia do Mondego, sendo um sonho muito antigo e com uma história técnica longa e bem documentada ao longo de séculos, viu a sua obra perdurar décadas e chegou a ser, em alguns períodos mais recentes (no último quartel do século passado), uma das maiores e mais vultosas obras públicas realizadas pelo estado português.

\section{Espelho de água I Imagem urbana e clima}

Apesar dos inúmeros estudos, projetos e obras anteriores, desenvolvidos ao longo de mais de 200 anos, e dos recentes investimentos realizados, a última enchente grave, com inundação parcial da zona baixa da cidade de Coimbra, ocorreu ainda no Inverno de 2000-2001. Isto após a conclusão do dique urbano - a Ponte do Açude, de 1981 - que, há pouco mais de 30 anos, fixou o atual espelho de água que banha a cidade, mudando-Ihe definitivamente a imagem. 
A alteração no regime de segurança urbana correspondeu também a uma importante transformação do regime climático, reduzindo as amplitudes térmicas urbanas, noturna e diurna, e sobretudo as associadas aos picos estival e de inverno. Também a baixa pressão, que está normalmente associada à presença permanente da água, permite uma melhor ventilação urbana, notável sobretudo na zona baixa ribeirinha.

No entanto, foi a mudança na imagem da cidade que se mostrou mais significativa, pois a alternância entre o imenso areal em que corria um escasso fio de água - conhecido por Basófias - e as violentas enchentes ocasionais de inverno ou primavera, foi afastada. A cidade repousa agora junto ao lago, ou espelho de água, onde se refletem as colinas, hoje construídas em ambas as margens. Tem sido igualmente possível recuperar áreas arqueológicas historicamente relevantes que, tal como a cerca do Convento de Santa Clara-a-Velha, estavam inundadas junto ao rio, e que a cidade fora obrigada a esquecer ao longo de séculos. Nos espaços ribeirinhos têm vindo a instalar-se recentemente novos programas públicos e diversos equipamentos urbanos. Na verdade, muitos investimentos importantes têm sido efetuados sobre as margens, e mesmo sobre o antigo leito do rio - como acontecera antes com o Centro Desportivo Universitário, no final da década de 50. Isto verifica-se particularmente na zona situada a montante do centro urbano, mas, contudo, há ainda muitas áreas residuais que ocupam uma significativa parte das margens urbanas, principalmente as situadas a jusante da ponte de Santa Clara, no tramo que antecede a Ponte do Açude, precisamente onde a antiga proteção das margens se fez sobre aterros que estreitaram o leito e alargaram a área de frente urbana. Este troço corresponde à posição mais tradicional da cidade, sob a margem direita, próxima do atravessamento clássico do rio, desde a fundação da nacionalidade e, provavelmente, desde a própria romanização. A construção dos muros ribeirinhos de proteção, primeiro, reforçada pela instalação, sobre eles, das linhas de caminho-de-ferro e plataformas de triagem ferroviárias, e ainda a sobrepressão industrial, entre os finais do século XIX e as primeiras décadas do século XX, explicam um tipo de ocupações urbanas que alhearam completamente a vida da cidade da frente de rio. Os vazios agora aí existentes são resultado da obsolescência de todas essas edificações e infraestruturas, hoje abandonadas ou desnecessárias, e subaproveitadas, que só novos processos de regeneração urbana poderão sanar.
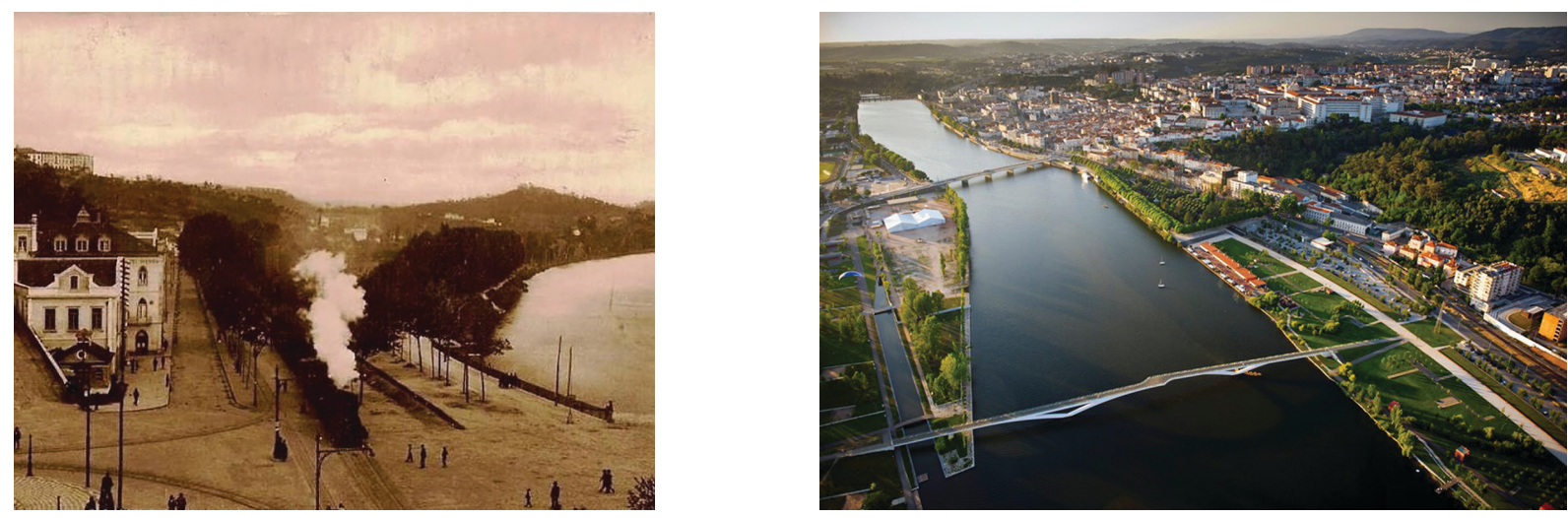
Das velhas imagens históricas do Basófias sem água, e das suas praias urbanas fluviais, que ano após ano ocupavam o leito de cheias durante o estio, para prazer e deleite das classes operárias e estudantes - que aqui faziam o seu desporto, recreio e lazer - restam as memórias e os registos fotográficos. Paradoxalmente, também da praia atlântica da cidade da Figueira da Foz, que era por tradição, à época, a estância balnear que servia a Coimbra burguesa, restam igualmente memórias, sob um imenso areal que as obras portuárias estenderam até à imensidão, com a natural e progressiva desertificação da bonita e velha Praia da Claridade.

O espelho de água urbano reflete hoje, melhor do que nunca, a colina da velha Aeminium e a Torre da Universidade, com a mesma água Munda de outrora, que apenas as torrentes de inverno turvam temporariamente.

\section{As formas da história lidas pela arte}

"[...] Coimbra foi sempre terra de poetas e artistas, mestres da Arte para iniciados e devotos." [Correia, 1937]

Desde os tempos romanos que a cidade de Aeminium se ergue num nível superior ao do rio Mondego. Projeta-se numa sucessão de plataformas viradas para poente. Desse período resta o criptopórtico que serviu de base ao fórum. Alguns séculos mais tarde, a Sé-Velha é parcialmente escavada na encosta e projetada sobre a pendente. Estas plataformas ganham uma reciprocidade na margem oposta, com os mosteiros a introduzirem adicionalmente uma linearidade que sublinha a colina que acompanha o curso do Mondego. Da mesma forma, o casario de Coimbra desenvolve-se em anéis concêntricos em torno do Paço das Escolas.

É o diálogo entre estas plataformas, o fluxo do rio e as pontes visuais que medeiam as duas margens, que vai fixar a imagem de Coimbra durante vários séculos.

De súbito as pontes são cortadas. O Rio esconde-se da Baixa, bloqueada entre a colina e os grandes edifícios industriais, que romperam a escala da cidade medieval, proliferando sobre os muros ribeirinhos onde corre um pesado sistema ferroviário. Com esta ligação violada, as plataformas dos

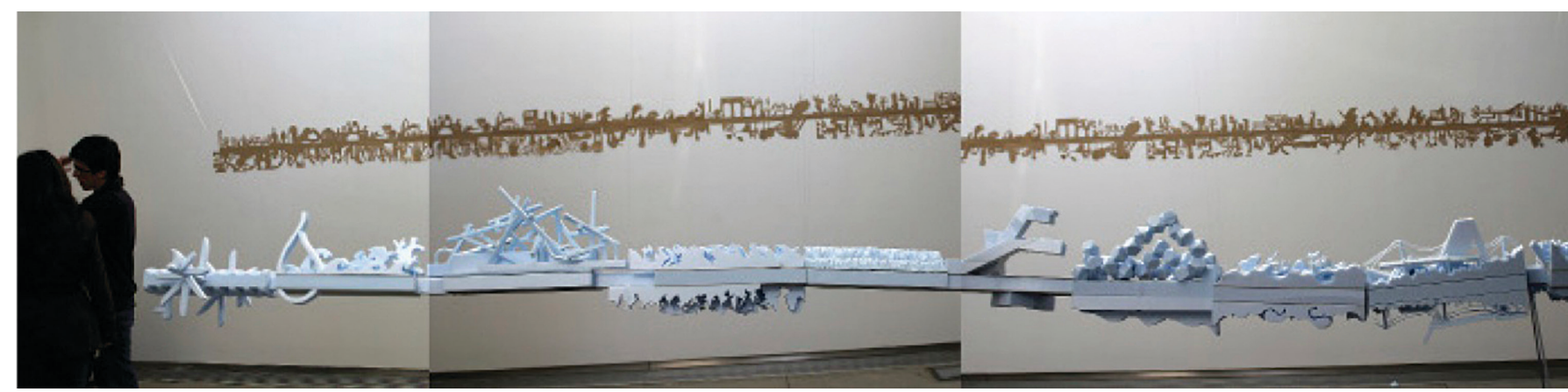


edifícios emblemáticos são ocultadas, e outras reaproveitadas para a instalação de fábricas, como o caso do Convento de S. Francisco, na margem poente. Embora o núcleo histórico da cidade se tenha mantido praticamente intacto, o crescimento circundante interrompeu esta relação direta entre Cidade e Rio, entre margem Este e Oeste.

Ambicionamos agora cumprir a tarefa árdua de "reconstrução de pontes", de retomar os patamares nas duas colinas, reestabelecer o fluxo do Rio. Esta é uma proposta de leitura da cidade como uma sucessão de patamares agrupados em volta de uma continuidade estrutural. Um jogo de ligações entre as margens. Têm surgido obras que apontam neste sentido, como o Centro de Congressos, em construção na velha ruína de S. Francisco. Também o Parque Verde do Mondego, que tem importância replicada: ao intervir nas duas margens aproxima-as, ligando-as física e visualmente; estendido, reforça o movimento linear do Rio; define um nível - tal como o Parque Manuel Braga havia feito em tempos anteriores; e atua como um palco para novas intervenções artísticas, como o Pavilhão de Portugal, testemunho da produção arquitetónica mais qualificada.

Sobre a velha Praça da Portagem, junto à Ponte de Santa Clara, o Memorial a Miguel Torga faz a síntese entre a pintura, escultura e literatura. Lançando-se sobre o Rio, relaciona-se com a ideia de "ponte visual" que, fisicamente amarrada, se solta e parte. É o mesmo conceito que encontramos na exposição "Rio Voador", que reúne a produção artística de vários autores, abraçando a ideia de um elemento natural ligado ao contexto, sendo ao mesmo tempo um ponto de partida para outras viagens.

\section{Imaginários culturais e artísticos I Poesia e fado de Coimbra}

O Mondego não é apenas o maior rio português. Tem uma dimensão mítica que o faz correr os cinco continentes onde a língua portuguesa é falada.

Nessa sua dimensão mítica, que impregna a cultura lusitana, o Mondego decidiu ser português. Nasce no centro do país, no ponto mais alto de Portugal continental. Precipita-se a grande velocidade em direção a Espanha, para, súbita e repentinamente, inverter o rumo e seguir para

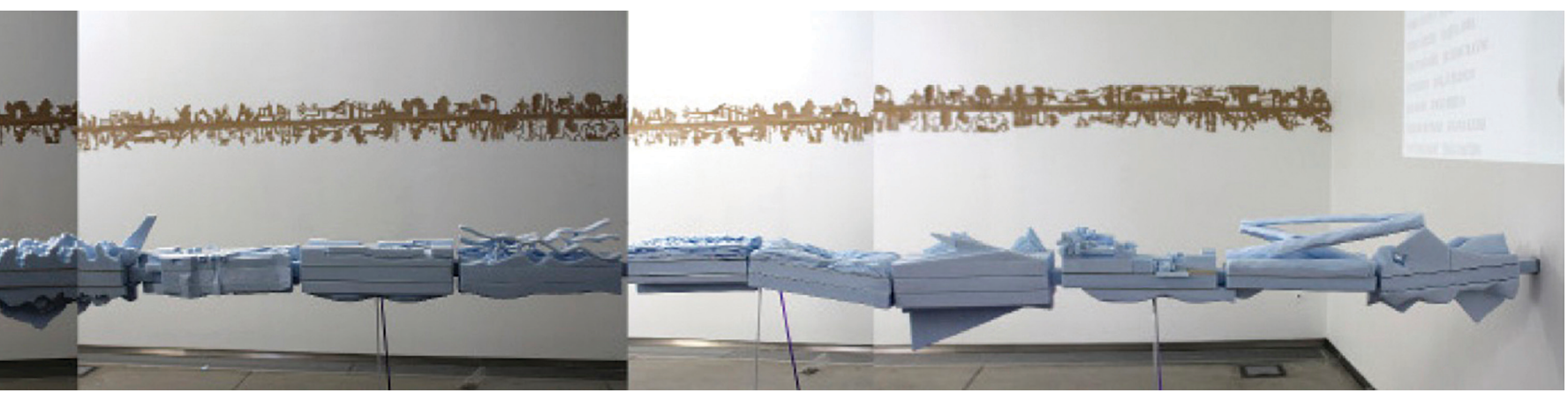


o Atlântico. Cruzando o país da fronteira ao mar, atravessa Coimbra, onde ganha uma alma que o torna muito maior que a sua dimensão física. Não sendo o maior dos rios que correm em Portugal, o Mondego é, de longe, o Rio mais cantado e romanceado por poetas, músicos e escritores portugueses. Isso deve-se ao facto de "a cidade do Mondego" ter sido, durante séculos, a única universidade de língua portuguesa, que formou elites que prestaram através de manifestações culturais diversas, em seu nome e dos espaços das suas margens, o tributo à cidade que as acolheu.

Na voz de Zeca Afonso, na guitarra de Carlos Paredes, nos versos de Camões, no olhar de Torga, o Mondego é a alma da língua portuguesa.
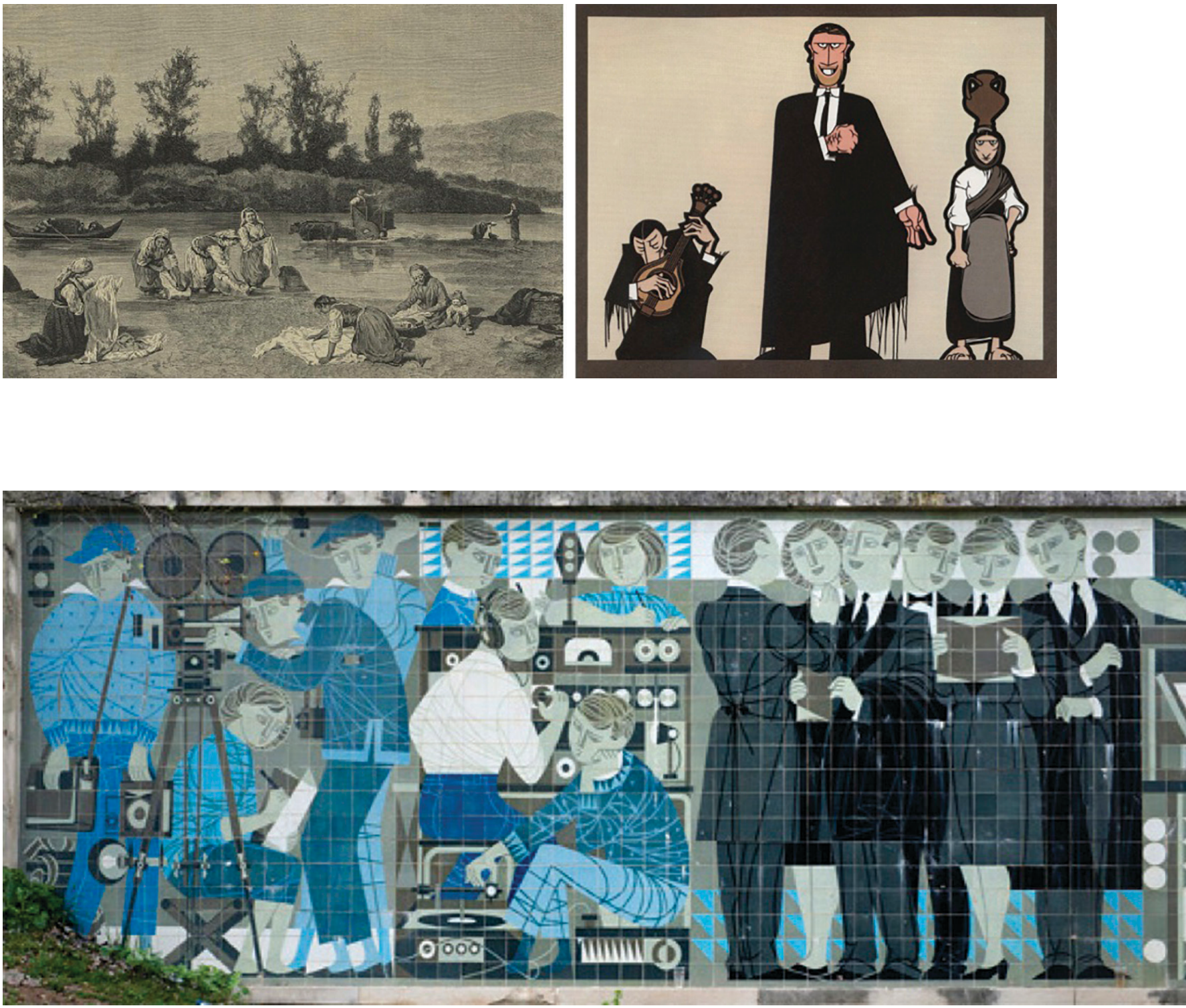
Doces águas e claras do Mondego,

doce repouso de minha lembrança,

onde a comprida e pérfida esperança

longo tempo após si me trouxe cego;

de vós me aparto; mas, porém, não nego

que inda a memória longa, que me alcança,

me não deixa de vós fazer mudança,

mas quanto mais me alongo, mais me achego.

Bem pudera Fortuna este instrumento

d'alma levar por terra nova e estranha,

oferecido ao mar remoto e vento;

mas alma, que de cá vos acompanha,

nas asas do ligeiro pensamento,

para vós, águas, voa, e em vós se banha.

Luís Vaz de Camões - Doces águas e claras do Mondego (1616)

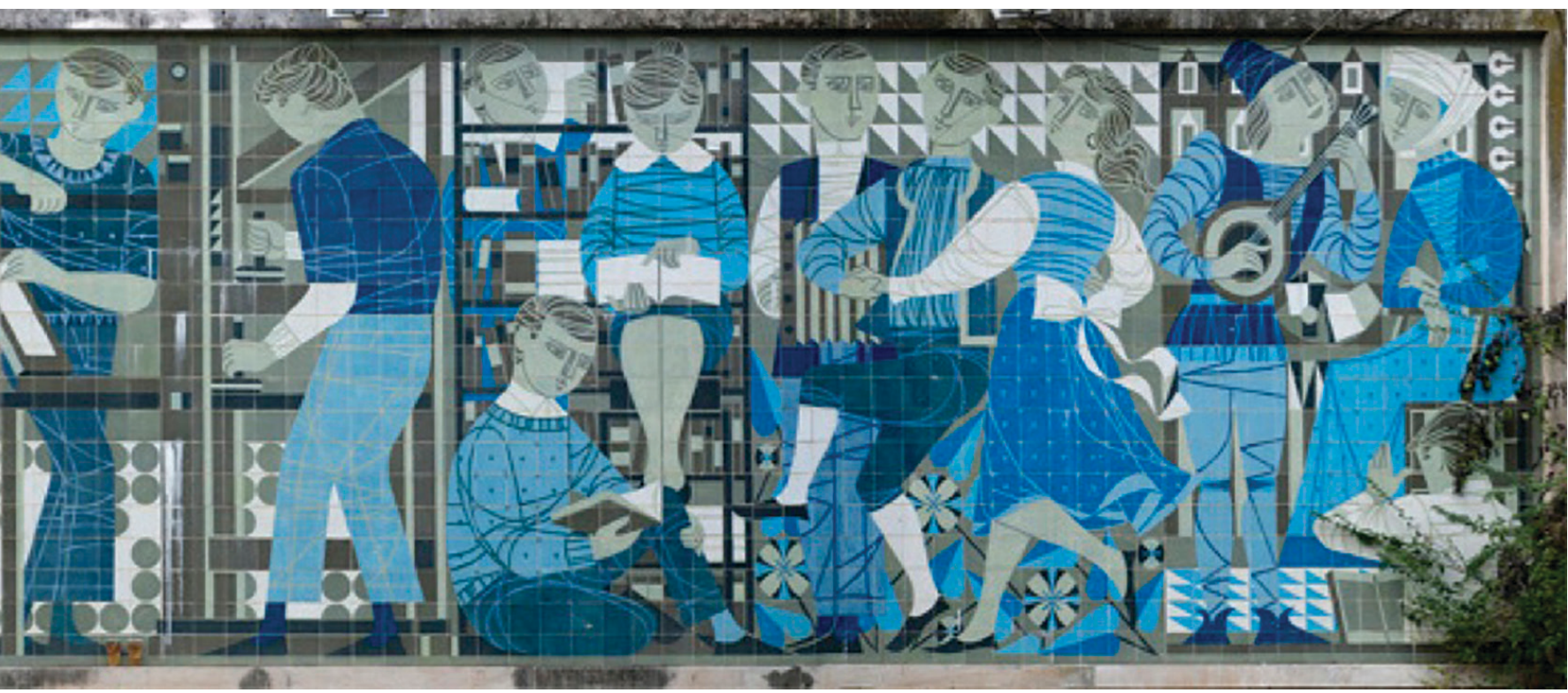




\section{Bibliografia}

Alarcão, Jorge de (2012), As Pontes de Coimbra que se afogaram no rio. Coimbra: Ordem dos Engenheiros.

Almeida, Elisa Manuela domingues (2006), Coimbra e o Rio Mondego, in EVolução do espaço físico de Coimbra (Catálogo DA EXPOSIÇÃO). COIMBRA: CMC.

Cabral, Estevão (1991), Memória sobre os danos do Mondego no Campo de Colmbra, e seu remédio, in Memórias EConómicas da Academia Real das Sciencias de Lisboa (1791). Lisboa: Banco de Portugal, tomo III, P. 141-165

Coelho, Maria Helena da Cruz (1983), o baixo Mondego nos finals da idade Média. Coimbra, fluC, 2 vols.

Correia, Vergílio (1937), Coimbra Cidade de Arte e Artistas. Humanidade. Coimbra.

David, Carlos; Rabadão, Célia; Pereira, Maria Filomena Santos; Simōes, Regina (1986), o porto da Figueira da Foz. Ontem, Hoje, Amanhã. Figueira da Foz: Biblioteca Municipal.

Fortes, Mário (1929), o Aproveitamento Geral da Bacia do RIo MondêGo, pelo sistema Confederativo sindical hidrografico. COIMBRA: Portugália.

Jorge, Filipe; Bandeirinha, José António (2003), Coimbra vista do céu. Lisboa, Argumentum.

lencastre, Armando (2004), Hidráulica Fluvial e Agricola - Memórias Técnicas. lisboa: lNeC, vol.III.

Loureiro, Adolfo (1874), Memoria sobre o Mondego e barra da Figueira. Revista de Obras públicas e Minas, ano V, TOMO V.

Loureiro, Adolfo (1905), Porto da Figueira da Foz. lisboa: Imprensa Nacional.

Martins, Afonso Nuno (2011), Projeto territorial do Parque Patrimonial do Mondego - revisitações da paisagem RIBEIRINHA. LISBOA: FAUTL (DISSERTAÇÃO DE MESTRADO).

Martins, Alfredo Fernandes (1940), O esforço do homem na bacia do Mondego. Coimbra: FluC (tese de licenciatura).

Nunes, Mário (1990), Colmbra, imagens do passado 1940-1969. Coimbra: Minerva.

Quintela, António de Carvalho (1986), O Mondego na hidráulica fluvial portuguesa até ao século XX, in História E Desenvolvimento da CiênCia em Portugal. Lisboa: Academia das Cienncias de Lisboa, II Vol., p. 1025-1040.

Quintela, António de Carvalho (2006), A utilização e o domínIo da ÁGua na baCia hidrográfica do Mondego: Problemas E SOLUÇÕES AO LONGO DO TEMPO. LISBOA: CEHIDRO / INSTITUTO SUPERIOR TÉCNICO.

Sanchez, Rui (1996), O problema secular do Mondego e a sua resolução. Lisboa: LNEC.

Vandelli, Domingos (1991), Memória sobre o encanamento do Rio Mondego, in Memórias Económicas da Academia Real das Sciencias de lisboa (1791). Lisboa: Banco de Portugal, tomo III, p.13-19.

Veloso, A. Santos (1989), A génese do PidR do Baixo Mondego. Sociedade e Território - Revista de estudos urbanos E REGIONAIS, N9, PORTO, P.74-82. 


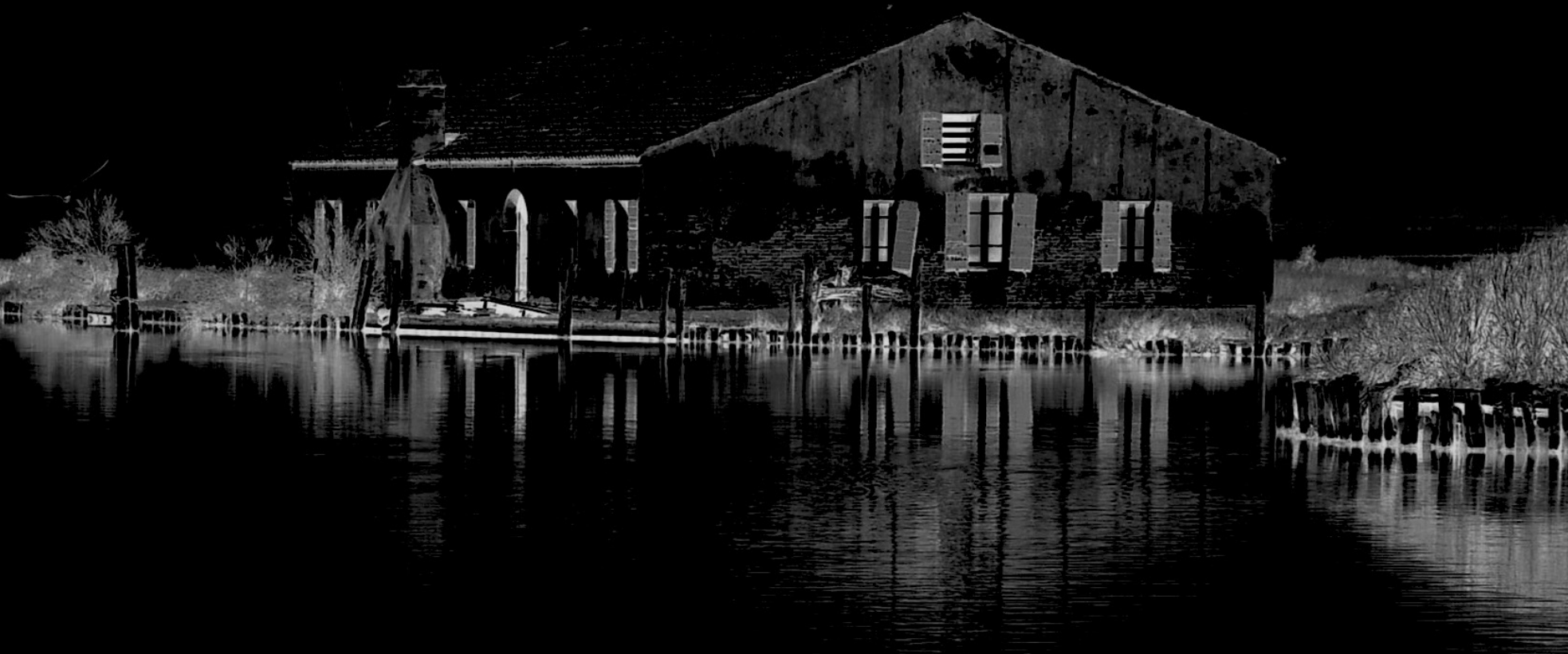

\section{COMACCHIO}

\section{LEITURA DE UM TERRITÓRIO}

ROMEO FARINELLA (Coordenador)

LUCILLA PREVIATI MICHELE RONCONI ELENA DORATO ALICE CLEMENTI ANNA LUCIANI JUSTINA SOLTYSIUK 


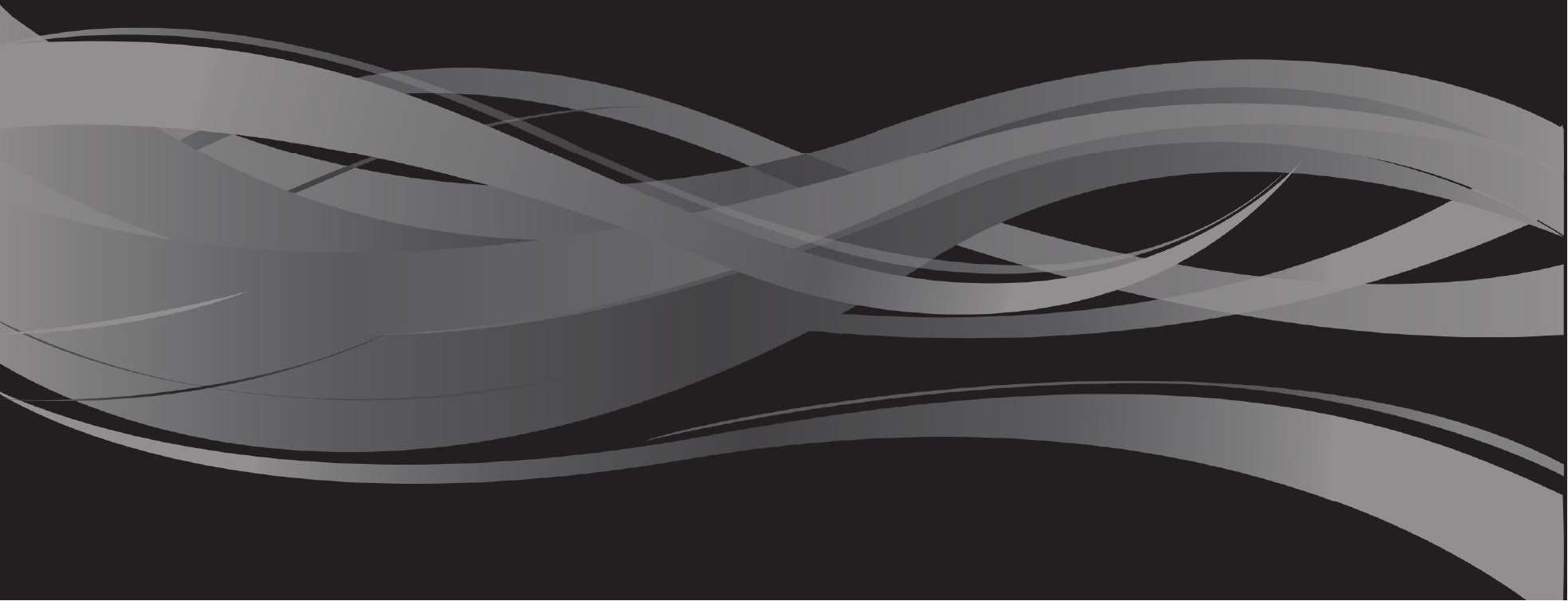




\section{A CONSTRUÇÃO DE UM TERRITÓRIO}

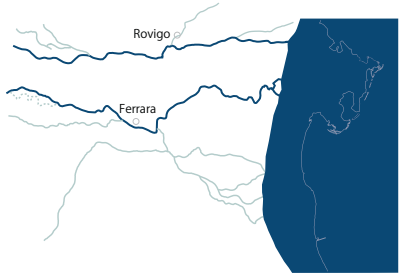

Idade do Bronze

Séc. XIV
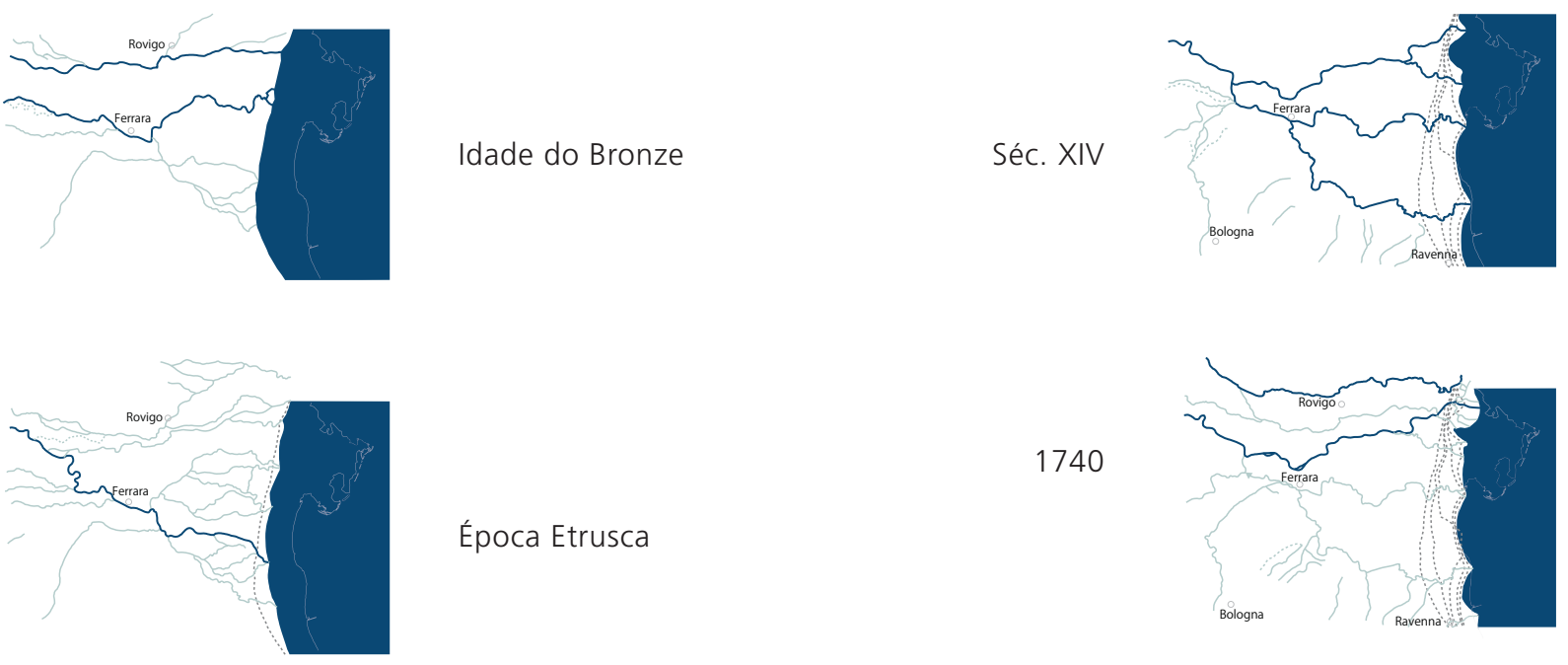

1740
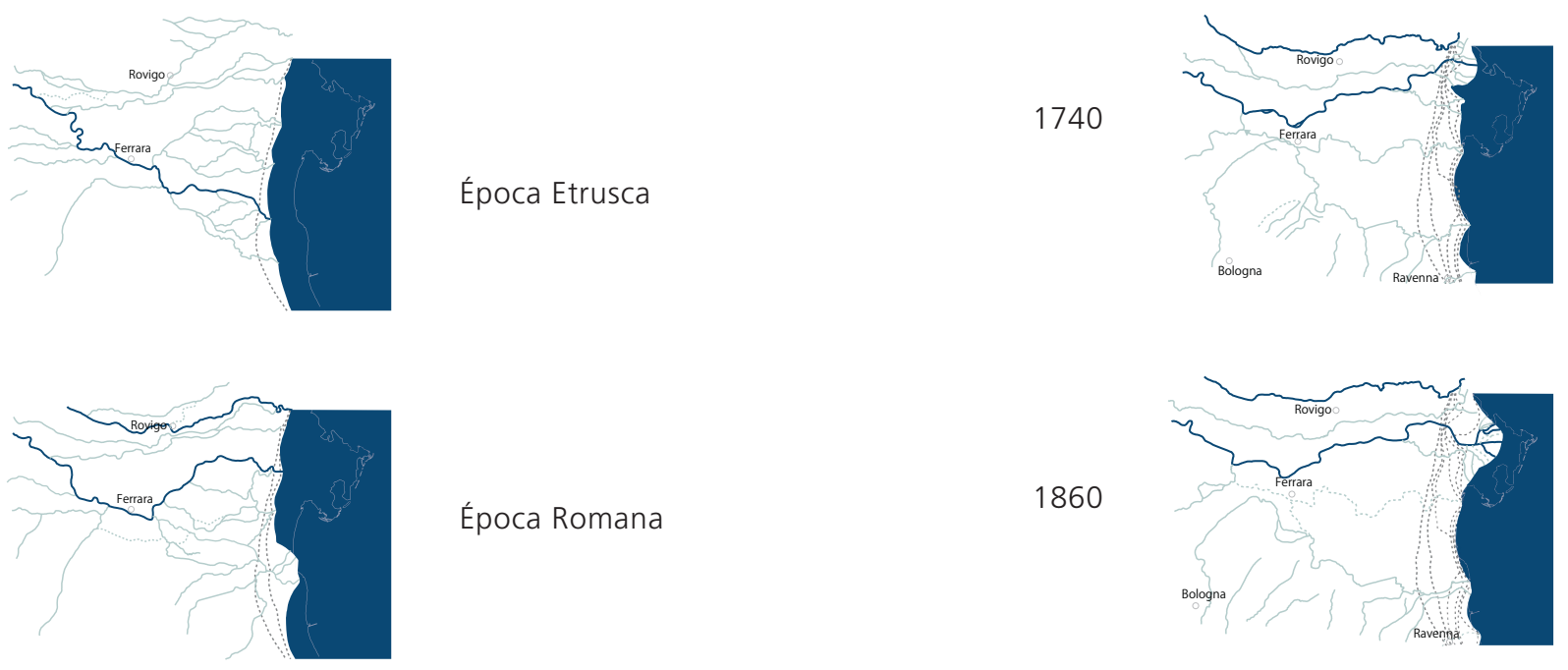

Época Romana
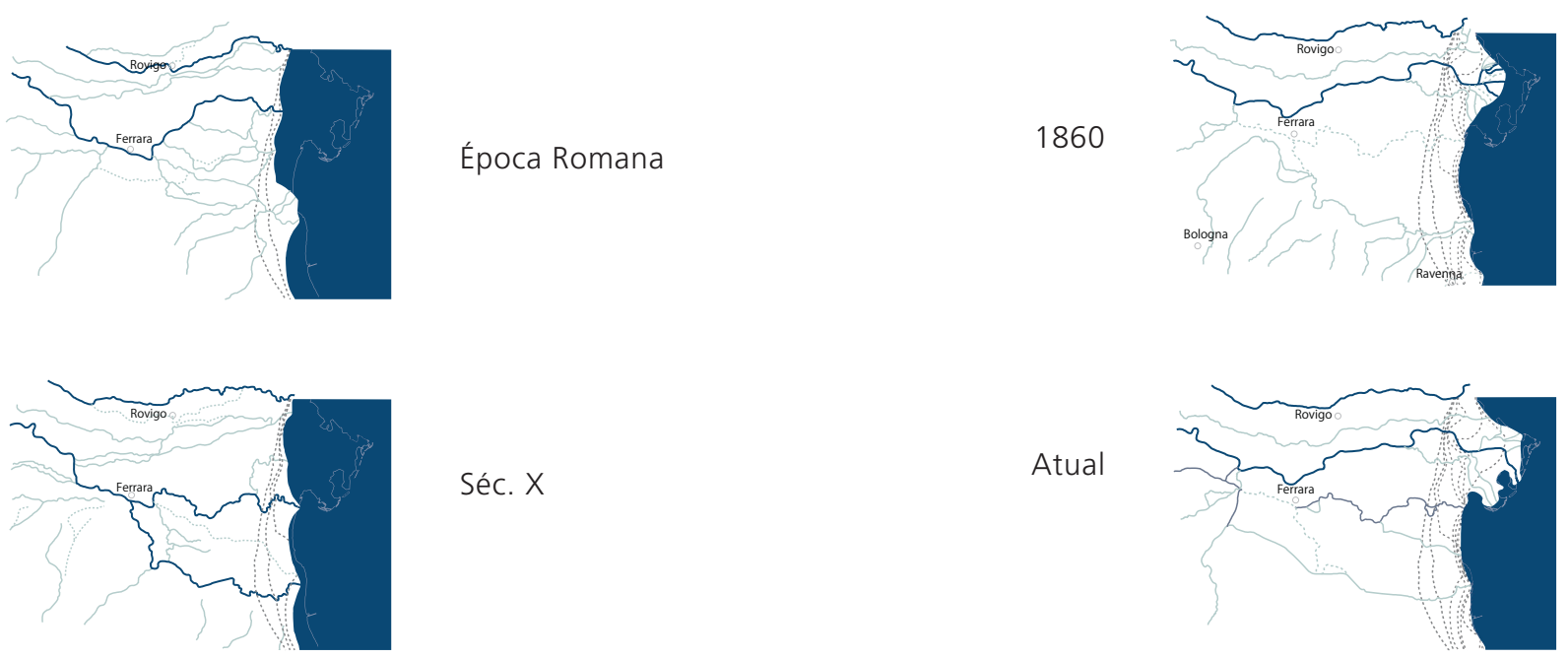

Séc. X

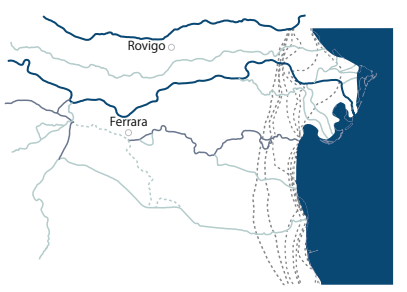

\section{Atualmente}

O território deste projeto tem a peculiaridade de ser uma junção de natureza e de intervenção humana, a qual se revelou imprescindível ao longo dos séculos, permitindo a aglomeração humana em terras continuamente oscilantes entre terra e água. Os efeitos resultantes dos eventos hidrográficos representam, de facto, a fundação do atual ordenamento territorial, tratando-se de um contexto cuja configuração presente, a nível de aglomeração e de ampla extensão geomorfológica, remonta a apenas dois séculos atrás. Um destino intimamente ligado às águas devido à posição em que se situa o território de Ferrara, no extremo oriental da planície do Pó, onde esta termina no mar Adriático: situação que tornou o território uma zona de colheitas e uma saída para o mar de 
um conjunto de rios do interior. O que tornou ainda mais complexa a situação hidrográfica local foi a enxertia, com uma direção substancialmente perpendicular em relação às directrizes fluviais da planície interna (orientadas na direcção oeste-este em conformidade com a altimetria do Pó), dos cursos de água apeninos provenientes do sul e espalhando-se, ao longo dos séculos, nos vales da baixa Emilia-Romagna. Além destas condições, existe também a altimetria específica destes territórios, completamente planos e em grande parte abaixo do nível do mar e, assim, sujeitos ao longo do tempo a repetidos e significativos fenómenos de abaixamento vertical, devido à presença de depósitos comprimíveis, fruto das águas que chegam e da extração indiscriminada de água e metano do subsolo, ocorrida no segundo pós-guerra.
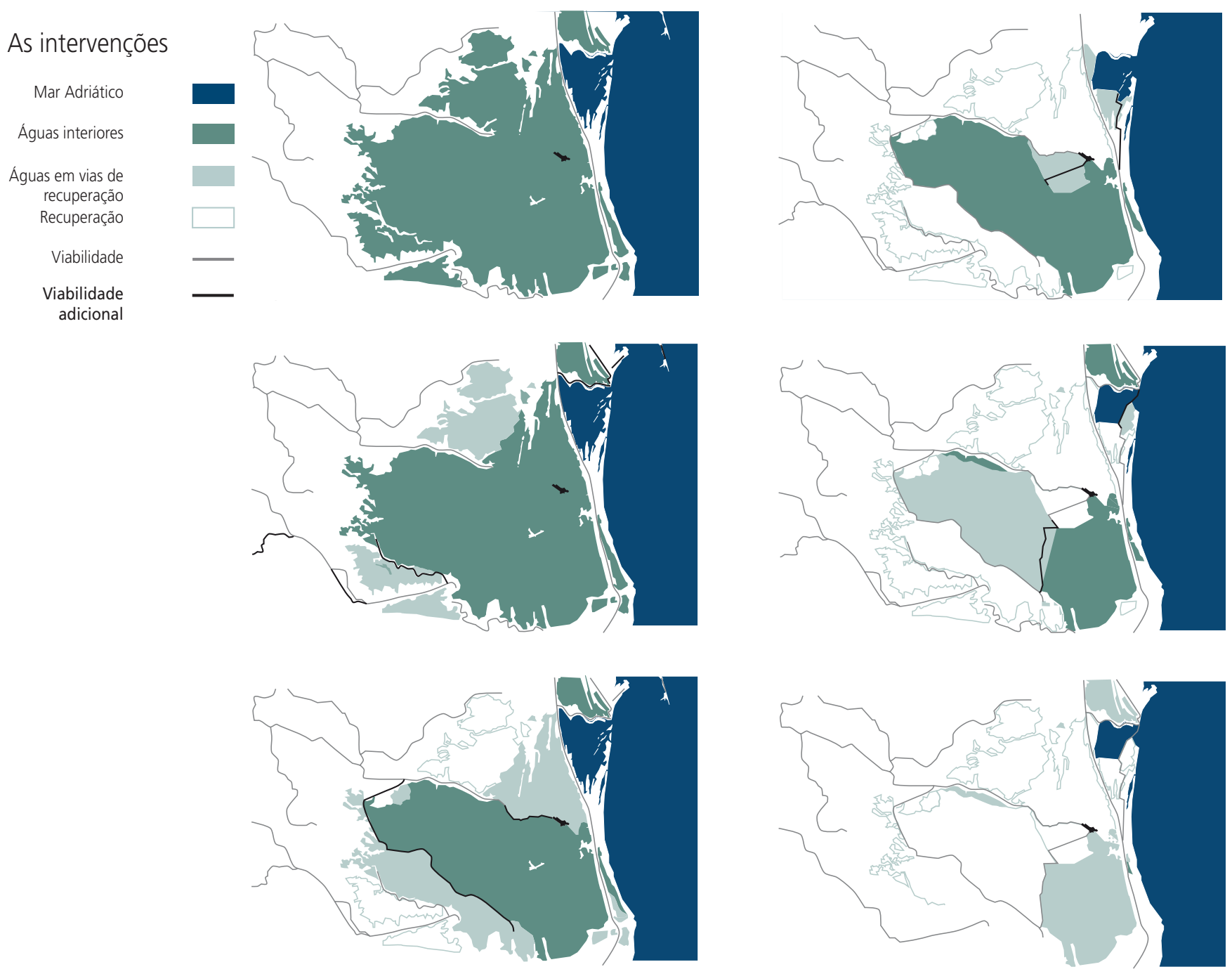


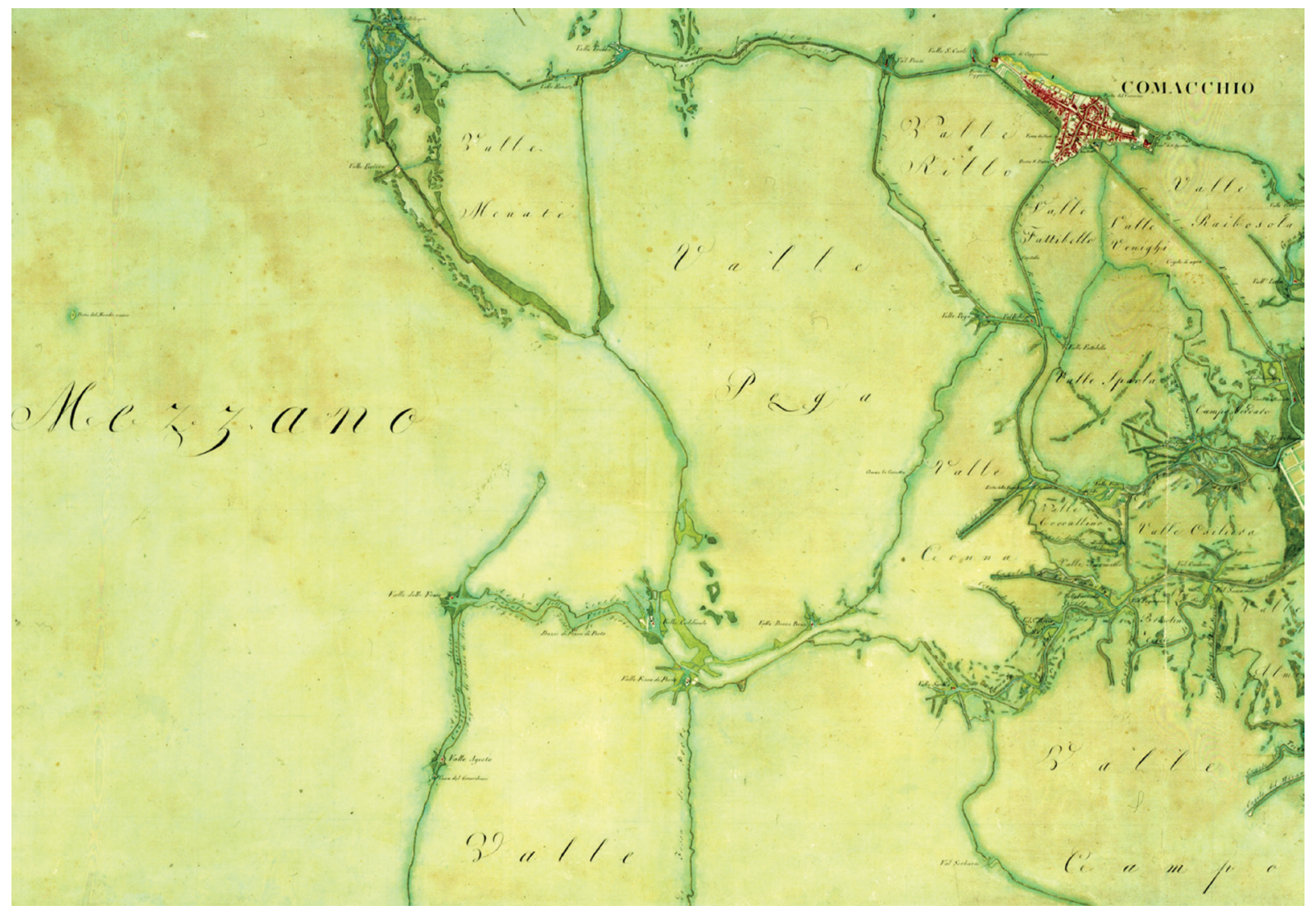

Extrato do Mapa do baixo Pó, 1812-14, Vienna, Kriegsarchiv, B VII a 284-286

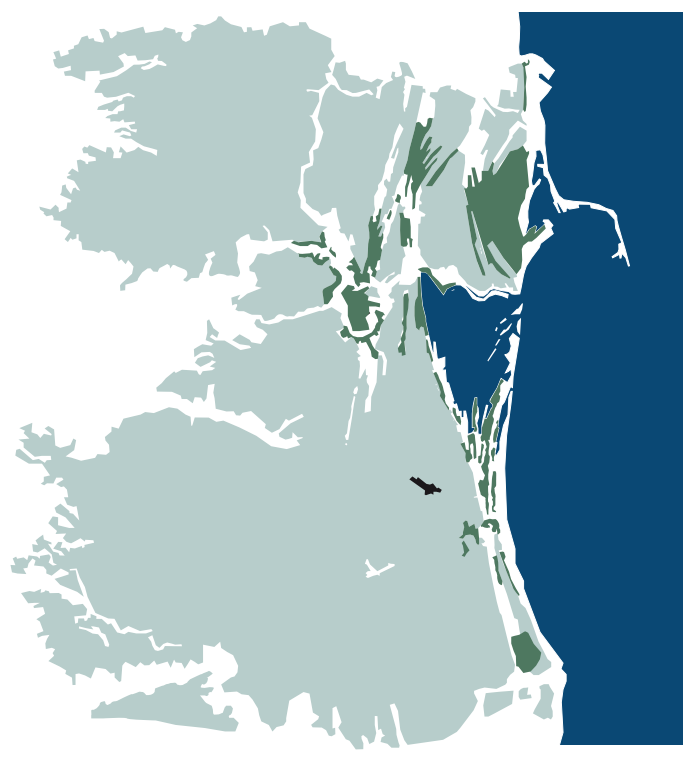

1814 - Estrutura da área arborizada

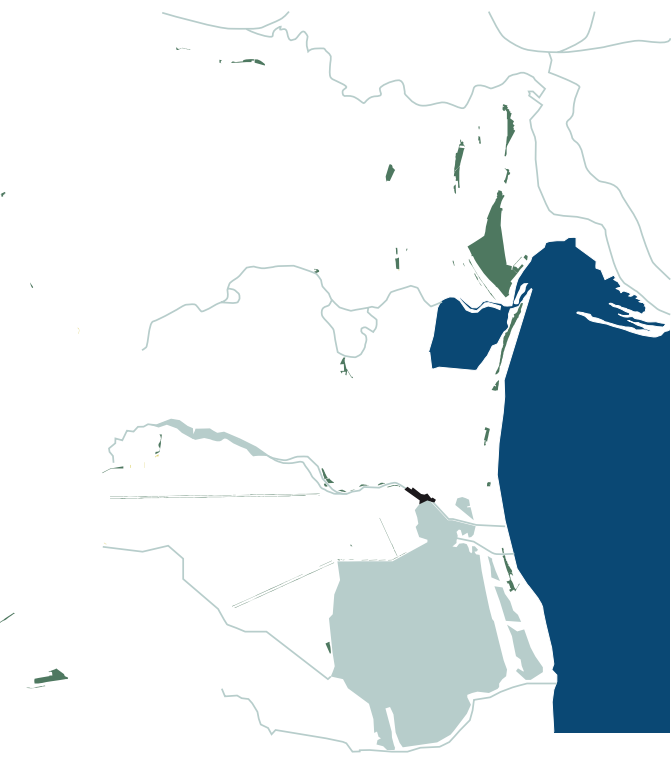

2012 - Área arborizada atual 
Nós existentes

Nós existentes

Passadiços em pedra sobre a àgua

Nós do projeto

Corredores do projeto

Corredores existentes

Linhas de árvores

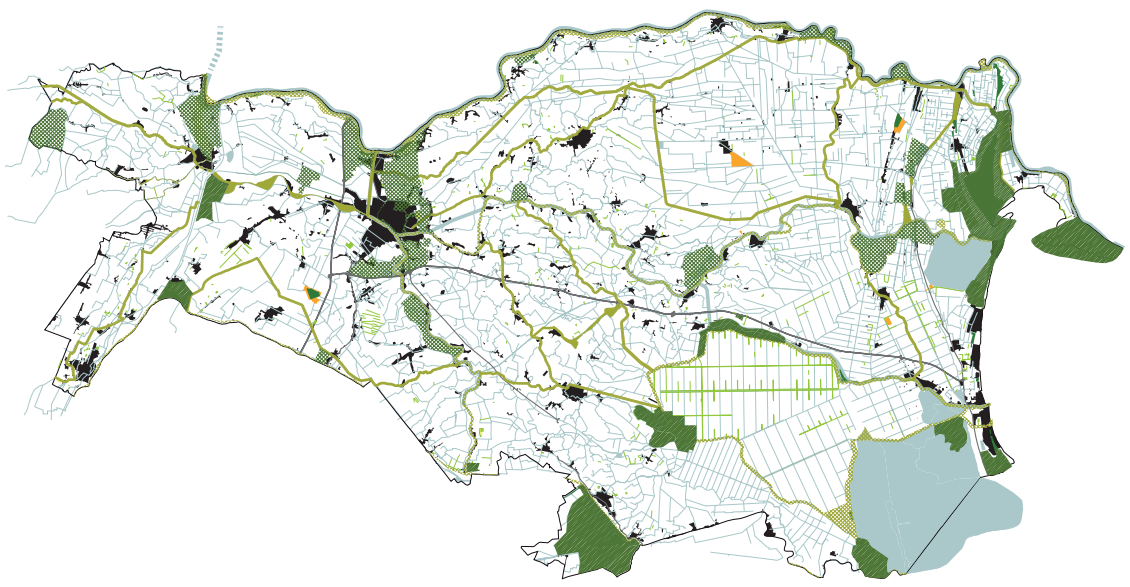

Tudo isto permitiu que o mar invadisse algumas destas zonas litorais anteriormente secas. Este conjunto de condições, associado à inevitável oscilação das diferentes condições climatéricas, e as estratégias do governo local provocaram uma sucessão de eventos que mudaram profundamente, de forma relativamente rápida, o território de Ferrara. Dada a multiplicidade dos fenómenos, muitas vezes contemporâneos e inter-relacionados, criou-se uma rede hidrográfica local extremamente complexa, que soube utilizar (e modificar) vias de água existentes, ligando-as a estruturas artificiais, enquadradas num projeto de território de grande dimensão.

O atual ordenamento físico é, de facto, fruto das respostas que o homem soube encontrar, ao longo dos tempos, para responder a uma série de problemáticas ligadas à rede hidrográfica, à subsidência natural e artificial, ao aumento do nível das águas do mar e à diminuição da sedimentação, devido ao aumento das escavações nos rios. Estas especificidades são hoje salvaguardadas por uma série de vínculos e tutelas, entre as quais a instituição, iniciada em 1988 com a Lei Regional, do Parque do Delta do Pó, e a inserção, em 1999, pela Unesco, na lista de Bens do Património Mundial. Como acontece quando a água está entre os elementos configuradores da morfologia de um território, a mutabilidade dos lugares sempre foi um traço saliente de Ferrara; contudo, é surpreendente a rapidez com que o território se modificou, se compararmos com outros contextos em que o ordenamento geomorfológico está traçado desde há muito tempo.

Ferrara sempre se caracterizou por ter um ambiente "brando", facilmente alterável por eventos naturais e artificiais: um território que se poderia definir de "argila", por essa capacidade de mudar de forma, devido a forças externas, mas também capaz de conservar os sinais do tempo; esta maleabilidade condiciona, de facto, a "memória", pronta a acolher novos eventos, mas rápida a esquecer. Trata-se de traços muitas vezes passageiros, não incritos à força, precisamente devido à extrema volubilidade destas terras, que podem ser apagadas por eventos sucessivos ou contrários, com a mesma facilidade com que surgiram. 
Muitas paisagens do passado são hoje vestígios, pedaços ou espécies disseminadas em contextos estranhos, cujo sentido permanece incompreensível para quem não tem os conhecimentos adequados para as interpretar: entre estas, estão numerosos elementos de valor ambiental e naturalístico, resquícios de uma progressiva artificialização do território, possível graças aos sucessivos trabalhos de recuperação. Em Ferrara, se por um lado a saída das águas permitiu o alargamento do território oriental e a infra-estruturação e aproveitamento para fins agrícolas, por outro apagou quase por completo uma paisagem de terras e águas única em Itália.

O núcleo central de Comacchio apresenta um ordenamento topográfico específico, de forma alongada, que faz lembrar o casco de uma embarcação: esta característica confere um ambiente particular à zona em que se encontra a cidade, fundada sobre algumas ilhas, treze segundo a tradição, separadas por canais estreitos e circundadas pelas águas baixas das lagoas costeiras.

Ao longo do tempo, a morfologia do tecido urbano modificou-se, originando, ainda que com as devidas especificidades do território, os mecanismos de evolução de outras realidades urbanas. Depois de uma expansão inicial, na sequência de prováveis trabalhos para o reforço das margens, as ilhas foram subdivididas devido à escavação de canais artificiais, numa espécie de "loteamento" das áreas emersas.

Apenas no decurso do século XX, após a construção das ligações rodoviárias entre a cidade e o território, ao que se acrescentaram os efeitos da reabilitação, tornando cada vez mais Comacchio numa cidade de terra firme, o número de canais reduziu-se devido à terraplenagem e os canais converteram-se em vias rodoviárias, o que implicou a demolição de várias pontes.

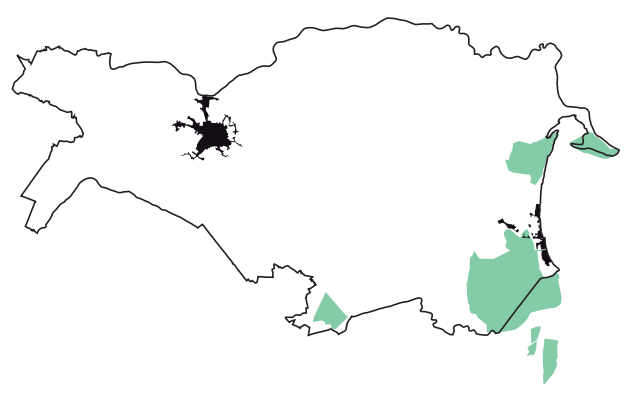

Zonas húmidas Ramsar

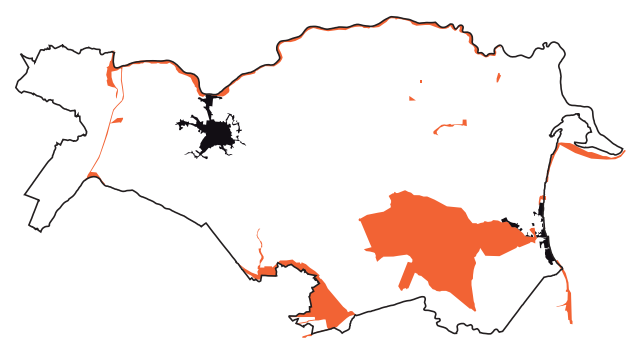

Locais de importância comunitária e Zonas especiais de proteção

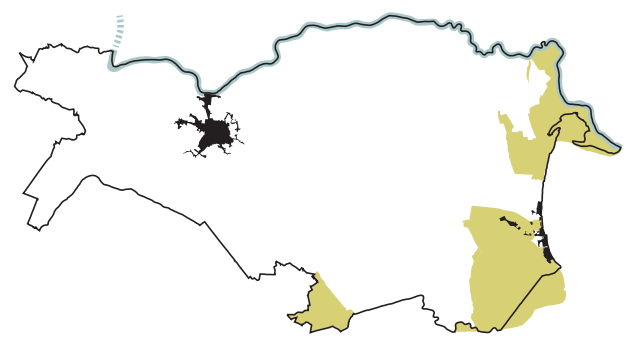

Parque do Delta do Pó 
Evolução do sistema urbano Comacchio-Costa

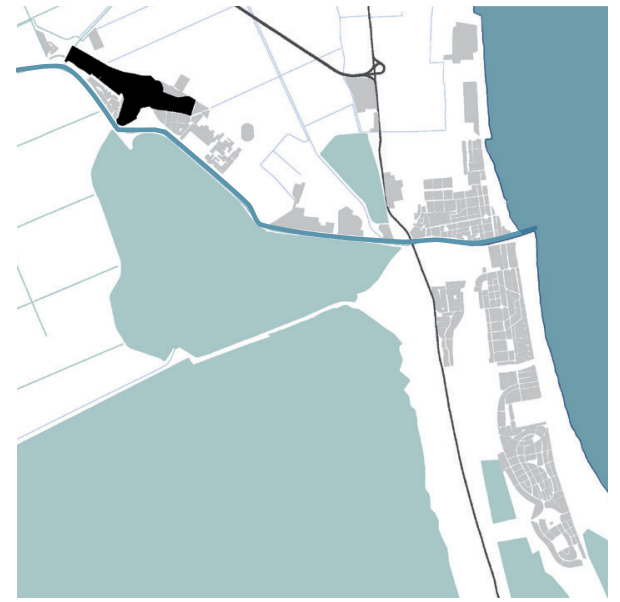

Anos 1940 - A Comacchio histórica

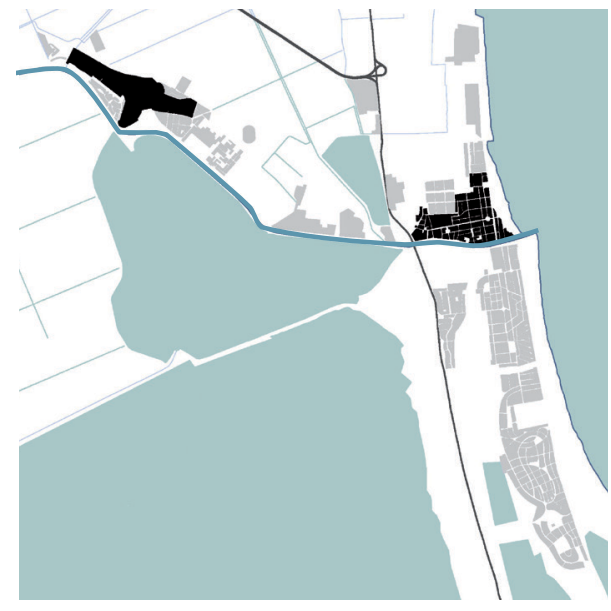

Anos 1950 - Reconstrução do Porto Garibaldi

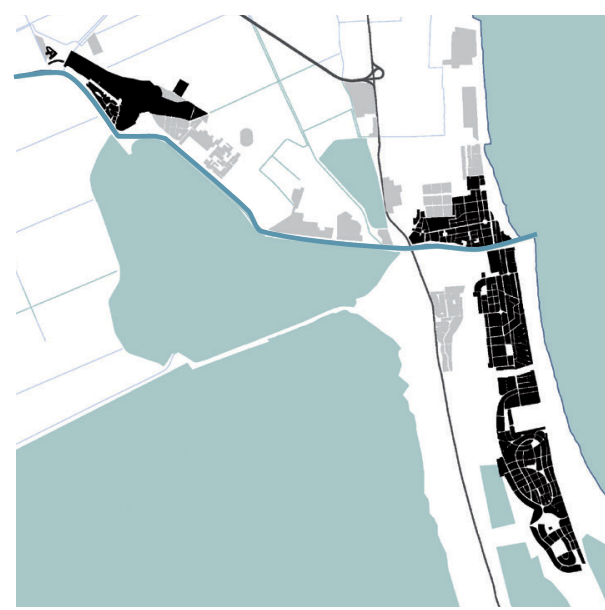

Anos 1960 - Construção da Costa Este e de Spina

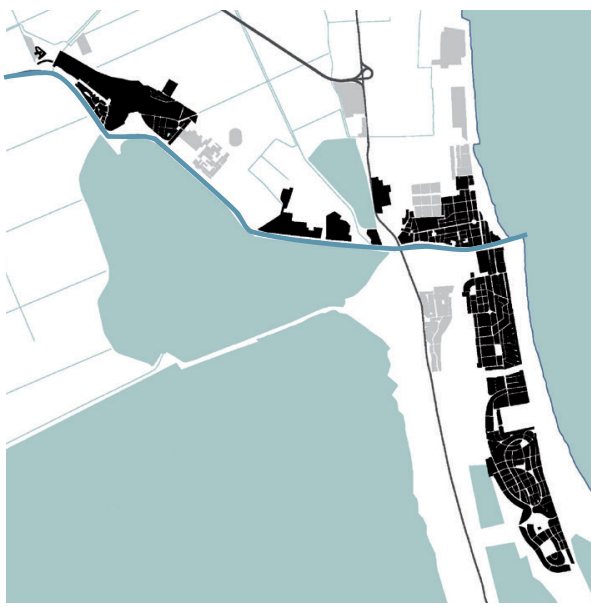

Anos 1970 - Primeiras implantações industriais

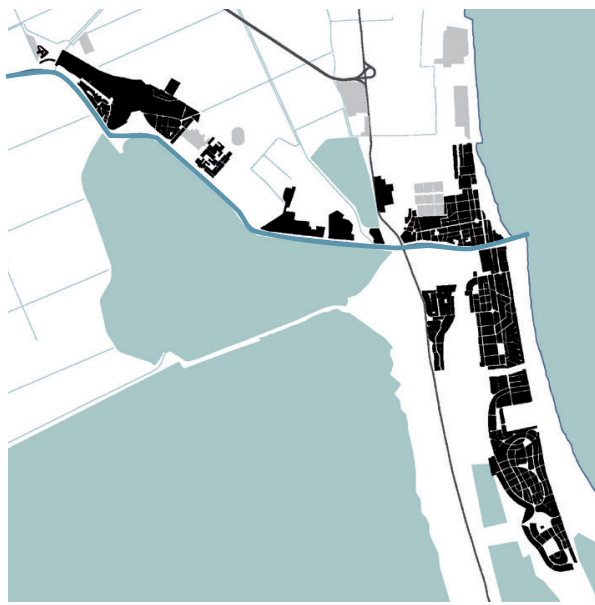

Anos 1980 - Construção dos quarteirões ERP

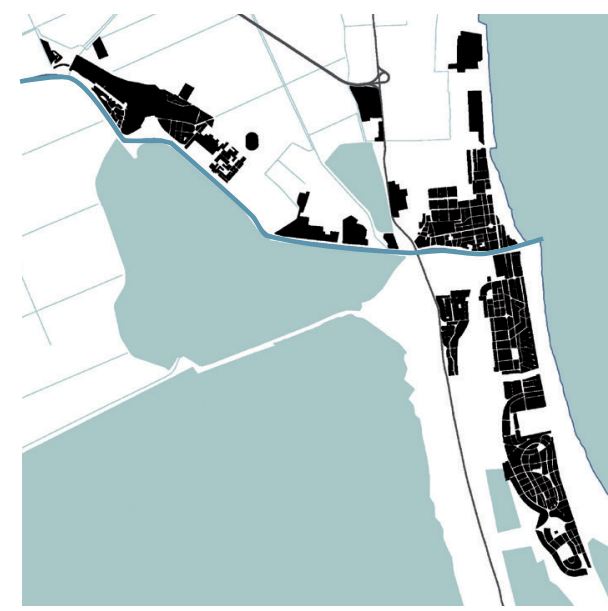

Anos 1990 - Nascimento da cidade do comércio 
A via Romea é uma barreira física entre o sistema costeiro e o interior, caracterizada pela ausência de travessias seguras e, portanto, por um elevado grau de perigo. Os elevados números de tráfego incrementam a sua natureza de elemento de rotura no território de comacchio.

Inverno: despovoamento da costa. As atividades urbanas distribuem-se principalmente entre Comacchio, Porto Garibaldi e Lido degli Estensi.

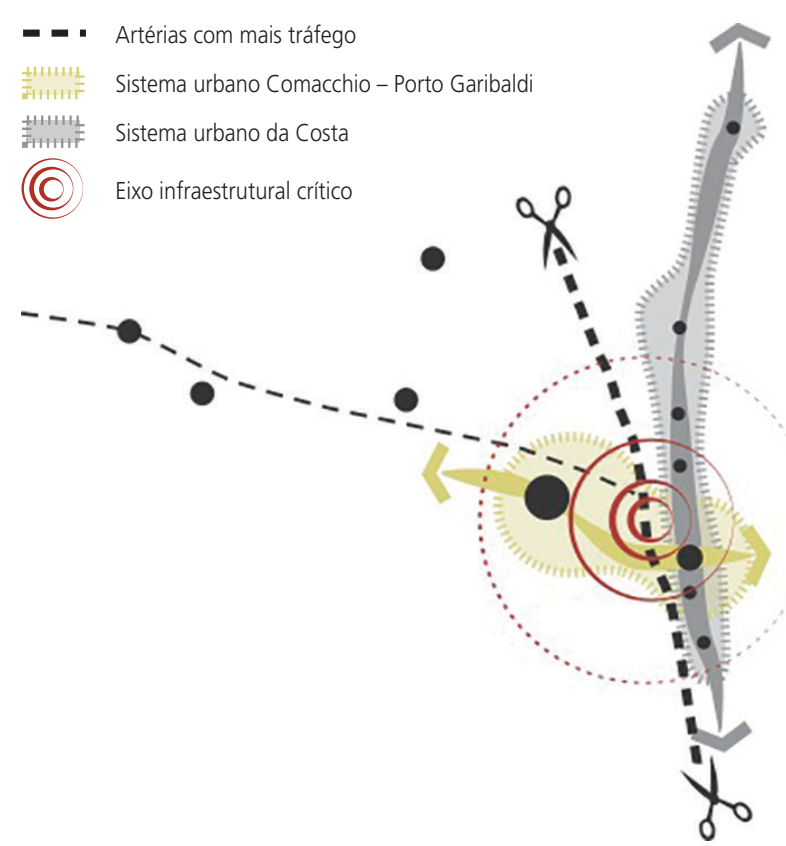

Verão: Repovoamento das praias e o consequente congestionamento de toda a faixa costeira.
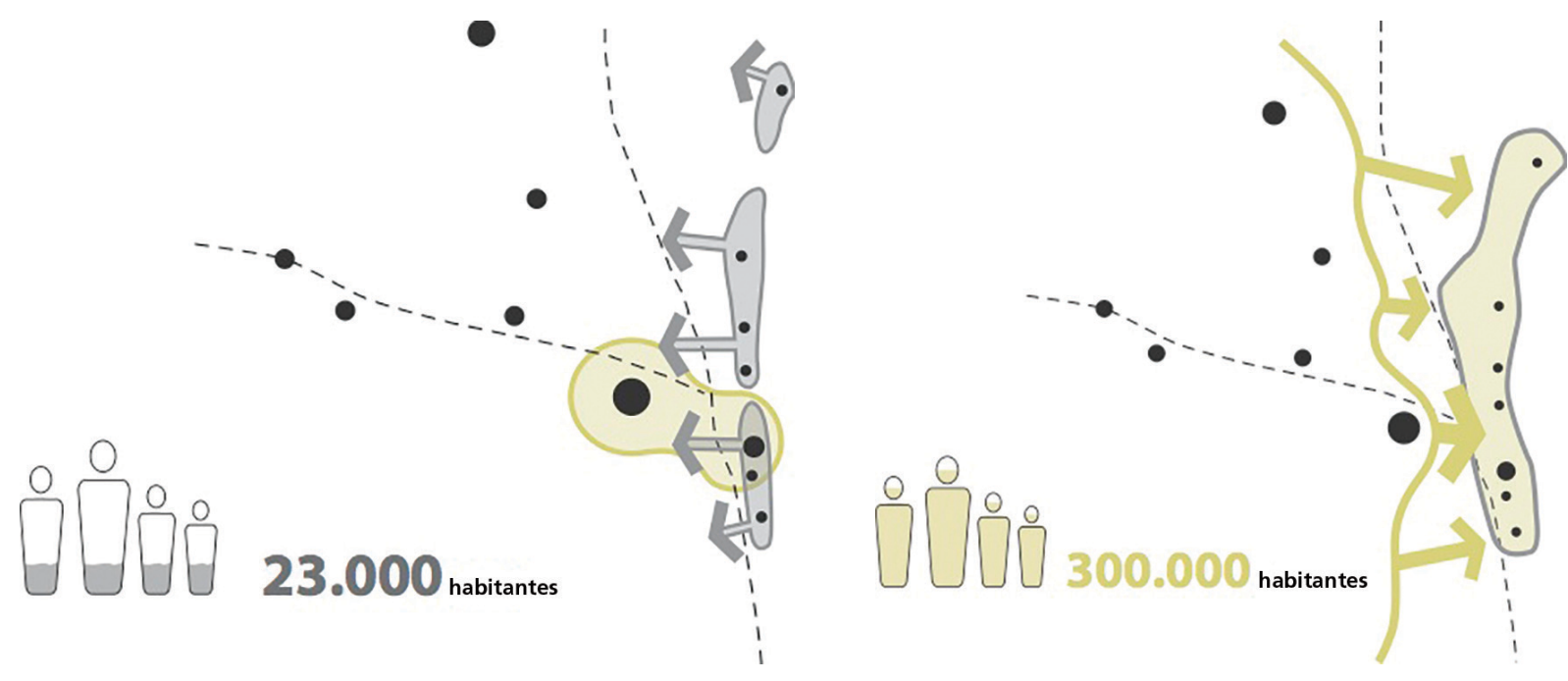


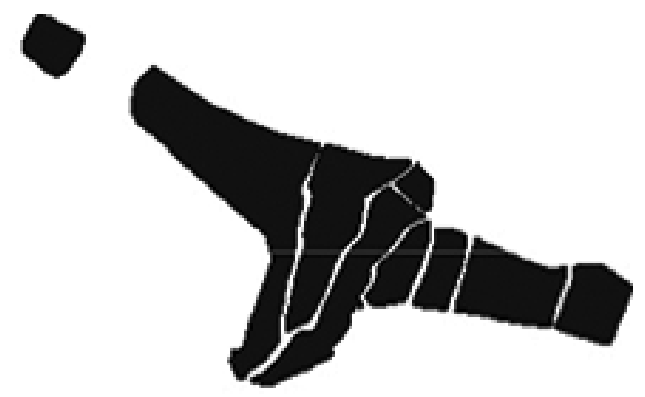

Núcleo primitivo de ilhas no interior do vale

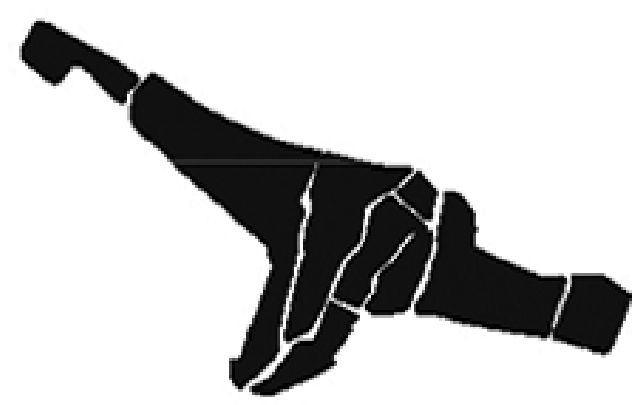

Ampliação das ilhas e criação de ligações entre os canais internos

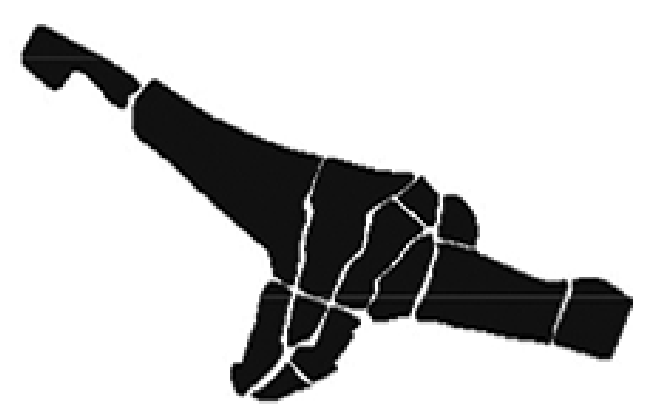

Fracionamento transversal

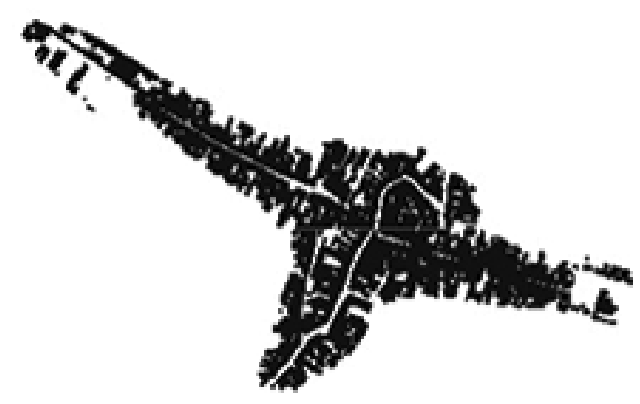

Configuração atual

\section{A evolução de uma cidade lagunar}

A cidade desenvolve-se, quase essencialmente, a partir de dois aspetos principais: o primeiro que parte da via Mazzini até à via Garibaldi, agora em estrada, mas no passado certamente um curso de água, direcionado de noroeste para sudeste; o segundo, perpendicular ao primeiro, formado por estábulos e canais centrais, desde a Via San Pietro à via Cavour, encontrando o primeiro precisamente no centro da cidade, a qual permanece dividida em quatro setores, num lugar marcado pelo perfil da Torre do Relógio. A aglomeração urbana desenvolve-se em redor destes dois percursos, fechado pelo canal perimetral e marcado, nas margens do eixo maior, por dois monumentos, ambos religiosos: a noroeste o complexo de Santa Maria em Aula Regia, com o conexo Portico del Cappucini e a sudeste o antigo Convento de Sant'Agostino, hoje à espera de uma desejada renovação.

\section{O património monumental}

O traço urbanístico mais característico de Comacchio foi-se formando após a devolução do ducado Estense ao Vaticano. Foi nesta época, entre os séculos XVII e $X V I I I$, que se ergueram os mais importantes exemplos de construção especializada e monumental que marcam, ainda hoje, o núcleo central da cidade: a Loggia del Grano, edificada na primeira metade do século XVII, a pequena Ponte delle Carceri, provavelmente construída entre 1631 e 1635, a mais famosa Trepponti, erguida em 1638, com projeto do arquitecto camarário Luca Danese, a Cattedrale, dedicada a San Cassiano e terminada em 1705, o Ospedale di San Camillo, finalizado em 1786. Há outras construções históricas que servem de coroa da cidade: o edifício de Pescherie Vecchie, o Palazzo Bellini, que acolhe atualmente a Biblioteca Civica, o Museo del Carico della Nave romana, emerso pela Valle Ponti. 


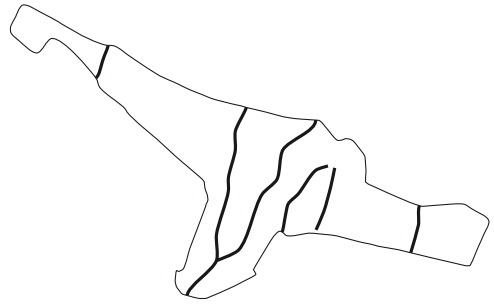

Primeiros canais paralelos

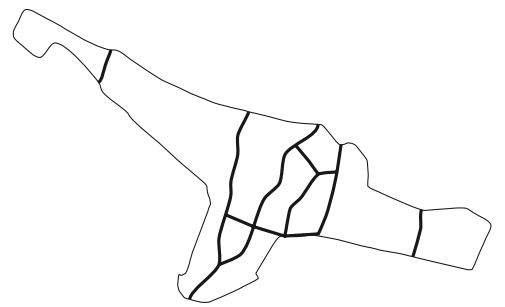

Época tardo-Romana/Medieval - as primeiras ligações

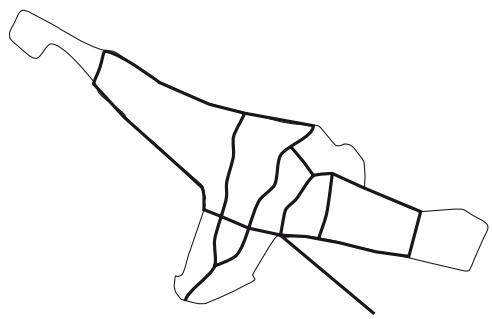

Época Renascimento/Barroco - arranjo dos canais perimetrais e criação do Canal Pallotta

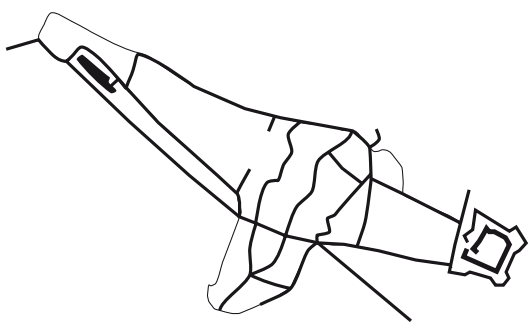

Séculos XVI/XVII - conclusão dos canais perimetrais e criação do canal artificial externo, Canal Grande da Francescona

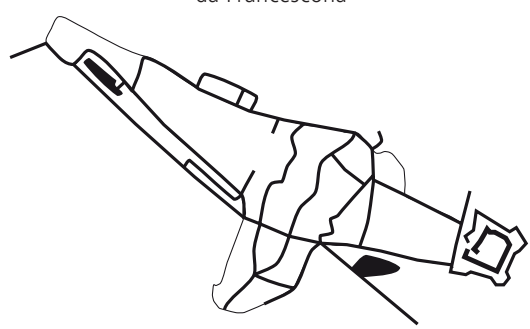

1817 - reforço de uma rede hídrica anteriormente desenvolvida no âmbito de pequenas intervenções no tecido urbano

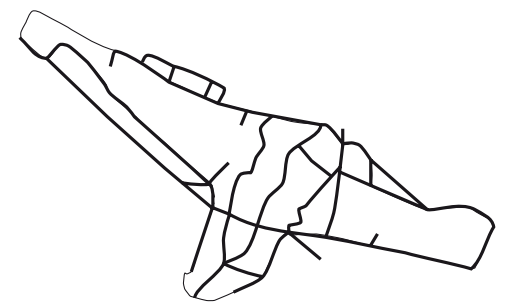

1860 - eliminação do fosso perto da Fortaleza Austríaca, o antigo Mosteiro dos Padres Agostinianos Descalços

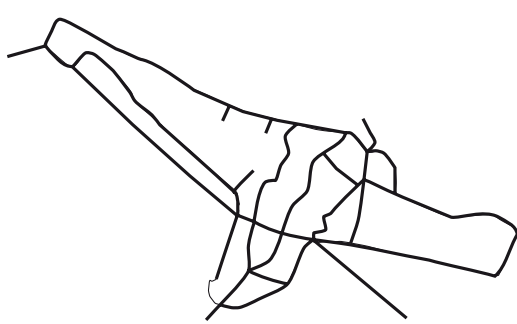

1940 - conclusão dos canais perimetrais

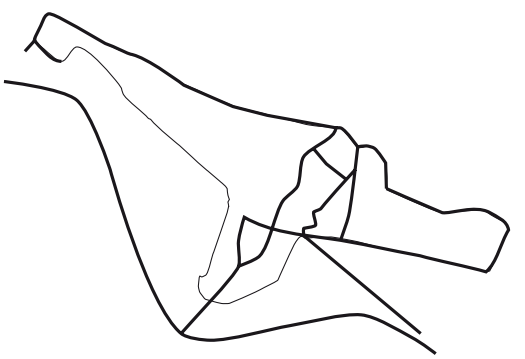

1974 - Redução da rede hídrica de superfície e criação de um canal navegável ligado aos vales
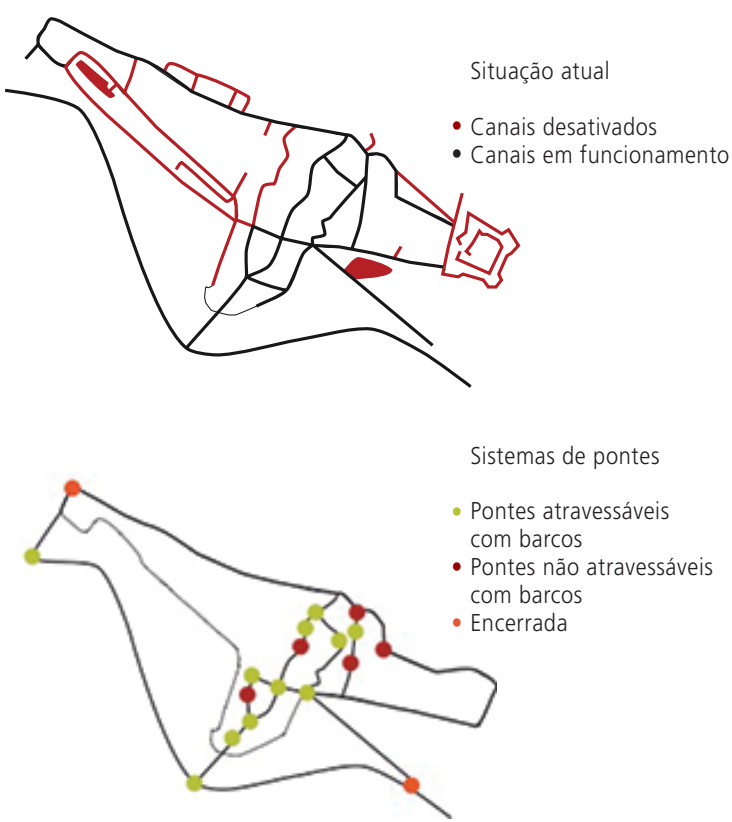


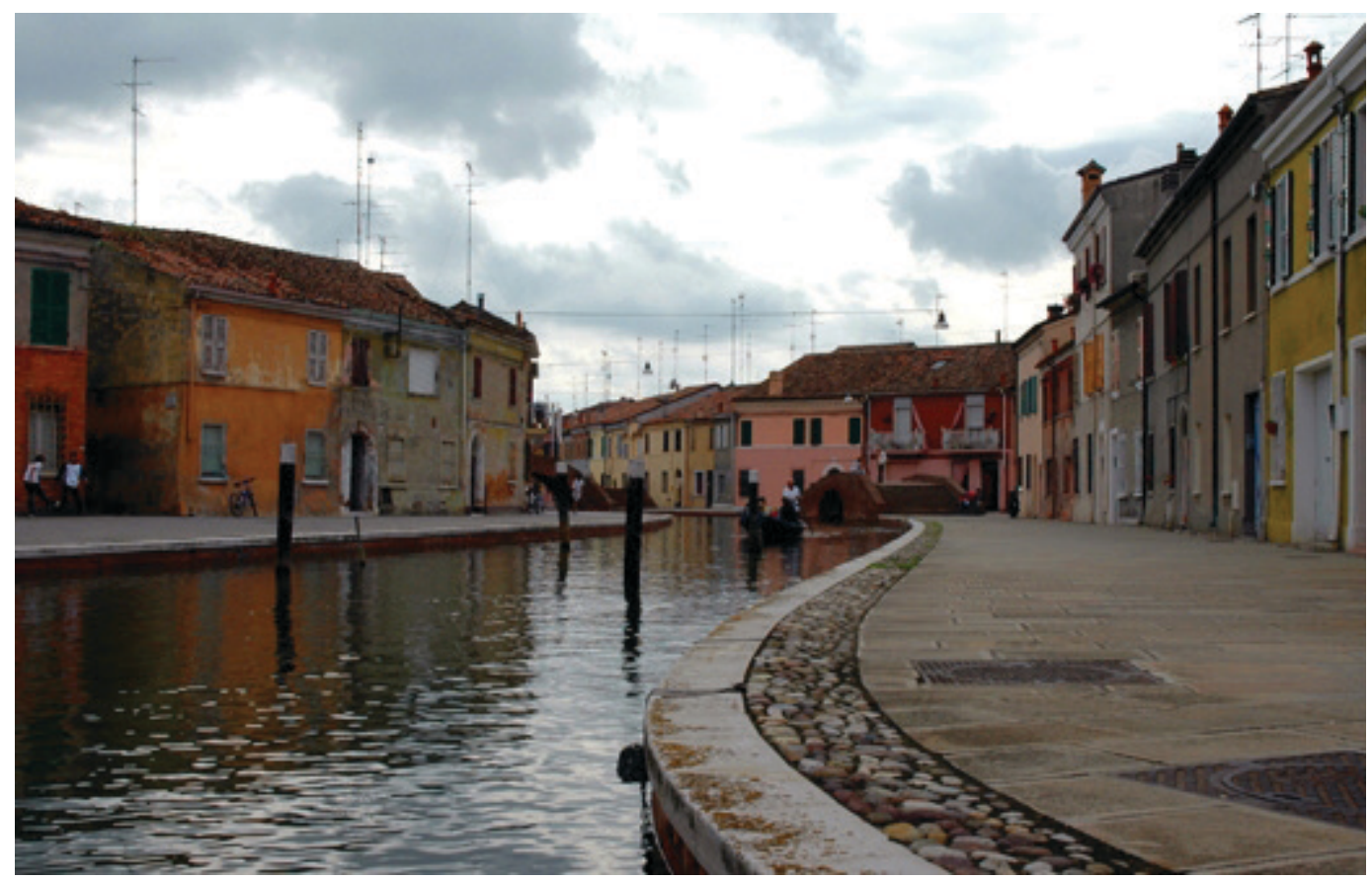

Canal Lombardo

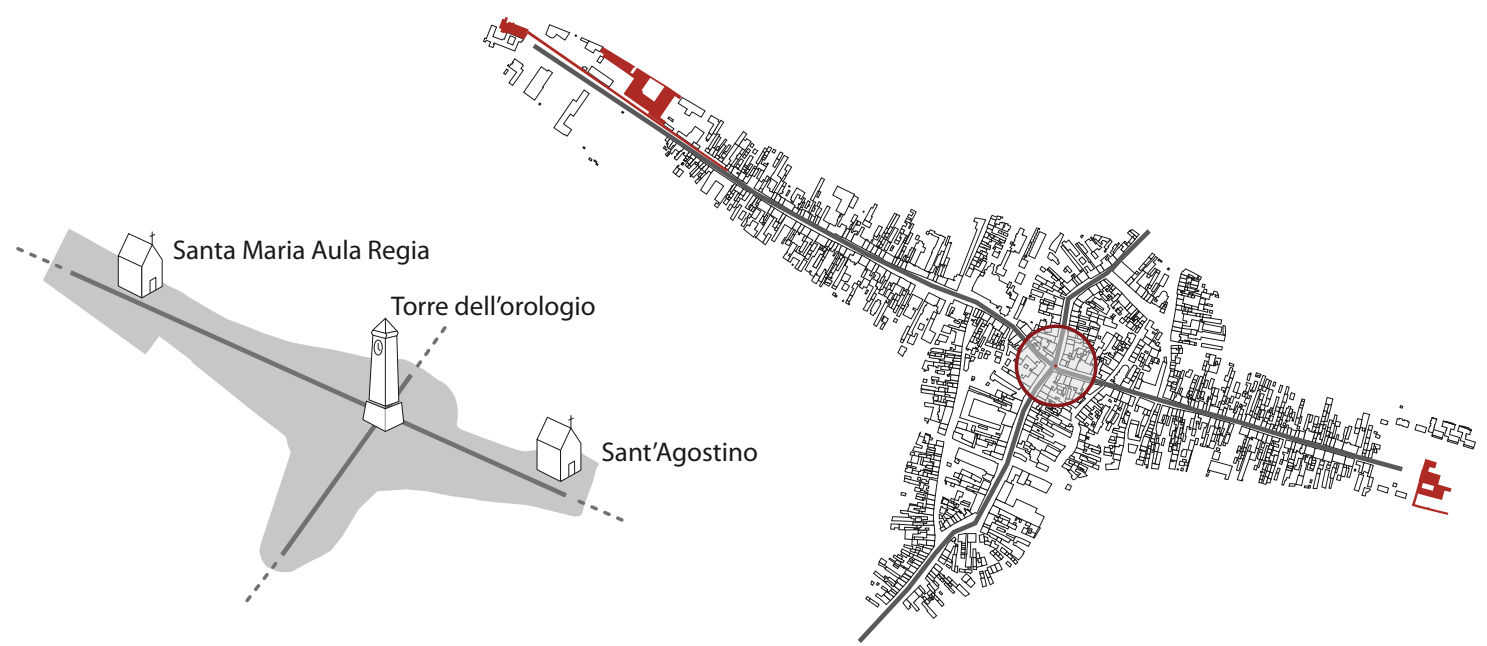

\section{Seguimento de habitações}

O tecido urbano do centro histórico tem uma configuração específica nas fachadas de frente para o canal perimetral: nestas zonas o meio urbano é composto por casas alinhadas ao longo de centenas de metros, de frente para a estrada, e habitações perpendiculares às anteriores, servidas por passagens 


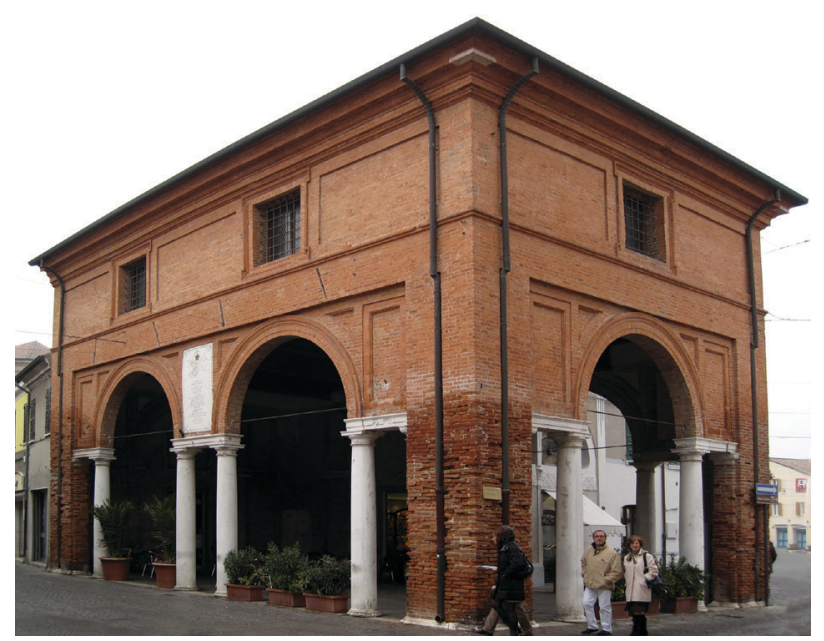

Casa do Trigo

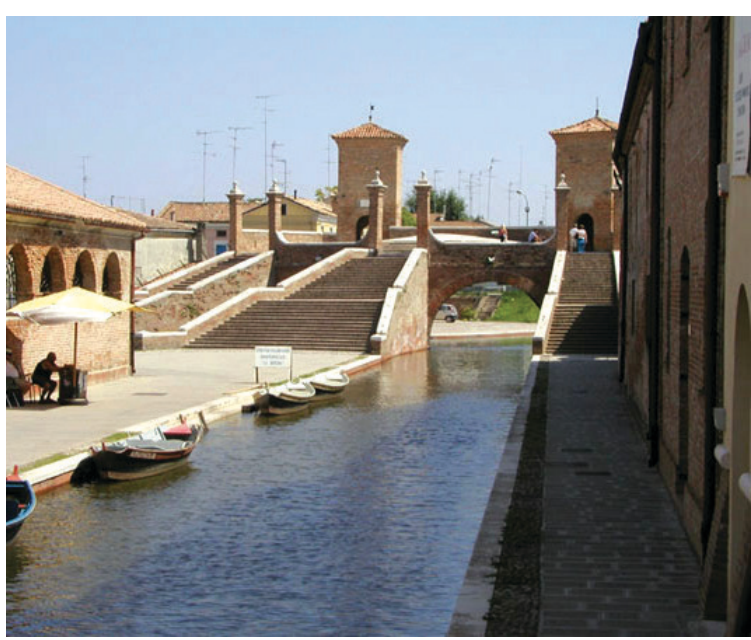

Três pontes

pedonais estreitas, às quais se acede através de pequenos vestíbulos, inseridos na fachada urbana, o que representa uma das características mais salientes de Comacchio. Depois das casas, geralmente, existem pequenas habitações que eram usadas para guardar equipamentos ligados à pesca e uma faixa verde utilizada como horto ou jardim, onde se punham a secar as redes da pesca. Hoje, muitas destas zonas são usadas para parques de estacionamento.

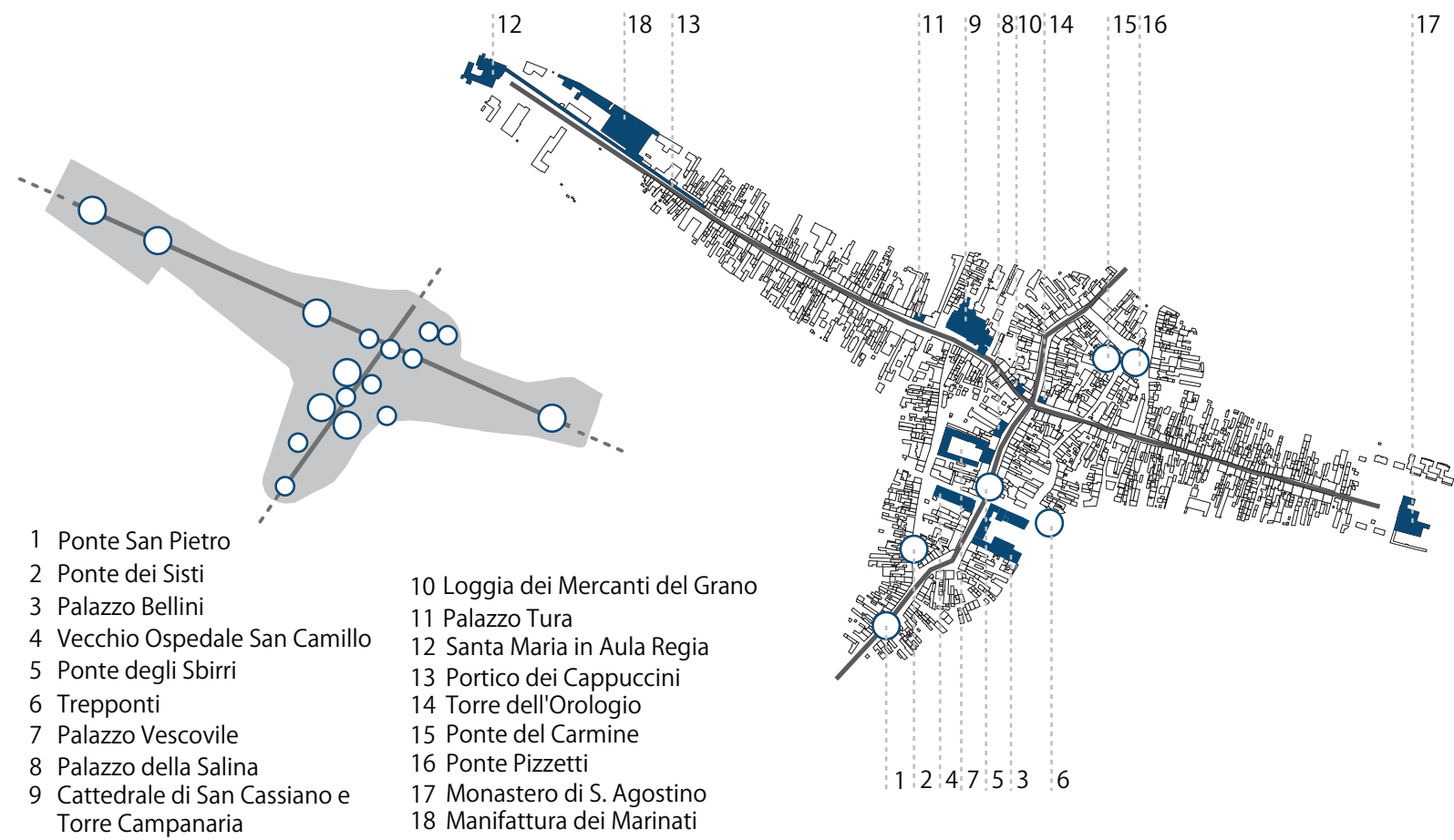



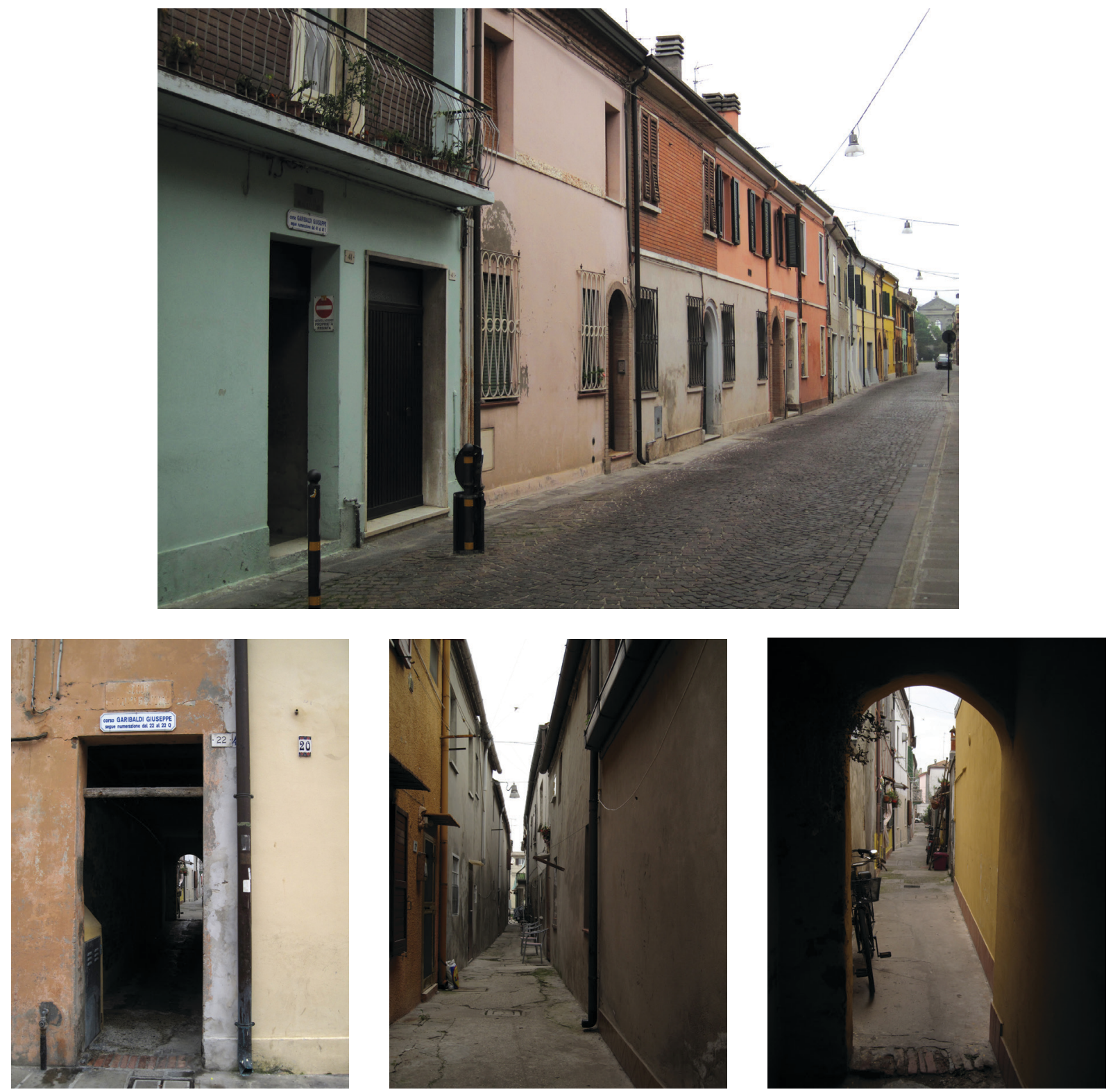

曧

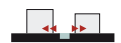

돌

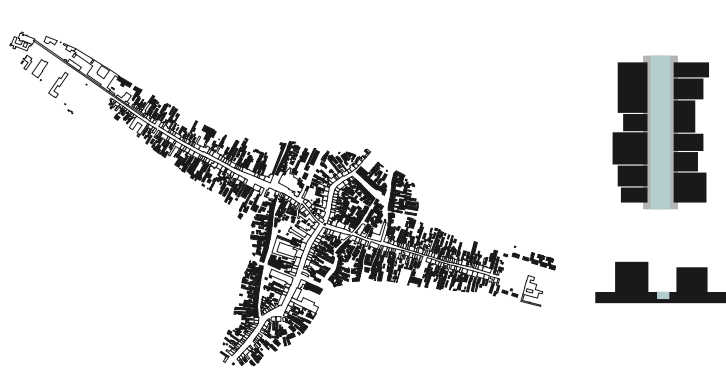

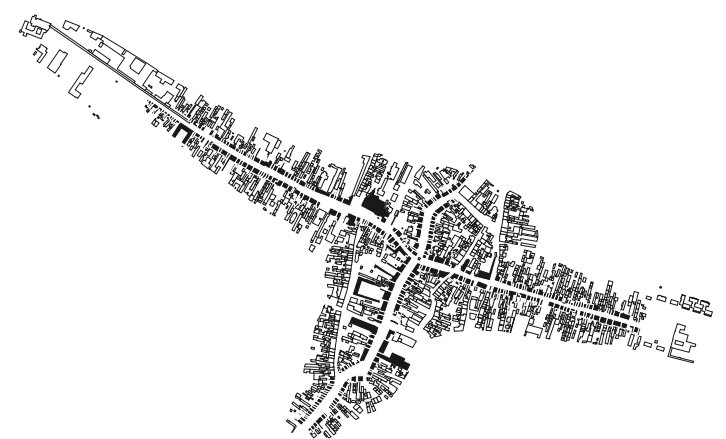




\section{Área de estudo}

Para o estudo escolhemos o sistema urbano composto pelo centro de Comacchio e as restantes cidades costeiras adjacentes (Porto Garibaldi, Lido degli Estensi e Lido di Spina) que constituem, atualmente, uma única conurbação. Esta situação tem origem numa série de causas:

- a presença, sobretudo em Porto Garibaldi e Lido degli Estensi, de uma população residente fixa durante todo o ano, que constitui a diferença mais evidente entre os dois centros e os restantes complexos turísticos do litoral de Ferrara;

- a deslocação, quase sempre para os aglomerados costeiros supramencionados, de uma série de serviços públicos e coletivos, entre os quais a escola municipal;

- a presença, entre Comacchio e o referido segmento da conurbação costeira, de uma série de equipamentos coletivos, além de territórios urbanizados, que criam uma ligação entre o centro do município e o litoral;

- as fortes deslocações pendulares quotidianas entre Comacchio e o litoral, consequência da necessidade de deslocação entre os diversos centros para se aceder à instrução, ao trabalho e ao tempo livre, impulsionado também pela pista ciclável na margem da estrada de Comacchio.

Este sistema representa, hoje, uma única conurbação, quer do ponto de vista da construção, sem dar soluções evidentes de continuidade entre os vários setores urbanizados, quer, sobretudo, do ponto de vista das dinâmicas sócio-económicas que ligam estes centros. A forte importância da água neste contexto urbano, a que se une a presença do Canal Navegável na via fluvial de Ferrara, que constitui uma verdadeira espinha dorsal de toda a conurbação, tornou este caso numa interessante área de estudo para se ativar a fase de inquérito e o laboratório de projeto, previsto pelo documento programático do Projeto "Água como património".

Esta escolha foi reforçada pela existência, nesta área, de zonas de degradação ambiental, urbana e sócio-económica que necessitam de urgentes intervenções de requalificação, que podem ser pensadas ao longo do laboratório de projeto.

\section{Área ex Eridania}

Esta antiga zona industrial está hoje desativada, após o fecho em definitivo da indústria de açúcar, em 1993, e a consequente demolição de algumas fábricas dez anos depois. De seguida, esta zona foi reabilitada. Este caso é interessante do ponto de vista da intervenção de requalificação urbanística e ambiental, dada a sua localização à entrada de Comacchio, ao longo de importantes vias de acesso ao centro habitacional, dispondo já de infra-estruturas de rede. Este local assume maior valor graças à presença, no subsolo, de vestígios arqueológicos do porto da antiga Comacchio que poderiam, se adequadamente recuperados, enriquecer a zona e convertê-la num ponto turístico. 


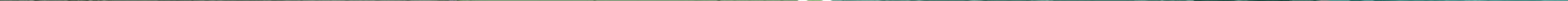




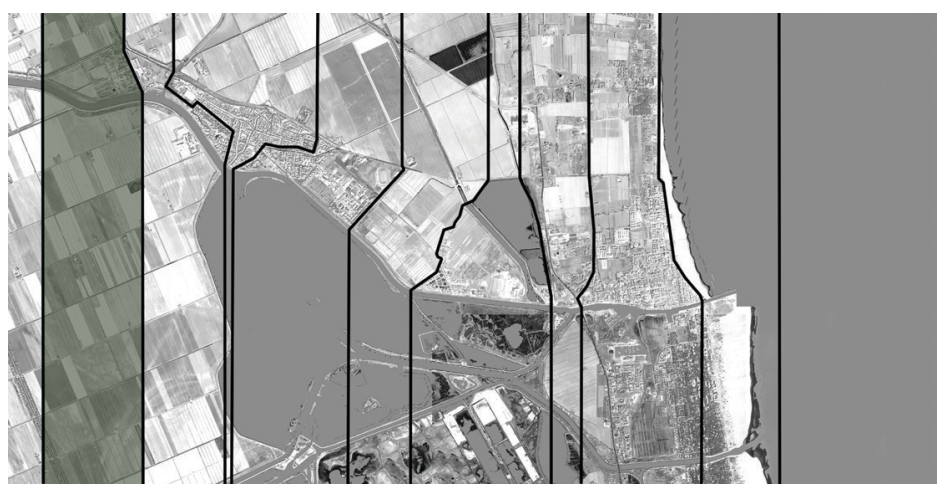

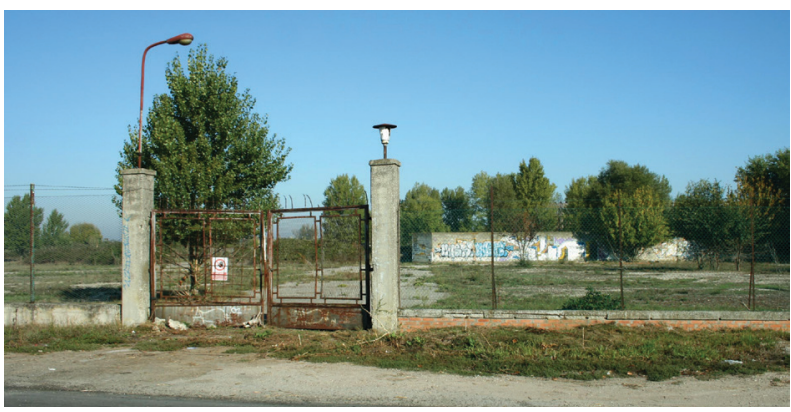

Entrada na SP15, "Via del Mare"

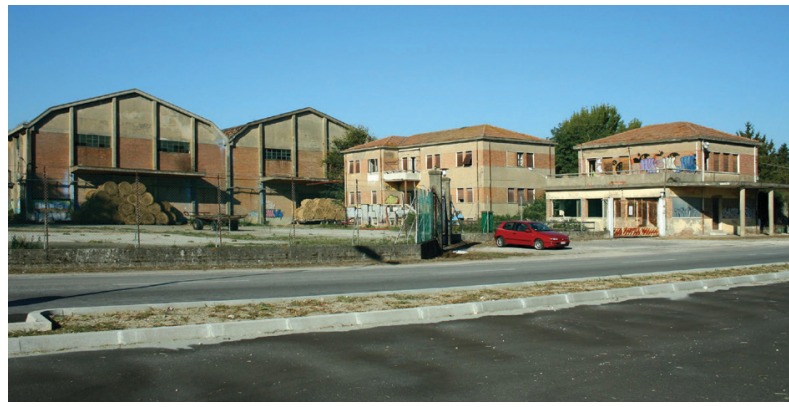

Complexo de edifícios atuais

\section{Habitação social}

O complexo de habitação social ao longo da Via Spina apresenta problemas evidentes de degradação estrutural e urbanística, devido à deterioração dos edifícios, à proliferação de anexos sem qualidade arquitectónica, à existência de edifícios de carácter produtivo, agora desadequados numa função prevalentemente residencial e, por fim, devido à ausência de projetos e manutenção dos espaços públicos e das relações, que provocaram um sentimento de negligência, além de fenómenos de apropriação privada sem justificação.

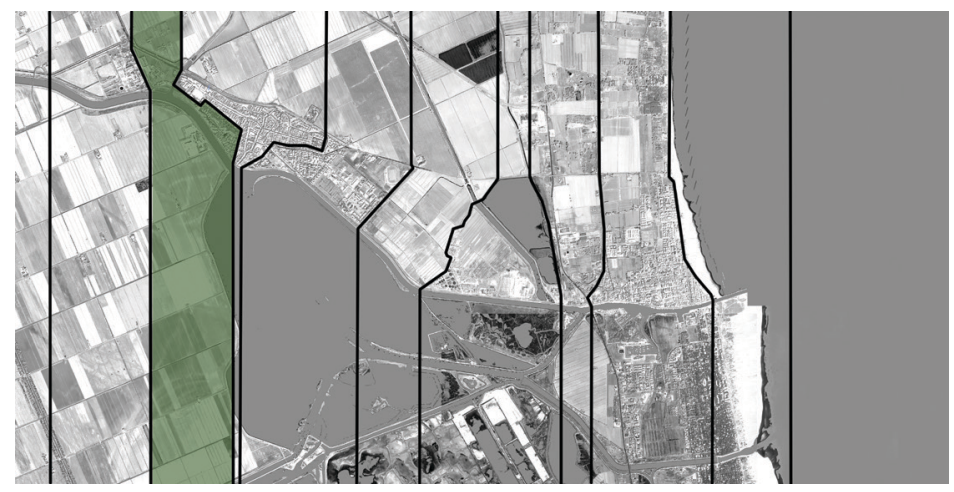




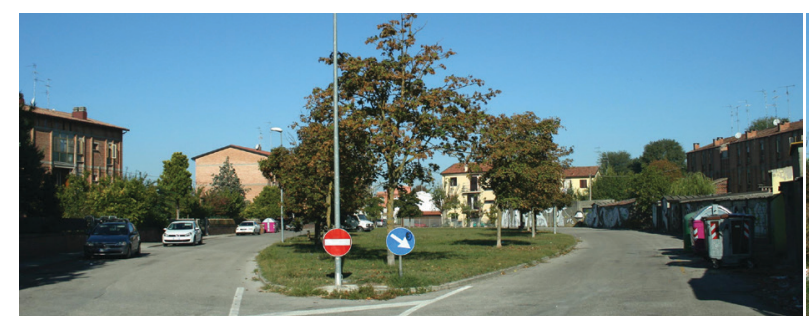

Zona verde, Via 2 de junho

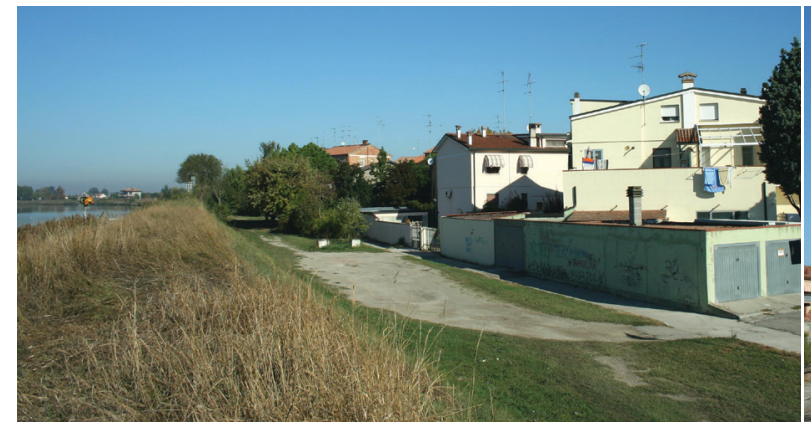

Visto do topo do represa

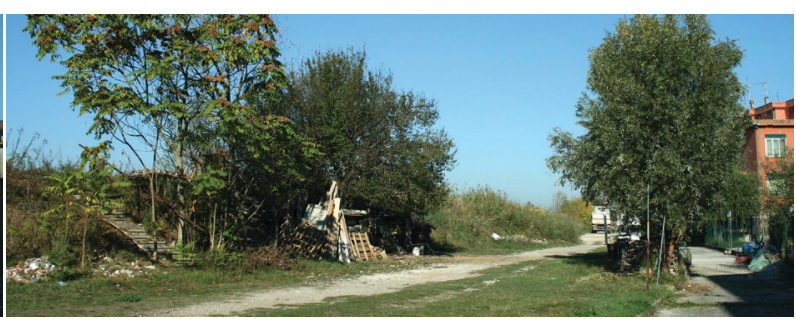

Vereda ao longo da represa

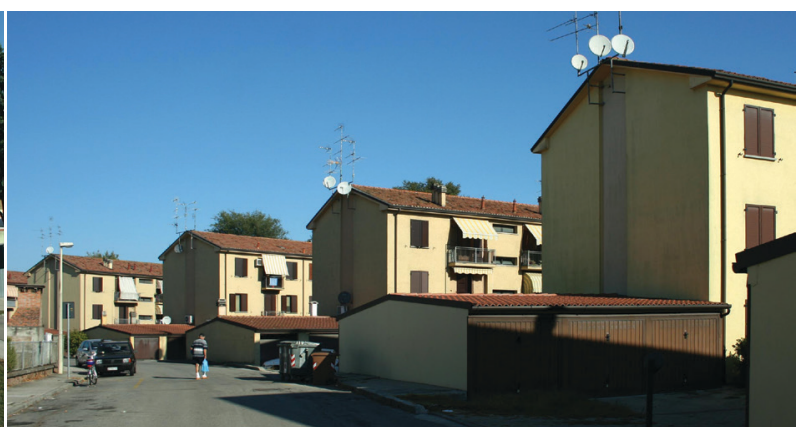

Habitações ao longo da Via Spina

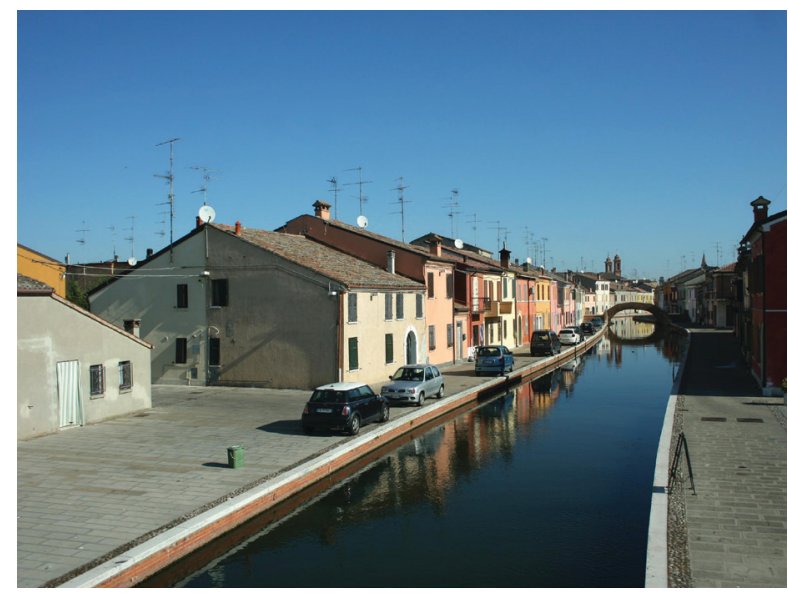

Canal Lombardo

\section{Centro histórico}

A relação entre o centro histórico de Comacchio e os seus vales parece, hoje em dia, quase inexistente, mesmo sob o ponto de vista perceptivo, se excluirmos o único ponto de observação, uma pequena torre de madeira junto à ponte de San Pietro. O complexo monumental de Santa Maria em Aula Regia, junto com o Portico dei Cappuccini, ao longo do qual se situa o acesso ao museu Manifattura del Marinati, necessita de intervenções de requalificação urbana, de forma a eliminar alguns edifícios de carácter produtivo desnecessários que em nada contribuem para a qualidade urbana da área. 


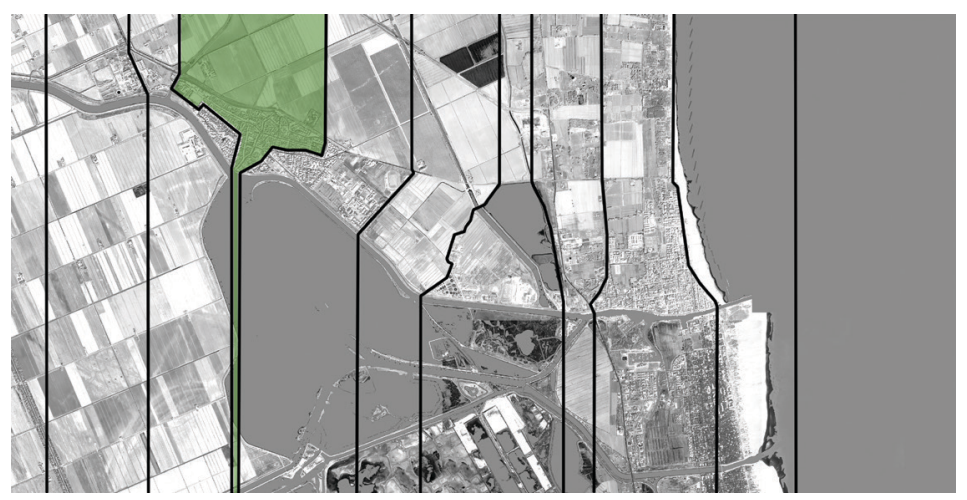

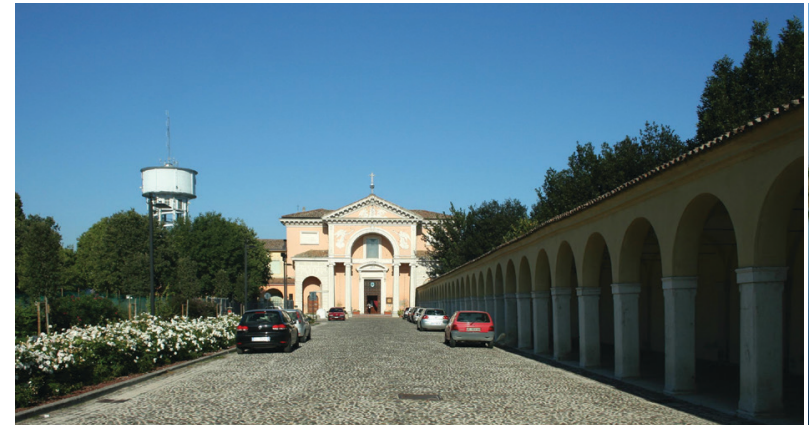

Santa Maria em Aula Regia e Pórtico dos Capuchinhos

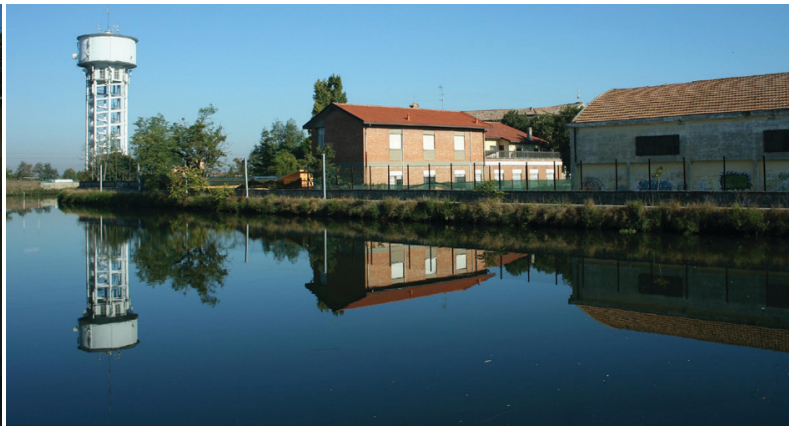

Doca turística ao longo da SP1

\section{Periferia}

As áreas residenciais construídas, ao longo do século XX, na parte oriental do centro histórico apresentam problemáticas recorrentes, do ponto de vista da qualidade urbana, de muitas outras periferias. Uma situação que parece ainda mais evidente no Quartiere Raibosola, onde se situam várias habitações sociais destinadas às classes mais desfavorecidas; são precisamente estes motivos que provocam a degradação dos espaços abertos e de convívio. Também algumas intervenções públicas, entre as quais o estádio municipal, não souberam melhorar a qualidade urbana. Ao invés, acentuaram a desordem perceptiva, fruto de projetos incoerentes e espaçados no tempo.

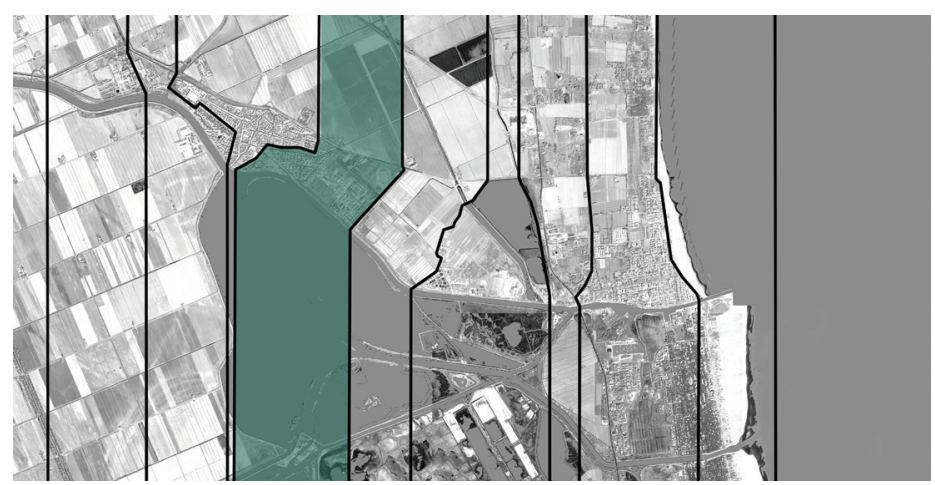




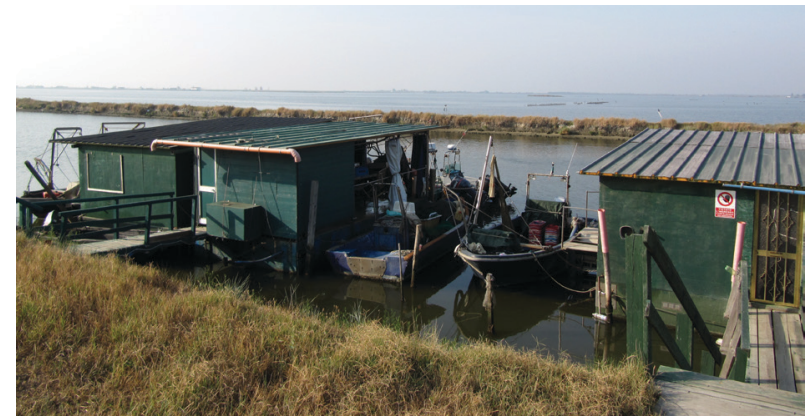

Os vales na borda do bairro Raibosola

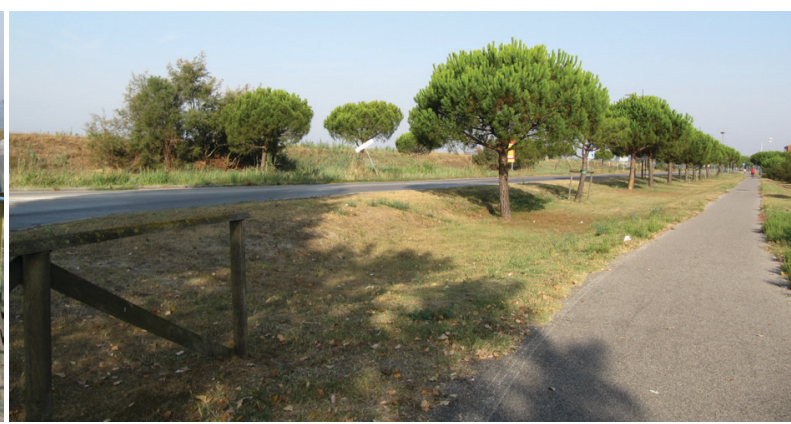

Pista ciclável ao longo da estrada SP1 - Estrada de Comacchio

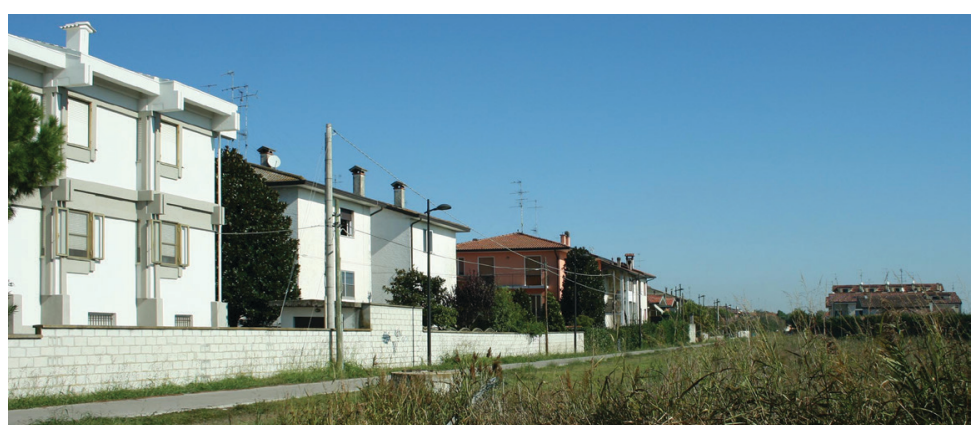

Habitações do bairro Raibosola

\section{O campo}

As zonas agrícolas residuais, entre Comacchio e a conurbação costeira, apresentam os mesmos fenómenos de degradação sob o ponto de vista ambiental e paisagístico da periferia do lado este: ausência de uma utilização efetiva do espaço, devido à má qualidade dos terrenos, que são pouco produtivos e com altos níveis de sal, a ausência de uma demarcação clara das zonas, a insuficiente demarcação das infra-estruturas existentes e a deslocalização de funções desadequadas. Esta zona está completamente desajustada com os elementos em seu redor, entre os quais os vales, tapados à vista por uma retenção de águas em betão. Se devidamente repensado, este local poderia ser uma oportunidade para a construção de um parque agrícola, ao serviço do centro habitacional e da conurbação costeira.

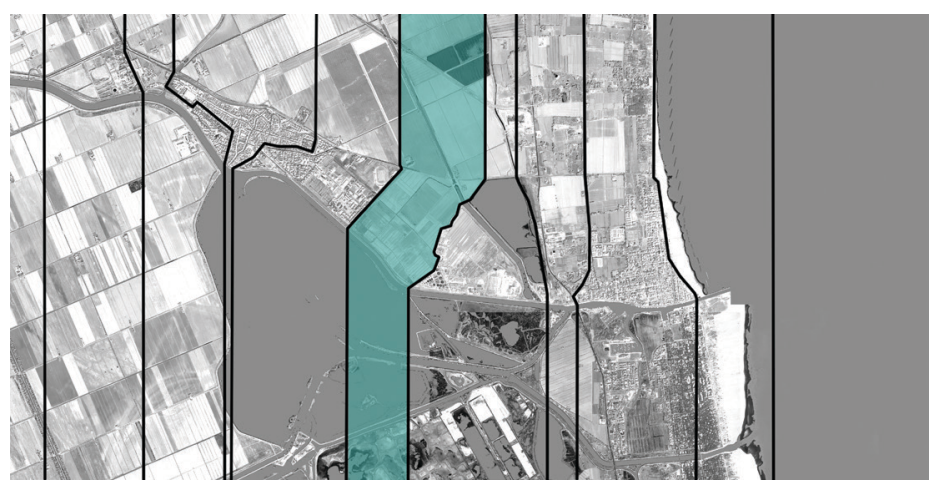




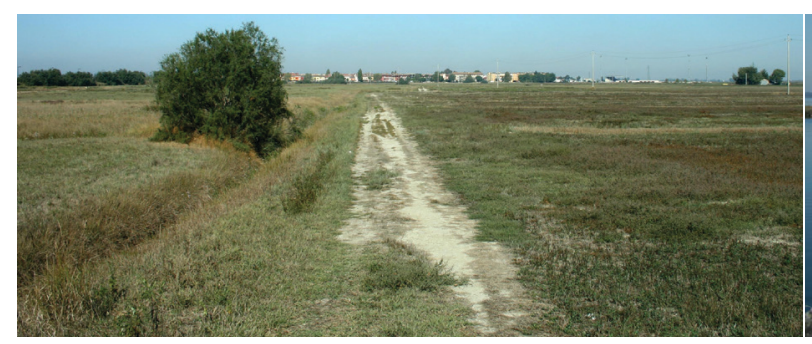

Paisagem agrícola residual entre Comacchio e a costa

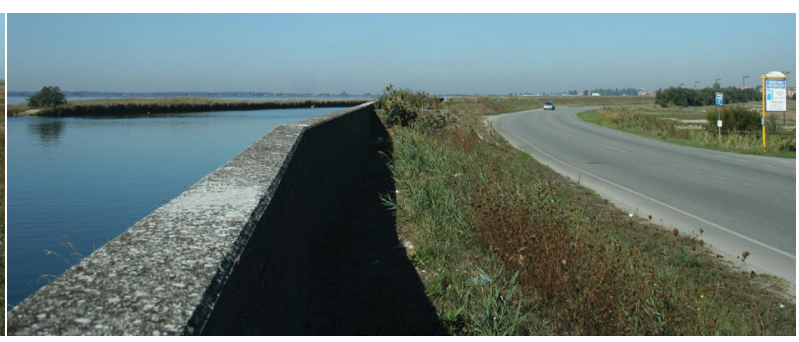

Represas artificiais ao longo da "Estrada de Comacchio"

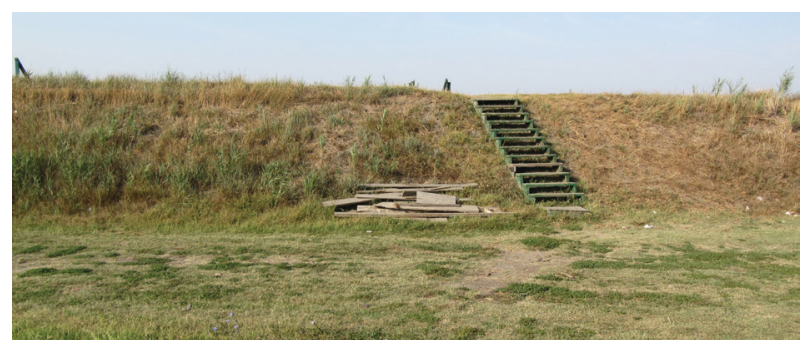

Terraplanagem do canal navegável

\section{Indústria}

Este setor tem como principal função a produção. Está localizado na parte ocidental da Strada Statale "Romea", e apresenta os mesmos fenómenos de degradação encontrados noutros transeptos da área de projeto.

Esta situação resulta também da crise económica, a qual afetou o setor produtivo e deixou atrás de si edifícios vazios, como é o caso da indústria Cercom. A mistura de atividades artesanais, a construção de má qualidade e os equipamentos públicos criam uma paisagem urbana caracterizada por uma desordem perceptiva evidente. Esta situação está presente também ao longo da via fluvial de Ferrara, que necessita, hoje, de intervenções de recuperação das margens, com a remoção de volumetrias não compatíveis com a protecção ambiental dessas zonas.

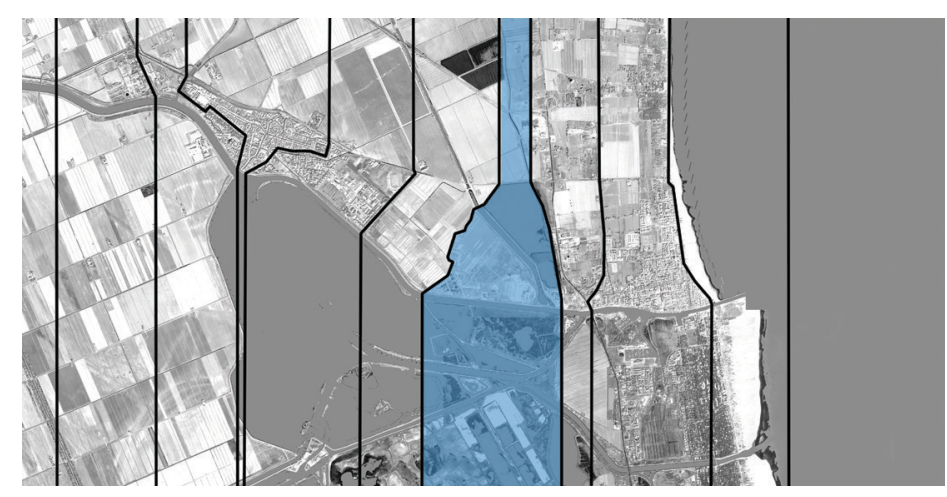




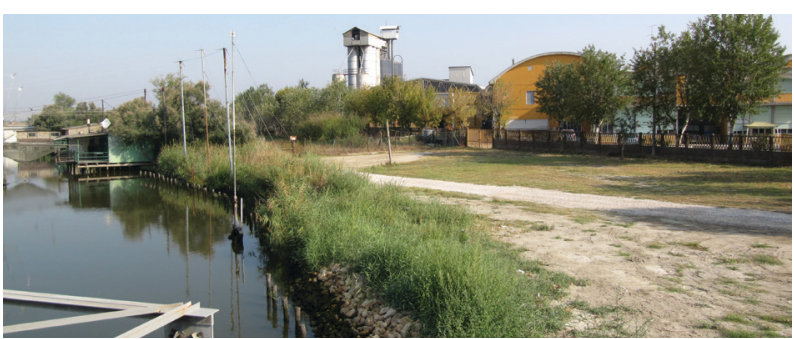

Canal navegável e margens do complexo industrial

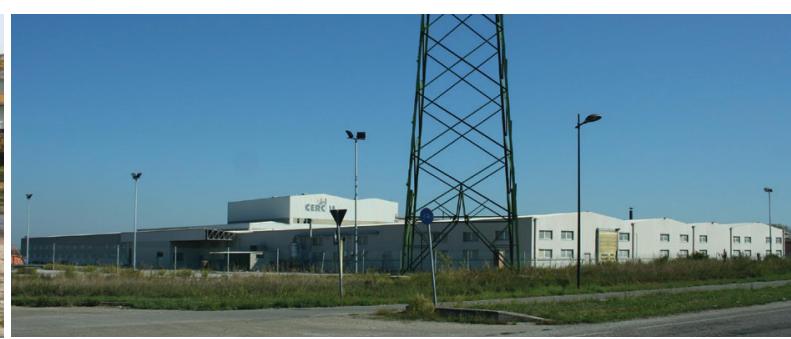

Indústrias Cercom

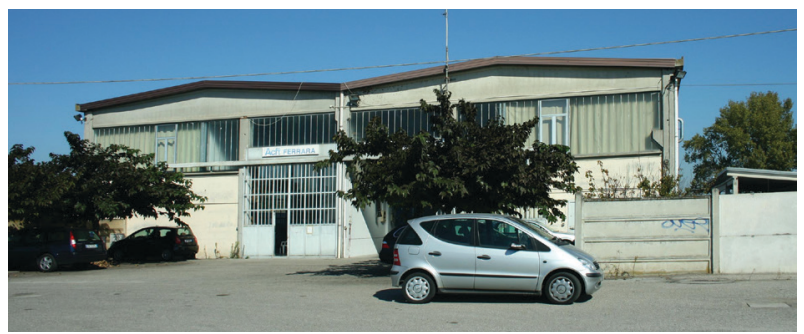

Atividades artesanais atuais

\section{Paisagem infra-estrutural}

A Strada Statale n. 309 tornou-se, ao longo dos últimos cinquenta anos, um percurso muito atrativo, não só pelas suas funções mais relacionadas com a viabilidade rodoviária, entre as quais a distribuição de reabastecimento de combustível, mas também pela variedade de atividades lúdicas e comerciais, como é caso de um centro comercial, um cinema multi-sala, uma zona de fast-food, que fizeram nascer, junto à estrada "Romea", "uma cidade de lazer", caracterizada por elementos típicos nestas situações: exploração intensiva das volumetrias concedidas sem investimento de projeto na qualidade arquitectónica dos volumes estereométricos, painéis publicitários berrantes, a presença de grandes parques de estacionamento e o predomínio de espaços rodoviários em relação às zonas ciclo-pedonais.

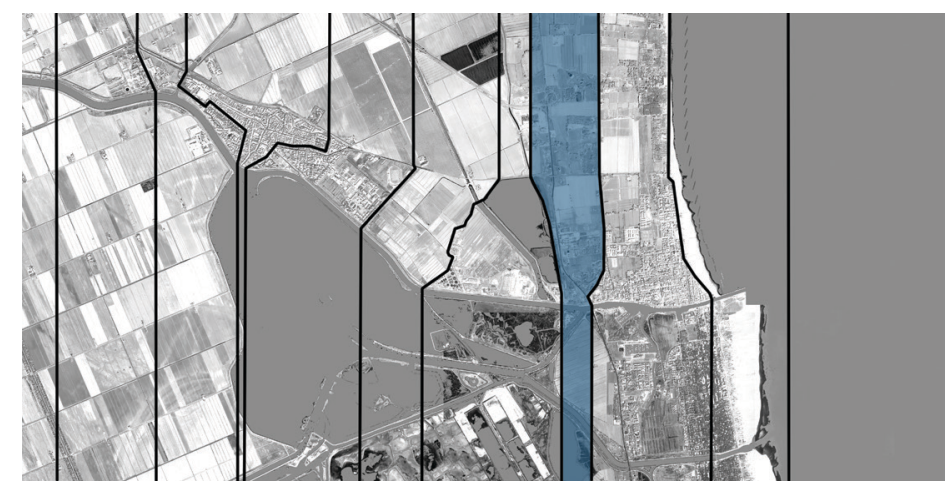




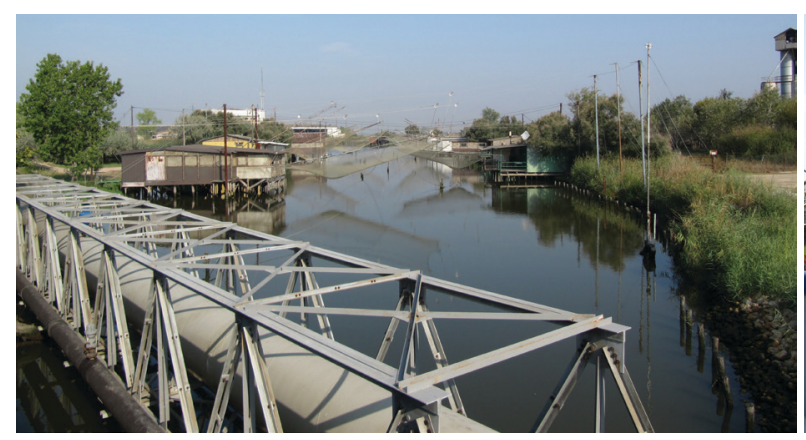

Bilancioni para pesca ao longo do canal navegável

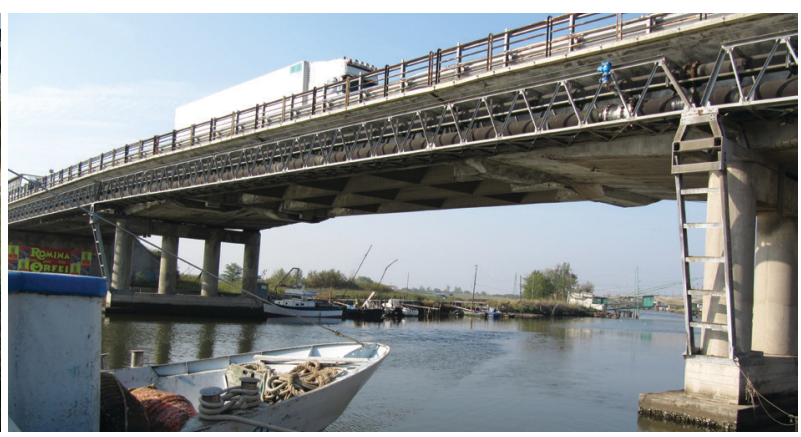

Ponte da estrada SS 309 "Romea"

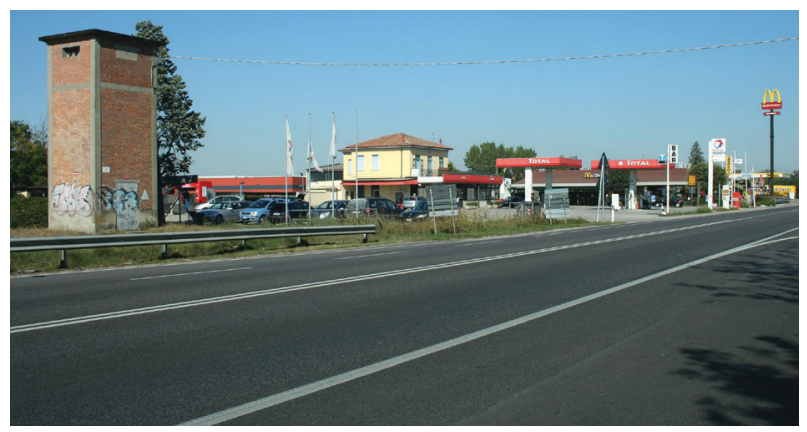

Infraestrutura comercial ao longo da SS 309 "Romea"

\section{Porto costeiro}

Porto Garibaldi é, entre as sete paragens do litoral de Comacchio, o mais urbano, aparecendo como um centro habitacional vocacionado para a pesca, e transformado, no pós-guerra, num complexo turístico. A presença de Porto Canale, com todos os instrumentos ligados à pesca, reforça a peculiaridade do espaço. Ao longo dos últimos vinte anos sucederam-se intervenções de requalificação urbana dos espaços públicos situados na margem do canal, com o intuito de aumentar a atividade turística, também por estar próximo de Lido degli Estensi (ao qual Porto Garibaldi está ligado através de ferry-boat), sede do pólo escolar superior de Comacchio e local muito frequentado, não apenas durante o período estival.

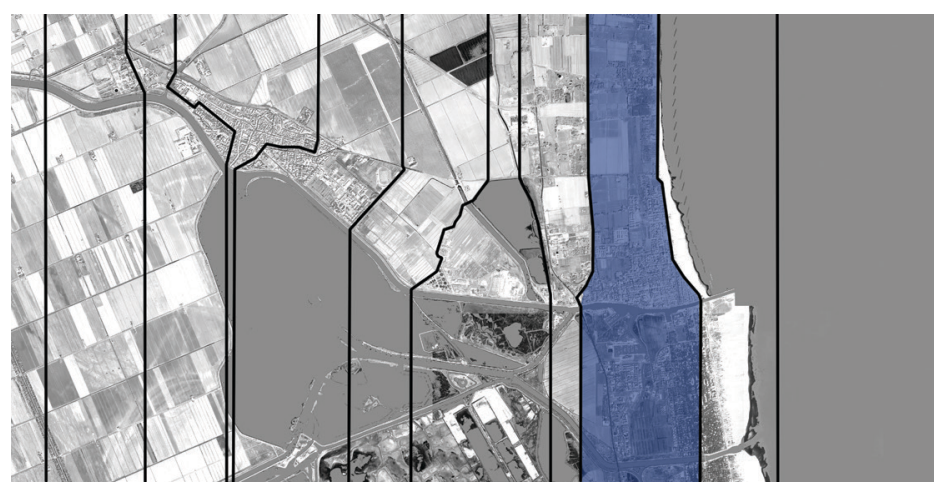




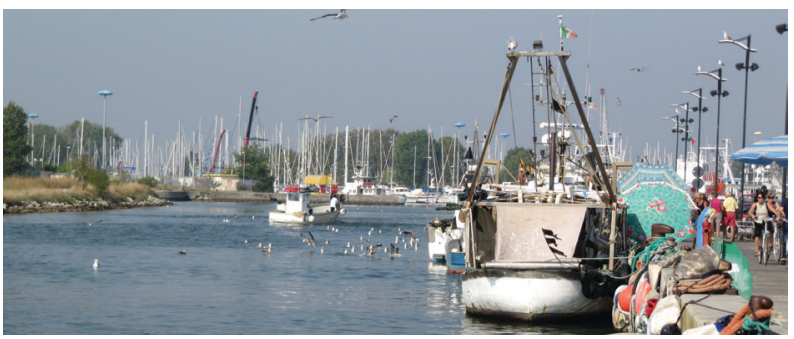

Embarcações ao longo do canal do porto

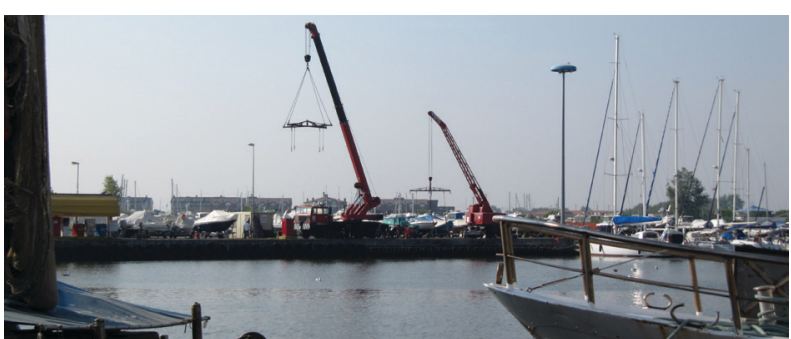

Canal do porto

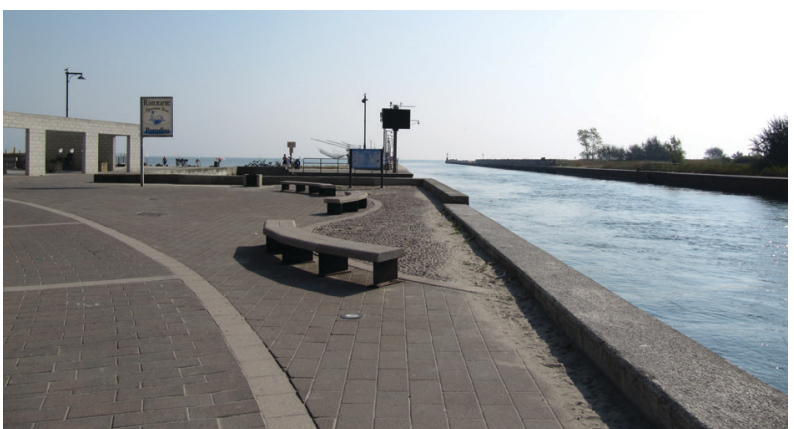

Passeio pedonal ao longo do canal do porto

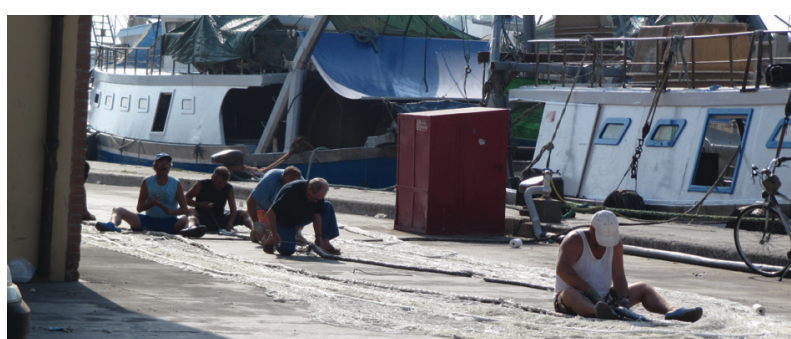

Atividades ligadas à pesca

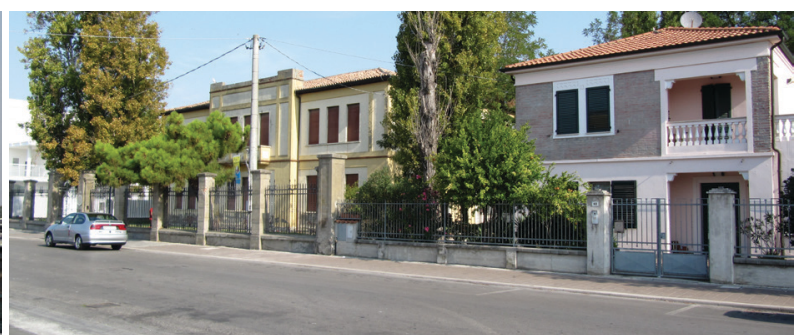

Habitações ao longo do canal do porto

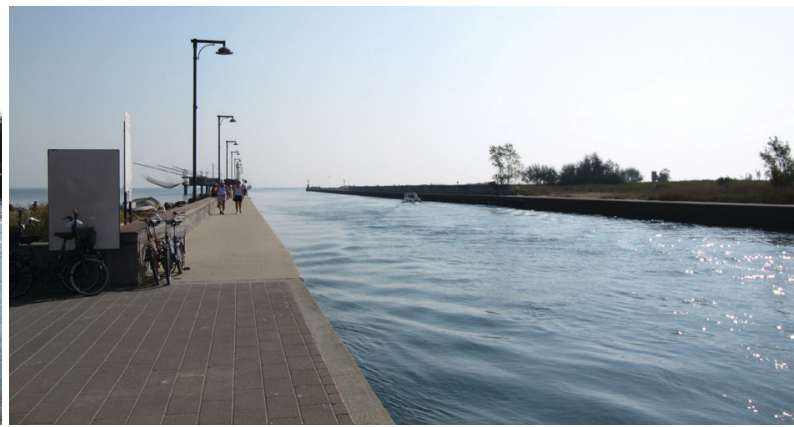

Foz marítima do canal navegável 


\section{Costa}

O troço terminal da via fluvial de Ferrara, situado na margem de Porto Garibaldi, foi, ao longo dos últimos anos, alvo de requalificações urbanas dos espaços públicos, com vista ao aumento da atividade turística, criando um agradável passeio que conduz, e se concluiu, na bandeira marítima do lado norte da entrada no porto. Atualmente, esse troço da via fluvial de Ferrara está a ser alvo de um importante projeto para construir uma saída até ao mar, o que implicará, entre outras coisas, a reestruturação da margem oposta ao canal, na margem de Lido degli Estensi.

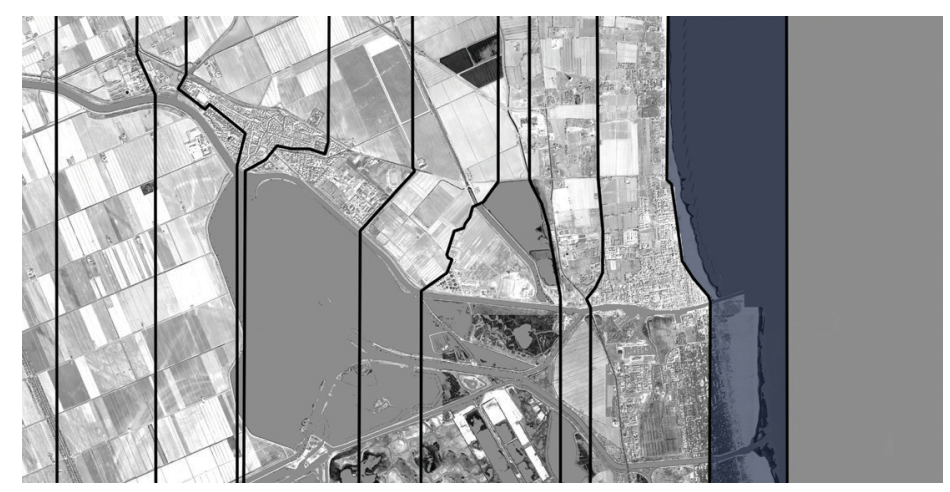

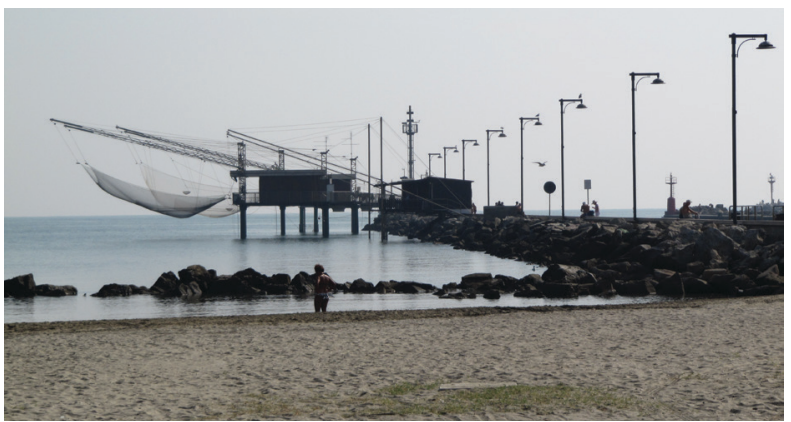

Molhe do canal navegável

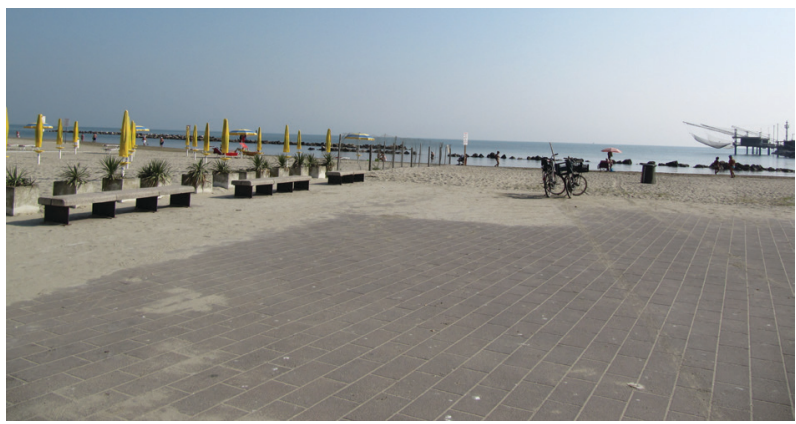

Equipamentos balneares na costa 


\section{LILLE \\ LEITURA DO TERRITÓRIO E ESTRATÉGIA URBANA (PARA A AGUA/PELA ÁGUA)}

RICHARD LEMEITER (Coordenador)

JULIEN PINON

CÉDRIC RIVIERE 


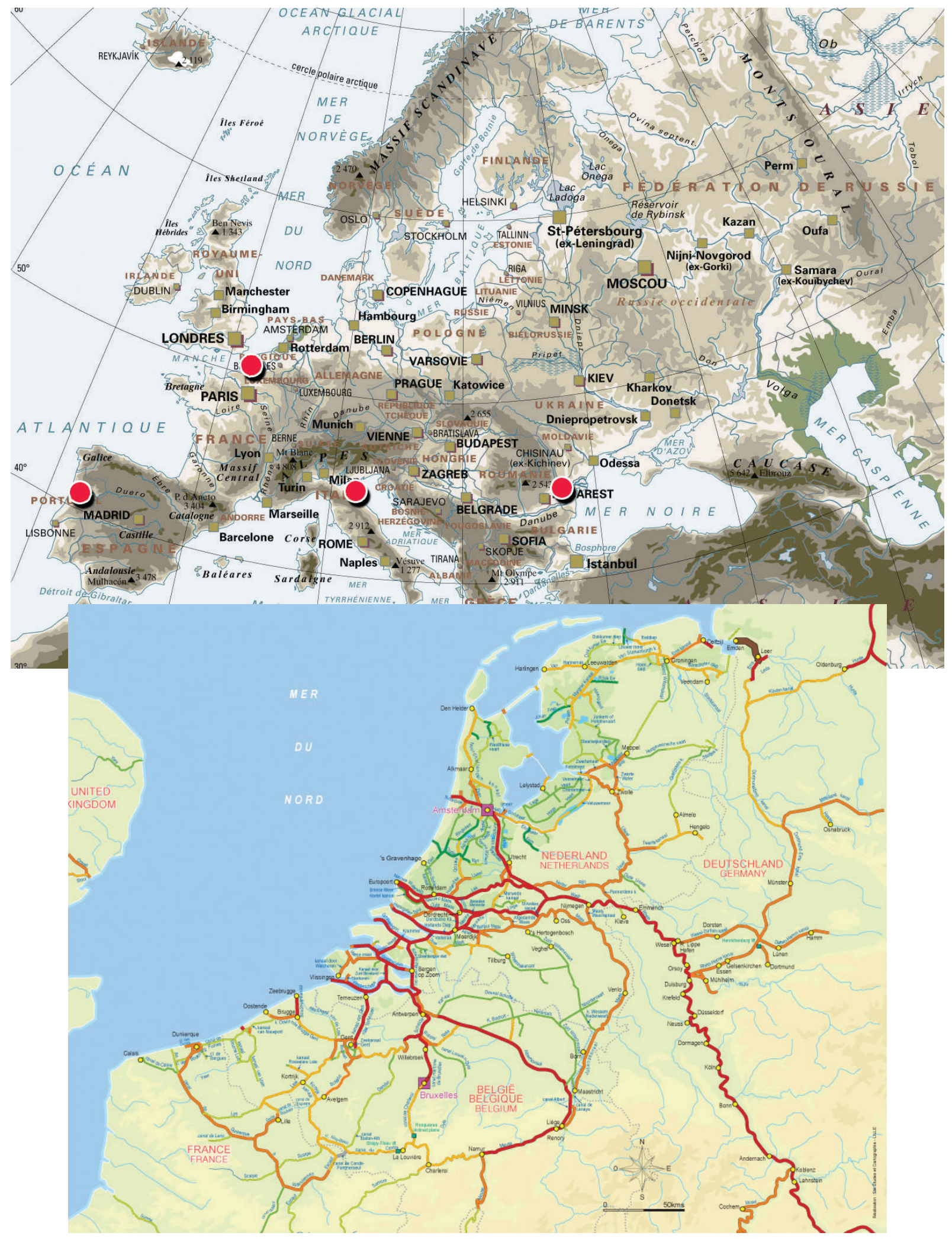




\section{Contexto}

\section{Lille e o programa europeu EPAT}

Desejosa de valorizar o seu rio e de reencontrar uma ligação entre a água e os seus habitantes, a Câmara Municipal de Lille comprometeu-se com o projeto europeu "A água como património: requalificação das paisagens urbanas fluviais". Trata-se de um trabalho de cooperação entre quatro cidades europeias que partilham o mesmo desejo: Braila na Roménia (sobre o Danúbio), Coimbra em Portugal (sobre o rio Mondego), Comacchio em Itália (no delta do Pó) e por fim Lille (sobre o Deûle). A finalidade é a troca de conhecimentos, de partilha de boas práticas a fim de melhorar as políticas de ordenamento e de reapropriação dos cursos de água urbanos dos territórios mencionados. Este trabalho materializa-se na produção desta obra e de uma exposição constituindo verdadeiros guias para outros territórios que se colocam as mesmas questões.

\section{O contexto regulamentar francês para abordar o projeto}

Em França, a lei sobre a água, de 3 de janeiro de 1992, consagrou a água como um bem. No seu primeiro artigo é afirmado que "a água faz parte do património comum da nação" e que "a sua proteção, a sua valorização e o desenvolvimento do recurso utilizável, respeitando os equilíbrios naturais, é de interesse geral". Esta "patrimonialização" de recursos de água encontra-se em numerosos países e regiões do mundo, particularmente no Ocidente.

Isto remete para diferentes abordagens do valor da água, considerando, por um lado, a água como recurso natural e por outro lado observando os usos ligados à água. A patrimonialização da água inscreve-se pois simultaneamente numa lógica de preservação, de valorização dos usos (passados, presentes e futuros) e dos lugares que lhe estão associados.

\section{A geografia de Lille}

"A água, fonte de vida, é aqui nascente de cidade. Contudo, Lille não nasceu de um grande rio, mas as suas ilhas, os seus ribeiros, os seus pântanos e os seus canais deram forma à sua história. [...] Por toda a parte, em Lille mas também nos concelhos à sua volta - e de modo mais alargado em toda a região - foi preciso procurar, domesticar, canalizar, aprovisionar e sanear. [...] aqui como em outros lugares, a água é preciosa e deve ser objeto de todas as atenções. A água é um trunfo essencial para o porvir da metrópole, bem como para o futuro da humanidade e de todo o planeta."

2001, Lille au fil de I'eau, Lille: La Voix du Nord, Pierre Mauroy 


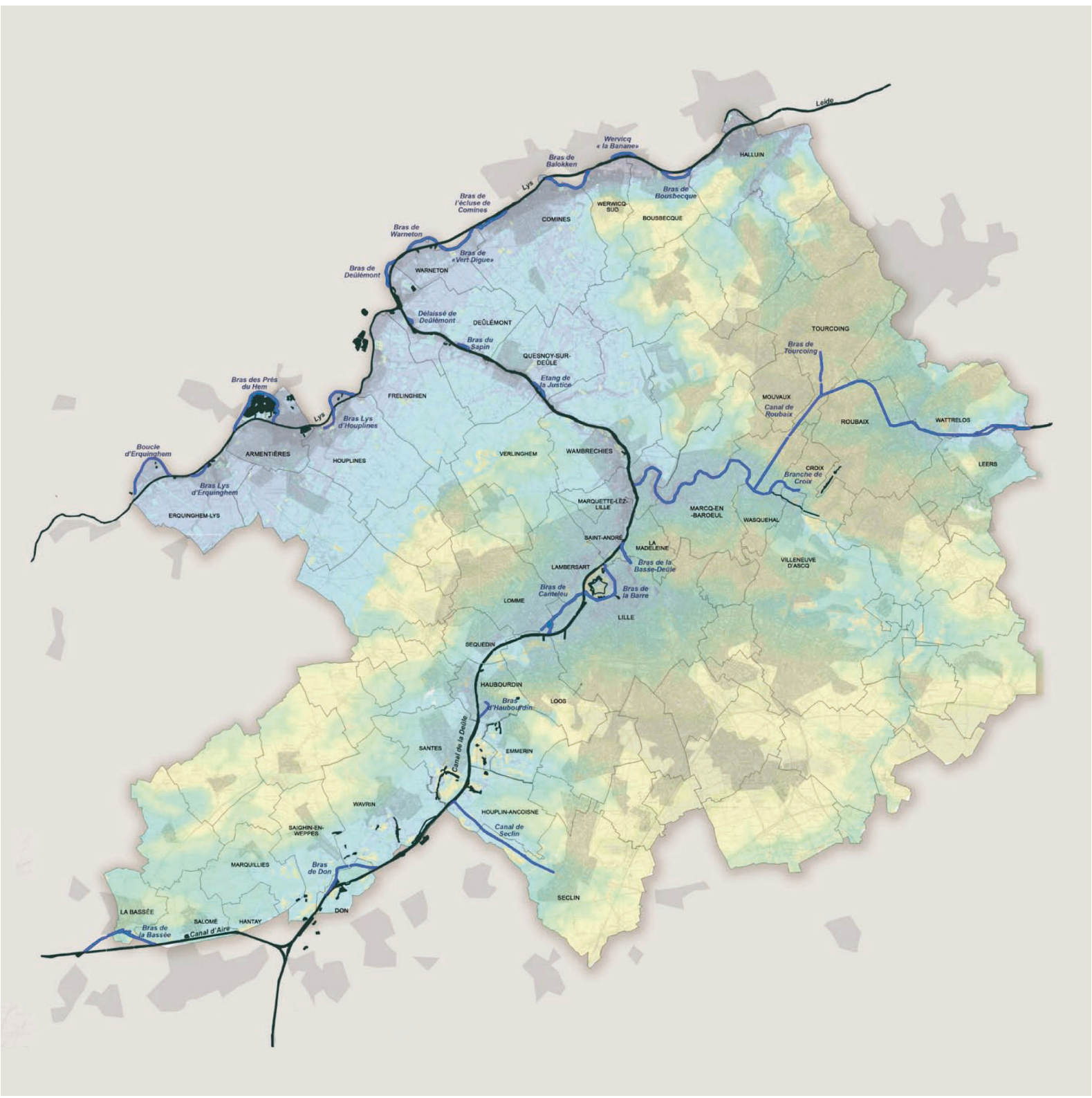

Os cursos de água (riachos, ribeiros, canais) representam atualmente no território metropolitano de Lille: $12 \mathrm{~km}$ de cursos de água dos quais $9 \mathrm{~km}$ navegáveis nos concelhos de Lille-Lomme-Hellemmes; $220 \mathrm{~km}$ de cursos de água, dos quais $84 \mathrm{~km}$ navegáveis, $60 \mathrm{~km}$ para o Deûle, no território de Lille Metrópole. O débito do Deûle é em média de $4 \mathrm{~m} 3 / \mathrm{s}$ em Wambrechies, a montante da confluência com o Marque. 


\section{Águas de superfície}

Historicamente, o território de Lille é um sítio de caráter fortemente húmido. Apresentava uma rede hidrográfica importante hoje desaparecida. O Deûle é o principal curso de água. Foi canalizado desde a Idade Média e o seu curso nunca cessou de ser modificado pelo ser humano. O Deûle tem a sua nascente em Carency no Pas de Calais, juntando-se-Ihe o Scarpe, a montante, e depois, no concelho de La Bassée, o seu débito passa para metade no canal de Aire em direção a Dunkerque. Por fim, junta-se ao Lys em Deulémont.

As funções dominantes do canal são: o transporte, o divertimento, mas tem também um papel hidráulico importante de drenagem no território que atravessa. O Deûle recebe as águas do canal de Marque Urbaine e do canal de Roubaix, servindo também de exutório para pequenos cursos de água e redes de saneamento dos concelhos vizinhos.

A supressão das bacias e vertentes hidrográficas e hidrogeológicas testemunha de uma comunicação entre o Deûle e o lençol freático do calcário. Em períodos de águas baixas, o lençol alimenta o Deûle e em períodos de águas altas é o rio que alimenta o lençol freático. Os poluentes vão pois do rio para o lençol freático e ao contrário. Depois de numerosos esforços para gerir as descargas no curso de água, o Deûle renasce enfim após ter sido um dos rios mais poluídos de França.

\section{Águas subterrâneas}

Globalmente, o subsolo da região de Lille é um verdadeiro mil-folhas de terras e de rochas diferentes através das quais a água circula mais ou menos rapidamente. Vários lençóis freáticos mais ou menos consequentes sobrepõem-se e encontram-se portanto a alguns metros debaixo dos nossos pés, com níveis que variam em função das estações e das bombagens.

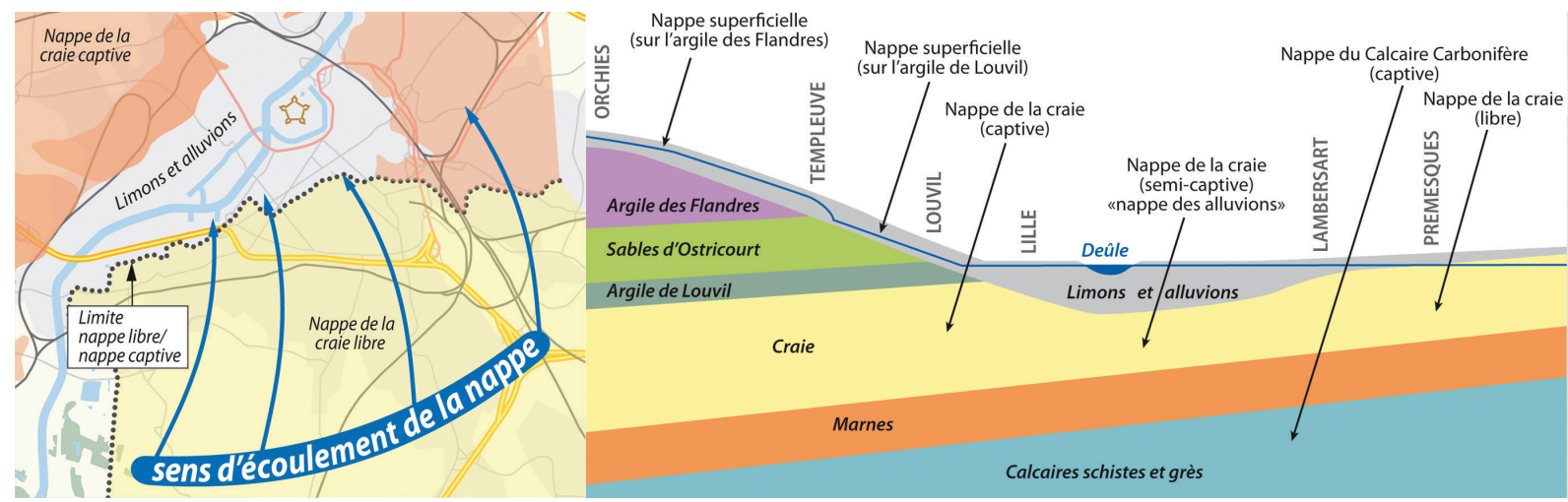




\section{A história de Lille}

O nome lembra o papel desempenhado pela água na cidade que construiu a sua história e a sua expansão graças a ela. "Trata-se de uma história tumultuosa entre a cidade e a água. Várias fases se foram sucedendo: a cidade alimentou-se da água, rejeitando-a em seguida a ponto de a renegar para, por fim, a reclamar de novo."

2001, Lille au fil de l'eau, Lille:

La Voix du Nord, Catherine Monnet

\section{L'Île-sur-la-Deûle}

Lille desenvolveu-se num sítio pantanoso e dotado de várias ilhas. O sítio foi por isso nomeado Isla, o que significa ilha em latim, e daí o seu nome atual, Lille. Os humanos instalaram-se nas margens do rio, e graças a ele conseguiram viver, levando a que, ao longo dos séculos, não cessassem de o domesticar, de o controlar, para dele tirar as melhores vantagens, antes de o rejeitarem progressivamente para fora da cidade no século XIX.

As descobertas arqueológicas revelam que o lugar foi povoado desde o Mesolítico por sucessivas populações, e que estas implantações estavam muito ligadas ao Deûle. No entanto, as implantações populacionais são muito ténues até cerca dos anos 750-800, período em que foi provavelmente criado o primeiro porto. No século IX o impacto das perturbações normandas provoca a fortificação de uma área habitada, ocupada por uma comunidade mercantil. A localidade é citada pela primeira vez em textos de 1066.

\section{Por que razão os humanos se instalaram aqui?}

Diversos braços de água enlaçavam as ilhas, com uma queda de água que, para os primeiros habitantes, representava uma fonte de energia. Uma primeira comunidade instala-se neste lugar que the oferece a possibilidade de atravessar o rio a vau, ao mesmo tempo que a queda de água obriga as primeiras embarcações a desfazerem-se da sua carga antes de passar o obstáculo, para recarregar a montante ou a jusante. Lille tem assim, pela primeira vez na sua história, uma posição de entroncamento.

Os numerosos cursos de água presentes na cidade são, ora ramificações naturais do Deûle e do Becquerel, ora testemunhos de antigos fossos protetores dos sucessivos recintos que nunca foram preenchidos, ou ainda canais escavados por razões económicas ou para ligar diferentes canais entre eles. 


\section{O rio Deûle no centro de todas as estratégias urbanas}

Até ao Renascimento, a água estava muito presente na cidade, no interior das muralhas e na base destas. Peleiros, curtidores de peles, fabricantes de papel, lavadeiros, talhantes, tintureiros e outros artesãos estabeleceram-se na proximidade da água, onde o gado e os animais de carga se desalteram, onde os portadores de água se vão reabastecer, onde os moinhos vão buscar a sua energia.

\section{A Cidadela}

Em 1667, Vauban decide implantar a Cidadela no lugar menos acessível das cercanias de Lille e no ponto mais baixo: escolhe pois um terreno pantanoso, impróprio para manobras militares de ataque. A Cidadela só podia ser atacada do lado da cidade, o quer obrigava o inimigo a empreender dois cercos de ataque: o da cidade e o da Cidadela. Os trabalhos, começados em 1667, terminaram em 1672

O plano de implantação da Cidadela foi pensado tendo a água como elemento defensivo a fim de interditar o acesso ao território (mediante inundação) mas também como elemento de ligação (através da navegação).

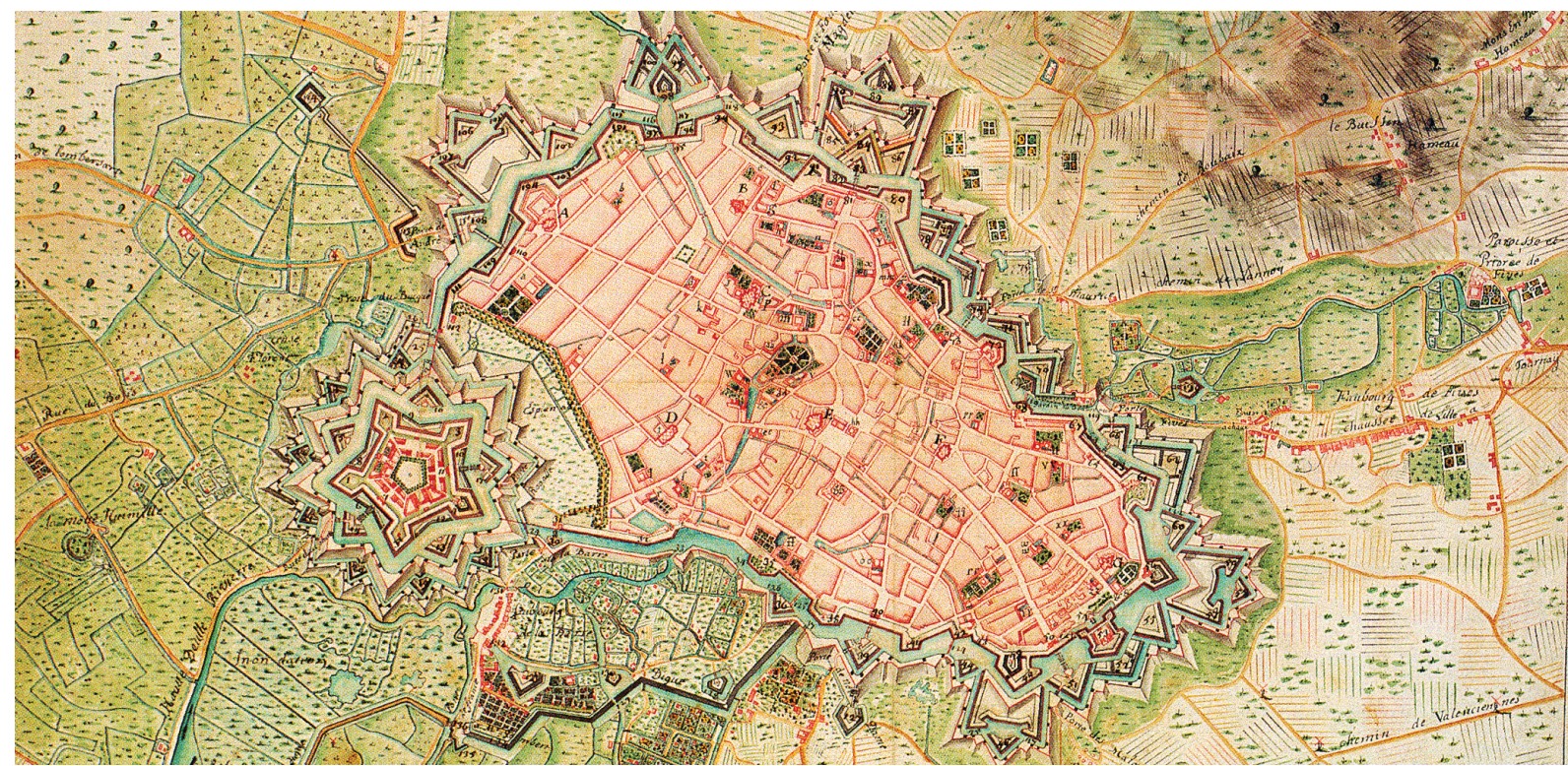




\section{O rio Deûle rejeitado para fora da cidade}

Perdendo a sua função económica no interior da cidade e cedendo ao espírito das Luzes que tendia a pôr fim às práticas de utilização da água, a cidade vai ser progressivamente "desidratada" durante dois séculos. Por volta de 1850, a construção do canal do Médio Deûle, inverte a problemática urbana da cidade de Lille. A água deixa de ser um fator de desenvolvimento no interior para passar a ser um sistema de navegação independente fora da cidade.

A ampliação de Lille, em 1858, modificou muito amplamente a rede hidráulica da cidade, cuja forma urbana deve ao mesmo tempo adaptar-se à chegada do caminho de ferro em 1848 . 0 transporte fluvial sofrerá doravante a concorrência do carril. Em contrapartida, para lá da via de água, é uma nova visão da água que se impõe na cidade: torna-se o elemento non gratus, e os canais são cobertos ou preenchidos.

O objetivo de maior salubridade vai motivar os grandes trabalhos do século XX. O plano de 1858 reflete o princípio de um enorme estaleiro e a remodelação em profundidade da cidade. A água já não é um elo de ligação entre os quarteirões. O Deûle forma uma barreira. Cada vez mais poluídos, os canais interiores vão ser progressivamente preenchidos até desaparecerem.

No início do século XX, os antigos canais são transformados em esgotos. Nos anos 30 começam os trabalhos de preenchimento do Baixo-Deûle e acabam nos anos 60. Em 1948, é criado o Porto fluvial, reforçado pela escavação do canal de grande dimensão nos anos 70 .

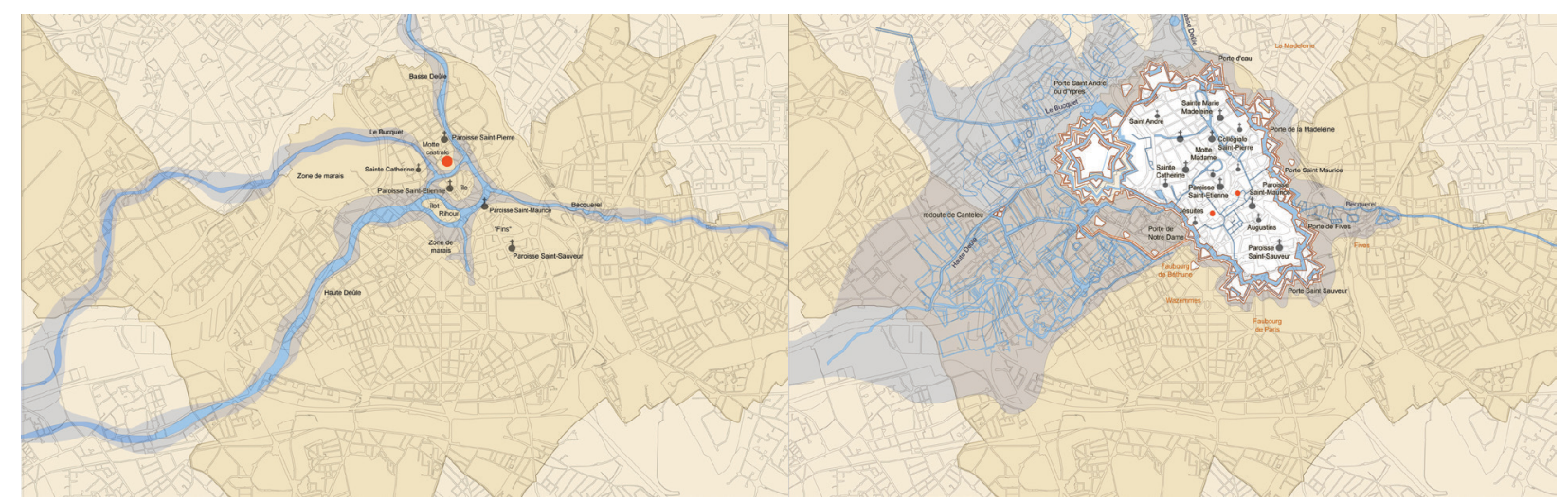

Ano 1000, os homens instalam-se nas ilhotas no meio do pântano. O curso de água passa pelo coração do que é hoje o centro da cidade.
A intervenção de Vauban, no final do século XVII, marca o apogeu do uso da água como sistema defensivo e comercial.

\section{Síntese}

Espaço identitário, o rio Deûle e os seus antigos canais constituem um elemento de memória do lugar, um bem transmitido, um património que hoje importa revelar e tornar acessível ao maior 
número de pessoas. Trata-se de inventar para ele um novo destino, novos usos, a fim de o pôr em acordo com as aspirações e necessidades da época.

Lille nasceu da água e, depois, virou progressivamente as costas ao seu rio. No presente, é tempo de fazer de novo falar a água e recriar laços com o Deûle. Projetos urbanos como o das Margens da Haute-Deûle com Euratechnologies começaram a empreender esse trabalho de costura do território. Outros se seguirão, tal como o porto e a estação de água de Lomme mas importa não limitar a intervenção ao urbanismo, ao ordenamento da via de água e pensar a atividade económica, a vida à beira da água. A invenção de um novo destino para esta rede capilar complexa e sensível e a promoção de novos usos, com vista a uma resposta em conformidade com as aspirações e as necessidades do nosso tempo, é uma tarefa de todos (eleitos, técnicos, empresas, associações, habitantes).

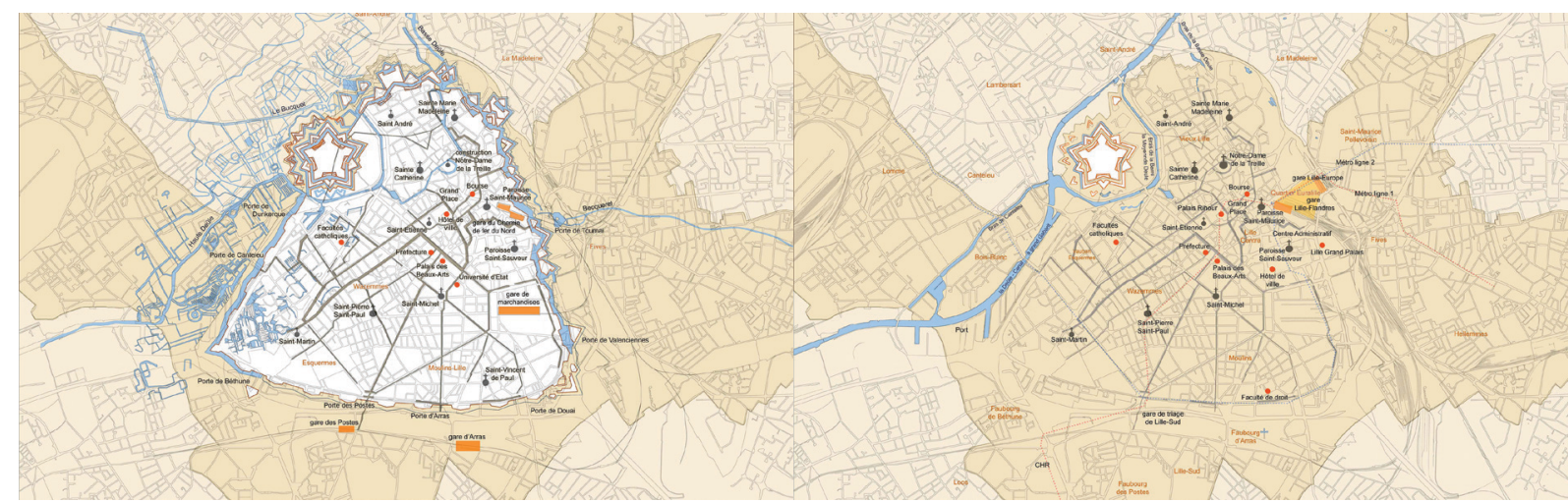

1858 - A cidade acaba de ser ampliada, anexando os arredores a sul. É o início do desaparecimento da água.
Anos 70 - Criação do canal de grande dimensão, última grande intervenção sobre o nosso território. Início da redescoberta da água.

\section{Leitura do território e estratégia urbana (para a água/pela água)}

\section{Diagnóstico do território}

Metodologia: Realização de visitas de terreno que revelaram características próprias de cada espaço (acessibilidade, morfologia, usos) e permitiram distinguir as situações urbanas e paisagísticas muito contrastadas.

O recorte distingue as situações, associando cada entidade a um espaço público ligado à via de água, determinando no seu funcionamento e no seu desenvolvimento. 


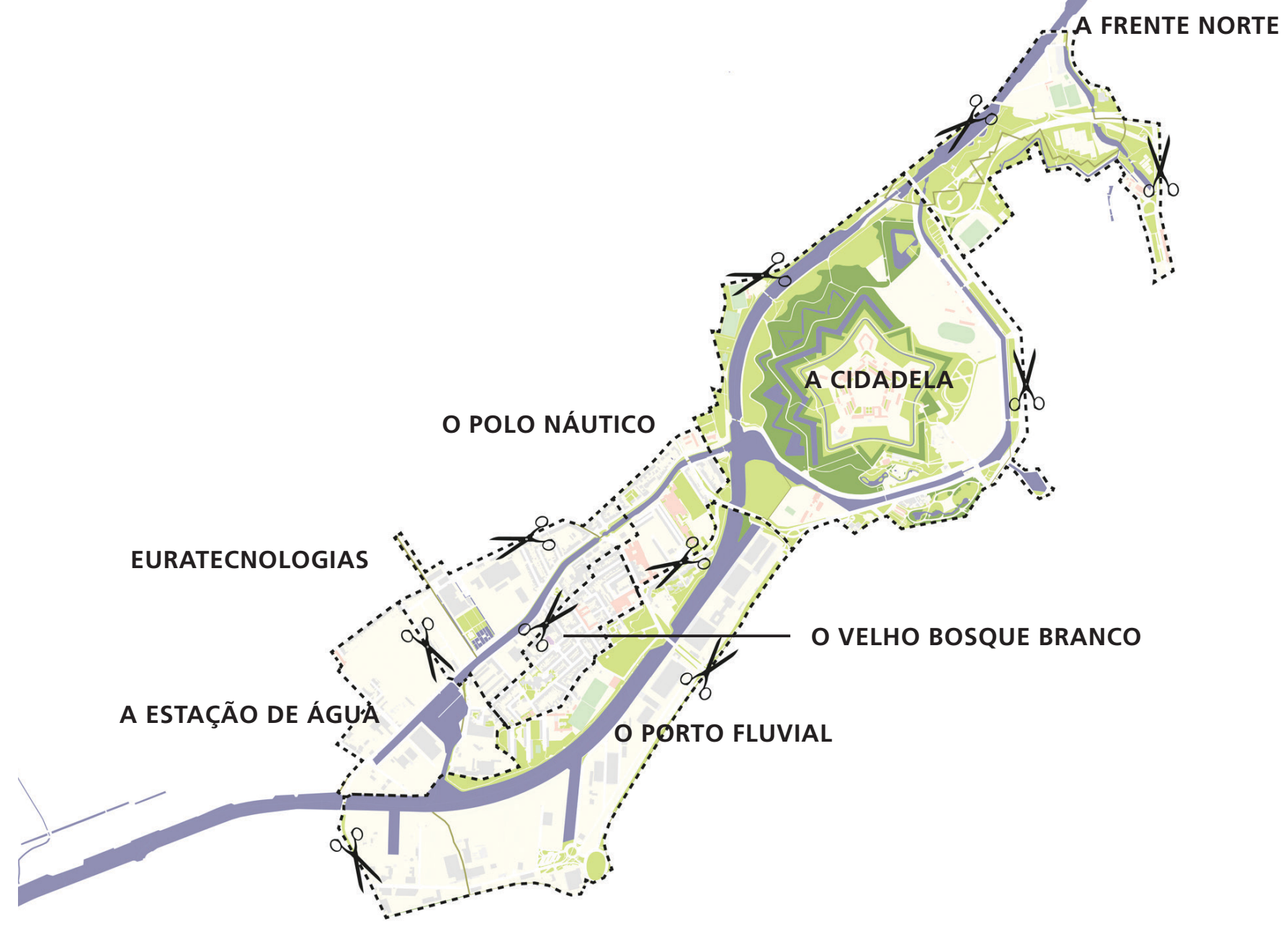




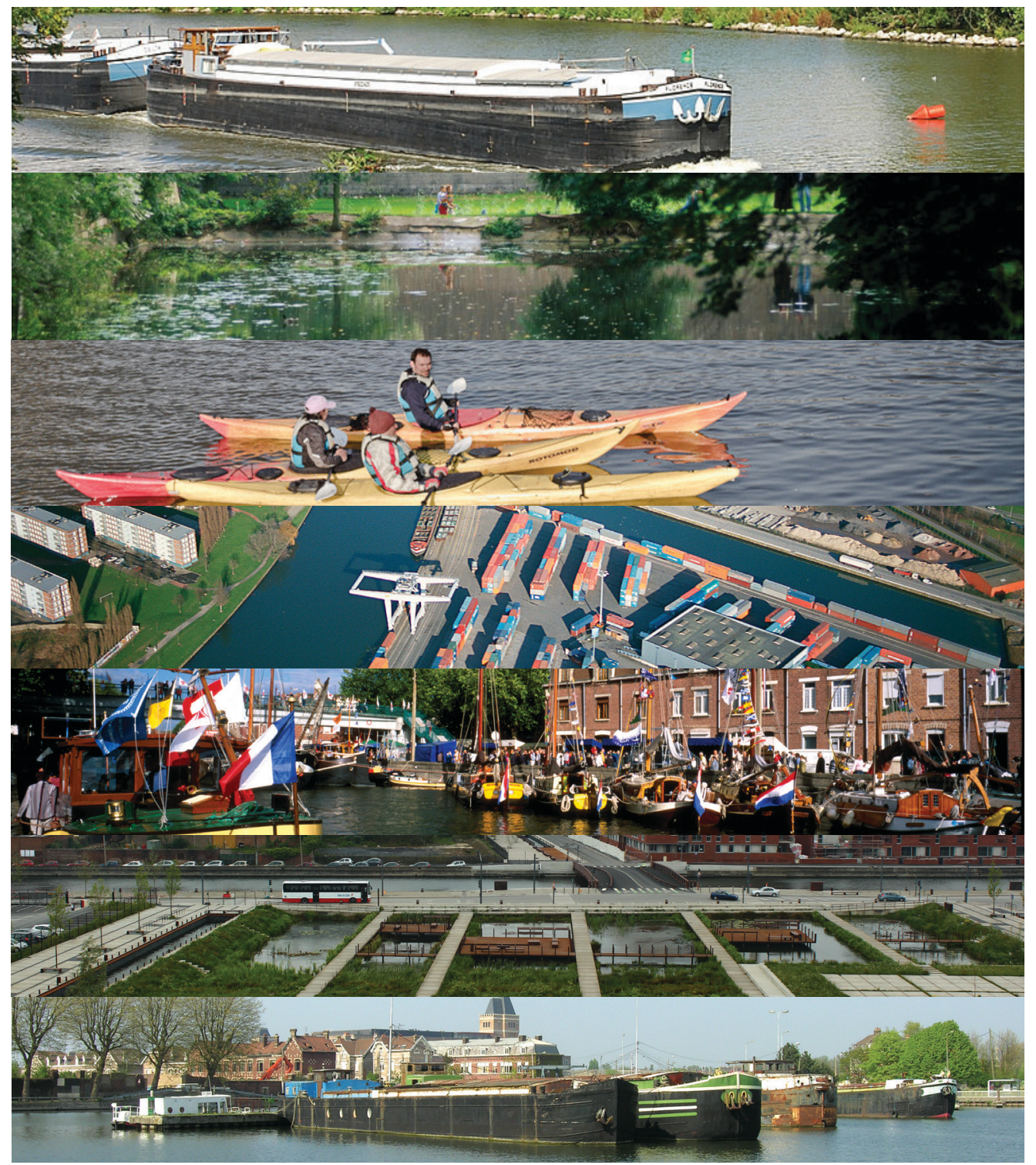

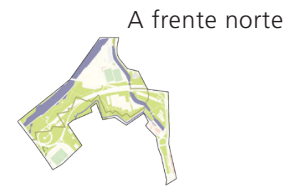

A Cidadela

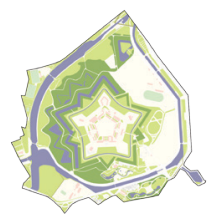

O polo náutico

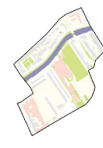

O porto fluvial

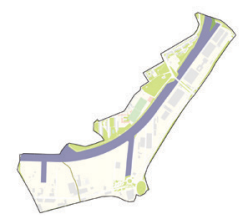

O velho bosque branco

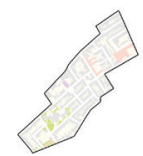

Euratecnologias

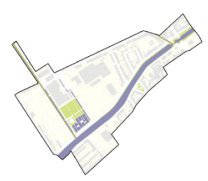

A estação da água

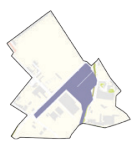


Vista aérea de Lille - Setor Oeste - 2003

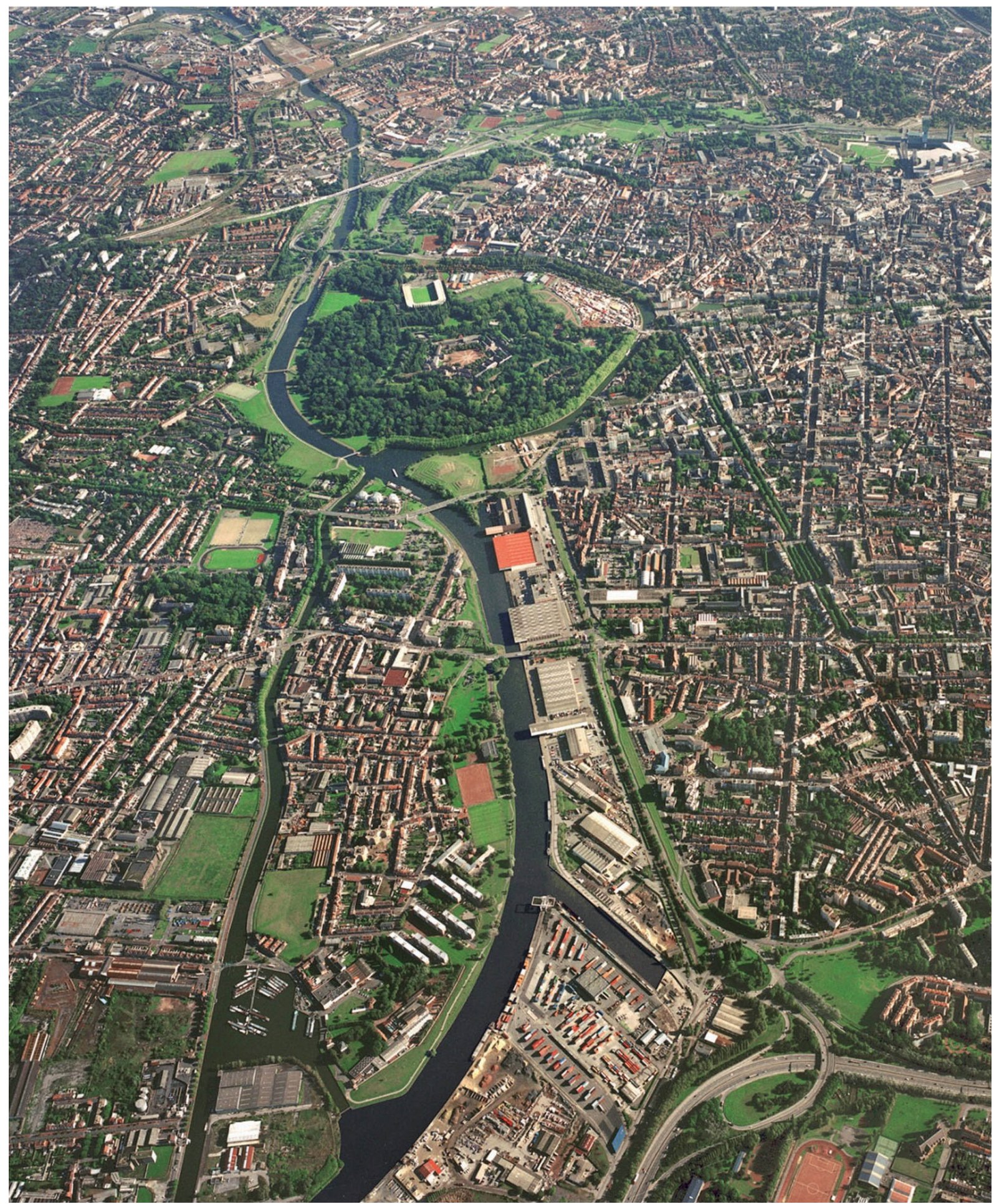




\section{A estratégia de Lille relativamente à valorização urbana da água}

Em Lille, as transformações urbanas vão intensificar-se com mais de 3000 novos habitantes à beira de água até 2016. A via de água torna-se de facto um elemento central da requalificação urbana e do retorno da cidade ao seu rio. Numerosos projetos urbanos desfilam assim no fio da água.

Estas mutações podem trazer atividade, atratividade, melhorando o quadro de vida dos habitantes e logo a imagem, a irradiação de Lille e da sua metrópole graças à água. Estas mudanças devem ser pensadas, enquadradas, daí a necessidade do Esquema diretor das águas de Lille (S.D.E.L. - Schéma directeur des eaux de Lille).

O SDEL tem um objetivo claro: proteger, economizar e valorizar a água, todas as águas, quer elas sejam potáveis, usadas, pluviais, de superfície ou ainda subterrâneas. Obra de referência para a água em Lille e na sua metrópole, este guia prático estabelece o ponto da situação em que se encontra o recurso, elabora a lista das potencialidades e propõe projetos. Faz igualmente o inventário dos atores incontornáveis, para saber quem faz o quê pela água no nosso território.

O SDEL é um documento mas constitui sobretudo a materialização de uma diligência municipal piloto que apreende pela primeira vez a água no conjunto do seu ciclo e no território de Lille - com uma visão metropolitana - a fim de conduzir uma ação coerente.

Por isso, este guia apresenta abordagens históricas, socioeconómicas e ambientais da água, sem esquecer a sua governação. Este documento convida a mudar a perceção que temos da água e a modificar as nossas práticas, os nossos comportamentos, porque a água é um assunto que a todos diz respeito.

Para responder a estes objetivos, a câmara de Lille rodeou-se de uma equipa constituída por especialistas em todos os domínios em causa (história, urbanismo, arquitetura, hidrologia, hidrogeologia, ecologia, sociologia, navegação e desenvolvimento da via de água), a fim de realizar um diagnóstico e de formular propostas de ação pluridisciplinares.

As diligências do SDEL e do projeto europeu EPAT "Água como património" fecundaram-se mutuamente, permitindo-nos ter uma reflexão que vai do local ao global. 


\section{História}

No passado, a relação mantida entre o Homem e a água foi sempre ambivalente. Inicia-se na simbiose, passando pela utilização e a seguir pela domesticação para acabar com o seu desaparecimento e destruição. Assim, os habitantes de Lille souberam desenvolver-se graças ao rio Deûle, por vezes às suas custas. Hoje, muitos procuram reencontrar essas raízes aquáticas, (nomeadamente através do patrimínio urbano).

\section{Sociologia}

Fonte de interrogação e por vezes de receio, a água é um tema que interpela. Habitantes e utentes procuram hoje uma nova relação com a água. Querem conhecê-la melhor, a fim de meIhor a desfrutar. Paralelamente, a água ocupa um lugar de destaque no ordenamento urbano, sendo um elemento de atração para as cidades.

\section{Ambiente}

A água perdura como fonte de vida e como um dos meios de aumentar a biodiversidade urbana. Este recurso aquático permanece frágil, precioso e felizmente submetido a uma atenção crescente.

\section{Economia}

A dinâmica de Lille pode ser amplificada pela atividade ligada à água ou à beira da água (empregos, alojamentos, lazer, etc.). Existe uma enorme quantidade de novas utilizações que podem vir a ser desenvolvidas, como acontece no estrangeiro.

\section{Governação}

O mundo da água é complexo e o jogo de atores envolvidos é ainda mais complexo. Este recurso sofre por vezes da multiplicidade - no entanto necessária, dada a plêiade de profissões - dos seus protagonistas. Daí a necessidade de desenclausurar as ações e de trabalhar de modo transversal.
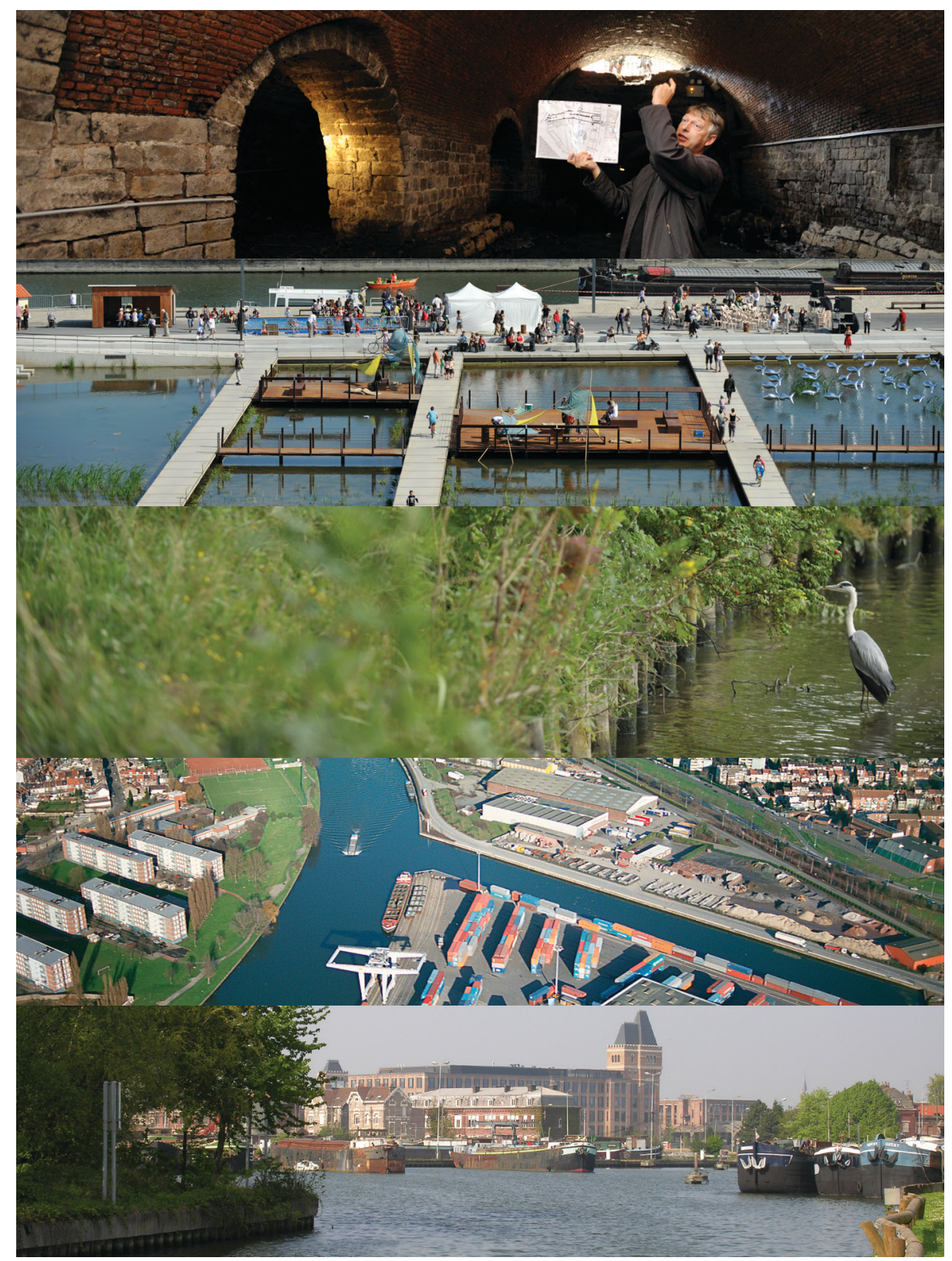

Quanto mais nos interessarmos pela água, maior será a consciência de que ela está por todo o lado. Omnipresente e por vezes cruelmente ausente, pode ser ao mesmo tempo visível e invisível, benfeitora ou perigosa, trunfo e fraqueza. É nesta perspetiva exaustiva que se inscreve o Esquema diretor das águas de Lille (SDEL), abordando a água em todos os seus aspetos. 
A água, o rio - tanto nas suas dimensões históricas como no seu devir - apresentam-se hoje como um meio evidente e eficaz para aproximar os habitantes da sua cidade e melhorar as suas condições de vida.

Lille possui com efeito um potencial inexplorado e poderia tirar mais vantagens do seu rio. É, pois, tempo de dar a palavra à água e de voltar o olhar da nossa cidade para o seu rio, movimento que é conhecido em todas as grandes metrópoles: Lille não deve deixar de entrar nesta corrente urbana.

Repensar a água na cidade significa reintegrar o conjunto destes projetos num processo coerente de valorização da água na cidade. Esquecido ou menosprezado durante muito tempo pelos seus habitantes, o Deûle dispõe agora de uma oportunidade única de se reinscrever no tecido urbano de uma maneira mais coerente.

Lille deve desde já reconciliar-se com as suas vias de água, valorizar este elemento natural no ordenamento dos seus espaços públicos e preservar este património. A noção de integração da água no ordenamento urbano precisa de uma visão global do território e de nele discernir as especificidades locais.

A relocalização do Porto Fluvial, a requalificação do Parque da Cidadela ou ainda o projeto de Coeur de la Deûle, na confluência com os braços da Basse Deûle, têm em comum a sua ligação ao canal. Numa escala mais vasta, esta porção de território lillois inscreve-se no projeto regional do Parque do Deûle, e de Trame Verte et Bleue.

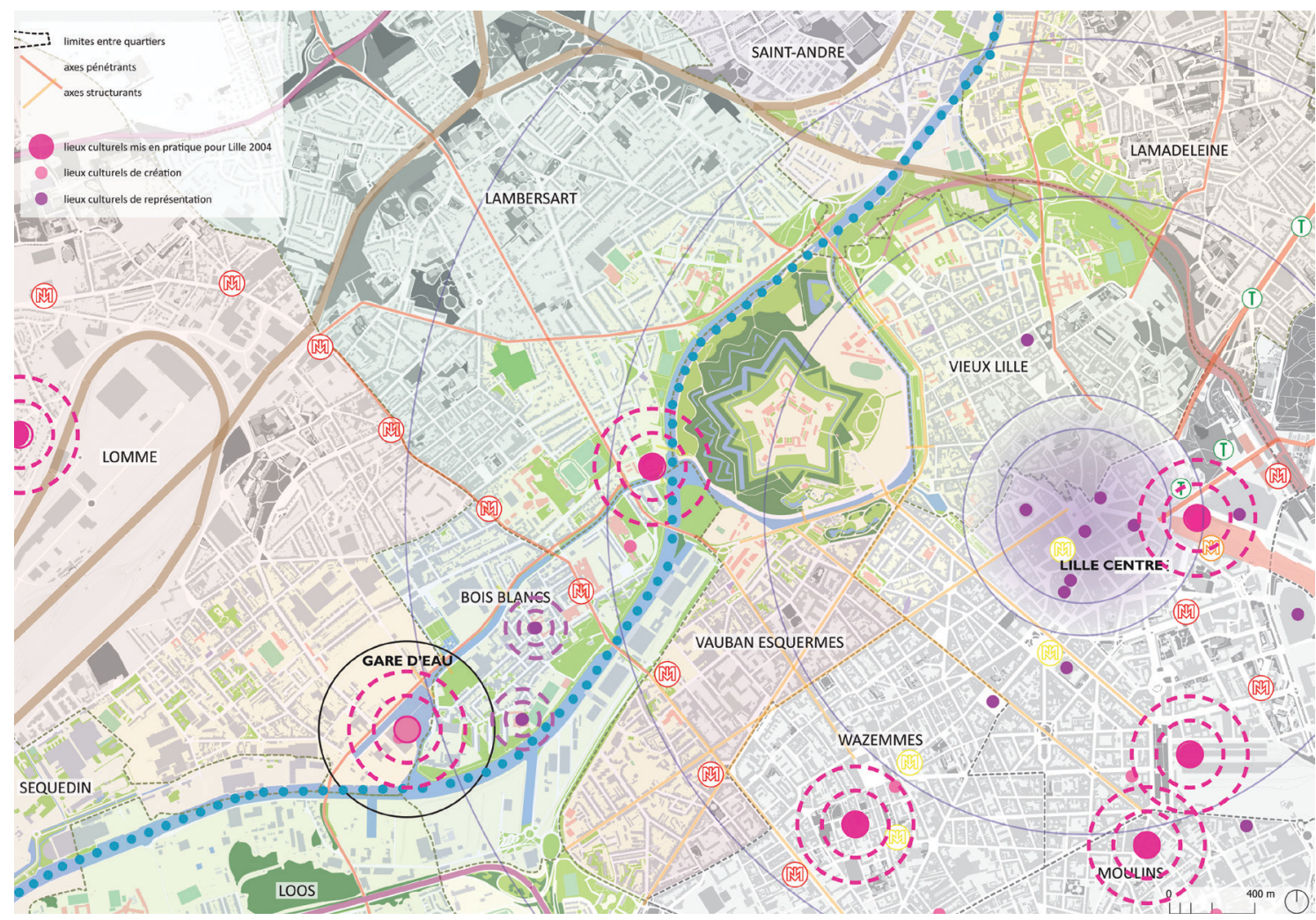

Os lugares culturais em Lille 


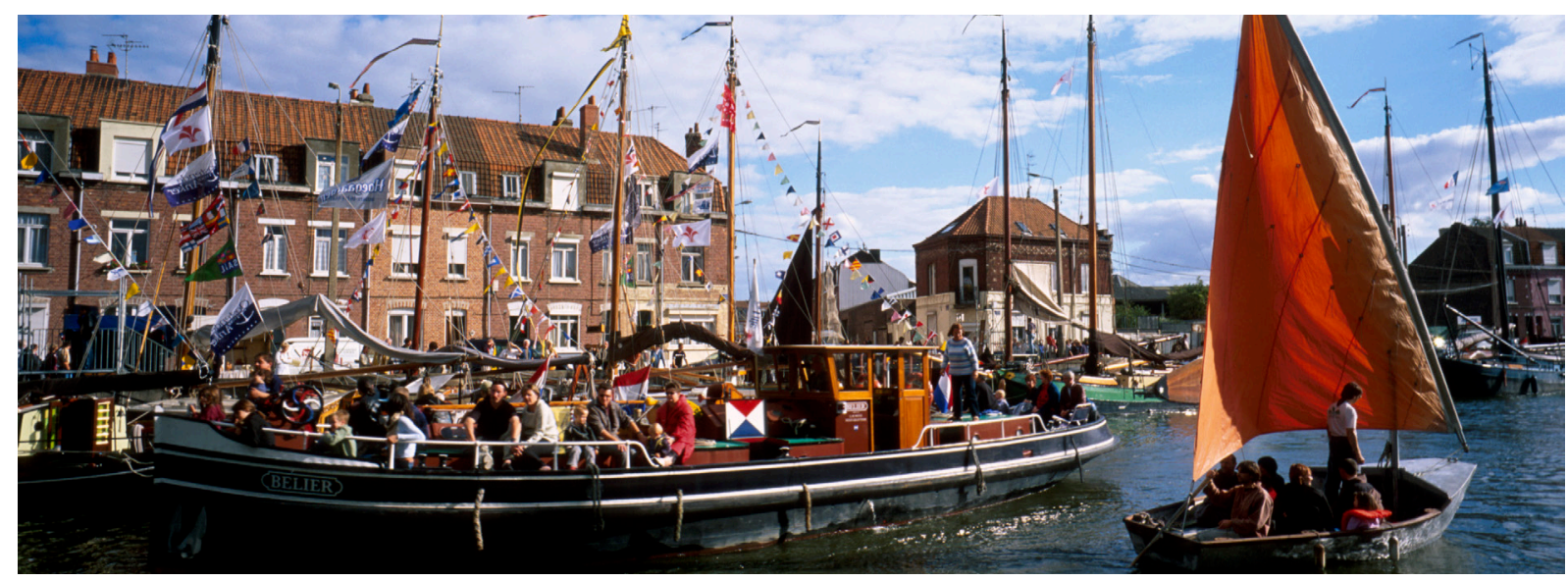

Canal de Canteleu - Bois Blancs - Jornadas do Património, 2004

Reconciliar a cidade com a água.

Hoje, o Deûle sofre de uma má imagem herdada do passado, o que não incita os habitantes de Lille a passear nas sua margens e a aventurar-se nas suas ribas. Ora, é precisamente porque as margens do rio são pouco frequentadas que a imagem do rio não muda.

O Deûle oculta um grande potencial para o desenvolvimento socioeconómico de Lille e para melhorar a sua imagem. Paralelamente, existe da parte dos habitantes uma forte procura de espaços de natureza e de animação à beira de água. Parece pois necessário agir para valorizar a via de água, o que favoreceria a reconciliação dos habitantes com o seu território.

A câmara de Lille empreendeu pois uma reconquista do Deûle com projetos urbanos de envergadura, mas estes poderiam ser mais fácil e rapidamente apropriados pelos seus habitantes se fossem acompanhados de animação, de acontecimentos culturais com vista à descoberta dos lugares.

\section{O papel da água na cultura e na animação de Lille}

\section{A cultura em geral em Lille}

Os desafios da política cultural de Lille são múltiplos mas têm o seu eixo central especificamente na criação, formação e sobretudo na acessibilidade do conjunto das populações, sem distinções sociais, à cultura. Esta vontade traduz-se na criação de um certo número de equipamentos e de acontecimentos.

A tónica recai igualmente na conservação e animação do património e no desenvolvimento da formação artística. Em última análise, a política cultural da cidade de Lille organiza-se em função de três grandes eixos: 
- Apoiar os artistas e a criação;

- Incrementar o acesso de todos os públicos à cultura e desenvolver a formação artística para os mais jovens;

- Fazer de Lille uma cidade de arte e inovação.

\section{Um rio Deûle pouco festivo em Lille}

As margens do Deûle formam uma continuidade verde e pedestre propícia às atividades desportivas e de relaxamento. No futuro, poderiam acolher acontecimentos culturais, concentrações populares.

Hoje, embora Lille tenha um índice de acontecimentos culturais de excelência (nomeadamente com Lille3000), poucos são os acontecimentos ligados à água, e não houve nenhum acontecimento de importância maior a celebrar o rio Deûle. Paralelamente, existe uma procura crescente de animações à beira de água por parte dos habitantes.

Apesar de existirem poucas animações em volta da água em Lille, o mesmo não acontece à escala metropolitana. Ainda existe um certo número de festividades, nomeadamente "a corrida à água", festa transfronteiriça, o festival "Deûle em festa", em algumas cidades desde Deûlémont até Lambersart fazemos notar que Lille não participa nessas festividades. Noutros lugares, as festas de "Saint-Vincent d'Automne" em Marcq em Barouel são também a ocasião de animação ao longo do rio Marque, bem como BlueDays sobre o canal de Roubaix. A acrescentar ainda as festas "guinguette" 4 e as praias estivais como acontece em Tourcoing ou Lambersart.

Existe em Lille um número significativo de associações e de iniciativas cidadãs relacionadas com a água e que propõem animações, acontecimentos culturais sobre a água, descobertas do rio, etc. Convém portanto não desperdiçar a riqueza própria deste terreno associativo como ponto de apoio. Paralelamente, existe uma crescente procura de animações à beira de água por parte das populações.

\section{O turismo fluvial, um manancial económico e de marketing subaproveitado}

Lille é uma cidade que dispõe de um potencial turístico real. Dois elementos culturais locais figuram no top 50 dos lugares de encontro mais visitados de França: a feira de liquidação dos comerciantes de Lille $\left(25^{\circ}\right)$; Parque Zoológico de Lille $\left(36^{\circ}\right)$. Por outro lado, Lille é uma das cidades mais visitadas de França, classificando-se em $184^{\circ}$ lugar a nível mundial de acordo com a agência Euromonitor. Este potencial continua no entanto ainda por explorar, sobretudo em termos de turismo fluvial. A proximidade

4 O termo guinguette designava, originalmente, pequenos estabelecimentos, do tipo do cabaret, instalados nas margens do Sena onde os populares se reuniam aos domingos para beber, petiscar, dançar e divertir-se à beira de água, praticando diversas atividades: regatas, canoagem, natação, etc.... 
de Lille relativamente à Bélgica e à Europa do Norte navegável oferece contudo saídas de mercado bem reais. Lille poderia tornar-se um destino privilegiado, uma etapa entre o norte da Europa e Paris.

Atualmente, 500 a 600 barcos turísticos transitam por ano na zona de Lille. Mas menos de 1 em 5 faz escala na cidade. Em causa está a ausência de paragens e de instalações que permitam a atracagem dos barcos.

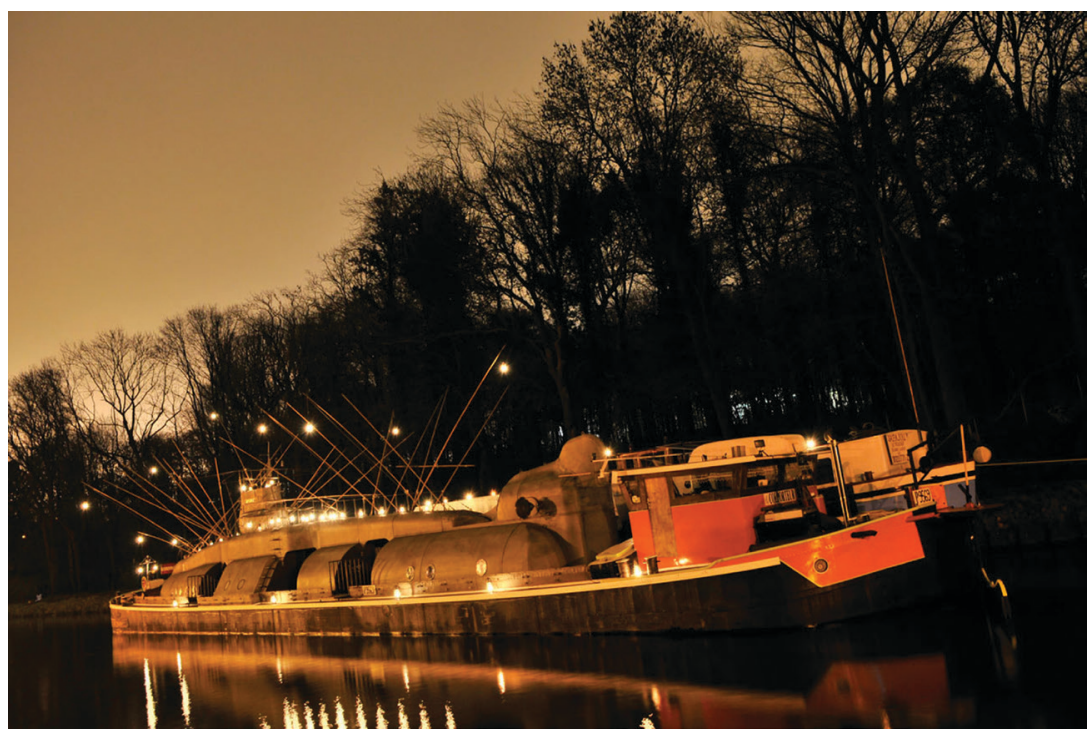

O Axolotl de Transporte Cultural Fluvial

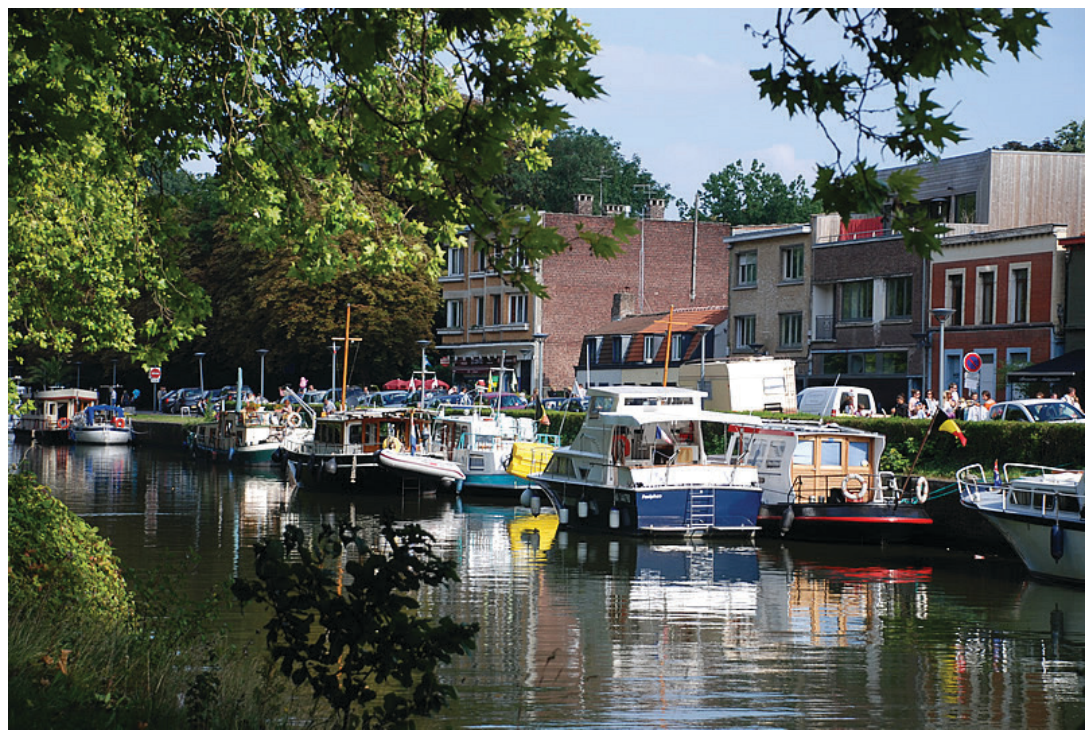

La Bras de la Barre - lugar de paragem para barcos de recreio em Lille 


\section{Do questionamento à problemática}

Lille nasceu da água, desenvolveu-se graças ao seu rio. Com o tempo foi-se estabelecendo uma relação entre o Homem, a água e a cidade. Antes de ser industrial, a água foi primeiro mercadora, depois militar. E agora? Que valores detém hoje e vai ter amanhã? Água como ambiente? Água como património? Água como cultura? Fica a interrogação.

\section{questionamento}

No início do seminário, havia um tema para Lille: A água como suporte de acontecimentos culturais. A nossa reflexão avançou, evoluiu. Transformámos assim o tema em problemática.

Como estabelecer a dimensão cultural do rio Deûle para fazer dele um espaço mais utilizado e mais vivo? Que lugar para a cultura nesta nova relação de Lille com a água?

Será que Lille quer realizar acontecimentos sobre a água e por consequência escolhe os lugares em função das suas necessidades?

Trata-se de uma ação por objetivos: Transpõe-se um acontecimento para a água.

Ou será que a água é um terreno, um meio identificado que permite levar a cabo acontecimentos que vão adaptar-se ao lugar?

Trata-se de uma ação por potenciais: Fazer com a água. Dois modos de agir diferentes para um mesmo resultado. Duas formas de fazer

\section{Do questionamento à problemática}

Convém privilegiar a abordagem por potenciais ao mesmo tempo que se definem objetivos claros. No entanto, estes devem adaptar-se aos potenciais do lugar.

Parece interessante privilegiar a abordagem cultural em vez da abordagem patrimonial.

Património = o que se passou = uma base/ uma herança

Cultura = dar vida a essa herança ao mesmo tempo que é enriquecida = Património de amanhã

\section{A problemática da cidade de Lille:}

Como estabelecer a dimensão cultural do rio Deûle para fazer dele um espaço mais utilizado, mais vivo? 


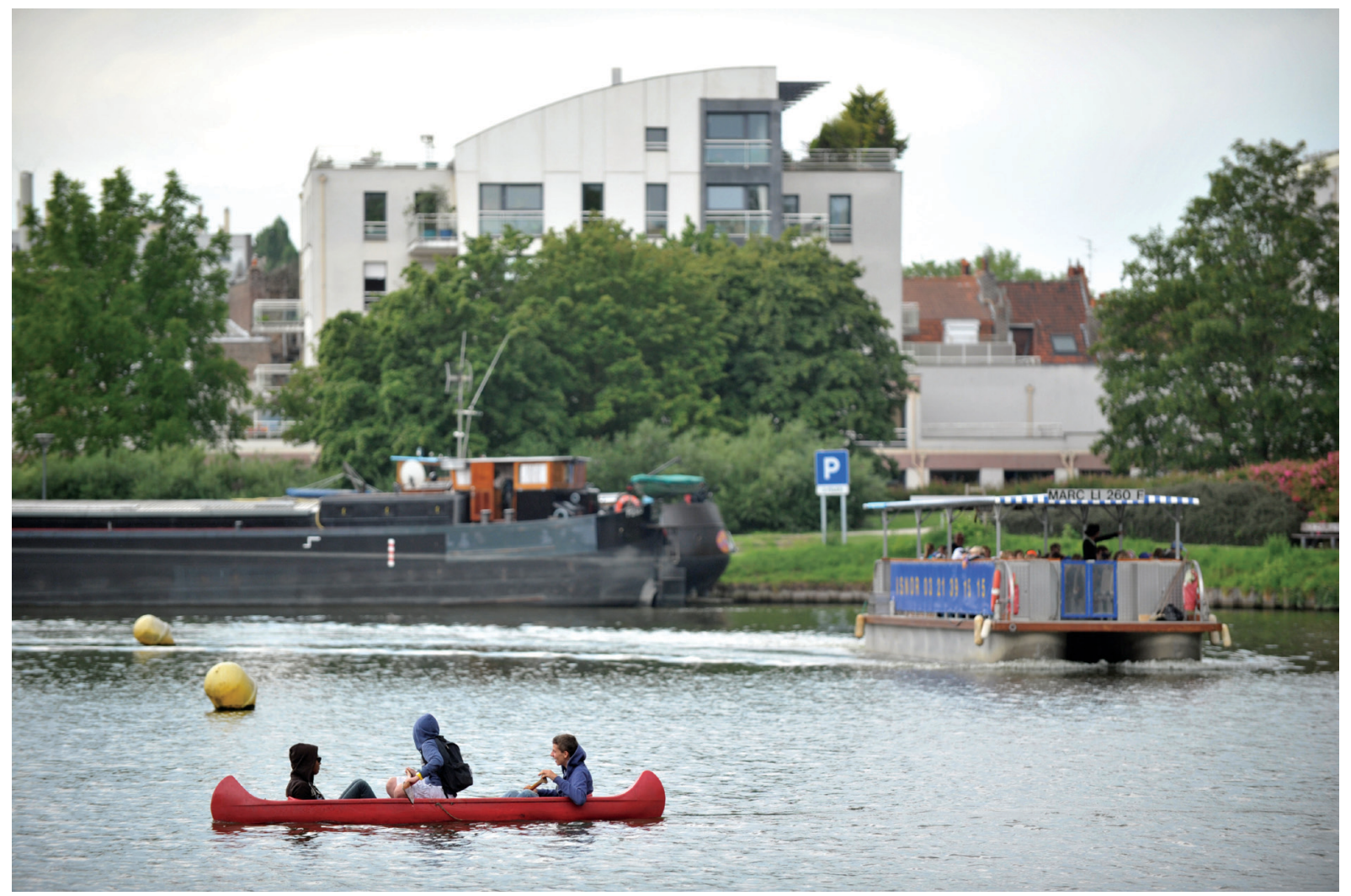

Utilização do rio Deûle 
PROJETOS 


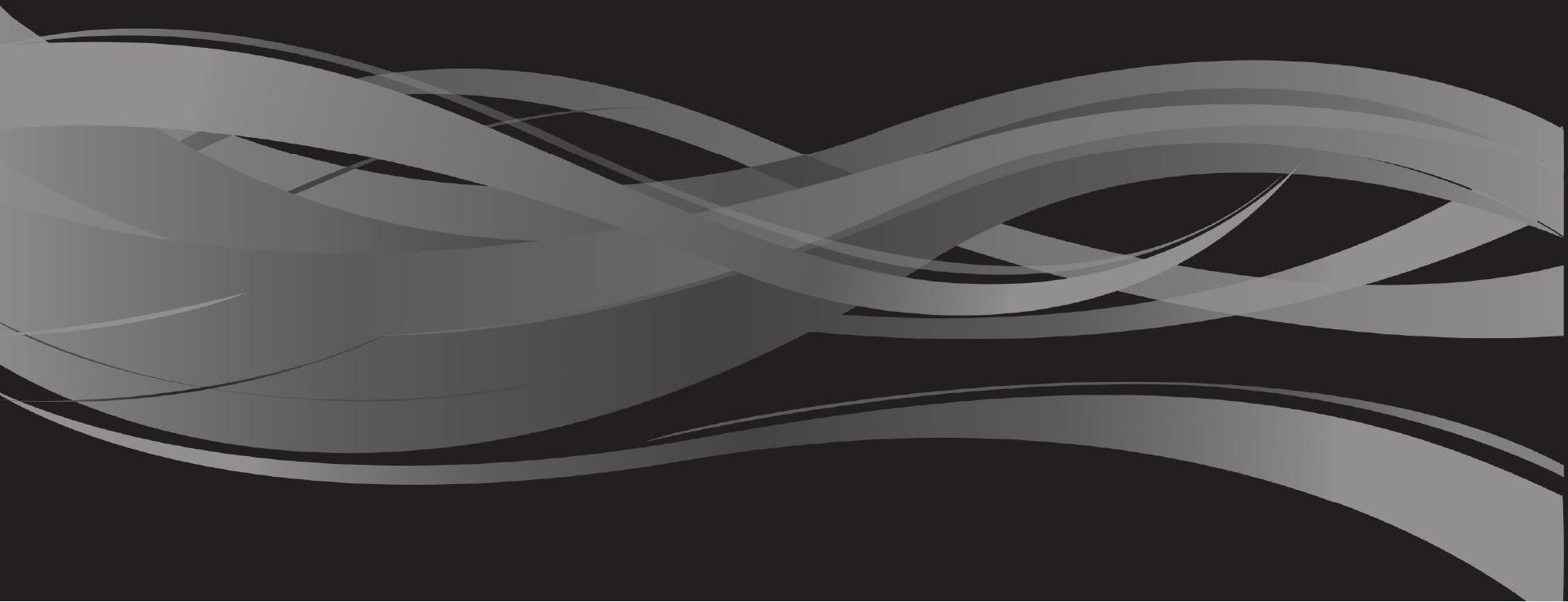




\section{INTRODUÇÃO}

ROMEO FARINELLA 


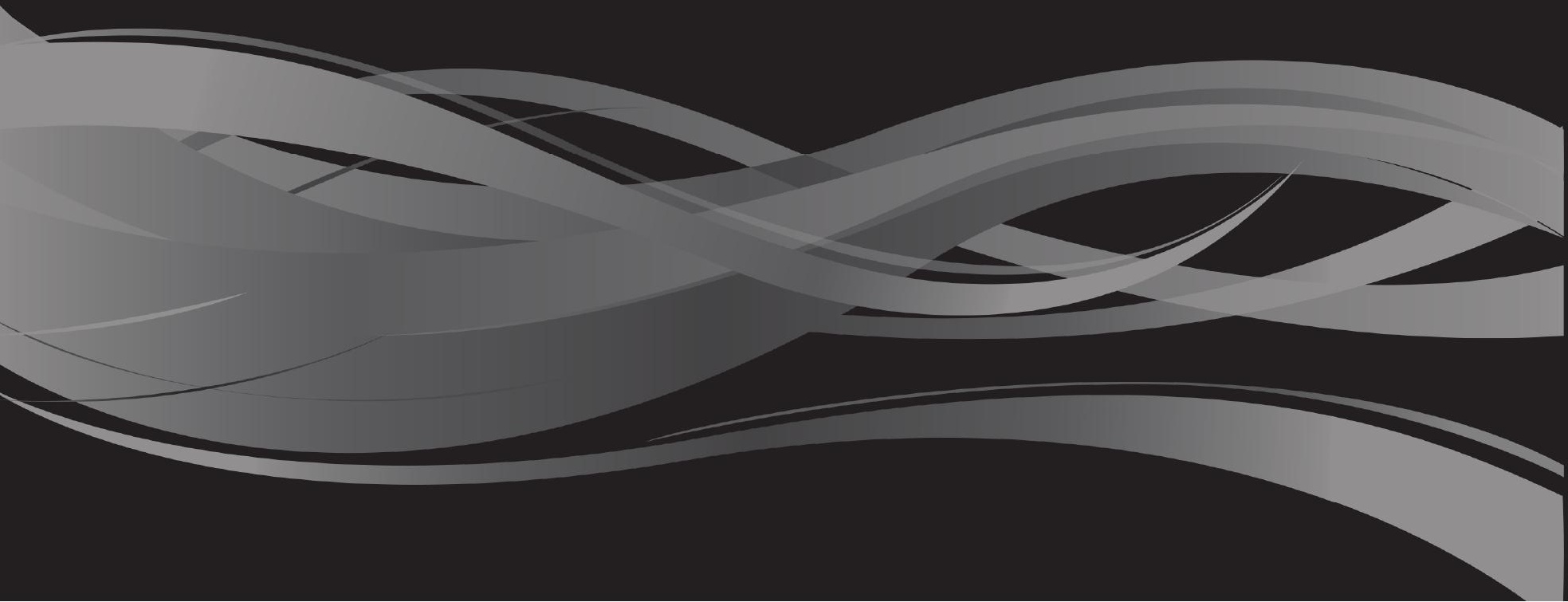




\section{REFLEXÕES SOBRE A EXPERIÊNCIA DE ATELIÊS DE PROJETO}

Os estudos de caso e os projetos apresentados neste volume representam o êxito de dois anos de trabalho, em que quatro grupos de pesquisa trabalharam em contacto próximo com o território e com as instituições. Os êxitos deste trabalho são apresentados nos capítulos seguintes. As problemáticas da água como factor de identificação local de um território foram objeto, há alguns anos atrás, de um outro projeto europeu denominado "os rios como infra-estrutura cultural". Nessa ocasião, o interesse dos grupos de trabalho foi orientado no sentido de reconstruir a importância do rio na história de algumas cidades e de algumas paisagens europeias, aprofundando a questão da importância da história e da cultura associadas à paisagem fluvial nas estratégias de planificação.

O objeto de trabalho deste livro representa, de certo modo, a evolução dessa experiência, mas o interesse concentrou-se nas problemáticas da relação entre cidade e água na definição de projetos de regeneração urbana, concebidos como fatores estruturais de uma nova visão urbana. O terreno de experiência do projeto, que serviu para aprofundar os vários estudos de caso, deriva da partilha de problemáticas que, desde há algumas épocas para cá, caracteriza a ação de numerosas cidades ativas na reabilitação dos seus espaços fluviais; em particular, esses estudos de caso foram aprofundados à luz de algumas preocupações:

1. A primeira preocupação teve em conta a valorização da eficácia das políticas de salvaguarda, de tutela e de requalificação das zonas urbanas históricas ligadas à presença da água. Locais que marcaram fortemente a identidade das cidades estudadas, como por exemplo, os cais e os espaços portuários, os espaços naturais ou rurais ainda existentes e, por fim, as zonas abandonadas (industriais e infra-estruturais) deslocadas ao longo dos troços urbanos dos rios;

2. Um segundo tema de reflexão incidiu sobre as possibilidades concretas de conceber espaços urbano-fluviais regenerados como componentes e elementos de um sistema de relações urbanas e territoriais mais amplo, de modo a haver uma ligação das diversas partes de uma área urbana atravessada por um curso de água. O objetivo é contribuir para a construção de corredores ecológicos e estruturas verdes para estabelecer e consolidar novas relações entre as cidades e a natureza e entre as zonas urbanas e as rurais, presentes dentro de um aglomerado urbano ou metropolitano.

3. Por fim, na definição dos objetivos da regeneração urbana, os vários grupos de trabalho interrogaram-se sobre a utilização social dos espaços fluviais. Ao longo do tempo, o rio nas cidades foi usado como espaço doméstico, de trabalho e de lazer. As alterações provocadas pela evolução dos modos de viver e usar a cidade e os cursos de água estão, por um lado, ligados à melhoria das condições de vida dos espaços domésticos e dos locais de trabalho e, por outro, ligados ao agravamento das condições ambientais e ecológicas dos cursos de água. A poluição das águas, assim como a sua transformação em espaços de serviço para as atividades industriais 
ou para o aumento das infra-estruturas, originou um distanciamento das pessoas dos espaços anteriormente usados quotidianamente. Nas últimas décadas, a redefinição dos espaços do rio e as políticas ambientais originaram um fenómeno de reutilização e de renovada identificação por parte dos cidadãos para com estes espaços, levando a modalidades formais e informais de utilização e, portanto, a uma revalorização social destas zonas urbanas.

A estas finalidades gerais associaram-se objetivos mais específicos, não verificáveis em muitos documentos estratégicos e de planificação urbana que promoveram a regeneração e a valorização das paisagens urbanas de água. O aprofundamento das hipóteses de projeto, respeitante aos vários estudos de caso abordados neste trabalho, estabeleceu os seguintes objetivos específicos:

- contribuir para a redescoberta da importância dos cursos de água e das paisagens de água nas estratégias de reabilitação urbana e paisagística das cidades europeias, atuando em cidades e situações específicas com o objetivo de gerar reflexões e procedimentos que poderão ser generalizados;

- aprofundar os aspetos de projeto das políticas urbanas e paisagísticas dos países envolvidos e as práticas associadas às experiências de projeto urbano ligadas às especificidades das cidades de água;

- valorizar e difundir as componentes culturais e naturais relacionadas com os cursos de água e, em particular, a relação entre a água e os espaços urbanos;

- incentivar a comparação entre as diversas tradições, competências e métodos nas políticas que visam a conservação e a reabilitação das cidades de água, através de um confronto de experiências e uma experiência de projeto tendo em conta os diversos estudos de caso e as diversas abordagens propostas pelos grupos de pesquisa;

- contribuir para a difusão de uma cultura de paisagem através de atividades dedicadas às coletividades territoriais e incentivar processos de identificação das comunidades locais com o território, tendo em conta as recomendações da Convenção Europeia da Paisagem.

As atividades culturais propostas no âmbito do projeto "Água como património" defrontaram-se, portanto, com o tema mais geral da regeneração das paisagens de água nas cidades fluviais. Durante os dois anos de projeto, o trabalho foi conduzido no interior de laboratórios de projeto denominados AteLP - Ateliês locais de projeto - e previu as seguintes ações:

- sistematização dos conhecimentos atuais sobre o tema da regeneração urbana das cidades fluviais;

- organização dos ateliês de projeto que trabalharam nos estudos de caso das cidades envolvidas no projeto e o acordo com as autoridades locais, utilizando processos participativos;

- elaboração de sugestões de projeto para propor às coletividades territoriais envolvidas. 


\section{Os estudos de caso}

O tema geral dos ateliês é marcado pelo seguinte título: Reabilitação e revalorização das paisagens fluviais urbanas. Este tema geral foi redefinido segundo uma chave de leitura mais específica, adaptada às problemáticas locais. Por isso, os quatro grupos de trabalho atuaram simultaneamente nas cidades envolvidas no projeto, encontrando-se em seminários para partilharem experiências e fazerem o ponto de situação do trabalho. As cidades laboratório foram as seguintes: Braila, Coimbra, Comacchio e Lille. Nos capítulos seguintes, será fornecido um enquadramento e uma leitura das dinâmicas destas cidades, seguido de uma apresentação dos projetos. Por agora, limitamo-nos à descrição sintetizada dos tempos pré-escolhidos, acompanhada de uma breve descrição do carácter urbano de cada cidade.

Os quatro temas específicos escolhidos foram os seguintes:

Braila: repensar as relações urbanas e paisagísticas entre a cidade e as suas áreas portuárias encerradas ou subutilizadas.

Coimbra: O tema da água como oportunidade para construir um espaço "verde" e "azul", de modo a requalificar os espaços do rio e as relações com a cidade;

Comacchio: o papel do património natural e urbano na redefinição do sistema urbano que liga a cidade lagunar à cidade situada junto à costa, trabalhando na reintrodução da água como "material" para a regeneração urbana;

Lille: o tema das potencialidades dos espaços de água existentes incluídos no projeto como suporte para a organização de grandes eventos culturais.

A cidade de Braila (220.000 habitantes) está situada no sudeste da Roménia, ao longo do percurso interno do Danúbio. A cidade é a capital do homónimo departamento e está próxima de uma outra cidade portuária, Galati (também erguida nas margens do Danúbio), com a qual decidiu formar uma grande zona metropolitana. As duas cidades tiveram uma história paralela. Durante vários séculos, serviram de porta de acesso ao Mar Negro a dois principados romenos: Galati para a Moldávia e Braila para a Valáquia. Todavia, esta última teve um papel mais importante ao longo da história em virtude de estar localizada ao longo de uma importante estrada comercial. Braila é a cidade portuária mais importante situada ao longo do antigo percurso romano do Danúbio, dos Cárpatos até ao delta. A cidade faz parte de uma rede histórica de cidades que foram, a partir de 1830, objeto de intervenções, modernizações e reconstruções geradas por um novo plano urbano geral. Durante mais de um século, estas cidades conheceram uma relevante riqueza graças à exportação de cereais. A prosperidade económica teve também importantes repercussões na qualidade da arquitetura e hoje apresenta um património urbano, monumental e industrial relevante, mas que se encontra num preocupante estado de degradação, acentuado pela crise económica e produtiva que a cidade enfrenta. A propósito da relação entre cidade e rio, um dos aspetos problemáticos, presente também em todas as cidades portuárias do rio Danúbio, é a ausência de uma verdadeira preocupação pelas formas de articulação da relação 
entre cidade e rio. Portanto, o objetivo principal do AteLP foi identificar uma estratégia de ações de projeto capazes de recompor a relação entre o espaço da "falésia", onde cresceu a cidade histórica, o espaço do rio e o porto industrial, com os seus edifícios de interesse testemunhal e patrimonial.

Coimbra é uma das mais importantes cidades históricas de Portugal. Com os seus 157.000 habitantes, situa-se no centro do país e é atravessada pelo rio Mondego. É a cidade universitária mais antiga de Portugal, com o seu monumental centro histórico composto por ruas estreitas, praças, escadarias e arcos medievais. Coimbra teve já um grande projeto de requalificação da zona urbana do Mondego através do Programa "Polis", o qual contemplou uma área de 80 hectares. Trata-se de um programa de financiamento nacional que visa o desenvolvimento de projetos de requalificação urbana. Em particular, a cidade foi alvo de intervenções de projetos de requalificação dos espaços ao longo das duas margens do rio. Esta ampla porção da cidade já foi objeto de projetos de arquitectos e engenheiros de relevância nacional e internacional, assim como de professores do Departamento de Arquitetura da Universidade de Coimbra. Estes projetos incidiram apenas nas áreas situadas nas proximidades do rio e não aprofundaram as relações com as áreas do centro da cidade, por isso o interesse principal do AteLP foi a definição de um esquema de orientação para o conjunto das áreas urbanas do rio com o estudo de projetos que visam melhorar as relações entre o curso de água e a cidade.

Comacchio é uma cidade com cerca de 20.000 habitantes que durante o período turístico estival supera os 200.000 habitantes. A cidade cresceu num território lagunar, desenvolvendo-se sobre algumas ilhas e, hoje, é a sede do Parque regional do Delta do Pó, dentro de um território classificado pela Unesco como património mundial. A complexidade deste território, originada pela histórica predominância da água, foi em grande parte transformada pelos trabalhos de recuperação que, durante o decurso do século XX, foram levados a cabo numa grande parte das lagoas do litoral do município de Ferrara. O centro histórico da cidade apresenta, portanto, uma morfologia urbana particular, condicionada por este particular contexto paisagístico e pela estreita relação entre as águas dos vales e dos canais. A partir da segunda metade do século XX, desenvolveu-se ao longo do litoral um complexo turístico costeiro dos mais importantes da região Emilia-Romagna, que apresenta hoje vários problemas de requalificação urbana.

Além do turismo balnear e ambiental, a economia do território é caracterizada também pelo setor das pescas, concentrado na localidade de Porto Garibaldi. A complexidade ambiental, histórica e económica deste território representa uma potencialidade estratégica, mas é, ao mesmo tempo, um ponto de fraqueza devido às dificuldades em ativar políticas de desenvolvimento local que tenham em conta todos estes aspetos.

Com os seus 226.000 habitantes, a cidade de Lille, em conjunto com os seus municípios associados, Hellemmes e Lomme, constitui a maior cidade do norte da França. Centro de um aglomerado de 87 municípios, Lille, junto com alguns municípios da vizinha Bélgica, dá vida a uma metrópole transfronteiriça de 1.9 milhões de habitantes situada no centro da região euro.

Esta situação geográfica privilegiada, valorizada por uma rede fluvial e de transportes terrestres muito densa, faz de Lille uma porta de entrada para a Europa do Norte. 
Hoje, a cidade, em virtude da sua posição e história, atrai um número cada vez maior de turistas, o que contribui para a sua notoriedade. Erguida dentro de um meandro do rio Deûle, Lille desenvolveu-se com uma relação muito próxima com a água. Os processos de industrialização e modernização modificaram, todavia, as relações morfológicas entre a cidade e os seus cursos de água, mas deixaram um rico património urbano, arquitectónico e cultural ligado à água, que se tornou um ponto de partida para desenvolver a beleza do município e das metrópoles, assim como o quadro de vida dos habitantes.

O objetivo da atividade do AteLP é o de propor estratégias de redefinição urbana, arquitectónica e cultural dos cursos de água e das paisagens fluviais do território de Lille, como suporte de grandes eventos culturais ligados à água. Este objetivo, que tem fortes repercussões em termos de reconfiguração do ordenamento urbano, situa-se em continuidade com os eventos de Lille 2004 - Capital Europeia da cultura, e em antecipação do novo programa Lille 3000. A atividade de projeto concentrou-se, portanto, nas modalidades de transformação dos diferentes lugares da cidade histórica e do setor urbano erguido em redor dos canais.

O projeto desenvolveu-se, portanto, seguindo os rastos dos antigos canais e propôs intervenções ao longo dos cais do rio Deûle, relacionando a requalificação do espaço urbano com a valorização dos recursos naturais ainda existentes.

\section{Procedimentos}

As atividades de projeto dos AteLP foram desenvolvidas com a aplicação de processos participativos que permitiram, durante meses de trabalho, estabelecer relações contínuas com atores técnicos, culturais e sociais, o que contribuiu, de vários modos, para a especificação dos temas de projeto e o seu aprofundamento. Estes processos foram definidos e geridos pelos vários grupos nacionais, experimentando, em alguns casos, novas práticas ou, noutros casos, continuando os processos participativos e de projeto já iniciados. A este respeito, os objetivos definidos em fase de esboço do projeto foram os de contribuir para o início de uma dinâmica coletiva o mais partilhada possível, com análises, debates, negociações e compromissos, que se pode encontrar na base de qualquer processo de decisão. Os procedimentos participativos mudam também de acordo com os problemas enfrentados, por isso desenvolveram-se várias formas de participação nas experiências das últimas décadas. A natureza do nosso projeto era mais cultural do que técnica e os vários grupos trabalharam mais na construção de cenários de projeto do que na solução de problemas específicos, por isso definiram-se procedimentos participativos orientados mais para a construção dos problemas e dos objetivos de transformação, como os seguintes:

- atelier multi-atores;

- audições públicas; 
- conferências de consenso;

- grupos e fóruns de reflexão;

- ligação entre especialistas e decisores;

As atividades de projeto foram conduzidas seguindo um método multi-disciplinar que permitiu comparar as problemáticas da conservação e da valorização do património arquitetónico, urbano e paisagístico e os aspetos sobre o papel das áreas rurais e naturais ainda presentes com as problemáticas em projetar novas paisagens urbanas e novos espaços públicos. Para o trabalho das equipas contribuíram quer as universidades envolvidas, quer as estruturas técnicas presentes no território. É de ressalvar o envolvimento de doutorandos, jovens licenciados, licenciandos e alunos do ensino secundário. 


\section{BRAILA ONDE O DANÚBIO VEM À CIDADE}

NICOLAE LASCU (Coordenador)

ANDREEA MIRELA CHINA 


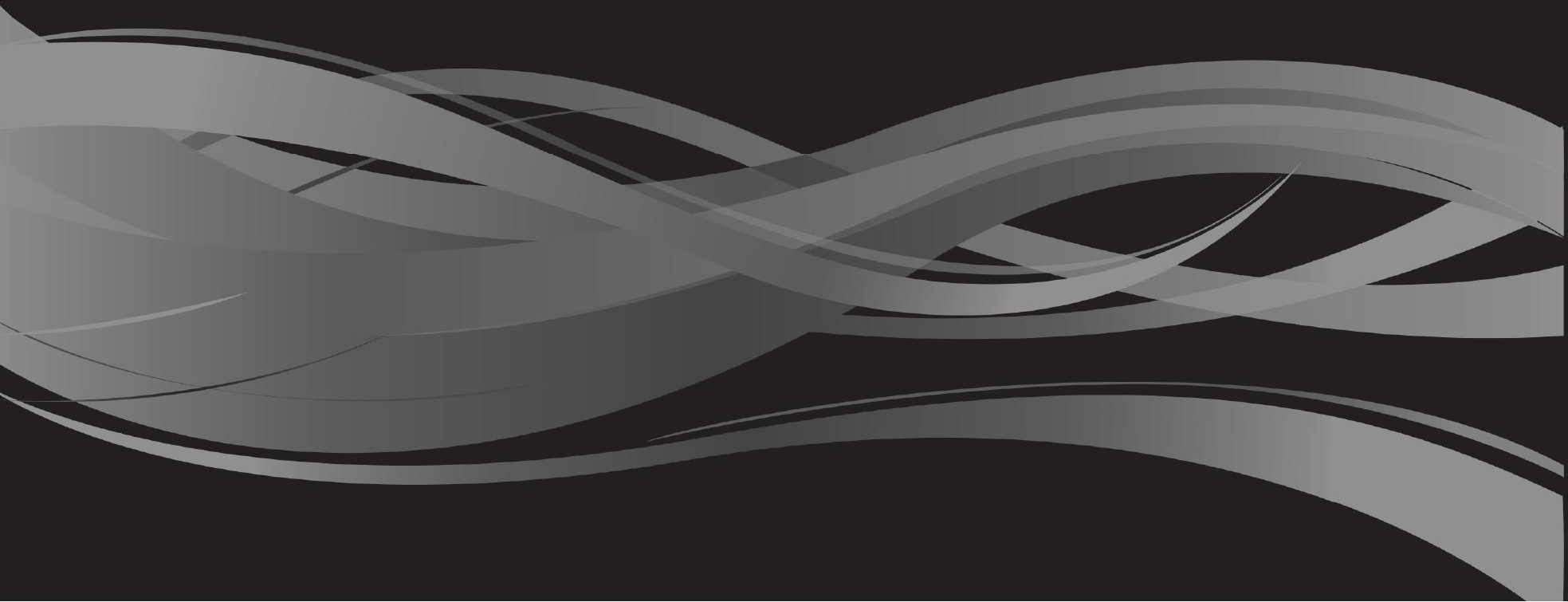




\section{O DANÚBIO E A FRENTE RIBEIRINHA DE BRAILA}

À luz das atuais tendências, que conferem ao desenvolvimento sustentável uma importância crescente, resulta claro que Braila, cidade pós-industrial com um débil desenvolvimento económico, poderá reativar o seu antigo estatuto de porto danubiano se se propuser explorar o rio enquanto via de transporte limpa e eficiente, reconvertendo e reinventando, do mesmo passo, a utilização do seu património industrial abandonado.

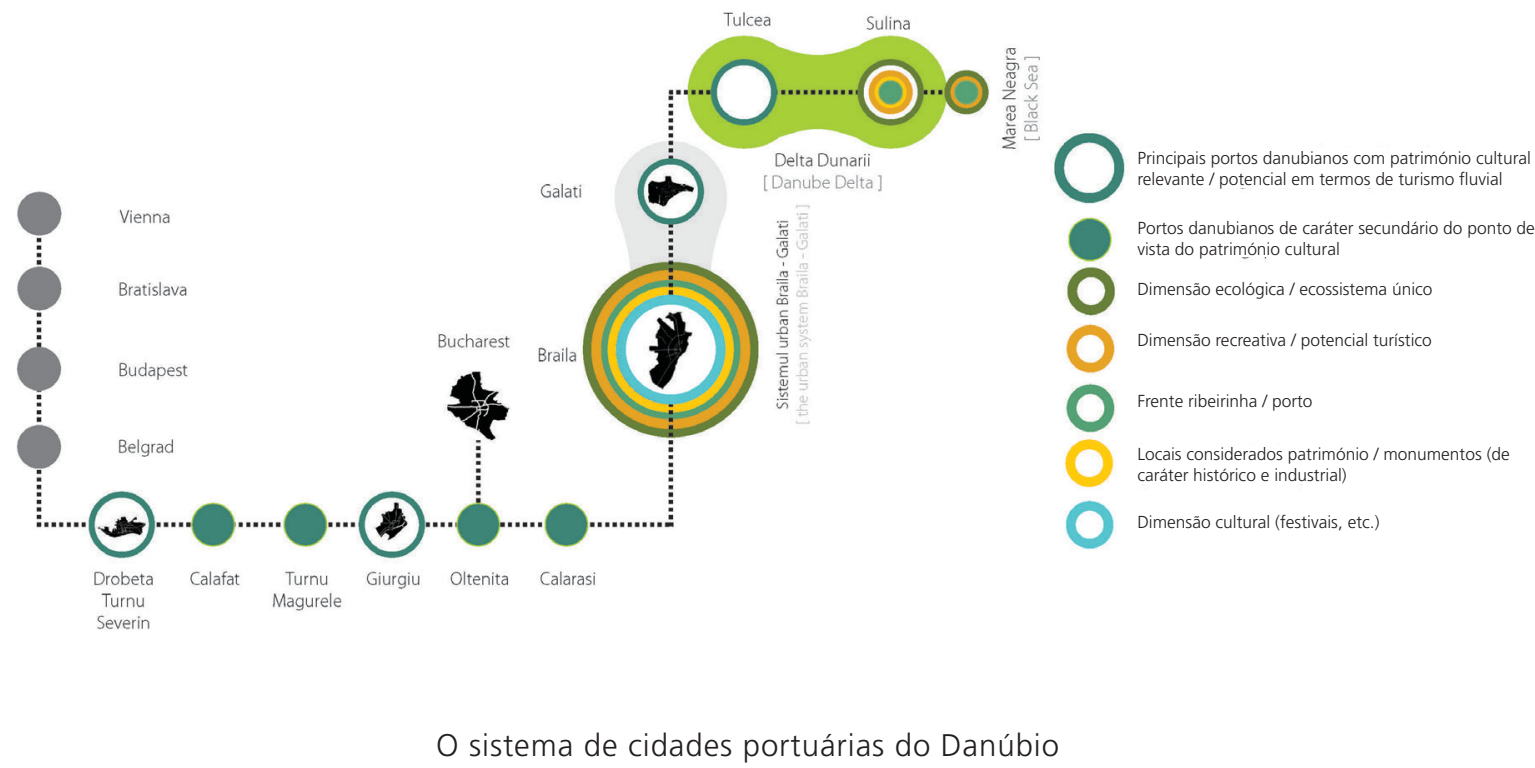

Parte integrante de um sistema de cidades portuárias situadas ao longo do Danúbio, e em posição de vir a assumir um lugar significativo a nível europeu, Braila - a exemplo das restantes cidades ribeirinhas - figura na Estratégia da União Europeia para a Região do Danúbio. A Comissão Europeia deu prioridade a 4 grandes eixos, que constituem o conteúdo central para a estratégia do Danúbio:

- Ligação da Região do Danúbio: incluindo a mobilidade, a energia sustentável, a cultura e o turismo;

- Proteção do Ambiente na Região do Danúbio: incluindo a qualidade da água, a prevenção do risco, a biodiversidade e a paisagem;

- Fomento da Prosperidade na Região do Danúbio: incluindo o conhecimento, a educação, e ainda o investimento nas pessoas e nas competências;

- Reforço da Região do Danúbio: capacidade institucional e cooperação, proteção e segurança.

Com estas iniciativas propõe-se a União Europeia desenvolver e alargar a navegação nos rios interiores, tornando assim possível, graças à Estratégia da UE para a Região do Danúbio, atraiar empresas de turismo de maneira a maximizar o potencial turístico e a fortalecer as ligações culturais. 
A posição dominante que Braila ocupa na parte romena do Danúbio tem reflexo no potencial turístico da cidade, por sua vez decorrente do património edificado, dos sítios protegidos (património tangível e intangível, extremamente rico e variado), da dimensão cultural (festivais de música como o Concurso Internacional de Canto Hariclea Darclee e outros eventos) ou da dimensão ambiental (veja-se a biodiversidade e a riqueza ecológica da llha Pequena de Braila - classificada na Rede NATURA 2000 ou da Ilha Grande de Braila, elementos que, no seu conjunto, constituem uma unidade de paisagem).

No plano do território, as vizinhas cidades portuárias de Braila e Galati começam a dar forma a um único sistema urbano, especialmente do ponto de vista administrativo. Mas uma relação ainda mais fácil de explorar será a que a cidade mantém com a Ilha Grande de Braila, que poderá funcionar caso nela seja introduzida uma vertente recreativa sob a forma de extensão funcional da cidade. Sendo este um espaço pouco utilizado, devido principalmente à falta de um acesso direto entre os dois territórios - a cidade e a ilha -, a expansão de certas áreas de lazer através da transferência de algumas atividades para a zona fronteira à cidade (como a praia, no verão, infraestruturas para a pesca no inverno, etc.) poderá revelar-se altamente eficaz.

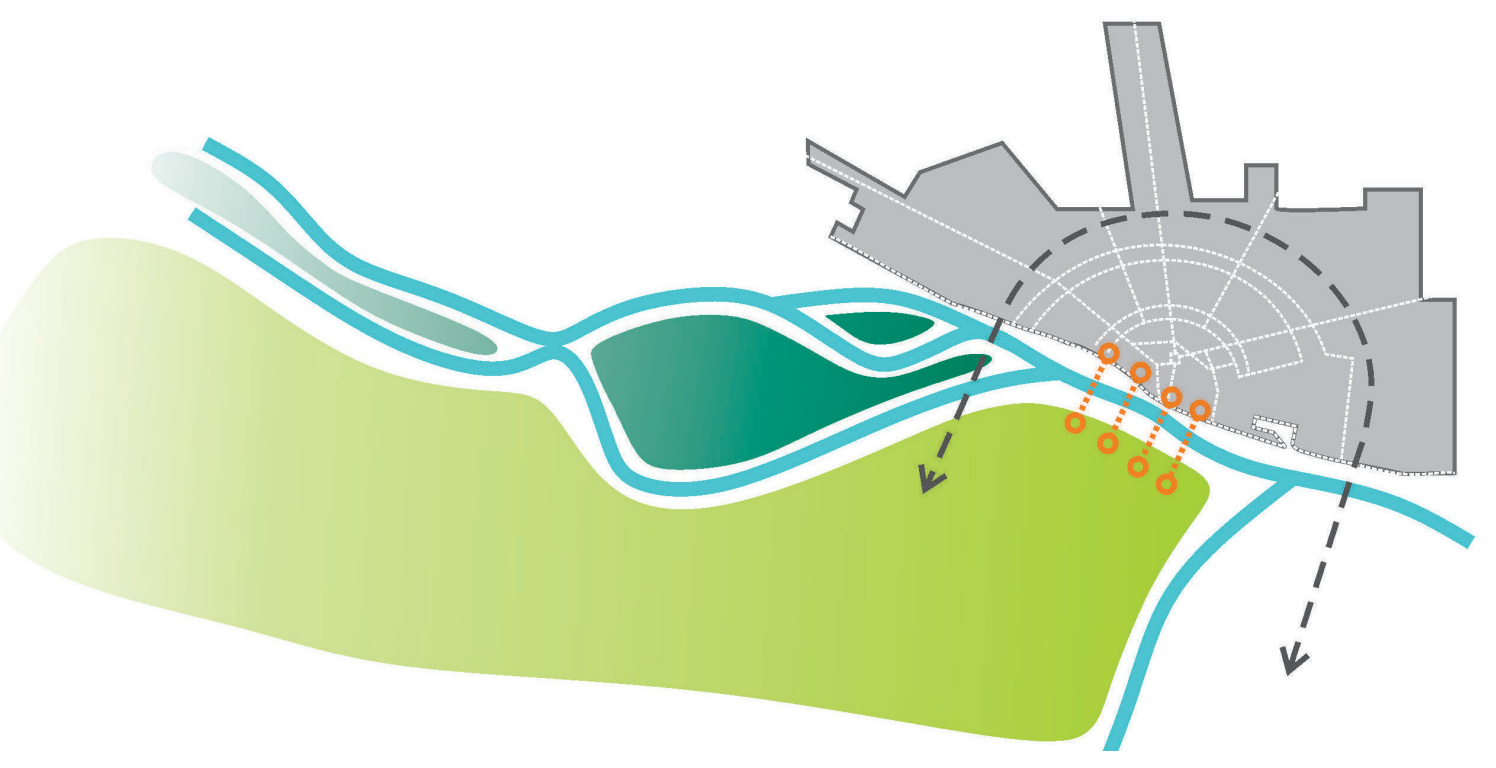

Esquema da relação de Braila com o território envolvente

Nenhuma destas propostas de estabelecimento de relações territoriais com Braila poderia ser levada a cabo sem ter em conta as formas de revitalizar o papel da frente ribeirinha na relação com a cidade. Estamos perante uma relação ambivalente, em que a água desempenha um papel funcional no nascimento e crescimento da cidade, e que não só não pode ser negada como só pode ser expressa "voltando" a cidade e respetivas atividades para o rio e integrando o rio, por sua vez, na vida e na economia da cidade.

Para a prossecução deste objetivo, as áreas de intervenção em que o projeto se centrou foram, assim, associadas diretamente à frente ribeirinha e à relação potencial entre o rio e o centro histórico. 
A área de intervenção definida pelo novo centro administrativo (situado na Avenida da Independência) e pela zona do porto (Rua Vadul Rizeriei) constitui a principal área de contacto entre o rio e a cidade, sendo aí que reside o maior potencial com vista a uma requalificação (já que possui tanto áreas não edificadas como um rico património industrial - o qual, apesar de se encontrar em avançado estado de ruína, é passível de restauro e de reutilização).

O projeto optou por dividir as áreas de intervenção de acordo com o seu perfil específico, de maneira a restaurar os laços entre as diferentes zonas da cidade e as atividades relacionadas com a água. Considerou-se que uma abordagem deste tipo poderá traduzir-se também em estratégias de longo prazo. Assim, a proposta centra-se na criação de conexões diretas entre as áreas residenciais (os principais pontos de concentração humana) e a frente ribeirinha. A proposta tem um duplo propósito: fazer a ligação norte-sul, ao longo do rio, e estabelecer conexões na direção este-oeste. Quanto ao eixo este-oeste, o problema está nos obstáculos impostos pela própria topografia (isto é, no facto de a parte mais nova da cidade se ter desenvolvido no patamar mais elevado, por oposição ao núcleo histórico e ao porto, que se foram desenvolvendo no vale do Danúbio).

Em relação à frente ribeirinha (a área de intervenção), a equipa identificou três subzonas que como tal foram definidas e sobre as quais nos debruçaremos de seguida: a Promenada, área de passeio entre o novo centro administrativo (o espaço público frente à Câmara Municipal) e a antiga Gare Fluvial; a praça da Gare Fluvial; e o Jardim Público mais a área abaixo deste espaço - dentro dos limites da zona liberta relacionada com as atividades portuárias, área que inclui também a Fábrica Lichiardopulos. Uma quarta área será a do espaço relacionado com o porto, mas considerações de ordem económica justificam que não seja aqui tratada.

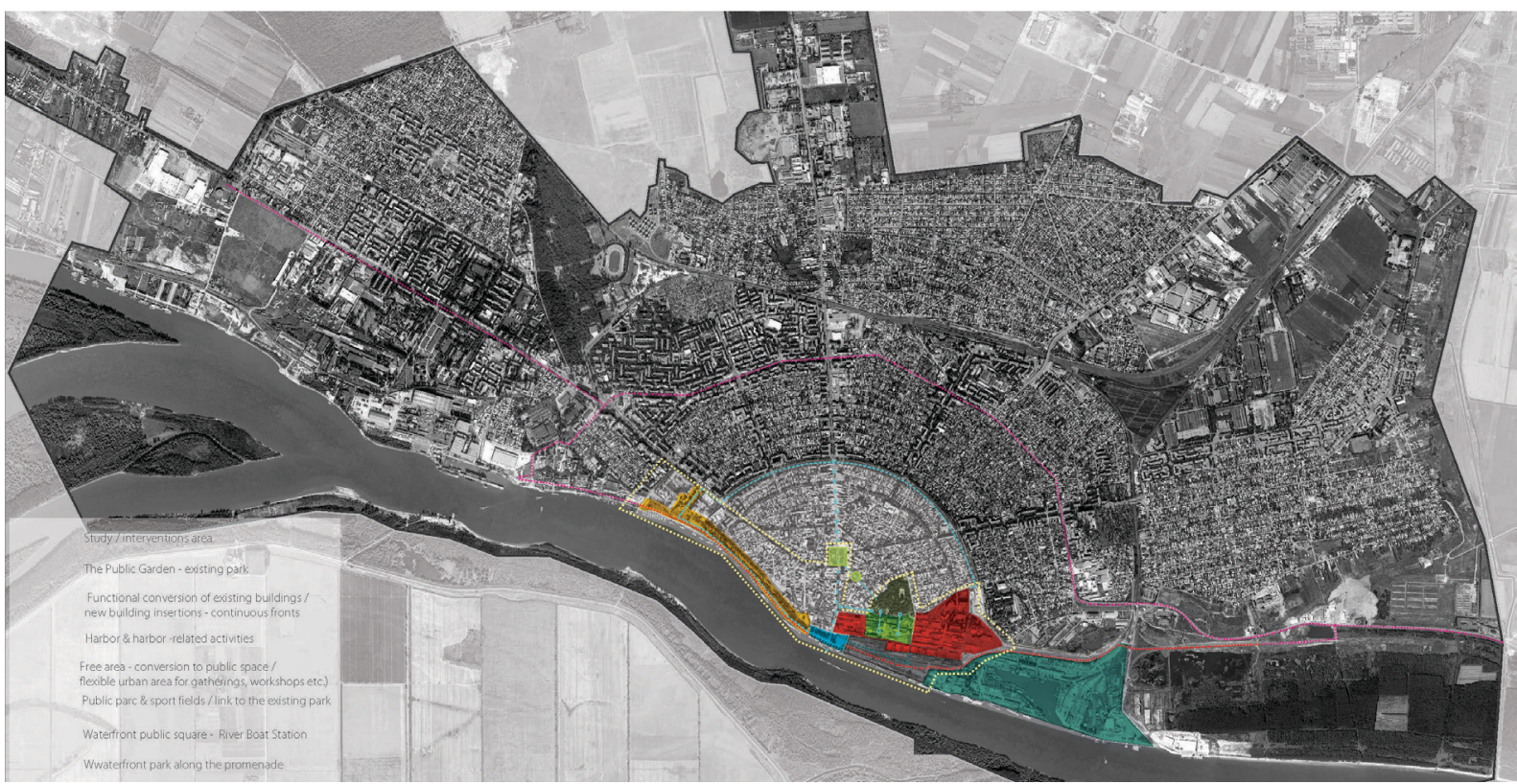

As principais áreas de intervenção do projeto 
1titin

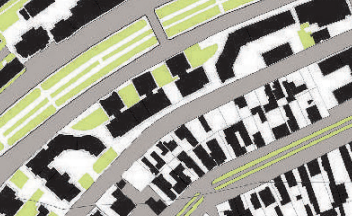

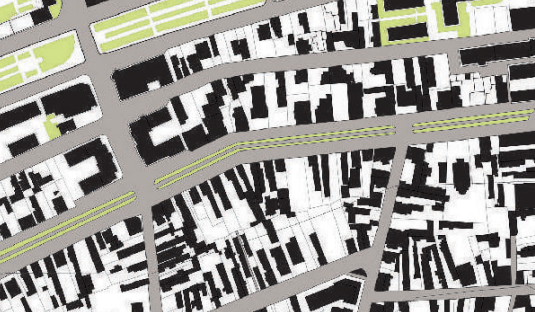

a.

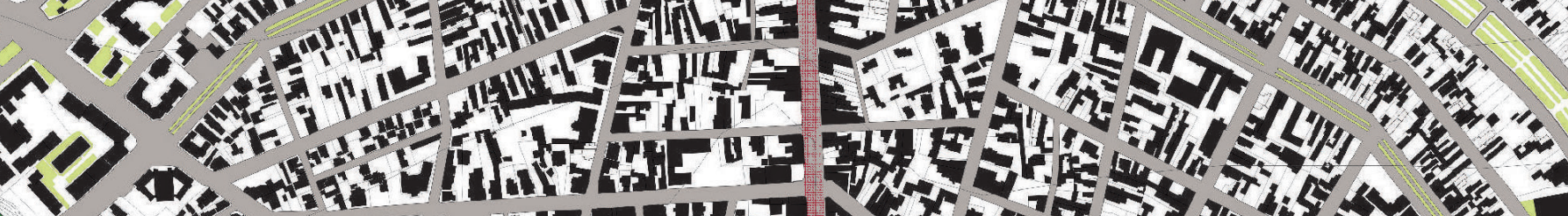

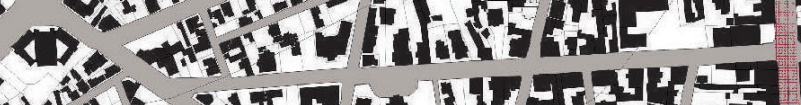

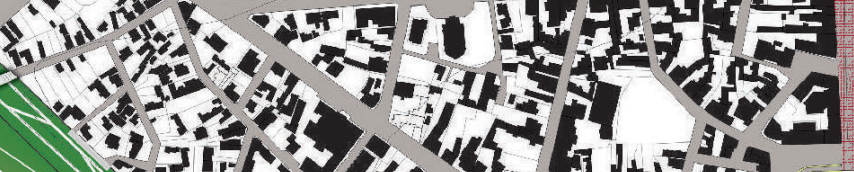

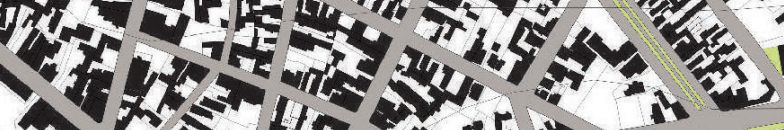

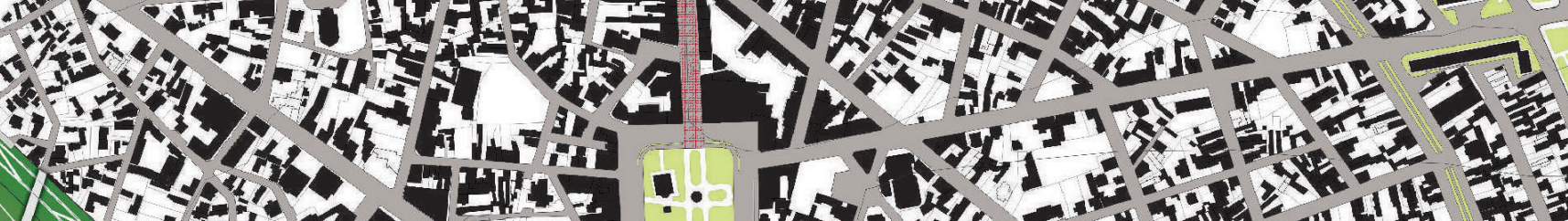

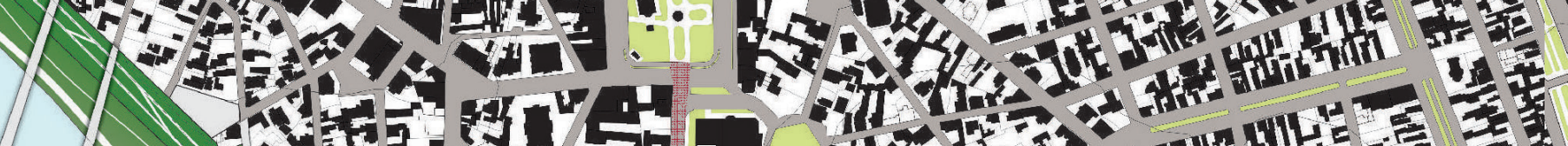
4 (1)

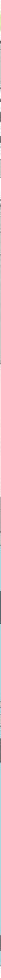




\section{A Promenada - primeira área de intervenção / workshop}

Na sequência da análise e do diagnóstico levados a cabo naquilo que foi a abordagem lógica do projeto, a primeira área tratada em pormenor foi a sugerida para o workshop realizado em Lille, ou seja, a área definida pelo novo centro administrativo da cidade (a Avenida da Independência) e pela Gare Fluvial (Rua do Imperador Trajano). É a zona de passeio existente ao longo da margem. A razão para a escolha desta área foi que, presentemente, ela é a principal zona de ligação entre a cidade e o rio, funcionando como espaço quase público.

O desafio neste caso consistiu, antes de mais, em ultrapassar os obstáculos apresentados pela topografia e em desenvolver novas ligações entre o centro histórico e a frente ribeirinha. Outro aspeto a necessitar atenção foi o do próprio traçado do espaço linear de passeio, de maneira a realçar-Ihe a função de elo urbano, para que se venha a tornar um ponto central de interesse e vá, ao mesmo tempo, ao encontro de todas as necessidades dos seus diversos utilizadores (a cidade dispõe de um número limitado de áreas capazes de corresponder à procura de espaços públicos de qualidade).
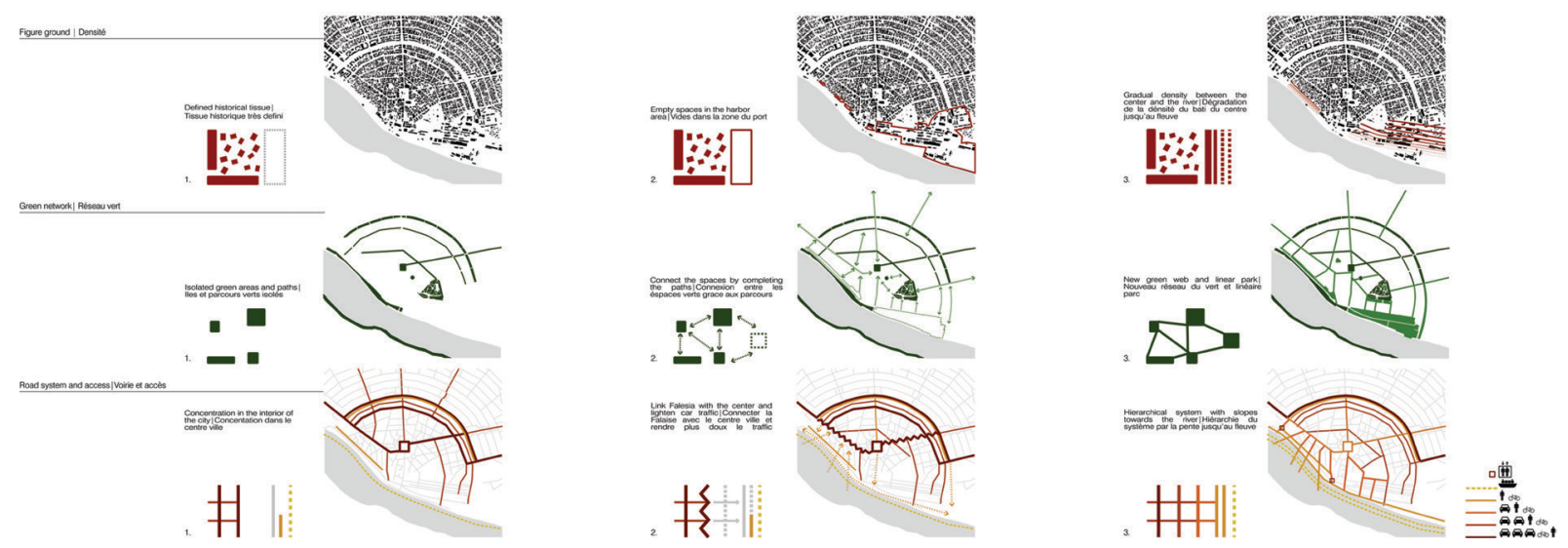

Workshop - A análise

A lógica da solução encontrada assentou na análise prévia, pela equipa, das principais características da cidade e respetiva estrutura e, consequentemente, da área em estudo. Atendeu-se, portanto, à tipologia dos espaços existentes, cuidando de manter a identidade local e, acima de tudo, explorando o topografia do terreno. Aproveitou-se, assim, o desnível - que ao mesmo tempo funciona como barreira entre as duas áreas de maior importância (o centro histórico e a frente ribeirinha) -, desta forma transformado em elemento de ligação. 


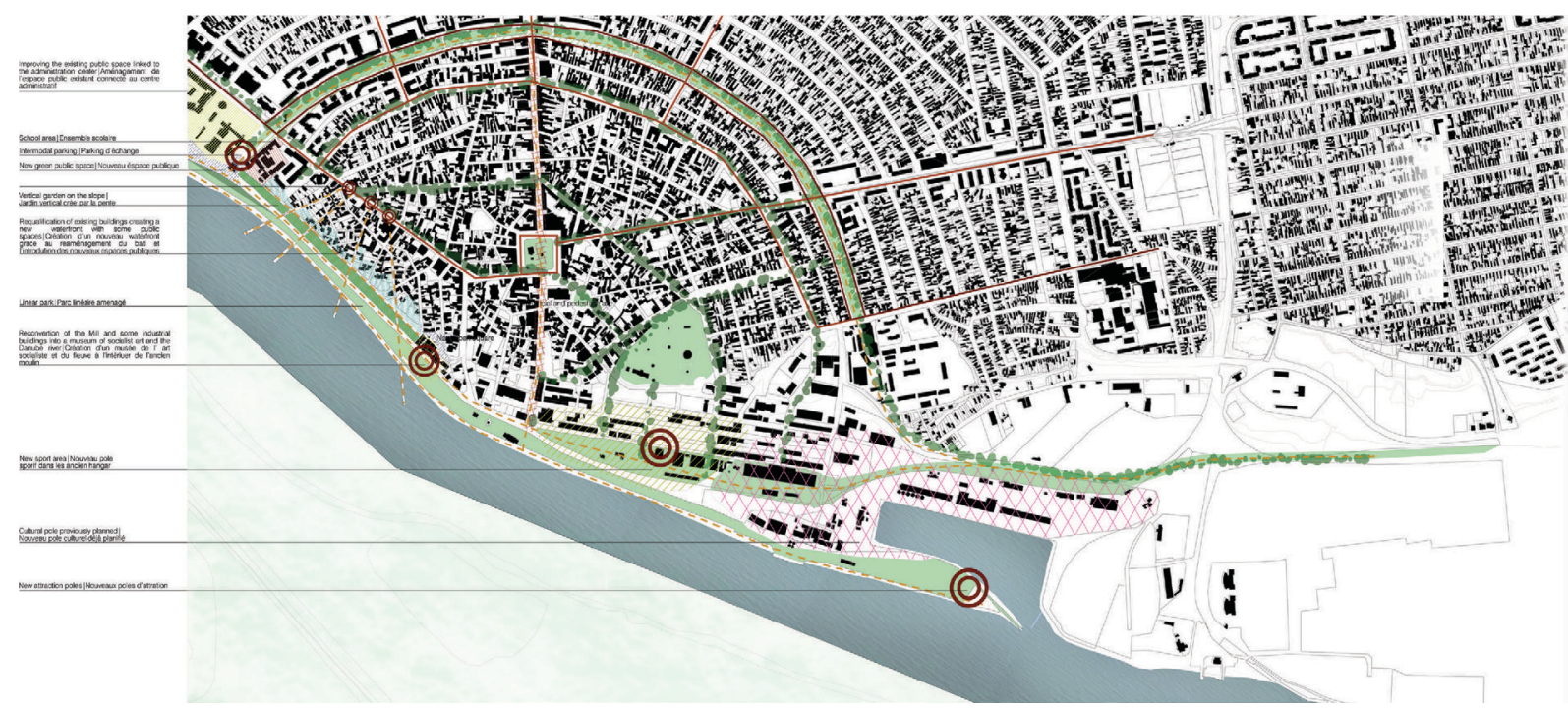

Workshop - A proposta

O principal objetivo do projeto consistiu em reforçar a relação entre a cidade e o Danúbio, conferindo destaque - ou dando origem - a espaços públicos sem deixar de preservar a integridade e a singularidade da estrutura urbana. A proposta centrou-se nos seguintes tipos de intervenção: reabilitação do património arquitetónico e urbano, ligação entre os principais polos de atração e locais de referência, preservação e alargamento da estrutura urbana característica do centro da cidade, e realce da traça desta área.

A acessibilidade foi um dos principais aspetos sobre os quais a equipa fez incidir o seu estudo, por achar que um dos principais problemas em presença era o de conseguir uma melhor ligação entre a cidade e o rio. Este aspeto foi solucionado de diversos modos. Em primeiro lugar, criando vias transversais capazes de direcionar o tecido urbano para a água e, simultaneamente, transpor o desnível abrupto. Em segundo lugar, criando pontos de interesse com vista à utilização do espaço, conferindo-Ihe um uso de interesse público e devolvendo-o, assim, à cidade por forma a que volte a fazer parte do seu sistema. 


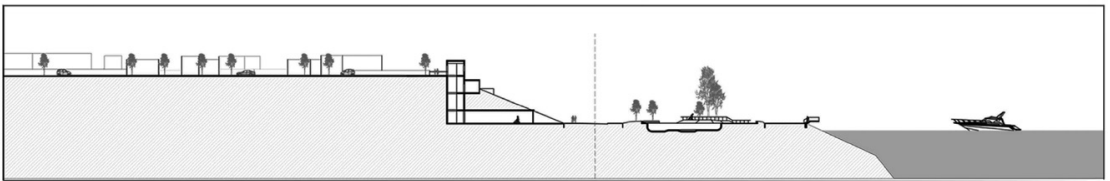

Section trought access for disabled people to the river I Coupe transversale de lacces au flevve pour les personnes handicapés
$1: 500$
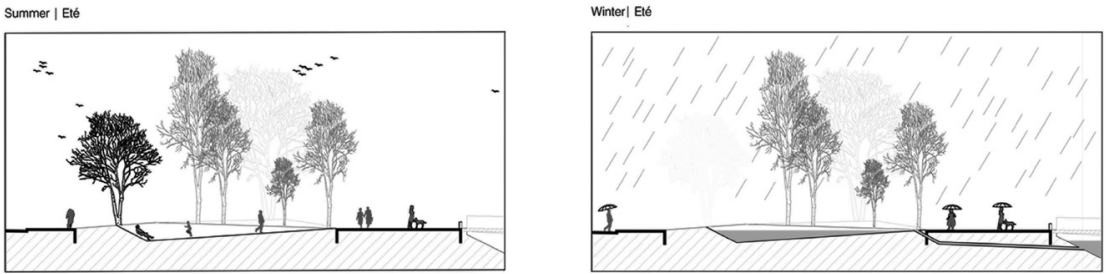

Focus on the game of water levels in the green spacel Zoom sur les jeux d'eau le long de la promenade
1.200
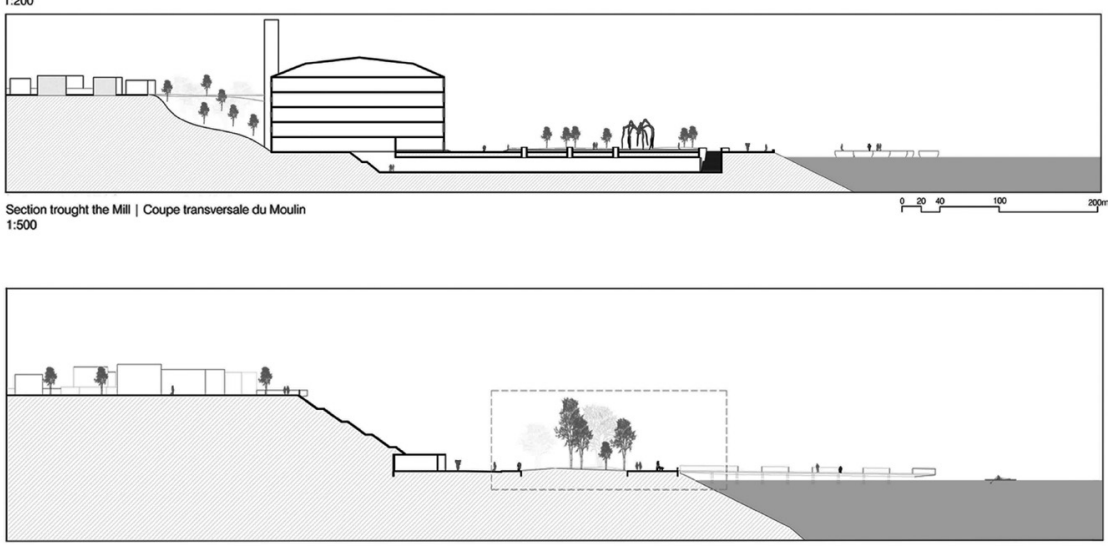

Section trought one of the main access to the river | Coupe transversale de l'acces principal au fleuve
$1: 500$

Workshop - Cortes transversais constantes da proposta

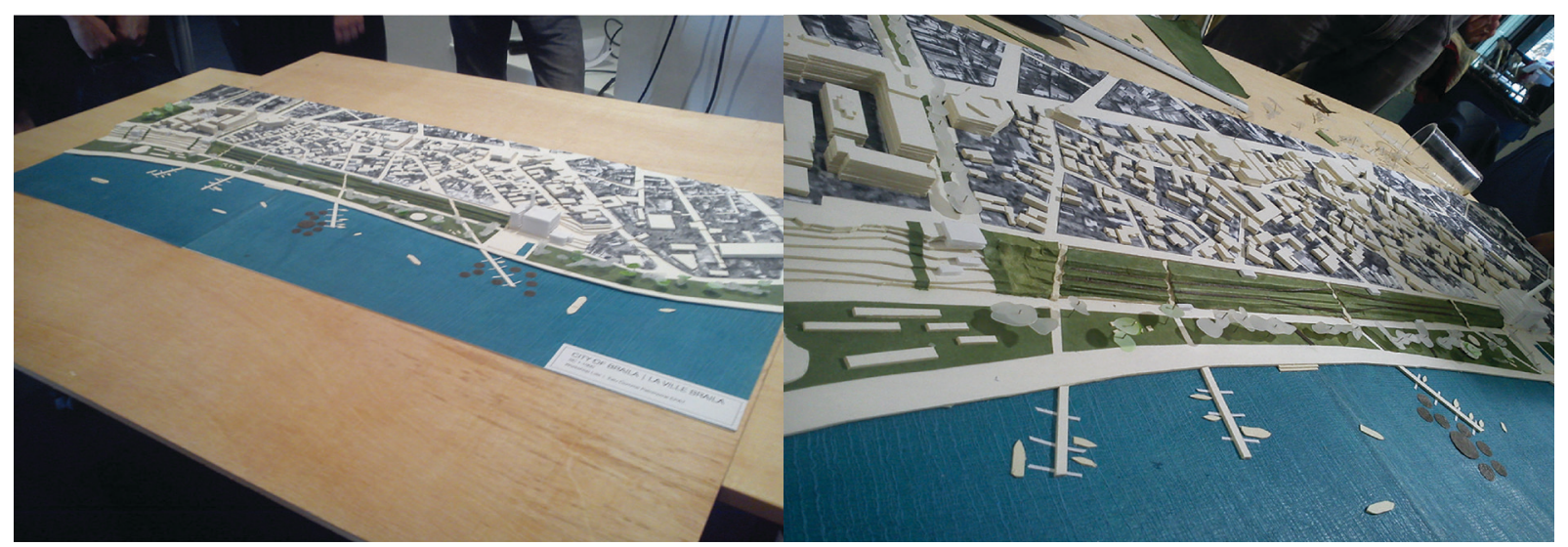

Workshop - O modelo 


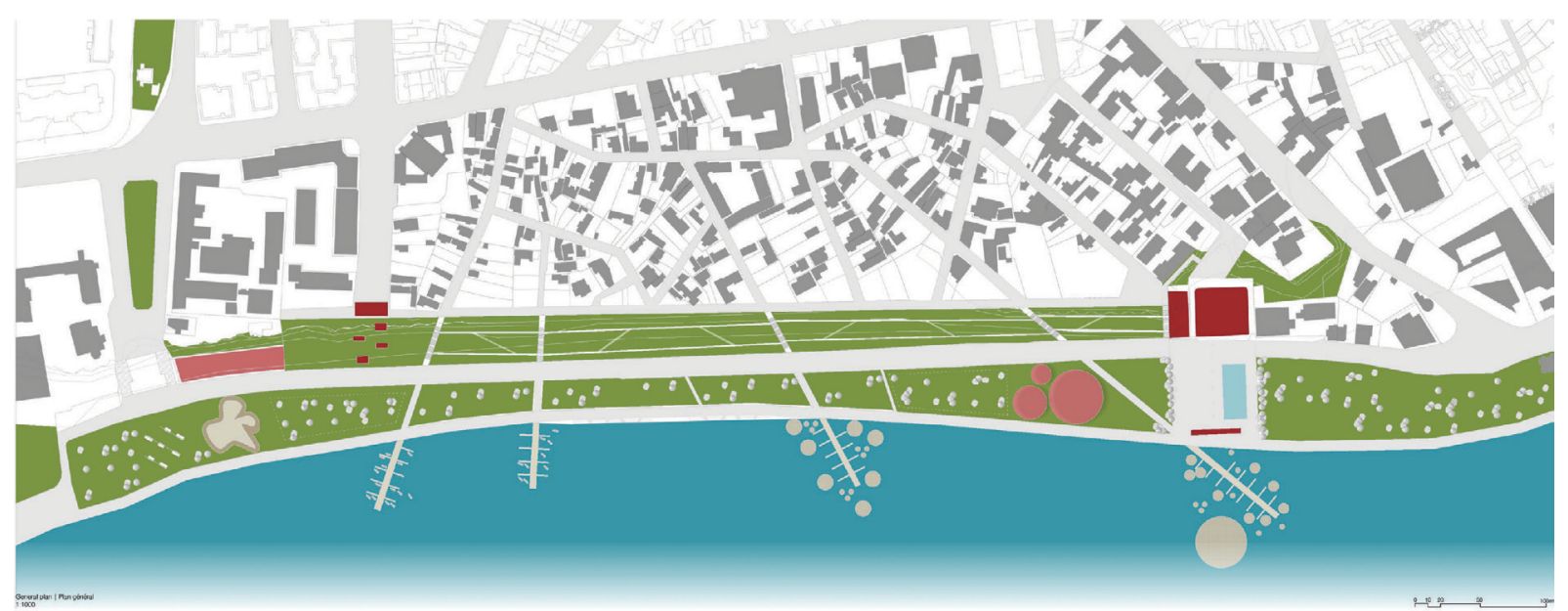

Workshop - A proposta

Uma vez solucionado o problema da acessibilidade, a equipa debruçou-se sobre a questão do desenvolvimento económico, trazendo para a cidade funções rentáveis e reutilizando ou reconvertendo o património edificado existente. A reconversão de edifícios considerados património constitui um passo essencial para a revitalização da economia e de toda a área urbana, visto o património ser um dos elementos-chave para pôr em relação as diferentes áreas com as suas também diferentes características. Além disso, na reconversão do património poderão estar os alicerces de estratégias de revitalização de longo prazo eventualmente aplicáves a toda a cidade. No que diz concretamente respeito ao património urbano e industrial, foi dada especial atenção a um espaço de referência local, a Moagem Violatos, edifício industrial de valor histórico, arquitetónico e urbanístico, hoje em adiantado estado de ruína. A proposta visa transformá-lo em museu, sublinhando assim o seu papel enquanto elemento de ligação urbana (através de pontos de atravessamento e passagens do socalco superior para o inferior). A equipa refletiu sobre a utilização deste espaço como museu, um lugar destinado à recolha, pesquisa, restauro, preservação e exibição de todas as formas de arte entre os anos de 1950 e 1990, um lugar, enfim, destinado a sensibilizar as pessoas para a própria história da cidade de Braila. Por sobre o padrão urbano convencional a equipa propõe, ademais, uma "alteração" do terreno plano, criando pequenos lagos que podem ser preenchidos com água através de alagamento controlado, de maneira a sublinhar e evocar o incomensurável valor ecológico do Danúbio.

\section{Uma segunda área de intervenção - pós-workshop}

Ao formular a resposta para as demais áreas de intervenção tivemos em atenção as intervenções propostas no âmbito do workshop. Assim, se, em relação à zona linear de passeio, a proposta aponta 
para o traçado de um espaço público ao longo da frente ribeirinha e para o prolongamento, como consequência natural, do tecido urbano histórico em direção à água, em relação às demais áreas de intervenção a proposta irá manter a mesma lógica: ou seja, a criação de ligações tanto na direção este-oste como na direção norte-sul. Levámos também em conta as intervenções realizadas em monumentos específicos de interesse local, que podem desempenhar funções diversas na articulação dos espaços. O objetivo principal desta fase é devolver à água a sua função original: a de moldar a forma urbana e de ser a principal força motriz do desenvolvimento económico. Para esta fase, por conseguinte, o projeto centrou-se nas áreas delimitadas pela Gare Fluvial / Rua do Imperador Trajano e na zona do porto (ainda operacional).

1. O prolongamento, em direção ao rio e ao longo do principal eixo histórico - a Rua do Imperador Trajano -, da via pedonal foi consequência da ligação ao rio do principal centro de comércio, localizado no primeiro anel da cidade. Isto foi realizado por meio da "duplicação" da Praça de Trajano até à frente ribeirinha e da criação de um novo espaço público em torno da Gare Fluvial. A nova praça pública tem uma dupla finalidade: irá funcionar como ponto de inflexão para uma via pedonal apontada ao rio, na direção este-oeste, e como términus do parque linear situado ao longo da margem (direção norte-sul). A nova praça funciona como ponto de passagem entre dois tipos de espaço, diferentes entre si dos pontos de vista arquitetónico e funcional. Propomo-nos, ainda, restituir à Gare Fluvial a sua principal função, que é servir os passageiros das embarccações que navegam no Danúbio.

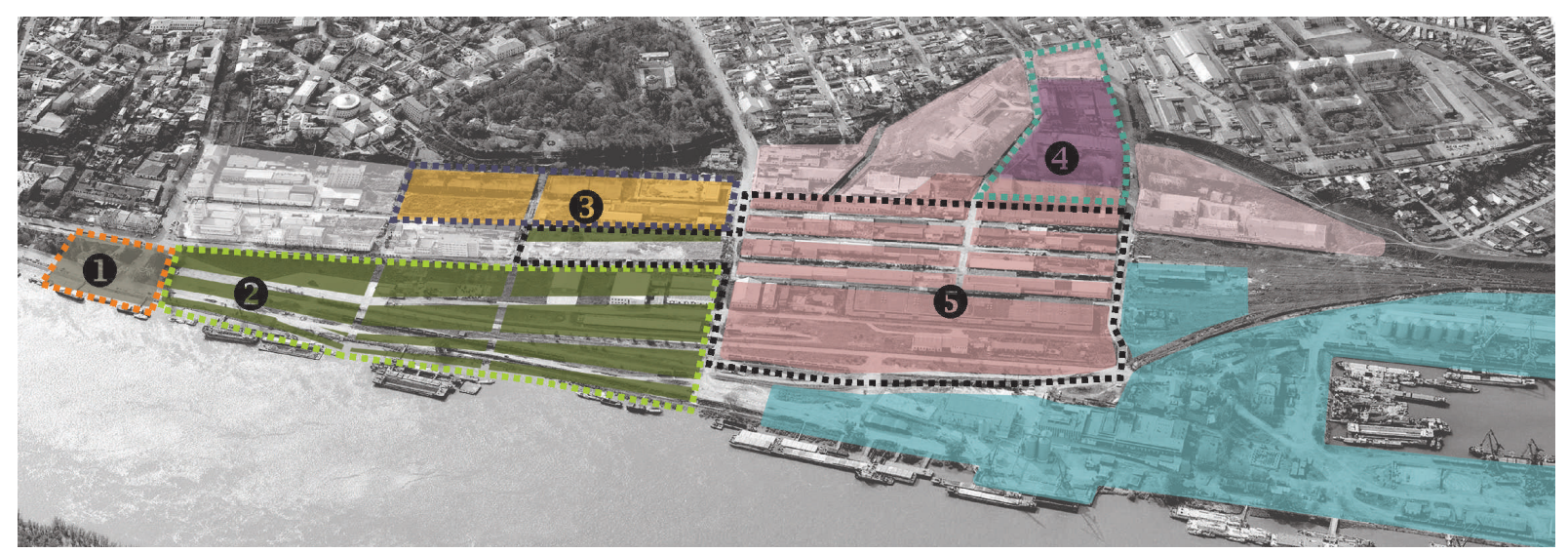

Pós-Workshop - Áreas de intervenção

2. A zona liberta do porto fica simbolicamente "livre de edifícos", de maneira a proporcionar à cidade um espaço flexível, a utilizar de diferentes modos consoante as necessidades de cada momento. O novo espaço assim liberto pode ser ativado por via da extensão das atividades eventualmente a terem lugar nos pavilhões lineares de armazenamento, como feiras periódicas ou outros eventos de 
caráter público. Em relação ao traçado geral, a equipa decidiu que, para restaurar a imagem original, a criação de um sistema mínimo de veredas (a lembrar o tecido urbano original da zona das docas) seria a melhor forma de assegurar a continuidade do aspeto predominantemente linear desta área. O traçado do resto desta zona reveste-se de um caráter subsidiário. É ainda propósito da equipa recuperar a antiga via férrea, hoje abandonada, e que será utilizada como "passagem"/evocação do passado, através de um conjunto de inscrições a assinalar os acontecimentos importantes da longa história de Braila.
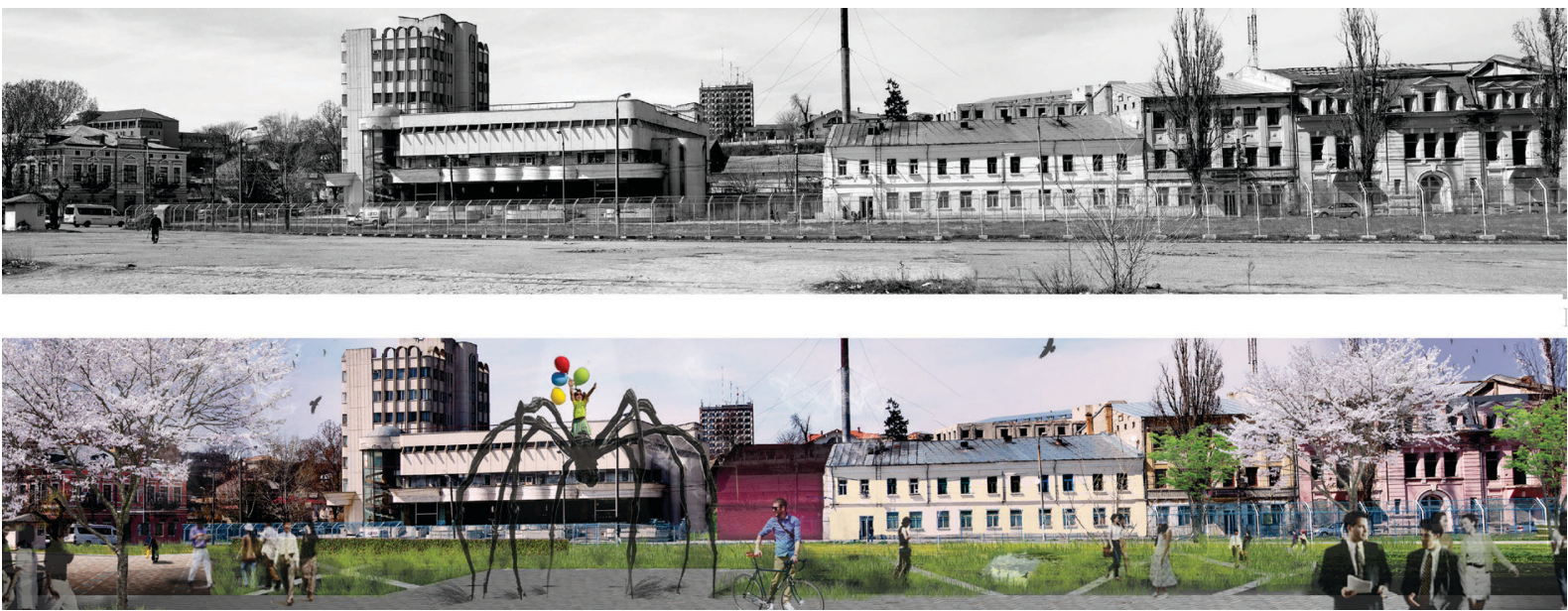

Pós-Workshop - A proposta de uma "zona livre"

3. Um outro marco citadino, o Jardim Público, pode ser considerado o mais "genuíno" ponto de ligação entre a frente ribeirinha e o centro histórico. Ou seja: Tomando por base as cartas antigas de Braila, onde o único ponto de ligação era o jardim, o alargamento do espaço verde desde o socalco superior da cidade até ao socalco inferior constitui uma solução orgânica. Esta função vem acrescentar-se às infraestruturas desportivas existentes. É usada vegetação para criar uma barreira entre a parte de desporto e os pavilhões, mas também para proporcionar a necessária dose de privacidade às zonas residenciais circundantes. Respeitando a topografia natural do terreno, limitámos as intervenções e mantivemos a área de ligação (um declive bastante acentuado) desimpedida de vegetação alta, de maneira a viabilizar o potencial de "miradouro" do terreno mais elevado.

4. Em relação ao património industrial construído, a Moagem Lichiardopulos é, juntamente com a Moagem Violatos, um dos edifícios mais representativos e interessantes. Propomos, por isso, a reconversão do edifício, que poderá de futuro levar a uma revitalização de toda a área circundante. Partindo de uma base espacial flexível, com uma fachada simples e de elementos repetitivos, a solução a adotar deverá passar por uma mescla das seguintes funções: hotel, centro de negócios, auditório para congressos e atividades correlatas. Estas hipóteses surgem como funções de apoio e complemento relativamente ao potencial turístico da cidade e do rio. 


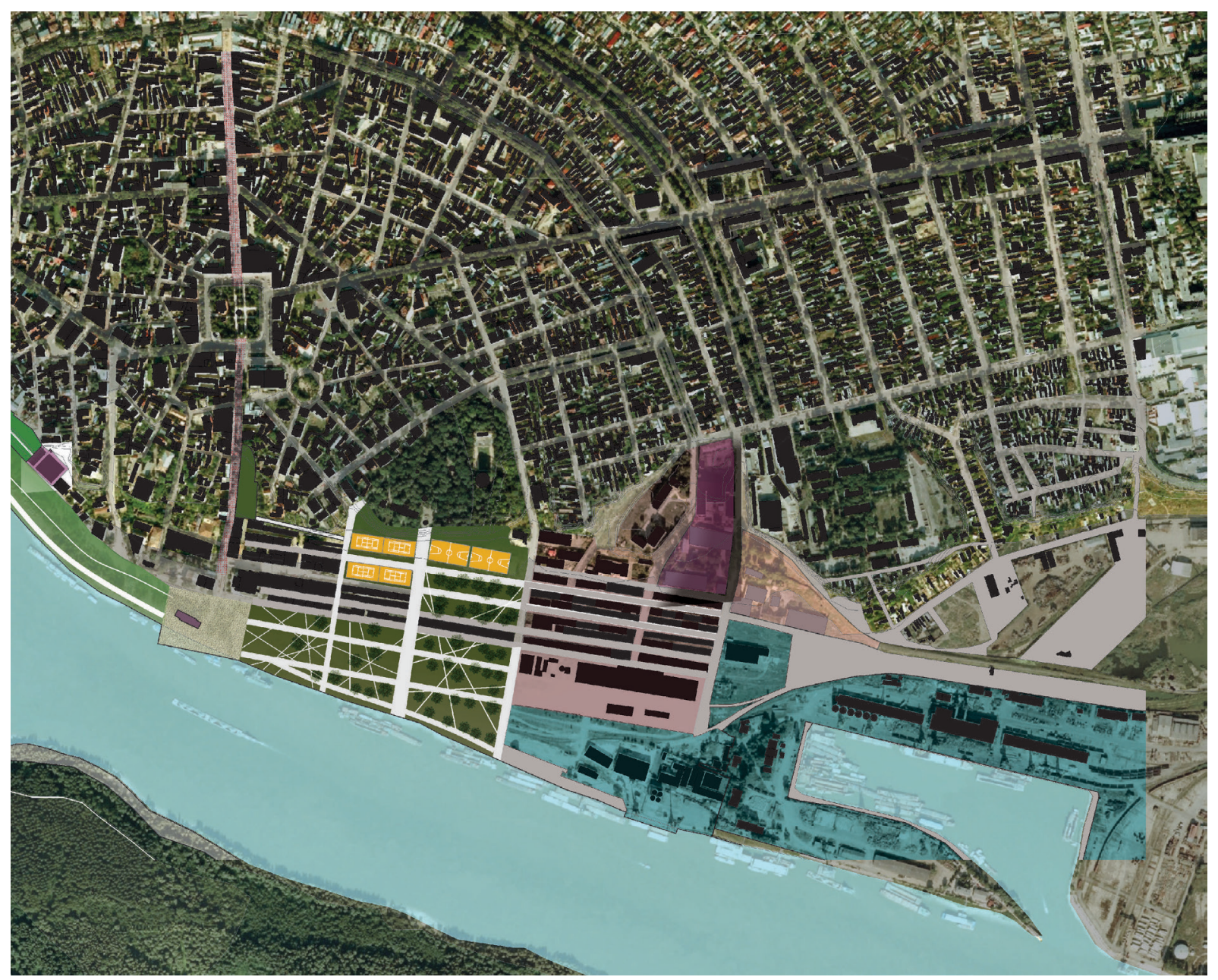

Pós-Workshop - O projeto 

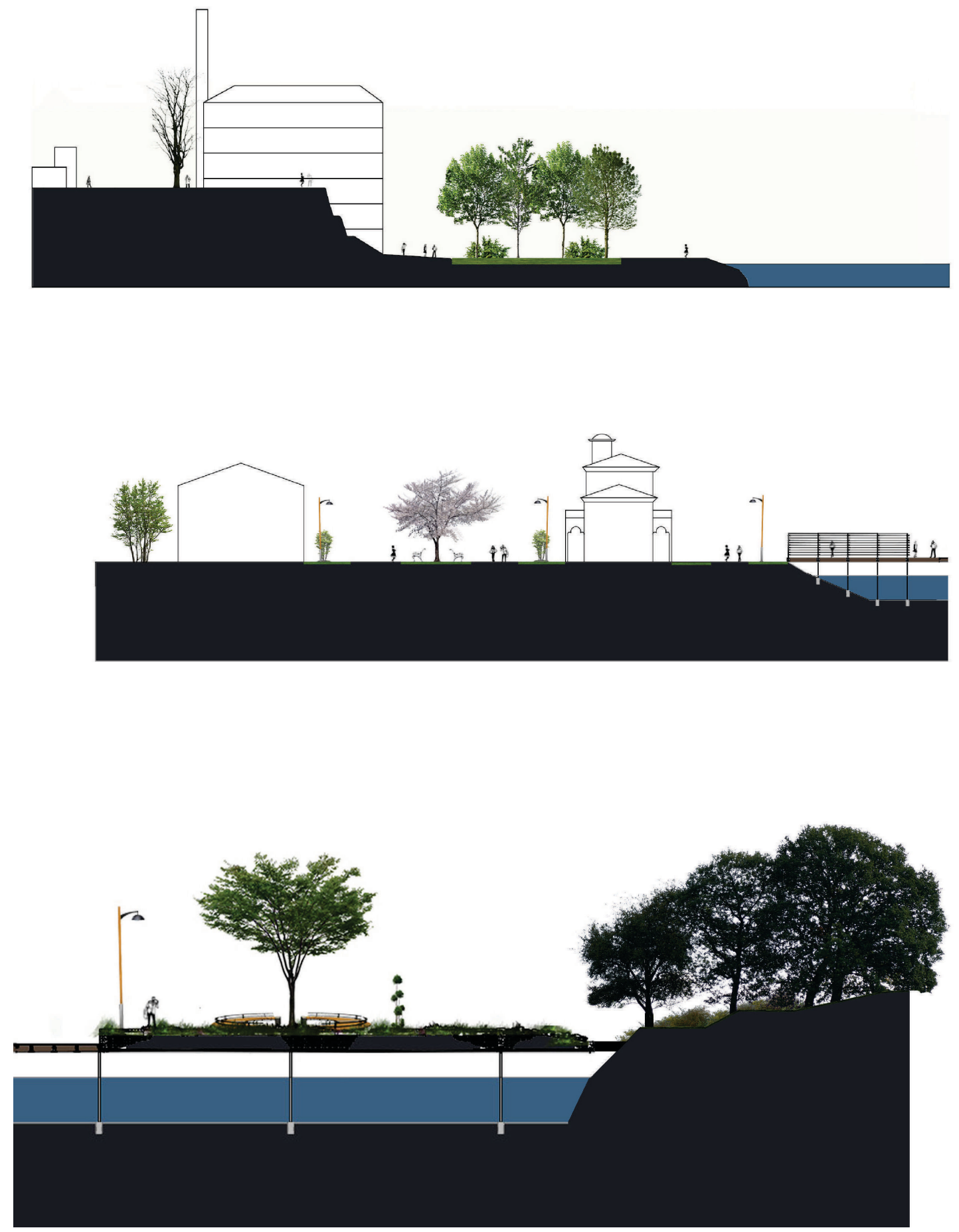

Pós-Workshop - Proposta de cortes transversais para o Jardim Público, Praça da Gare Fluvial, e Ilha Grande de Braila 

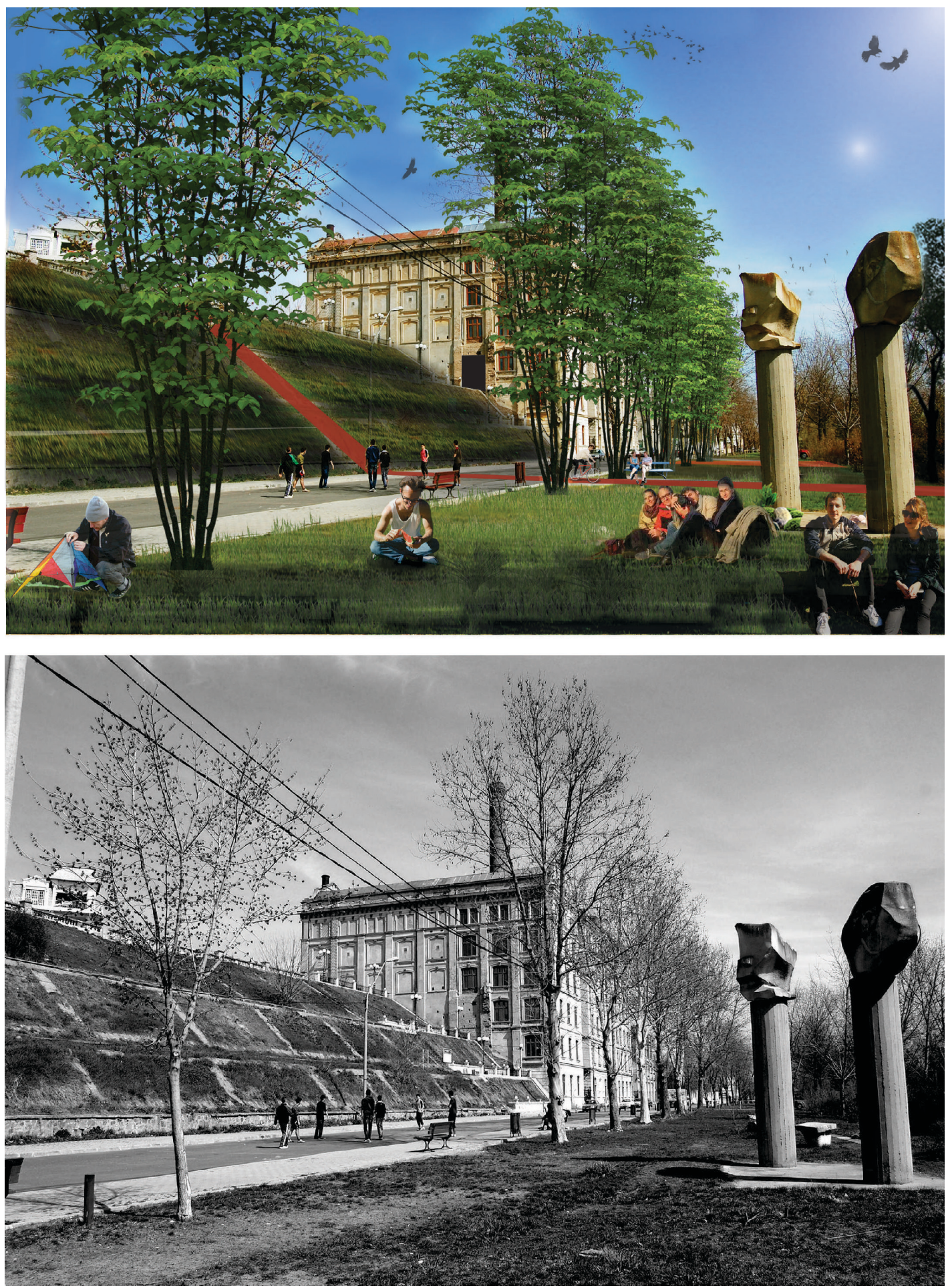

Pós-Workshop - Proposta para a Moagem Violatos 

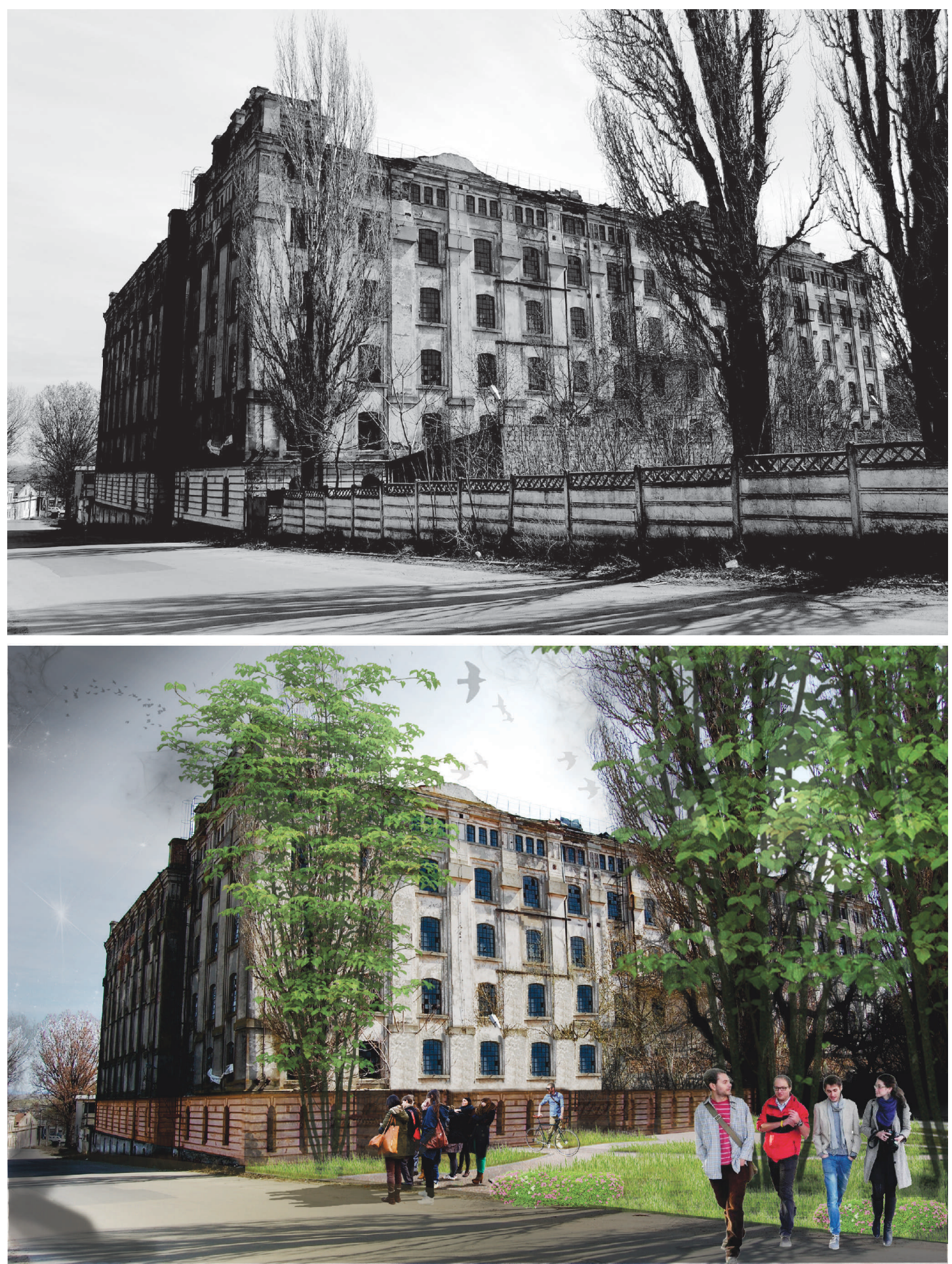

Pós-Workshop - Proposta para a Moagem Lichiardopulos 


\section{Bibliografia}

ANTIPA, GRIGore (1921), DUN Ă REA ŞI PROBLEMELE EI ŞTIINŢIIICE, ECONOMICE ŞI POLITICE. BUCUREŞTI: LIBRĂRILE CARTEA ROMÂNEASCĂ. Braila modernă. Cărţı poştale ilustrate, colecţia Valeriu Avramescu (2006), Muzeul Brăllei \& Editura Istros.

Drăgan, Costel (2012), Scenaril de dezvoltare a sistemului urban Braila - Galati. URbanismul, nR. 12-13, p. 76-78.

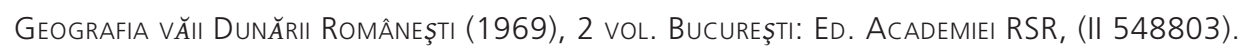

Iosipescu, Raluca e losipescu, Sergiu (2010), Oraşe port la Dunărea de jos şı Pontul nord-Vestic. Urbanismul, nr. 5-6, P. $41-45$.

Lascu, Nicolae (1994), Epoca regulamentară şı urbanismul - cîteva observaţı Generale. Historia urbana, tom II, nR. 2, P. 119-130.

Lascu, Nicolae (2010), Sistemul teritorial Dunăre - Marea Neagră în epoca modernă. URbanismul, NR. 5-6, P. 38-40. Oancea, D. I. (1973), Gruparea urbană Galatı - Bralla. Bucureşti: ed. Academiel RSR.

SÂrbu, Cătălin (2012), Un sistem urban aparte: Bralla - Galati. Urbanismul, nR. 12-13, P. 78-89.

Solomon, Marica (2001), Premise şı evoluţu ale evoluţiel coceptului peisaj cultural, in Peisaj cultural şı dezvoltare. BuCUREŞTI: ED. Universitară ION Mincu, P. 15-32.

Solomon, Marica (2010), Dobrogea ca unitate de peisaj - O abordare CUlturală A teritoriului. URbanismul, NR. 5-6, P. $32-37$.

Stoica, Maria (2009), Braila. Memoria oraşului. Imaginea unui oraş românesc din secolul al XiX-lea. Bralla: Ed. Istros.

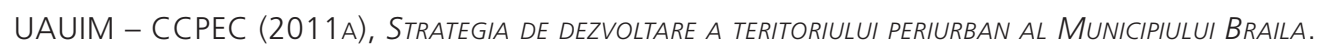

UAUIM - CCPEC (2011B), Atualizare Plan URbanistic General BraILa.

Urban Proiect (2008), Planul Urbanistic Zonal - Centrul istoric al Municipiului Bralla. 
COIMBRA

\section{CIDADE À PROCURA DE UM RIO}

JOÃO PAULO CARDIELOS (Coordenador)

RUI LOBO

PAULO PEIXOTO

EDUARDO MOTA

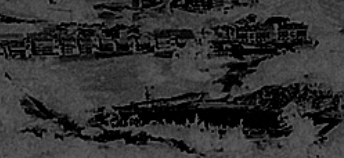




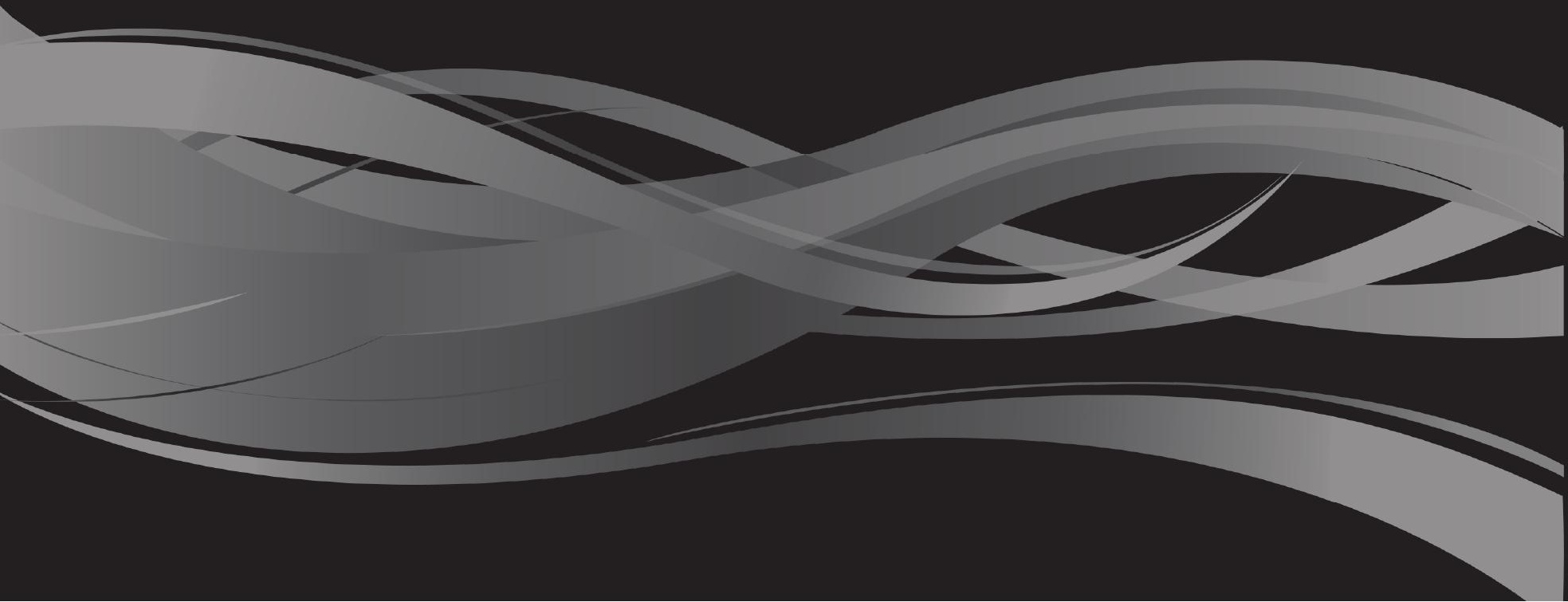


O Mondego marca indelevelmente todas as localidades que cruza. Coimbra não constitui exceção. Toda a frente ribeirinha, instalada sob a sua margem direita, viu estabelecer paulatinamente os usos que o território Ihe exigia, e a construção histórica ampliou essa condição, alargando a área urbana e ligando as cotas altaneiras nas colinas. Estruturou-se uma conexão forte entre a alta da colina defensiva, que é hoje monumental e universitária, e a baixa comercial dos serviços, que já foi pólo industrial e se rendeu décadas, durante todo o século XX, à mobilidade e às exigências várias de progresso, lido e medido por padrões referenciais de épocas que, felizmente, já não vigoram.

Ao longo do curso baixo do rio há outras cidades que, tal como Coimbra, estão a assistir às transformações urbanísticas que se focam hoje em processos de regeneração urbana, e que ambicionam mais do que a construção de novas espacialidades. A revitalização das margens é, há já alguns anos, um desafio complexo do qual faz parte a reconstrução da própria identidade dos lugares. Ao património histórico e monumental de cada lugar ribeirinho, pleno de memórias que envolvem a história deste território - desde a reconquista cristã à fixação das fronteiras do país, e de aí em diante, até ao Portugal europeu que determina o extremo ocidental de uma comunidade de países orgulhosa das suas culturas -, juntam-se hoje as memórias dos homens, as pessoas que construíram as suas paisagens à medida de cada época, e que legaram o palimpsesto (Corboz, 2001) em que hoje se constitui o Mondego.

A natureza fluvial representa hoje, apenas, uma pequena parte de um repositório patrimonial inesgotável que urge estudar e redescobrir, para se poder reinventar e expandir o potencial que as suas margens inquestionavelmente proporcionam, convertendo-o em qualidade do habitar. A melhor maneira de o conseguir será, sem dúvida, através da difusão da informação agregada às memórias do rio, que as populações deverão reconhecer e valorizar, para estimularem e exigirem um reabitar mais sensível e criativo.

\section{O projeto}

O projeto "Eau comme Patrimoine" ofereceu-se como uma excelente oportunidade para alargar o âmbito dos exercícios de diagnóstico e projeto, sobre as realidades ribeirinhas do Mondego. Apesar de centrado na cidade de Coimbra ficou decidido, desde muito cedo, alargar o âmbito geográfico do diagnóstico ao reconhecimento do atual estado do seu curso superior, e também estender parte do projeto à planície aluvial do Baixo-Mondego, e ainda, desenvolver todo o processo metodológico envolvendo estudantes de universos educativos e diferentes grupos etários.

O desenvolvimento do projeto de Coimbra foi definido a partir de três eixos: um primeiro eixo relativo às escalas de elaboração do diagnóstico; um segundo, relativo ao envolvimento de estudantes na elaboração desse diagnóstico; e um terceiro e último, respeitante à organização de debates e eventos públicos sobre o diagnóstico efetuado.

Para efeitos de diagnóstico foram fixadas duas escalas de análise. Uma primeira escala, centrada nas margens do território mais urbano do Mondego, correspondendo à zona situada entre as 
4 pontes que cruzam o rio em Coimbra, que tem sofrido uma importante transformação recente e mantém em curso um processo incompleto, pleno de oportunidades e contradições; uma segunda escala envolve todo o território percorrido pelo rio, com um particular enfoque para o trajeto fluvial que vai de Coimbra à Figueira da Foz. Atribuiu-se ainda uma atenção especial à foz do rio, junto à cidade da Figueira da Foz, onde os debates em curso sobre o planeamento urbano indiciam, também aí, importantes transformações urbanas a empreender futuramente.

Considerando estas duas escalas, foram desenvolvidas várias iniciativas, de modo a efetuar um diagnóstico que pudesse enquadrar a elaboração do projeto e orientar o workshop realizado em Lille, em maio de 2012. As iniciativas ganharam visibilidade, num primeiro momento, através da conceção do site http://www.ces.uc.pt/epat e, num segundo momento, a partir da realização de eventos científicos, workshops, exposições e debates.

A concretização do projeto envolveu alunos de vários níveis e instituições. Alunos do Departamento de Arquitetura da Faculdade de Ciências e Tecnologia da Universidade de Coimbra. Alunos de Sociologia da Faculdade de Economia da Universidade de Coimbra. Alunos da disciplina de Geografia A, da Escola Secundária Dom Duarte, em Coimbra, coordenados por Edite Rico. Alunos da Disciplina de Geografia, da Escola Secundária de Cristina Torres, na Figueira da Foz, coordenados por Fernanda Craveiro. Globalmente, para além de contribuir para cumprir um dos objetivos do projeto, este envolvimento visou ainda: introduzir questões relativas aos rios, paisagens fluviais e usos da água nos conteúdos curriculares; fomentar um cruzamento de fontes documentais e orais que permitissem enriquecer o diagnóstico; potenciar a interação institucional e também entre alunos de vários níveis de ensino; promover a participação e o debate público; e, por fim, contribuir para a elaboração do projeto.

Os estudantes do Departamento de Arquitetura que foram envolvidos no projeto integraram três grupos distintos:

Um primeiro grupo de estudantes, da unidade curricular "Projeto V", estudou desde o início do projeto EPAT, no ano letivo de 2010-11, as frentes ribeirinhas da cidade de Coimbra e a complexidade do sistema de mobilidades urbanas, regionais e nacionais, tanto rodoviárias como ferroviárias, que envolvem as travessias do Mondego e os seus impactes na qualidade e vivências do rio. Estes estudantes compuseram ainda o diagnóstico geográfico e urbano da história da cidade de Coimbra, e do seu planeamento recente, e fundamentaram, à luz da teoria urbana, os processos em curso. Depois, cruzaram toda esta informação com os desejos e ambições expressos por inúmeros grupos ou iniciativas de cidadãos, difundidos pelos meios de comunicação social locais, ou veiculados em iniciativas de grupos de cidadãos participativos independentes, que auscultaram. Estabelecidas as bases de projeto avançaram para o desenho sobre as áreas de potencial transformador mais relevantes, procurando enquadrar os desejos e ambições com os registos mais inovadores, que o discurso atual sobre a regeneração urbana pode proporcionar.

Um segundo grupo, idêntico ao anterior, trabalhou já no ano letivo de 2011-12, sobre as transformações em curso no Baixo-Mondego e sobre as frentes ribeirinhas da cidade da Figueira da Foz, junto ao Oceano Atlântico, seguindo as mesmas orientações metodológicas do grupo anteriormente referido. 

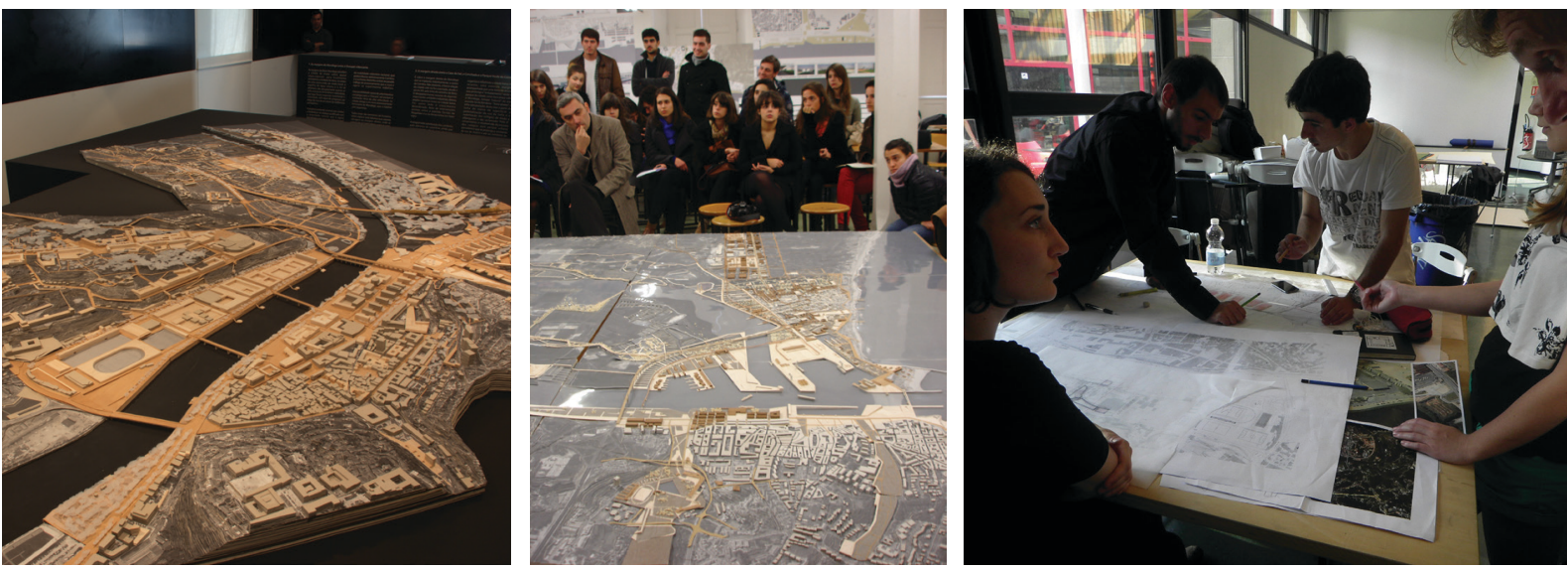

Do trabalho destes dois grupos de estudantes, coordenados pelos docentes Gonçalo Byrne, Nuno Grande, Rui Lobo e João Paulo Cardielos, resultaram duas exposições e dois debates públicos, realizados respetivamente nas cidades de Coimbra e da Figueira da Foz, envolvendo representantes políticos das duas autarquias, técnicos dos serviços municipais de urbanismo, técnicos de organismos ambientais do estado português, e ainda outros, ligados à gestão das principais infraestruturas regionais, e representantes de grupos de cidadãos independentes e de organizações ambientalistas. As exposições intitularam-se: "COIMBRA REINVENTADA: visões urbanas para as margens do Mondego", realizada no âmbito da semana cultural da Universidade de Coimbra, que esteve patente de 2 de março a 3 de abril de 2011 no Museu Nacional de Machado de Castro; e, "VISÕES URBANAS PARA A FOZ DO MONDEGO: um futuro possível para a Figueira da Foz ", realizada na Casa do Paço, de 12 de julho a 16 de setembro de 2012 .

Por último, um grupo de estudantes universitários mais novos, da unidade curricular de "Desenho II", e no mesmo ano letivo de 2011-12, trabalhou sobre o imaginário como património, nas artes plásticas, tendo como tema o rio Mondego. No âmbito desta unidade curricular, sob coordenação de António Olaio e de Pedro Pousada, foi realizada entre 14 de fevereiro e 11 de abril de 2012, no Museu da Água, em Coimbra, a exposição "O Rio Voador".

"No Museu da Água, as peças dos alunos dos cursos de Arquitetura e de Design e Multimédia da Universidade de Coimbra, na proximidade do rio Mondego, surgem como sendo seu eco e deriva. Os alunos de "Desenho II", do curso de arquitetura, (...) criaram uma peça suspensa estendendo-se longitudinalmente na sala de exposições, azul, linear, como abstração ou síntese da ideia de rio, feita da junção de peças criadas individualmente por cada aluno. Este 'rio voador', assim autonomizado, nasce da ideia de um rio que concentra em si as próprias margens, síntese da ideia de que um rio inclui as suas margens. E, na contaminação da ideia de arquitetura, este rio é um rio construído. Solidez tornada fluída, nestas formas que se estendem como um rio.

Nas paredes da sala expuseram-se os trabalhos dos alunos dos cursos de Design e Multimédia: os alunos de "Desenho e Representação" (coordenados pela professora Alice Geirinhas), em papel recortado, fazem eco do curso linear deste rio imaginado, em silhuetas que se espelham como margens que 
se refletem, mas o reflexo é outra coisa, num rio que cria a sua própria realidade; os alunos de "Estudos de Composição" (coordenados por A. Olaio), com imagens projetadas, mostram composições de letras que, em vez de produzir texto, significado, produzem o sentido de um fluxo de formas. Evocando o sentido de um discurso, mas sendo sobretudo exploração plástica de uma condição pré-discursiva.

De facto, em qualquer produção plástica, a essência é sempre o pensamento. Aqui, o pensamento encontra na ideia de rio uma tradução simbólica eloquente. No rio onde nos podemos espelhar para nos vermos, reconhecermos, mas em imagens cujos contornos se tornam mutáveis, dinâmicos, por força da superfície de um espelho em permanente movimento". (Transcrição, com pequenas adaptações, do texto de António Olaio, no Catálogo da Exposição "O Rio Voador")

Outros estudantes, do curso de Sociologia da UC, envolveram-se no projeto no âmbito de duas unidades curriculares. No âmbito de "Fontes de Informação Sociológica" procederam à pesquisa e análise de fontes documentais sobre o Rio Mondego e sobre planos e projetos de intervenção nas margens do rio, tendo realizado trabalhos que estão publicamente disponíveis em http://www.ces. uc.pt/epat. Os alunos de" Amostragem e Inquérito" conceberam e realizaram um questionário sobre a Água e o Rio Mondego em Coimbra. O inquérito procurou captar informação sobre a forma como a população residente na cidade se relaciona com o rio Mondego e os recursos hídricos. Aplicado em quatro zonas residenciais distintas - Solum, Conchada, Baixa da cidade, e ainda, nas urbanizações em torno da Quinta das Lágrimas/Nó das Lages, na margem esquerda -, permitiu analisar comparativamente como diferentes segmentos de residentes em Coimbra usam o rio e as suas margens, e que perceções têm acerca da sua importância para a cidade, das medidas públicas com ele relacionadas, e das formas como é aproveitado na área urbana que atravessa.

Os alunos de Geografia A, da Escola Secundária Dom Duarte, em Coimbra, realizaram duas atividades distintas:

A primeira, designada "Áreas rurais em mudança", incidiu sobre o Baixo Mondego e permitiu: identificar espécies animais e vegetais, caracterizar a sua interdependência e importância para o equilíbrio da biodiversidade e a proteção ambiental local e nas explorações agrícolas; mostrar de que forma a abundância de cegonhas no Baixo Mondego e a técnica utilizada para as afastar dos arrozais reflete a preocupação com o desenvolvimento sustentável; caracterizar as alterações no sistema agrário do Baixo Mondego, resultantes das obras de regularização do rio ao longo de décadas.

A segunda foi especificamente orientada para a "Análise do Parque Verde do Mondego", e permitiu: elaborar cartografias de sensações desta nova área/parque urbana; caracterizar e avaliar os reflexos da aplicação do Programa Polis Coimbra; efetuar um levantamento funcional do Parque Verde do Mondego; e reter indicadores de requalificação no Mosteiro de Santa Clara A Velha.

Por sua vez, os alunos da Disciplina de Geografia, da Escola Secundária de Cristina Torres, na Figueira da Foz, realizaram várias pesquisas sobre o tema "Novas utilizações da água: o estuário do Mondego". O principal objetivo do trabalho foi dar a conhecer algumas atividades que se realizam no estuário do Mondego e que demonstram a importância da água para diversas áreas da vida das comunidades locais. O estuário do Mondego é uma área que se estende desde sensivelmente Montemor-o-Velho até à foz 
do Rio Mondego, junto à cidade da Figueira da Foz. É uma área vasta, onde decorrem várias atividades económicas, e é utilizada para a indústria, a agricultura, a caça, a pesca, a aquacultura, a salicultura, além de variadas atividades de turismo e recreio. O estuário do Mondego possui um grande valor para as aves pois constitui-se como ponto de passagem e paragem obrigatória para algumas espécies. São especialidades nesta área o flamingo-comum, a águia-pesqueira, o gaivotão-real e o estorninho-malhado. Para além destas, há uma vasta lista de outras espécies que tornam todo o salgado, e particularmente o sítio da Ilha da Murraceira, como lugar de grande interesse ornitológico. Por tudo isto, o estuário do Mondego é um Sítio Ramsar. Os trabalhos realizados pelos alunos incidiram particularmente sobre: a salicultura, a aquicultura, as atividades desportivas e o turismo. Com esses trabalhos os alunos procuraram dar conta da forma como as comunidades locais realizam estas atividades, e de como usam a água e fomentam o seu uso de modo sustentável e ambientalmente amigável.

Além das já referidas exposições e debates públicos, promovendo a transição entre a fase do diagnóstico e a do projeto, vários outros eventos científicos contribuíram para a realização deste projeto. Salientamos a realização do seminário internacional "A água como património - a importância das paisagens fluviais para as cidades e as comunidades locais", que teve lugar em Coimbra entre 13 e 15 de fevereiro de 2012. Além da participação dos parceiros locais e internacionais envolvidos no projeto EPAT, o seminário permitiu: discutir um plano de orientação para a bacia fluvial e zonas adjacentes e, ao mesmo tempo, pensar um plano que preveja estratégias de ligação e articulação com as cidades; discutir ideias que perspetivem uma ligação mais eficaz entre os projetos relativos às áreas urbanas e ao rio; e que permitam "viver" o rio e devolver-lhe o seu papel de protagonista privilegiado na organização das cidades, e no usufruto das áreas naturais próximas ou envolventes.

Organizou-se ainda um workshop, dinamizado por especialistas internacionais em projetos fluviais, integrando os alunos envolvidos no diagnóstico e no projeto de Coimbra, que teve lugar em Coimbra em 3 de outubro de 2011.

Realizou se também uma outra exposição, denominada "As areias do Mondego: da extração à construção", realizada no Mosteiro de Santa Clara-A-Velha, de 19 de outubro de 2012 a 10 de fevereiro de 2013. Esta exposição permitiu discutir a importância do Rio Mondego no desenvolvimento dos sistemas construtivos locais, de Coimbra e da Figueira da Foz, mostrando que, nas areias que constituem os rebocos tradicionais, surgem tipos de rocha provenientes de diferentes regiões, sendo algumas longínquas, que vêm arrastadas pelas águas do rio Mondego e dos seus afluentes, desde a sua nascente na Serra da Estrela.

\section{Ensaios e contributos académicos para transformar as margens ribeirinhas de Coimbra e da Figueira da Foz}

Os estudantes do curso de mestrado integrado em arquitetura prepararam um conjunto de propostas urbanísticas que resultaram dos diagnósticos previamente efetuados. As situações escolhidas 
como zonas de intervenção prioritárias diferiram bastante. Foram atendidas as experiências urbanísticas previamente desenvolvidas, sobre as margens do Mondego, e as áreas de oportunidade mais relevantes, face aos programas identificados e ao potencial ou relevância dos resultados que as intervenções poderiam potenciar num futuro próximo.

\section{Coimbra Reinventada...}

Coimbra revelava já, à data do início do projeto, um conjunto de iniciativas desenvolvidas ao longo das últimas duas décadas que eram, efetivamente, significativas para a transformação das margens, e para a perceção que a cidade e os seus cidadãos começavam a adquirir acerca da importância do rio, para a sua própria reinvenção. Tratava se não só da espacialidade e valor natural do leito urbano mas, sobretudo, da redescoberta da sua condição aprazível, da possibilidade de um desfrutar da proximidade da água, tanto tempo esquecida ou relegada para uma condição distante e inacessível.

Depois de décadas de um afastamento marcado pelo corte infraestrutural ferroviário e pelos muros de proteção que suportaram o estabelecimento industrial, nos últimos anos a cidade começou a registar uma progressiva aproximação à frente de água. O programa público de valorização das margens do rio Mondego iniciou-se na margem direita, a montante da Ponte de Santa Clara, com as intervenções nos espaços ajardinados do Parque Verde do Mondego, e com a sua ligação e recuperação ao velho jardim público, o Parque Manuel Braga. Passou depois para a margem esquerda onde se desenvolveram sucessivas ações, que a ponte pedonal e ciclável Pedro e Inês veio relacionar com a primeira fase. A requalificação dos espaços públicos que marca todo o programa foi complementada por um conjunto amplo de equipamentos. Destaca-se o projeto de articulação do Jardim de Santa Clara, que desenha também a porta poente do Parque Verde, com a construção da ensecadeira que faz a conservação e valorização do lugar arqueológico do Mosteiro de Santa Clara A Velha - a que se juntou a construção da nova unidade museológica e centro interpretativo, agraciados com o "Prémio
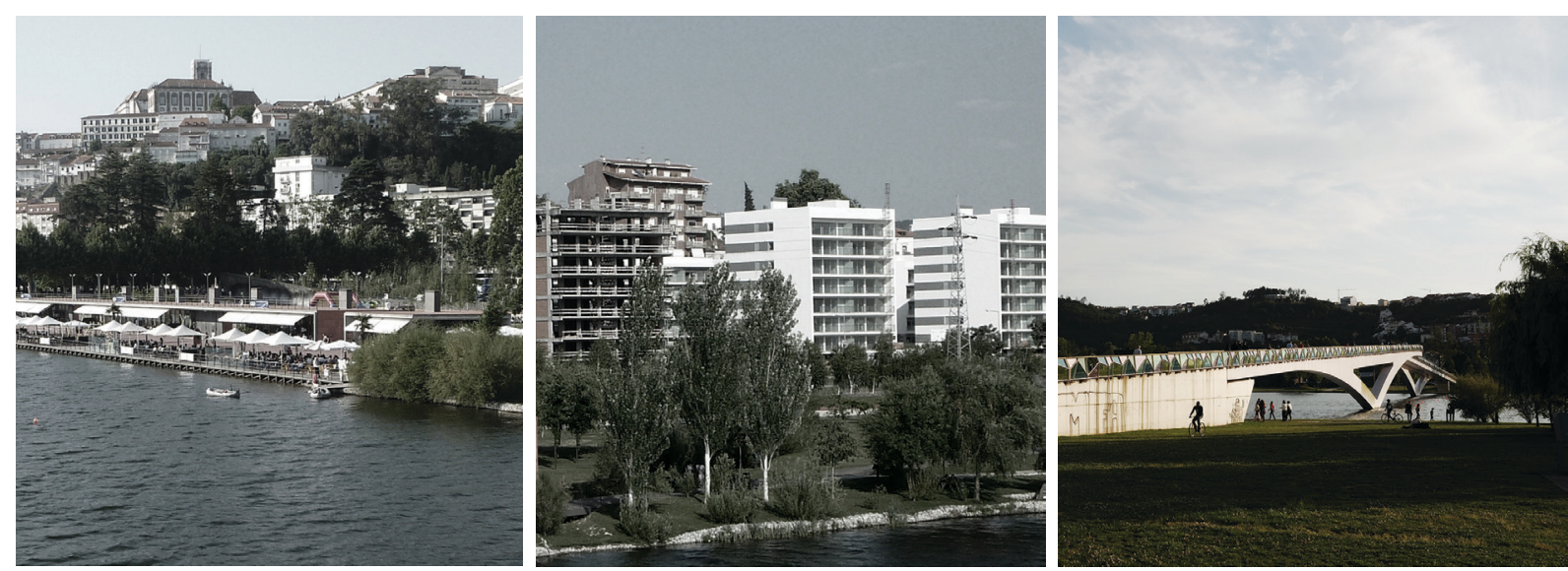
Europa Nostra". Estes espaços abrem-se para a Praça da Canção, o novo recinto de festividades académicas, instalado junto à Ponte de Santa Clara, sobre a margem esquerda do rio. Daqui parte um novo canal que desenha o parque poente e se funde com o rio junto às instalações de recreio náutico, dos campos desportivos informais e dos estacionamentos de apoio. Um pouco mais a sul, as novas Piscinas Municipais e o Exploratório Ciência Viva rematam o conjunto, preparando o principal ponto de acesso rodoviário a esta margem esquerda ajardinada e pedonalizada, bem equipada, junto ao reformulado Nó das Lages. Contudo, esta ampla rotunda rodoviária configura e representa claramente o mais grave problema instalado ao longo de toda a margem esquerda, que é criado pelo atravessamento da via rápida rodoviária, de nível nacional - o itinerário complementar número 2, IC2. Este problema foi questionado pelos projetos académicos, que reconfiguraram todo o modelo de circulação e controlo de fluxos instalado. Ao redefinirem as mobilidades e afastarem o tráfego de atravessamento, os estudantes potenciaram o alargamento de uma ocupação de tipo urbano, principalmente sobre o troço ainda não intervencionado desta margem, entre as pontes de Santa Clara e o Açude, mais a norte.

Os investimentos públicos, emblematicamente marcados pelo Programa Polis Coimbra, estimularam o investimento privado nas duas margens e as novas urbanizações começaram a aparecer e a envolvê los, nas Lages, na Quinta das Lágrimas, mas também na Av. da Lousã. Também a Universidade de Coimbra, mais a sul, havia iniciado e mantém em curso a instalação do Pólo II, das escolas de Ciências e Tecnologias, entre o pinhal de Marrocos e a Av. da Boavista, já a montante da Ponte Rainha Santa. Ainda mais longe, na Portela, está a estabelecer-se um outro importante bairro residencial. Todas estas implantações residenciais ou mistas reforçam a inversão de um processo longo, que outrora ficou marcado pela dispersão pelo interland urbano, e que agora se faz reaproximando as novas áreas urbanas da frente de água, revalorizada pela mudança de sensibilidades e valor, já indisfarçáveis. Na dobra sul do Mondego, na aproximação ao centro urbano, estava pois em curso e corrigia-se a velha indiferença ou temor que marcara a recusa do rio, tanto tempo prolongada.

Ao contrário, importava definir em projeto uma estratégia para a zona norte, a jusante da Ponte de Santa Clara, que confronta a cidade histórica. Muito marcada pela presença quase exclusiva de
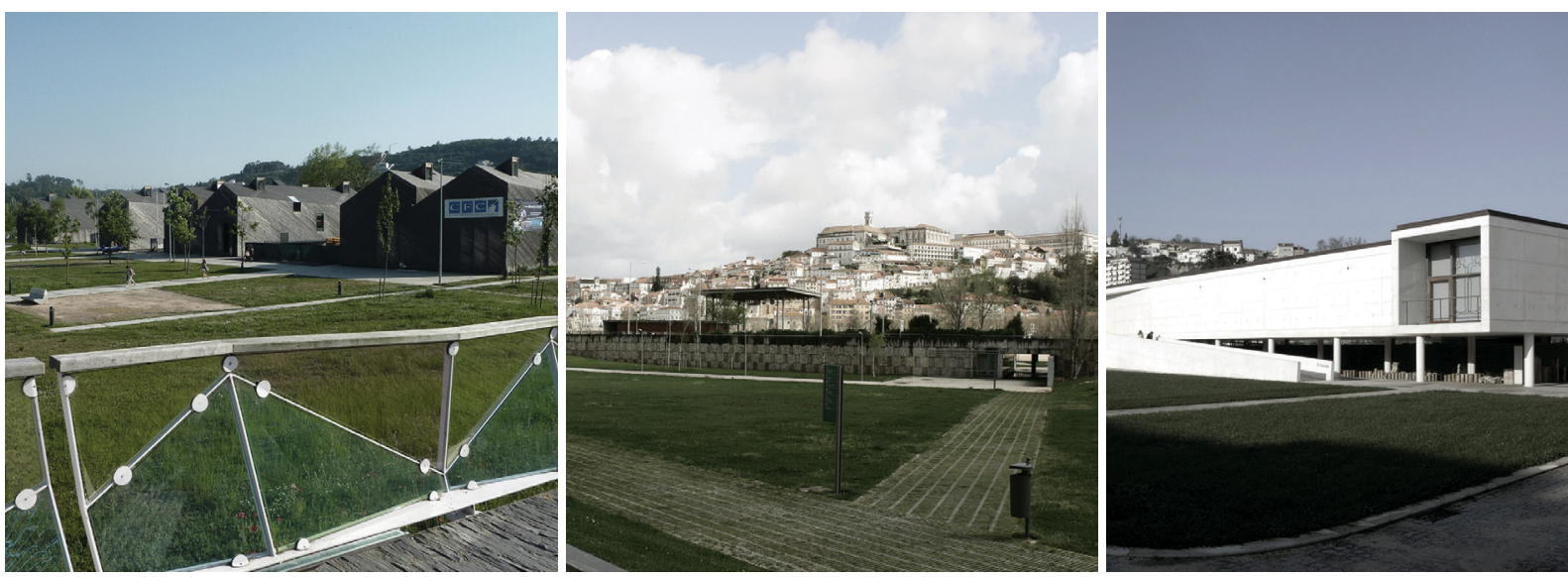
infraestruturas rodoviárias pesadas, antigas e recentes, e pelos espaços residuais e incaracterísticos, ou sobrantes, que sempre ocorrem nestas situações, aqui tudo estava por fazer. Os programas previstos ou desejados envolvem a instalação de importantes equipamentos que a cidade tradicional, na margem direita, não tem capacidade de acolher, devido à escassez de área e à necessidade de zonas públicas relevantes, que a apertada malha urbana consolidada inviabiliza. Assim sendo, na margem esquerda, onde se situa o Centro Desportivo Universitário - fruto de um processo longo e descontrolado de adições - e uma escola, além de enormes áreas residuais ou expectantes, marcadas pelo peso excessivo do já referido atravessamento rodoviário, foi prevista a instalação da nova Cidade Judiciária, de uma unidade hoteleira, além do redesenho da própria escola e do centro desportivo existentes, e do tratamento da frente de água, como extensão do programa de parques já instalado a sul da ponte de Santa Clara. Mais acima na encosta, o Convento de S. Francisco está a ser adaptado para Centro de Congressos, e o projeto previu a reabilitação do marcante Convento de Santa Clara A Nova como equipamento cultural. A clivagem de cotas que marca a escarpa da Guarda Inglesa justificava o desenho, desenvolvido em projeto, de um meio de transporte funicular, alternativo, de ligação às cotas mais elevadas, onde se projetou um novo bairro residencial, com vista sobre a cidade antiga.

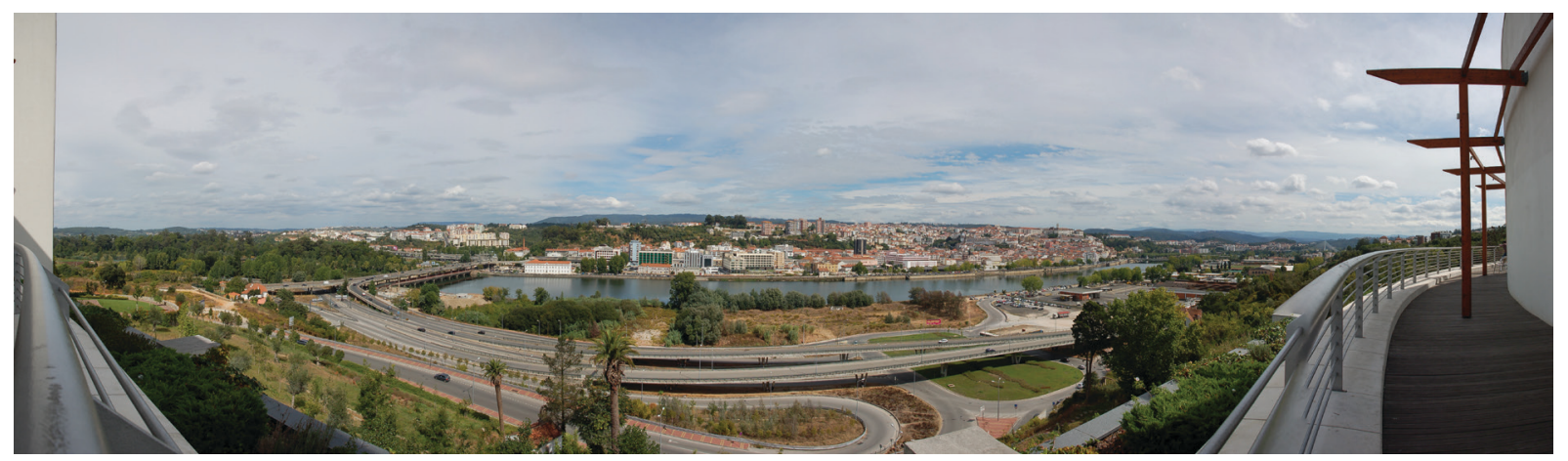

Toda esta área foi alvo de uma nova malha urbana, que se procurou articular com a da cidade existente na outra margem, ligando-as através de duas novas pontes pedonais. As cidades encontram-se finalmente sobre o rio, e este passa a ser parte da rede espacial que une programas e densifica atividades, reforçando a massa crítica indispensável para que tudo funcione, e para que o novo elétrico de superfície, em projeto, possa estender o seu alcance à margem esquerda, onde já vive uma percentagem muito elevada (cerca de $50 \%$ ) da população de Coimbra.

Sobre os muros da frente de água da margem direita, tradicional e central, os vazios da obsolescência ferroviária e industrial abrem oportunidades para o preenchimento de novos blocos residenciais, onde a hotelaria em instalação se integra no redesenho urbano, que as novas artérias transversais cruzam, ligando o miolo da Baixinha ao rio. Ao longo de uma nova avenida, paralela ao curso de água, estabelece se o corredor por onde vai fluir o novo transporte ligeiro sobre carris, que se quer ver também cruzar o rio, e estabelecer fluxos capazes de fundir as áreas urbanas, e fixar definitivamente a cidade nas duas margens, demolindo valores ambíguos de centralidade e periferia que já não fazem qualquer sentido. 


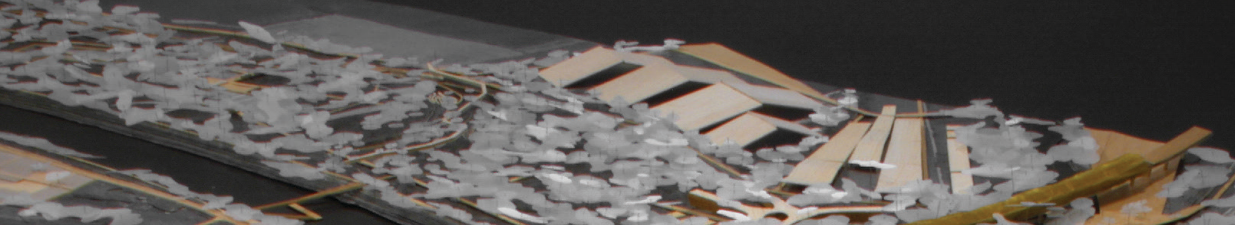

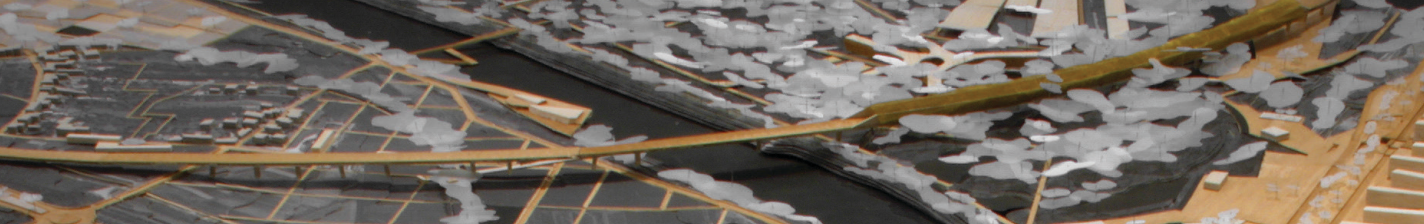

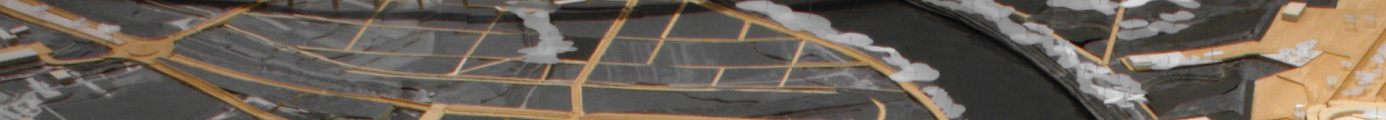

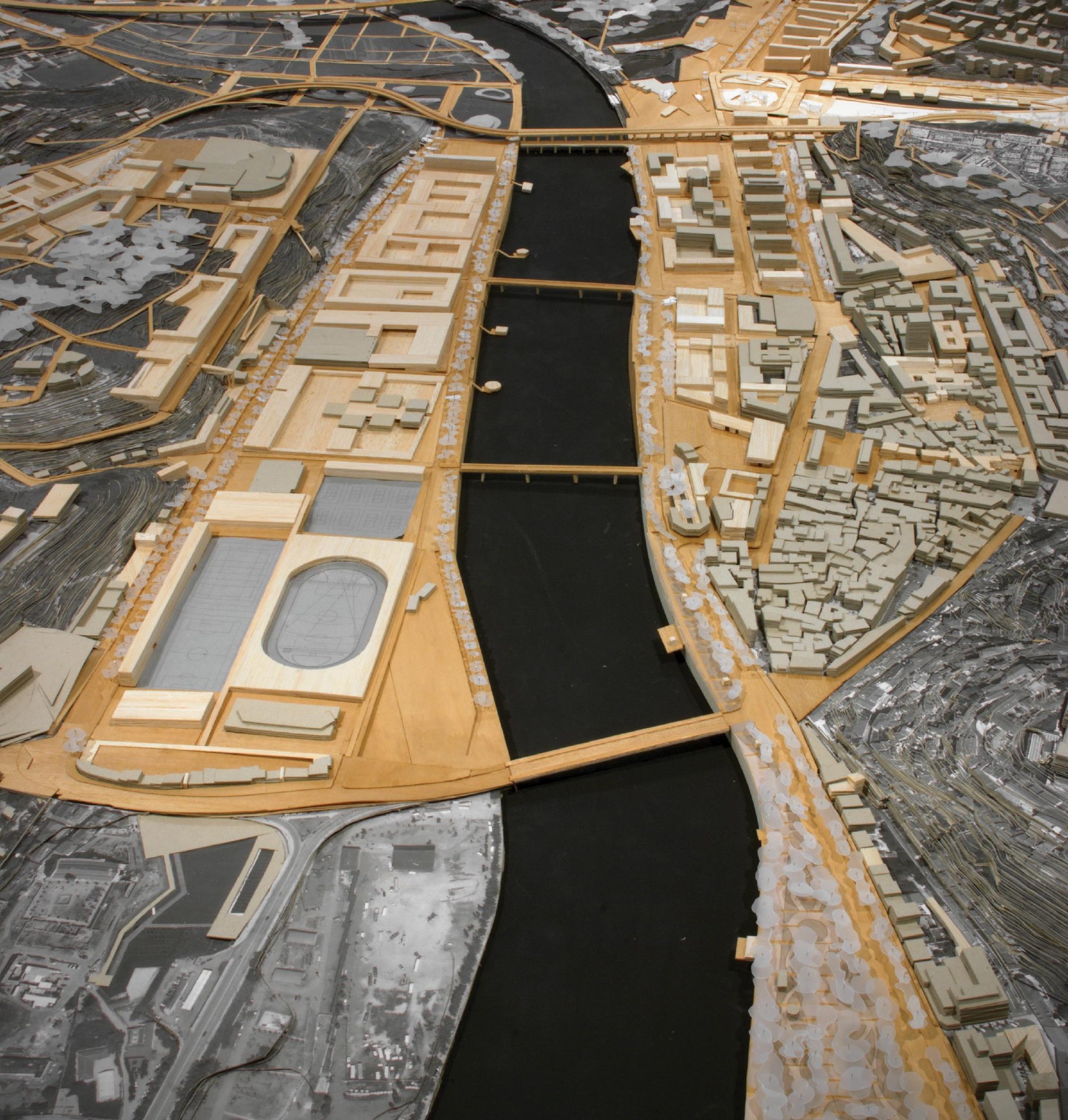



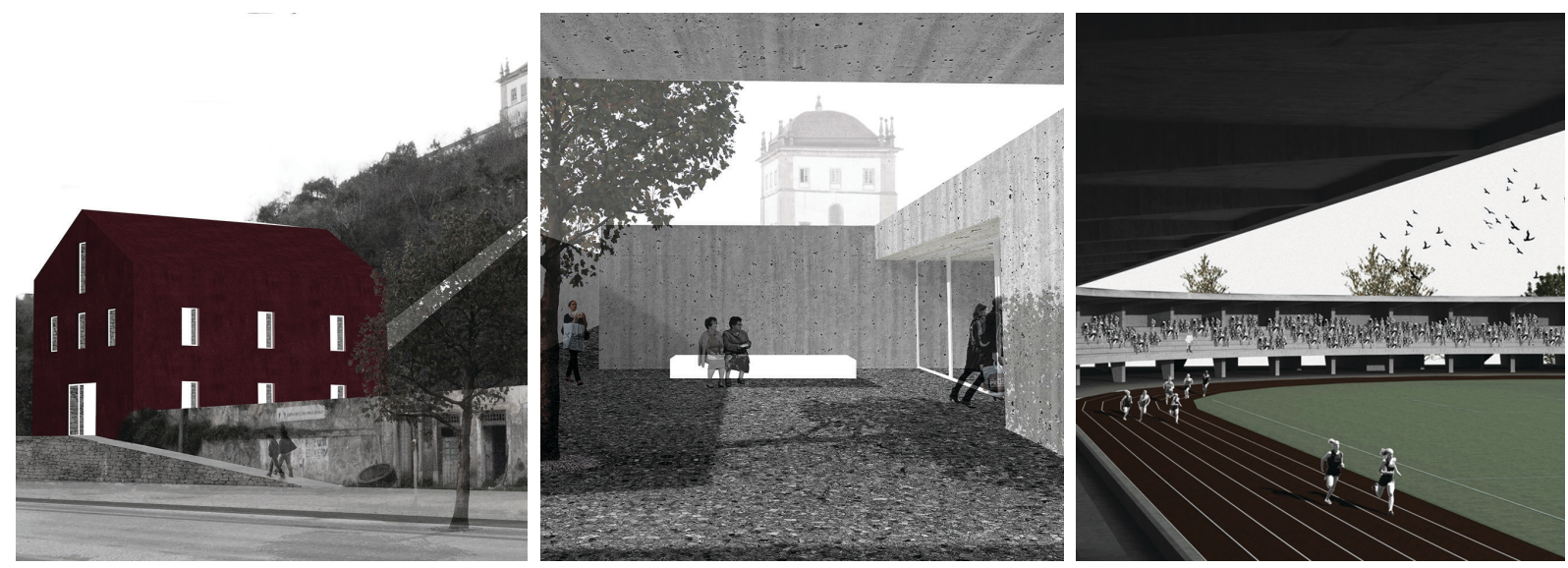

Um pouco mais a norte, a abertura da uma nova avenida de ligação à estação ferroviária projetada para a alta velocidade, é o pretexto ideal para o desenho de uma nova porta urbana, e um novo acesso à Mata do Choupal e às margens artificiais que a natureza colonizou, ao longo de mais e quarenta anos, renaturalizando os diques.

No seu conjunto, as margens encontram neste projeto um corredor fluvial que foi duplamente sublinhado por áreas predominantemente naturais, em diferentes cotas, numa sequência de parques que permitem percorrer toda a frente ribeirinha da cidade num desfiar de espaços ajardinados de excelência ou, alternativamente, em jardins públicos ou espaços densos que se arborizam, conjugando a rede verde já instalada com os novos espaços que o projeto desenha.

Esta nova realidade é justificada por um pertinente reforço e densificação das zonas residenciais envolventes, que assim se aproximam do rio, contrariando a tendência anterior de dispersão e periferização descontrolada em direção ao interland urbano. Ao mesmo tempo, os programas e aspirações que a urbe ambiciona instalar foram previstos e desenhados, como parte deste projeto visionário, que no âmbito académico ousa propor criativamente, para poder desafiar a gestão e agitar o debate e a participação cívica, em torno deste conjunto de importantes interrogações urbanísticas.

\section{Usos e percepções do Rio Mondego em Coimbra}

A requalificação já efetuada da frente de rio, com a construção do Parque Verde do Mondego e a regeneração de ambas as margens, de teor lúdico e recreativo, trouxe consigo novas possibilidades de usufruto para os cidadãos de Coimbra. Que perceções têm eles do rio e dos novos espaços edificados nas suas margens? Como o usam e se relacionam com ele?

O inquérito realizado junto de 272 residentes em quatro áreas da cidade, duas próximas dessa frente de rio - zona baixa de Santa Clara e Baixinha - e duas mais distantes - Conchada e Solum -, permitiu captar algumas ideias interessantes a esse respeito. Os resultados do inquérito mostraram uma forte valorização simbólica do rio, associada essencialmente a aspetos de natureza identitária, afetiva 

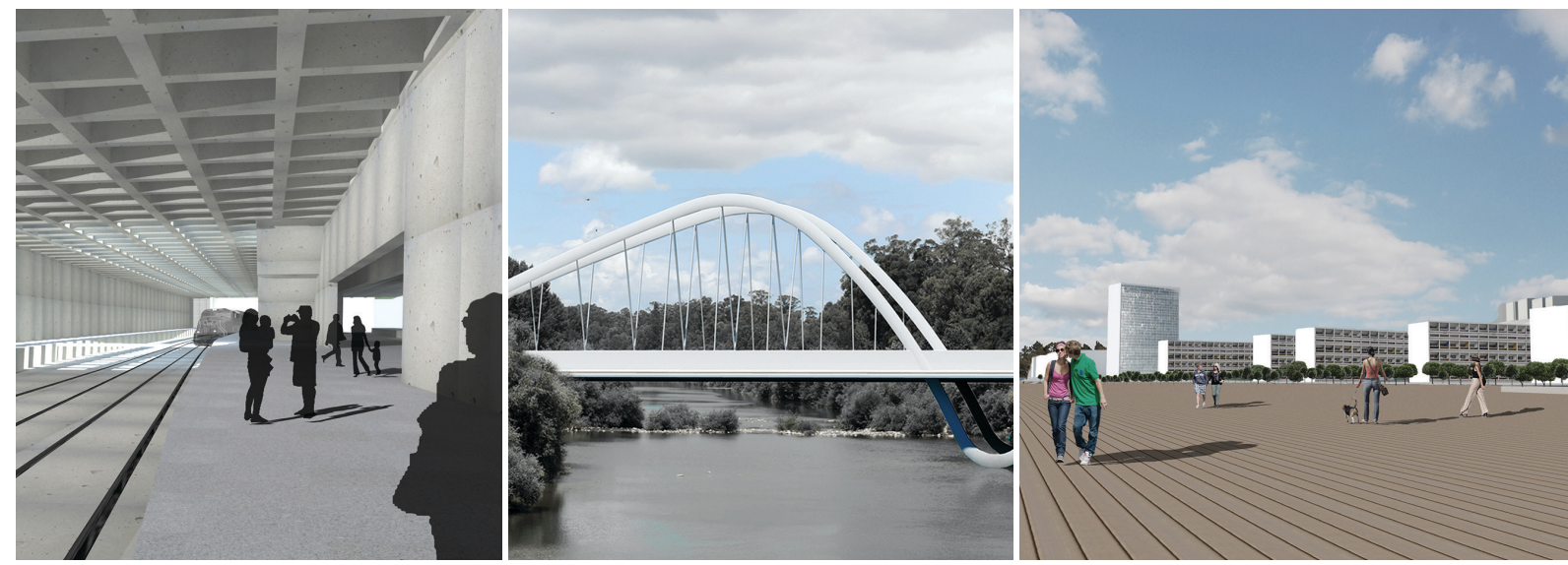

e lúdica. Confirmaram a persistência do rio como elemento central das narrativas e dos imaginários que construíram historicamente a identidade da cidade. Não obstante, essa valorização simbólica generalizada reflete modos de relacionamento e padrões de uso da frente ribeirinha bem diferenciados. Encontram-se na verdade diferenças nos tipos e intensidades de relação com o rio, que remetem quer para as distintas caraterísticas demográficas e sociais dos residentes das quatro zonas inquiridas, quer para os efeitos da proximidade ou distância geográfica ao rio.

No que respeita à regularidade e intensidade da frequência do Parque Verde do Mondego, é forte a influência da localização geográfica. Os residentes dos bairros mais próximos - zona baixa de Santa Clara e Baixinha - fazem uso mais frequente da frente ribeirinha. Essa distinção manifesta-se também na relação diferenciada com as duas margens do rio. A margem esquerda é muito menos frequentada pelos residentes dos bairros mais distantes - Solum e Conchada.

Quanto aos tipos de utilização da frente ribeirinha, são sobretudo os efeitos da condição social e do estilo de vida que se fazem sentir, aproximando os residentes dos bairros de Santa Clara e Solum, onde marca presença uma população mais escolarizada e típica das classes médias e superiores, em torno de usos mais lúdicos e desportivos, e de uma maior frequência de equipamentos e serviços como restaurantes, bares, desportos náuticos e atividades noturnas.

Os resultados da inquirição efetuada parecem confirmar a pertinência das apostas na valorização das margens, que se iniciou há muito e que os projetos agora desenhados desenvolvem de modo claro, olhando as oportunidades em aberto como exercícios de correção e estímulo de políticas urbanísticas

\section{Visões urbanas para a foz do Mondego}

O projeto para a frente de água fluvial, da cidade da Figueira da Foz, para além de alargar o diagnóstico de compreensão das problemáticas colocadas pela presença da água, com o inerente valor patrimonial e ambiental, respondeu a um desafio da Coordenação do Plano Estratégico para o município. Os estudantes da Escola de Arquitetura da Universidade de Coimbra investigaram e deram visibilidade a 
uma ousada estratégia de futuro, para a foz do Mondego, através de um conjunto de projetos urbanos, naturalmente sujeitos a algumas indeterminações programáticas. Contudo, os exercícios procuraram relacionar-se de modo realista com os complexos problemas detetados ao longo da fase de diagnóstico. Exploraram-se algumas possibilidades apontadas pelas equipas de planeamento municipais, nomeadamente: a possível transferência do Porto Comercial para as suas instalações logísticas na margem sul do Mondego, libertando grande parte da frente fluvial da cidade; a implementação da Agenda XXI Local e o programa de sustentação ambiental para o estuário do Mondego, e para a ilha da Murraceira; a potenciação do Cluster-Mar na região, valorizando a componente lúdica e turística, com a instalação de um terminal portuário de navios de cruzeiro, sobre a frente ribeirinha libertada na margem norte, e com a otimização das condições oferecidas pelas praias atlânticas, na Cova-Gala, na margem sul.
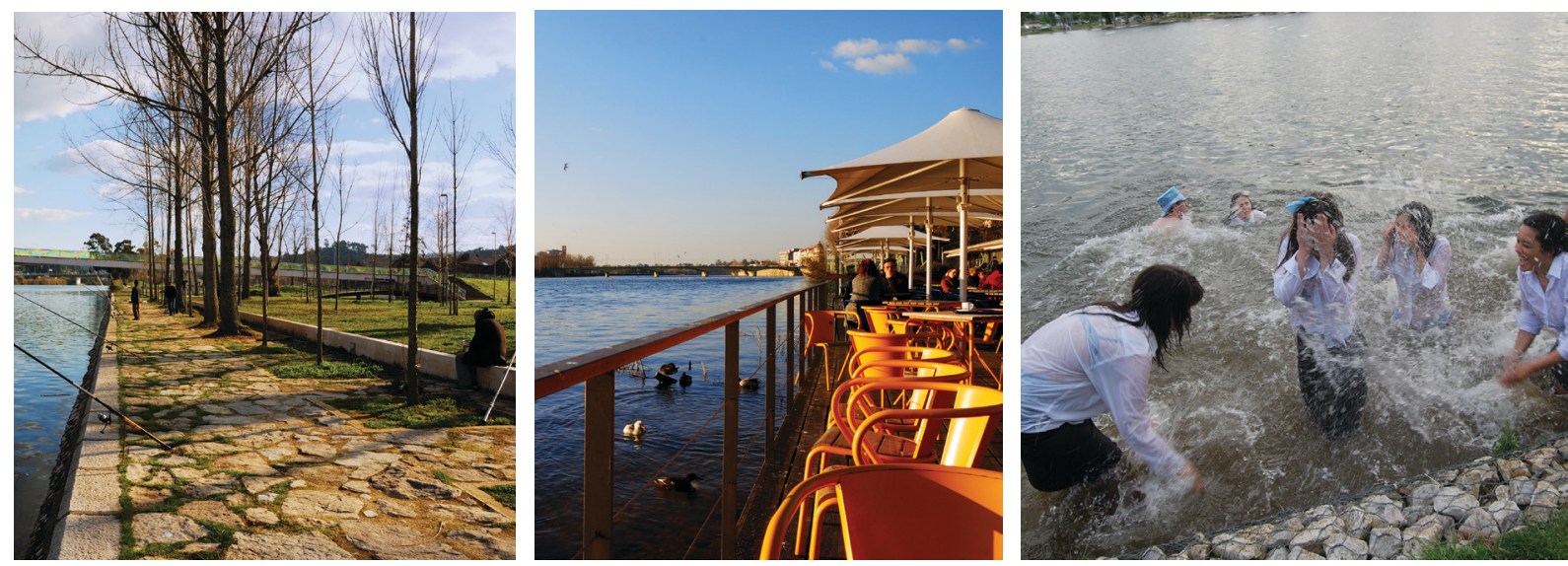

Estas possibilidades determinaram a identificação imediata de três áreas distintas de intervenção:

1. A frente urbana ribeirinha da Figueira da Foz, que ao beneficiar com a transferência do Porto Comercial se vai converter numa plataforma urbana aprazível, ajardinada, disponível para receber uma marina oceânica, uma marina de recreio e o já referido terminal de cruzeiros, com as respetivas áreas comerciais e de hotelaria. Ela constitui ainda o remate final de um longo percurso ciclável que percorre o corredor fluvial, entre Coimbra a Figueira da Foz, e que vai culminar por fim na dobra, sobre a praia atlântica, que espreita a outra frente de água da cidade, face ao oceano.

A transformação alarga o número de espaços públicos e equipamentos disponíveis - praças, esplanadas, jardins, ciclovias - permitindo a conexão entre a frente fluvial e os parques urbanos que, em penetração, vão desenhar os vales ajardinados das Abadias e de Tavarede.

A ligação entre as duas margens do rio, que é, na atualidade, exclusivamente rodoviária e difícil, passa a realizar-se agora através das duas novas pontes propostas. A primeira, pedonal, junto à frente marítima que se estende da cidade histórica até à Gala; a outra, ferroviária, articula-se com um novo interface rodoferroviário, que substitui a velha estação de caminho de ferro.

2. A Ilha da Murraceira, uma fascinante paisagem artificializada pelo labor de salineiros e marnotos ao longo de séculos, e refém de uma envelhecida estrutura de produção de sal economicamente 
debilitada, recebe novos percursos de ligação às margens envolventes. Mantem-se aí uma acessibilidade rodoviária estruturante, mas condicionada, de acesso laboral a este ecossistema sensível, enquanto o projeto privilegia os percursos pedonais e clicáveis. Trata-se de instalar um circuito de exploração e descoberta das antigas e revitalizadas atividades produtivas - o sal, as algas marinhas, a agricultura biológica, a aquacultura de peixe e marisco - e ainda, de uma incomum biodiversidade. Tira-se partido das inúmeras estruturas pré existentes - um velho e raro moinho de marés, comportas e caldeiras, palheiros e armazéns, viveiros de peixe e marinhas - e acrescentam-se equipamentos que reinventam a paisagem natural do estuário enquanto centro de acolhimento e interpretação. Instalam-se capacidades para a investigação científica, áreas museológicas e recreativas, apoios para a observação de aves, e diversos serviços turísticos ligeiros, que funcionarão de forma integrada e gerida por um
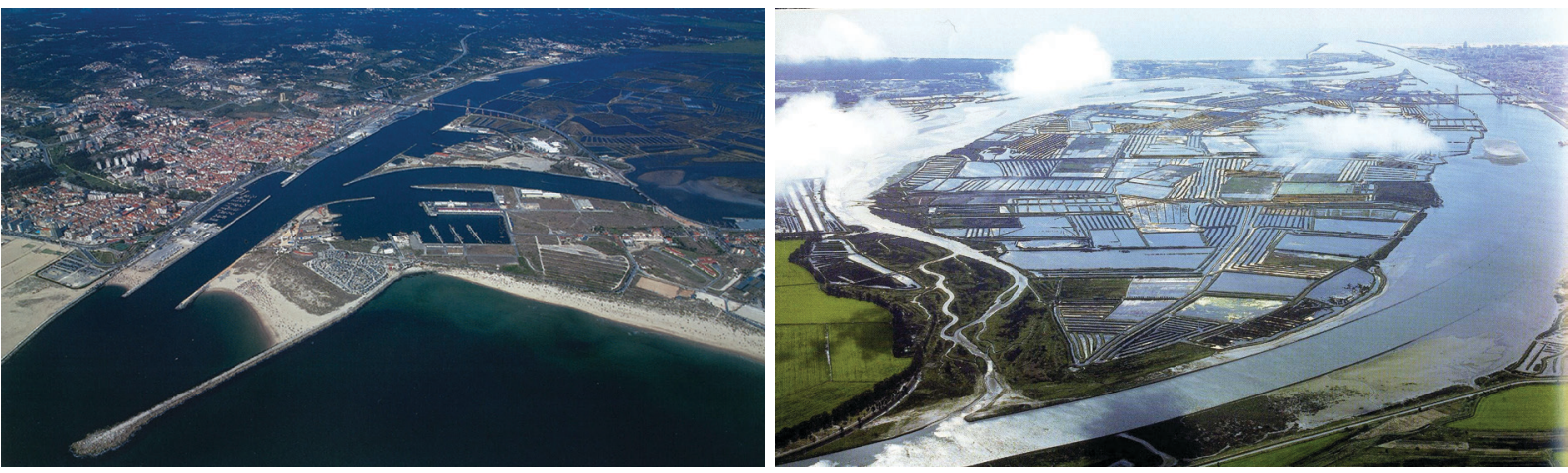

programa, já esboçado em plano diretor especializado, desenvolvido pelo município, para uma prática ambientalmente amigável. Na verdade, trata-se de espacializar as condições para a aposta na criação de uma "marca" própria, e para a revitalização de uma estrutura produtiva especializada, em sal e agricultura biológica, em regime de complementaridade, certificada e alargada a produtos derivados muito variados. Pretende-se revitalizar este amplo território estuarino de modo sustentável e alavancar modos de produção, agora cientificamente apoiados, de bens regionais de origem controlada e elevado valor acrescentado, fixando condições laborais adequadas e profissionalizando e especializando o trabalho. Também a aquacultura, atualmente em expansão, fará parte deste processo, mas sob vigilância apertada, para assegurar a salvaguarda ambiental dos biótopos e habitats, salvaguardando a qualidade deste excecional Sítio Ramsar.

3. A frente fluvial e marítima da Cova-Gala recebe o novo Porto Comercial, na margem sul do Mondego, em articulação com o Porto de Pesca, que é também ali reinstalado. Estes dois terminais serão a mão de um novo braço infraestrutural rodo e ferroviário, que redesenha o atravessamento da estrada nacional na Gala, agora assumida como a porta sul da cidade da Figueira da Foz. Os Portos Comercial e Piscatório definem uma nova plataforma logística que se relaciona com a zona industrial de Lavos.

Sob a frente portuária e marítima, que recebe a nova ponte pedonal, articulam-se extensos passeios fluviais e espaços públicos equipados. Na transição entre a frente de rio e o mar instala-se a nova Aldeia do Surf, enquanto os percursos se estendem ao longo de um deck elevado, sobre as dunas da praia. 


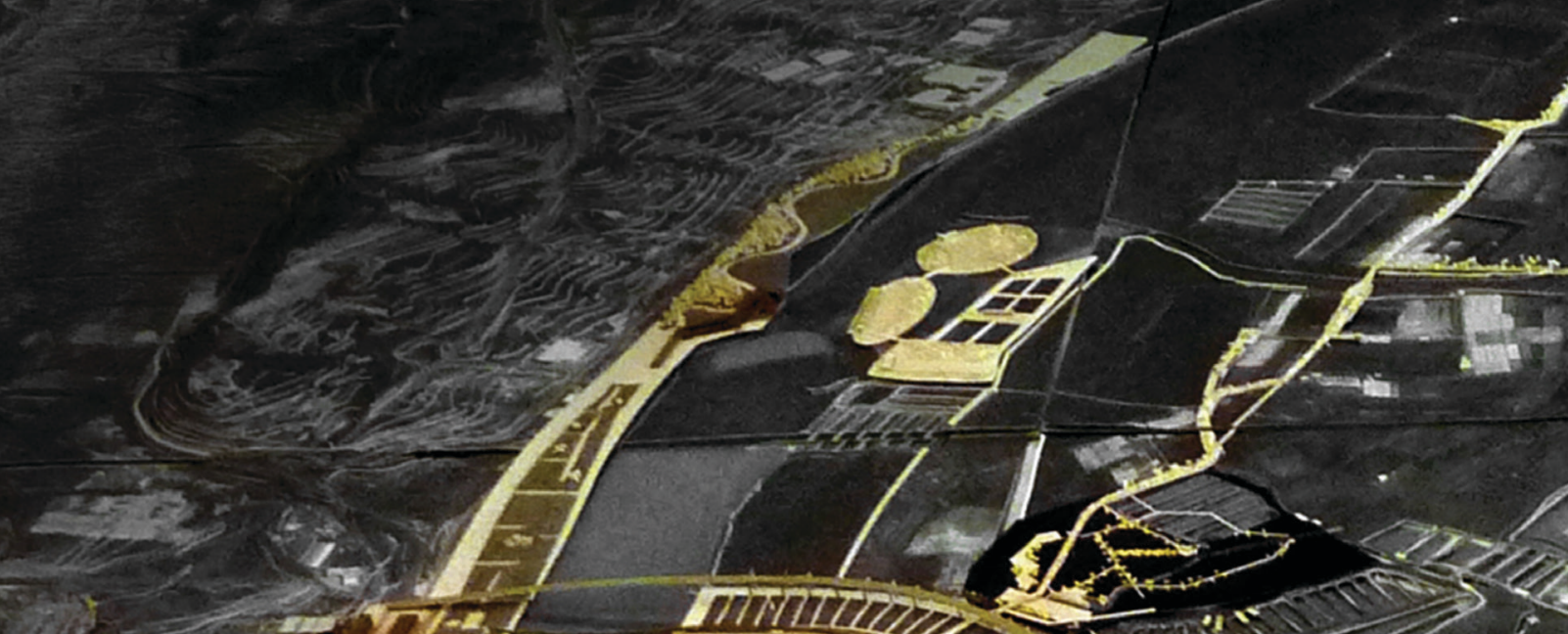

son $\rightarrow$ -

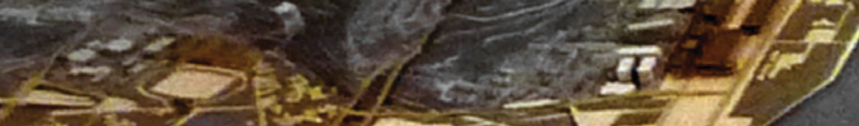

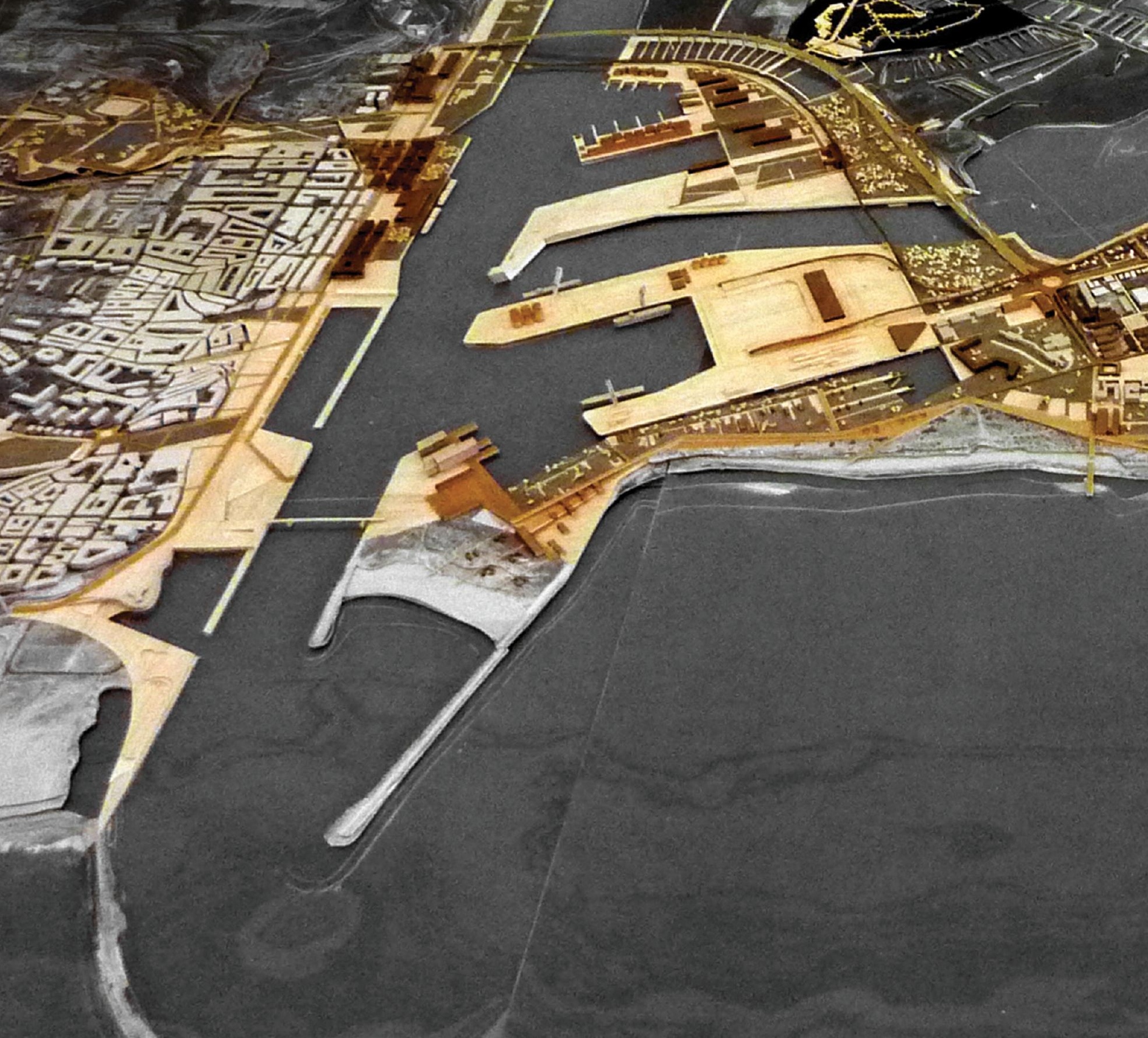




\section{Bibliografia}

Corboz, André (2001), Le terRItoire comme palimpseste et autres essals. Besançon: Les Éditions de L'Imprimeur.

Olaio, António (2012), Closing text from de catalogue of the exhibition The Flying River, Coimbra.

Augé, Marc (1992), Non lieux, Introdution à une antropologie de la surmodernité. Paris: Le Seuil.

Solá Morales, ignasi de (1996), Presente Y Futuros, Arquitectura en las ciudades. Barcelona: CCC.

\section{Agradecimentos:}

Arquivo Histórico Municipal de CoImbra;

Filipe Jorge e Instituto Geográfico do EXÉrcito (Fotos aÉreas);

Daniel Pinheiro (molduras do documentário "Mondego", 2011 - htTP://VImeo.com/31170389);

TAMBÉm AOS AUTORES, CONHECIDOS E/OU DESCONHECIDOS, QUE TORNARAM POSSÍVEL A INCLUSÃO DE IMAGENS MAIS ANTIGAS, ASSIM COMO DE IMAGENS ATUAIS, PERMITINDO O RECONHECIMENTO E A IDENTIFICAÇÃO DOS TERRITÓRIOS ESTUDADOS. 


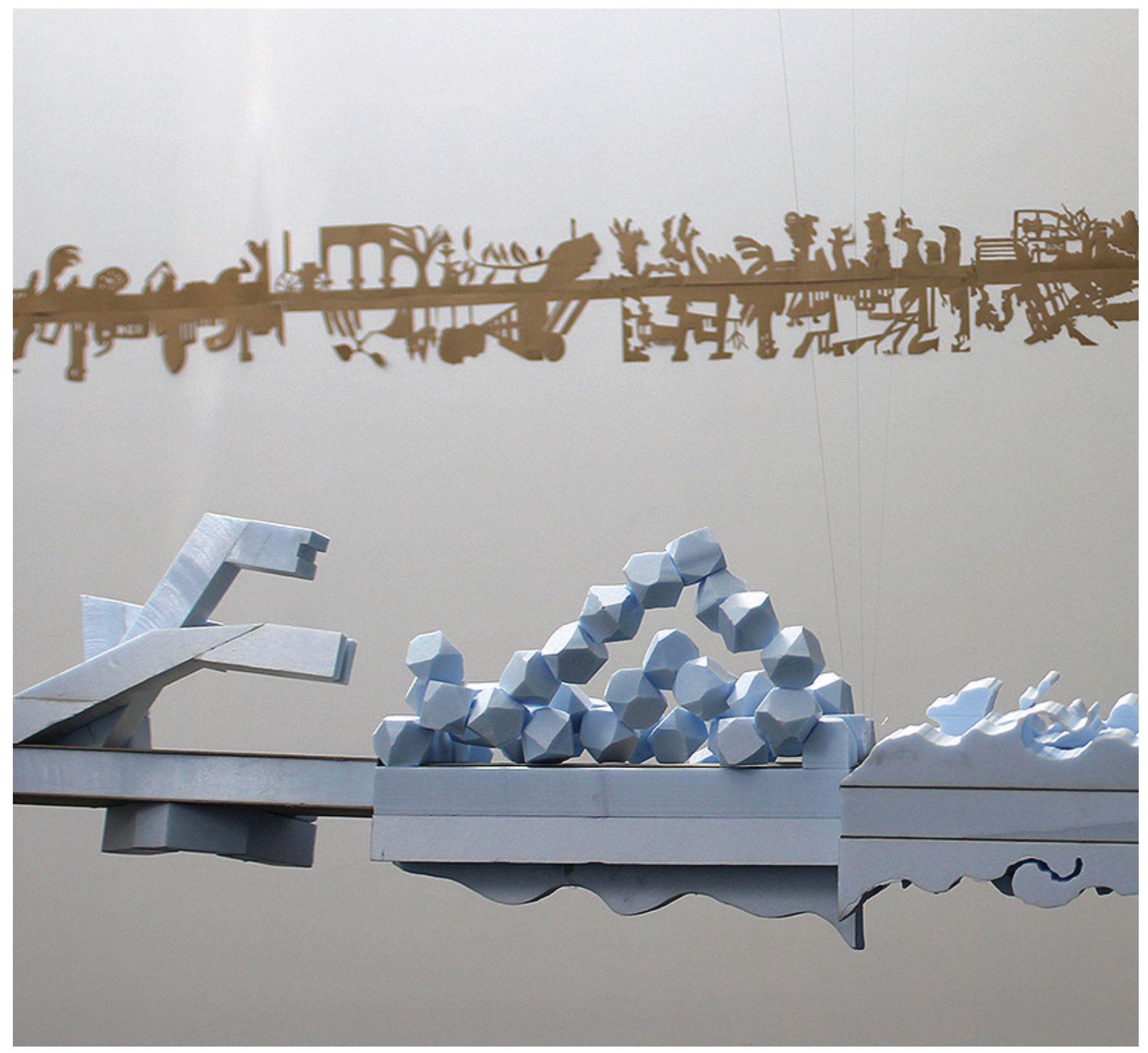




\section{O Rio Voador}

Não há rios que não sejam voadores, como aliás quaisquer conceitos. Mas, aqui, a evocação do rio faz-nos lembrar que ele divide a cidade em duas, com ele a cidade passa a ser duas, um lugar que é pelo menos dois. Por outro lado, provocando um intervalo na cidade, o rio pode ser encarado como uma espécie de suspensão da realidade. E, como todos sabemos, corre para outros lados...

Nesta capacidade de abstração que a experiência de um rio potencia, esbatendo os contornos de um lugar físico ou mental, um rio é sobretudo uma experiência estética.

Para esta exposição os artistas foram convidados a participar com obras que partissem da ideia de "rio voador". Ou, melhor, foram colocados perante o facto de a exposição se chamar "O Rio Voador", apresentando obras que habitassem este contexto.

Assim, as peças aqui expostas, sendo explícita ou não a ideia de rio, usando a imagem do rio nas potencialidades metafóricas de um rio, situam-se sobretudo num universo que a possibilidade de um rio voador abre.

António Olaio

(Texto de abertura do Catálogo da Exposição "O Rio Voador". Coimbra, CAPC, 2012). Catálogo integral disponível em http://www.ces.uc.pt/epat/pages/pt/eventos/o-rio-voador.php 


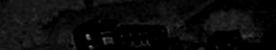

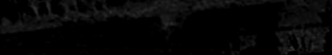

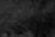




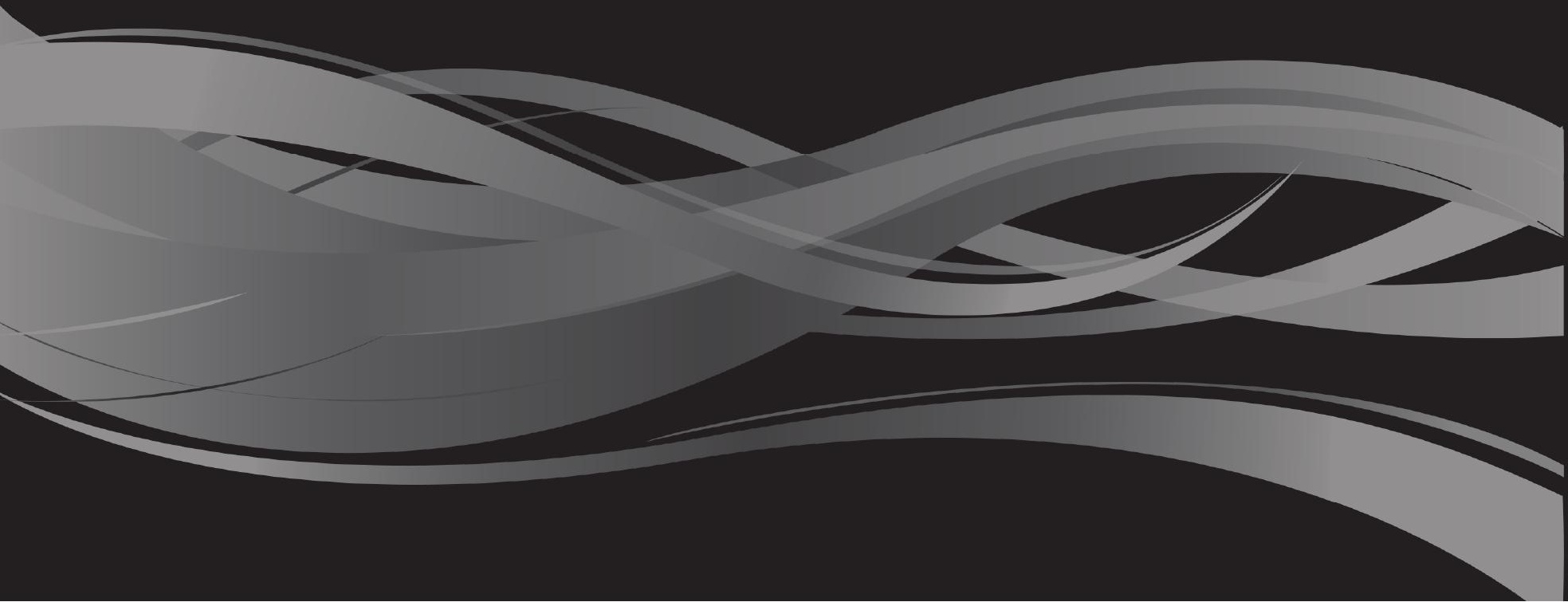


O presente plano diretor pretende resumir e ilustrar um projeto amplo, que permita um imediato e compreensivo olhar sobre toda a área de estudo trabalhada durante o ateliê de projeto do programa europeu "Água como património": este plano funciona, no âmbito do projeto, como aferidor das questões metodológicas definidas pelo grupo de trabalho, inerentes às modalidades de gestão do sistema das águas, em função dos elementos de requalificação do território de Comacchio.

O objetivo que levou a este Programa foi, de facto, o de fornecer um contributo ativo para a redescoberta da importância dos rios e paisagens de água em estratégias de revitalização turística e económica, além da requalificação e valorização urbana e paisagística do território. Esta intenção decorre da extrema riqueza antropológica que estas áreas sempre tiveram na história da civilização humana, tornando esses territórios quase sempre elementos estruturantes que possibilitavam a evolução económica e social das populações aí instaladas.

O âmbito escolhido pelo grupo de trabalho local representou um estudo de caso de extremo interesse, sendo uma paisagem desde sempre configurada e transformada pelos sistemas de controlo, regulamento e aproveitamento das águas. Só a partir do segundo pós-guerra esta simbiose entre artificialização e sistema de águas foi sendo progressivamente reduzida, com efeitos negativos para o atual quadro territorial: poucos recursos hídricos, urbanização descontrolada, depressão económica, inundações, tráfego elevado e degradação.

O passado deixou, no entanto, numerosos testemunhos. Alguns são, atualmente, património histórico e museológico, enquanto outros, ainda "em uso", permitiriam, se adequadamente valorizados, percorrer a génese e as modificações do território em que estão inseridos. O Programa Europeu "Água como património" propõe e estuda um possível cenário: assumir o sistema das águas, um complexo somatório de ambientes e infra-estruturas, em alguns casos sugeridos como hipóteses futuras para desenvolver novamente uma função de estrutura no palimpsesto territorial, de modo a fornecer uma nova estrutura, ordem e renovado valor à paisagem local, contribuindo, ao mesmo tempo, para reduzir ou sanar os problemas supramencionados, que
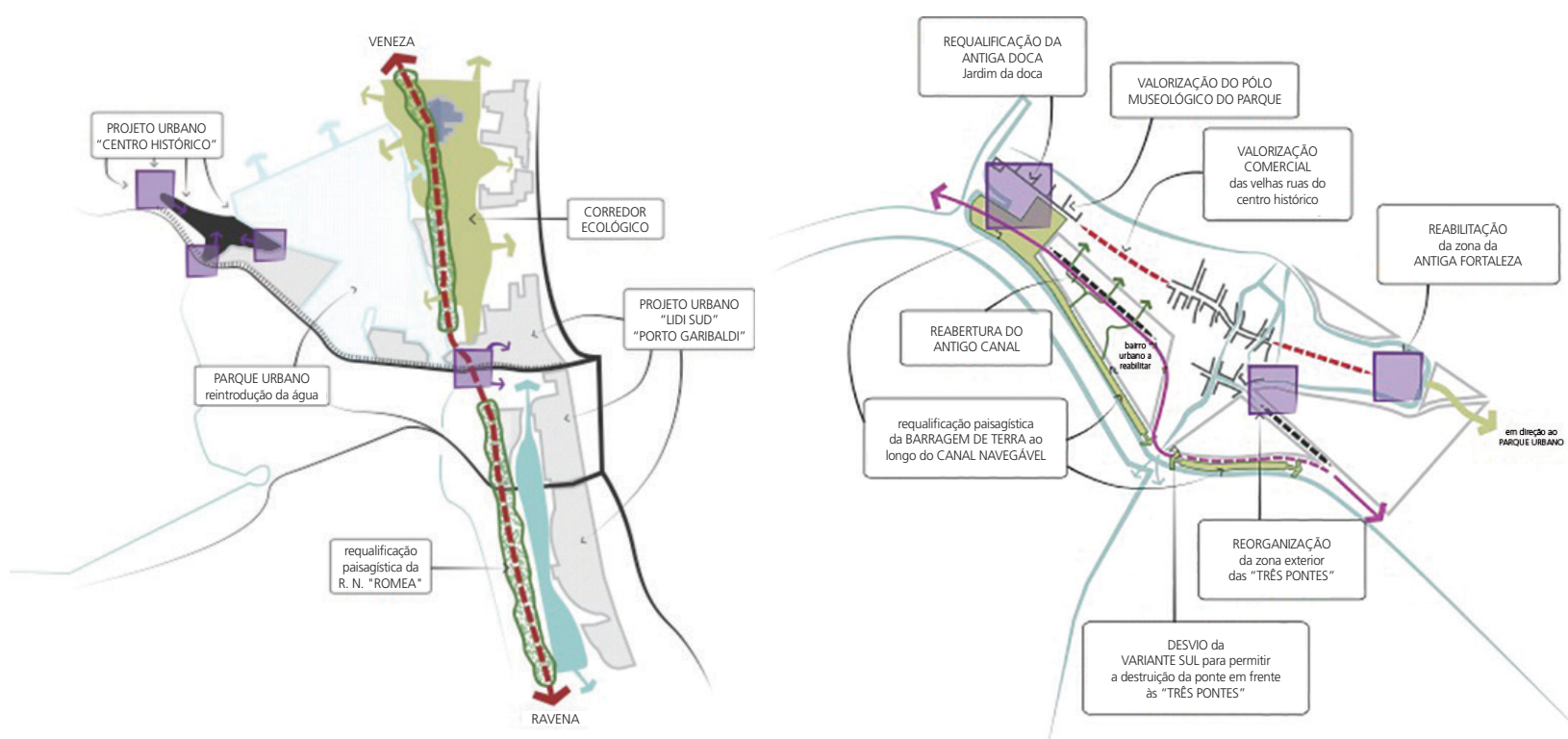



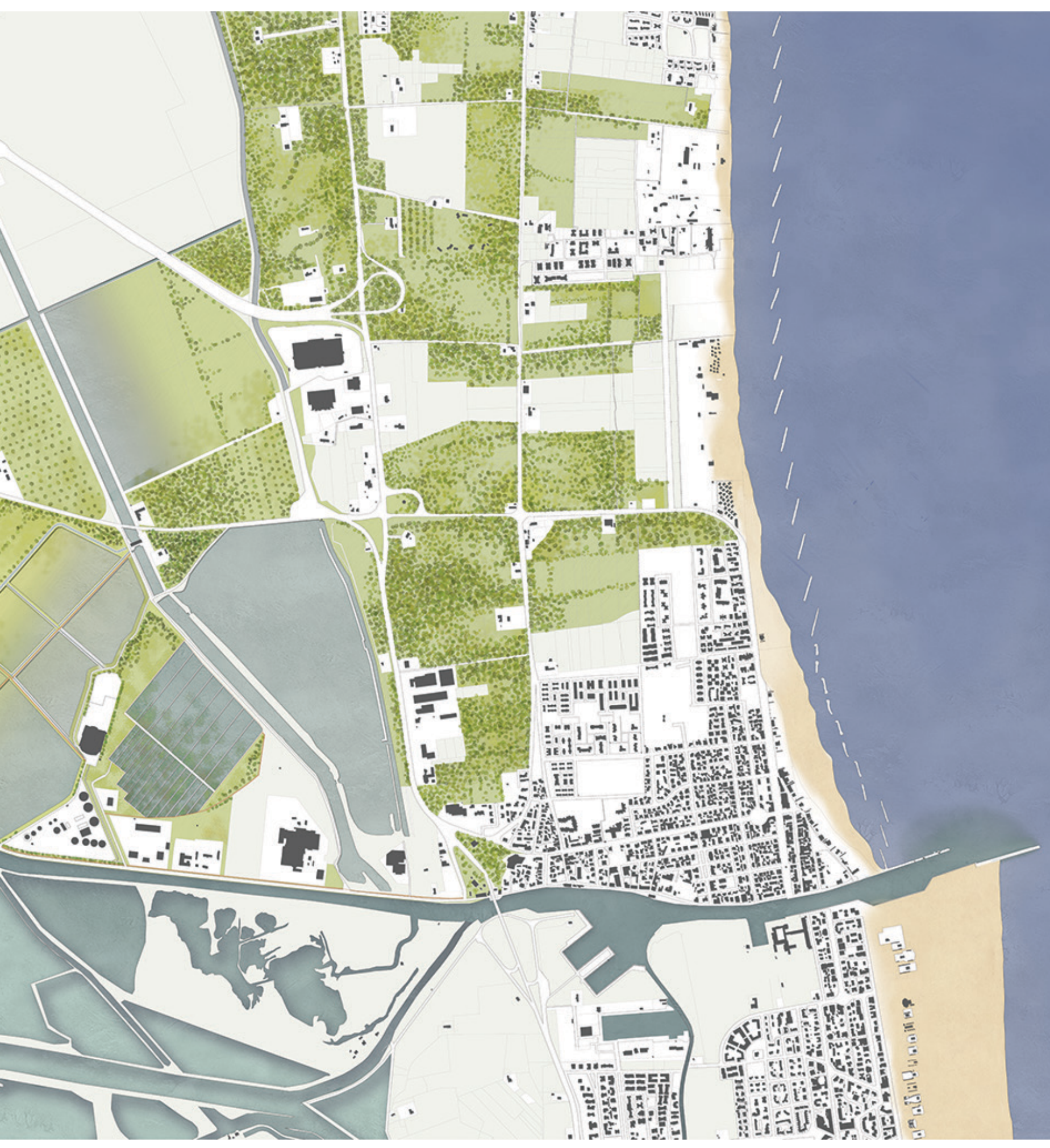


afetam esse contexto. No decurso da fase de projeto deu-se particular atenção à capacidade que os rios e as paisagens de água podem ter de se tornarem espaços públicos, quer no interior dos núcleos urbanizados, quer como elementos de valor ecológico e ambiental quando situados em território rural.

Os êxitos finais do Programa Europeu "Água como património", resumidos no presente texto, pretendem ser um conjunto de "boas práticas" em matéria de planificação urbanística e territorial que, também através de algumas prefigurações de projeto fornecidas como soluções plausíveis para determinadas problemáticas, visam propor uma mudança substancial de direção, em matéria de escolhas de planificação, baseada na necessidade de voltar a partir do elemento fundamental do território local: a água enquanto novo "padrão urbanístico", ou seja, dotada de um grau de obrigatoriedade em cada escolha que comporte uma transformação do território. Uma água capaz de assumir uma pluralidade de funções baseada nas diferentes necessidades: espaço público, infra-estrutura para mobilidade, mecanismo de controlo hídrico, âmbito produtivo, elemento de valor ambiental e componente da paisagem. O Programa Europeu "Água como património" propõe, portanto, o retorno a um uso consciente do sistema das águas como possível alternativa ou contributo para as atuais práticas urbanísticas, as quais demonstraram a incapacidade de poder governar com eficácia e eficiência um território extremamente complexo e contraditório, como é o caso do litoral de Comacchio.

\section{Área ex Eridania}

Propõe-se a requalificação da antiga zona industrial, atualmente desativada e à espera de uma futura reativação, que possa servir as infra-estruturas de transporte de acesso à cidade. Atualmente, é apenas possível chegar a Comacchio através das vias rodoviárias, através de autocarro ou meio de transporte próprio; pelo contrário, propõe-se articular essas modalidades com o apoio, com fins turísticos,

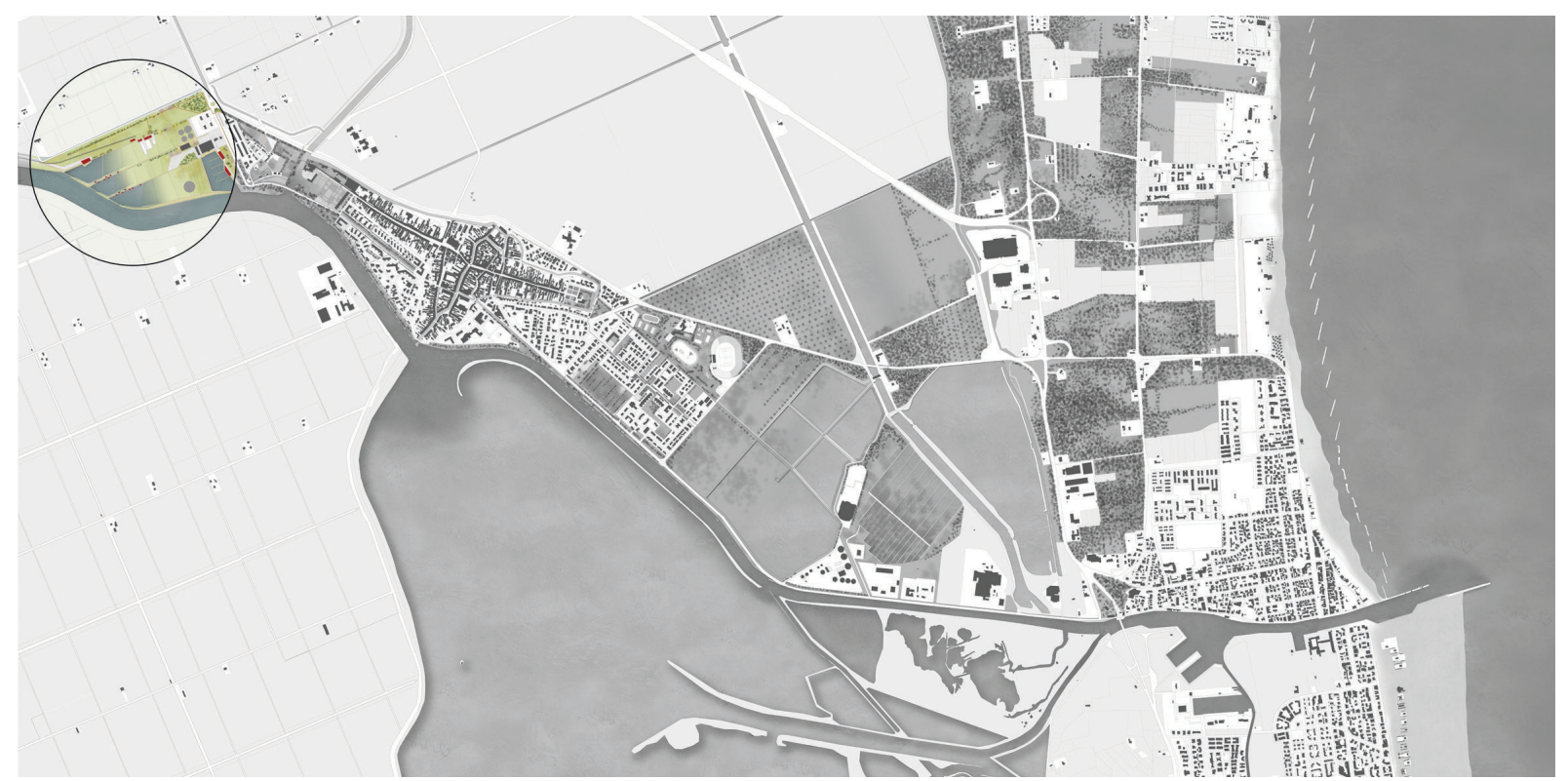


da via fluvial de Ferrara, atualmente objeto de uma importante requalificação, que poderia tornar-se via prioritária de ligação entre o interior, Ferrara e a costa, e através do restabelecimento da linha ferroviária entre Comacchio e Ostellato, destruída durante a segunda guerra mundial. A área da antiga refinaria de açúcar torna-se, na presente proposta, centro dessas renovadas infra-estruturas de ligação, acolhendo os seguintes elementos: estação ferroviária, terminal de autocarros e zona de abastecimento.

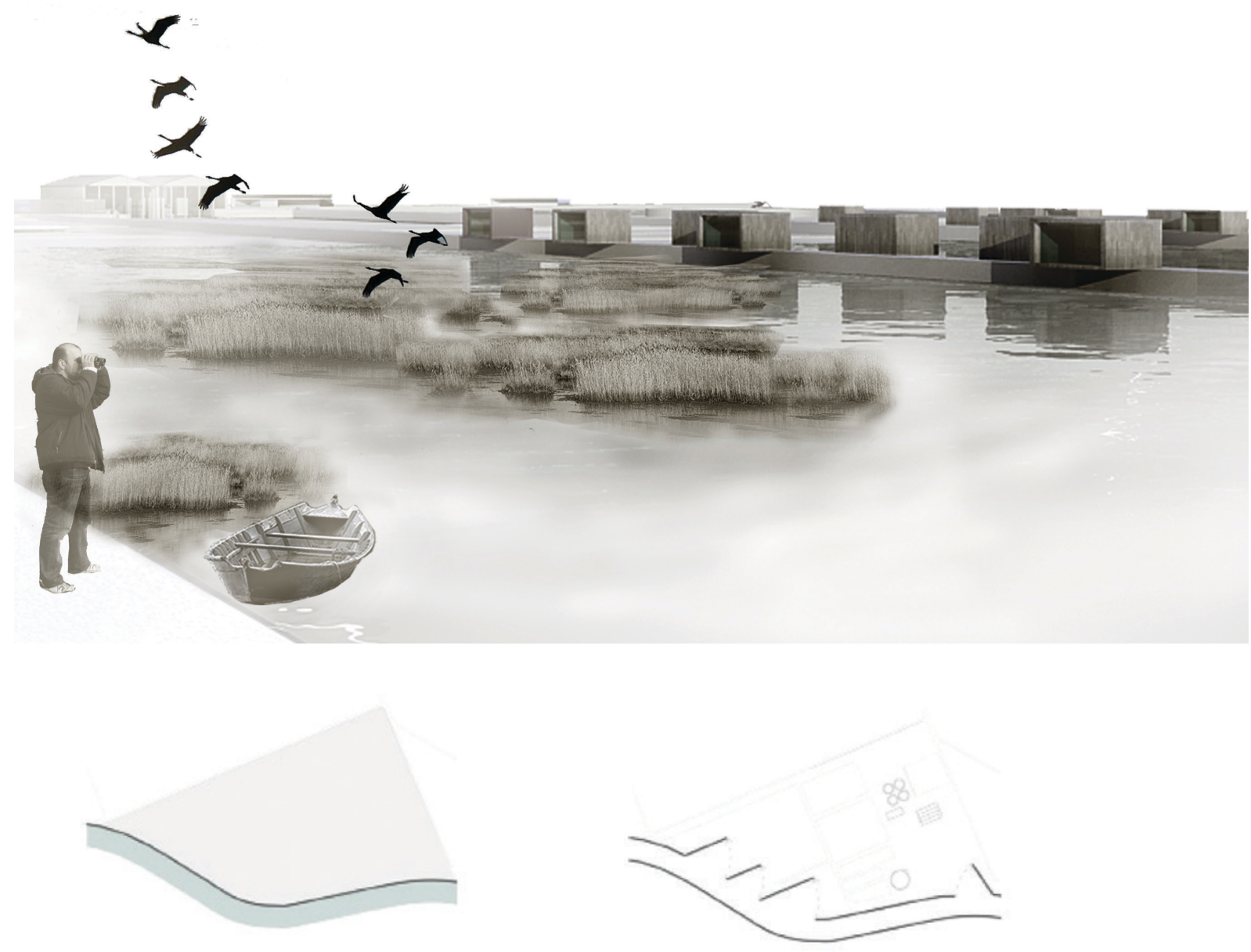

O banco de areia converte-se na interface entre a terra e a água

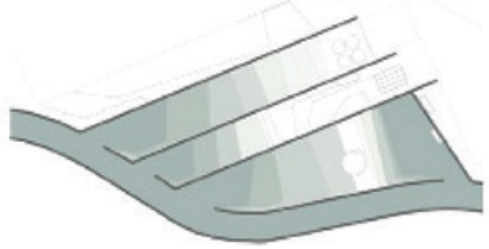

Rasga-se o banco de areia para fazer entrar a água na área intervencionada
Intervem-e nas margens para iniciar uma transformação da paisagem

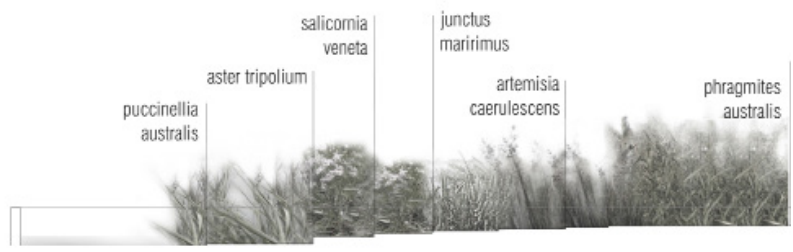

Vegetação espontânea 
Prevê-se também a inclusão dos seguintes serviços: bar, restaurante, hotel e pousada, centro de informações para turistas, aluguer de bicicletas e barcos e serviço de ligação com o centro histórico. O projeto propõe depois uma redefinição das áreas mais relevantes, na margem do Canal Navigabile, com o projeto de percursos pedonais na zona verde, a criação de repositórios para eventuais períodos de menos água e zonas de água para se plantarem essências vegetais hidrófilas, em que seja possível preservar os vestígios arqueológicos do antigo porto de Comacchio, presentes no subsolo.

\section{Villagio San Francesco}

Propõe-se a requalificação dos espaços abertos, existentes no interior e em redor do bairro, atualmente sem uma função definida, em parques públicos e hortos urbanos, de modo a conseguir uma melhor ligação entre o centro histórico e os subúrbios, os quais aparecem hoje como um elemento desassociado do restante núcleo citadino. Nestas novas zonas verdes colocam-se os traçados dos percursos ciclo-pedonais provenientes de Ex Eridania, garantindo uma ligação cómoda e segura com o centro histórico. Graças à redefinição dos espaços abertos, entre o bairro e Comacchio, obtém-se também a reconfiguração da margem ocidental do troço urbano do Canale Marozzo.

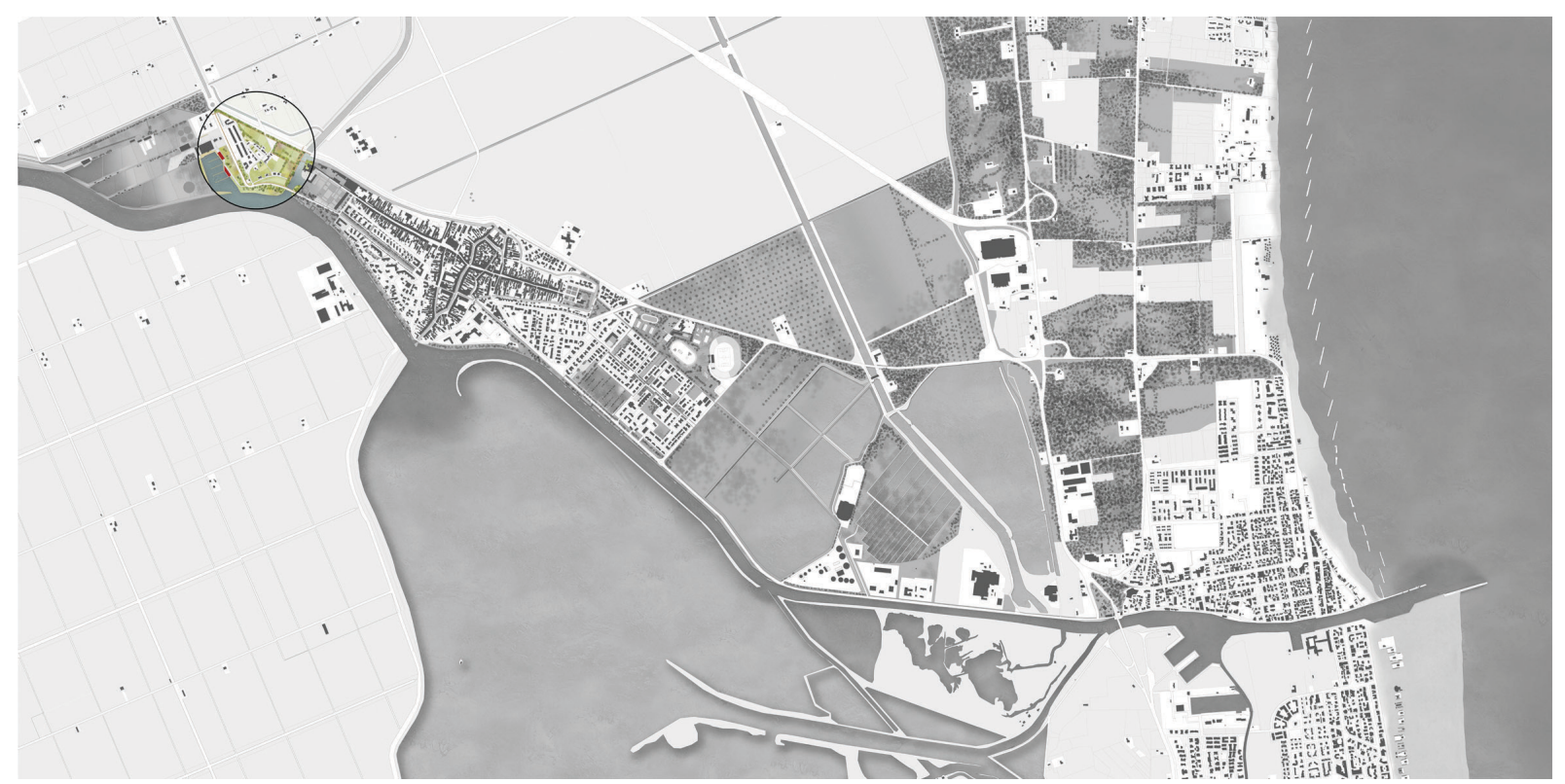

\section{Santa Maria em Aula Regia e o Pórtico dos Capuchinhos}

Propõe-se uma profunda transformação de toda a área, atualmente ocupada por alguns edifícios inutilizados, em parte propriedade pública. Esta situação torna possível a completa demolição, que está 
a ser pensada pela administração municipal, com vista a recuperar a antiga e plena visibilidade, do lado da via Spina, de todo o Pórtico dos Capuchinhos; pretende-se também deslocar mais para Este a via Valle San Carlo, para reabilitar toda a área e acabar com o tráfego rodoviário. O projeto propõe, portanto, transformar toda a área num parque, dotado dos devidos serviços, localizado dentro de uma volumetria em materiais ligeiros, com um prospeto altamente permeável, como uma margem entre o jardim e a cidade; este parque deverá ter amplas superfícies de água, com ligação hidráulica com as vizinhas docas turísticas, de modo a acrescentar valor percetivo ao local. Este novo espaço público poderá ser o palco principal de numerosos acontecimentos que se desenrolam anualmente em Comacchio. Com o objetivo de garantir, neste âmbito, uma vista sobre a via fluvial de Ferrara, coloca-se a hipótese da demolição do único edifício habitacional privado, construído entre a via Spina e o Canale Navigabile, e dos armazéns municipais vizinhos, que se encontram num evidente estado de degradação. O projeto sugere, por fim, a redefinição da vista sobre o canal, através da construção de pequenos espaços em madeira sobre a água.

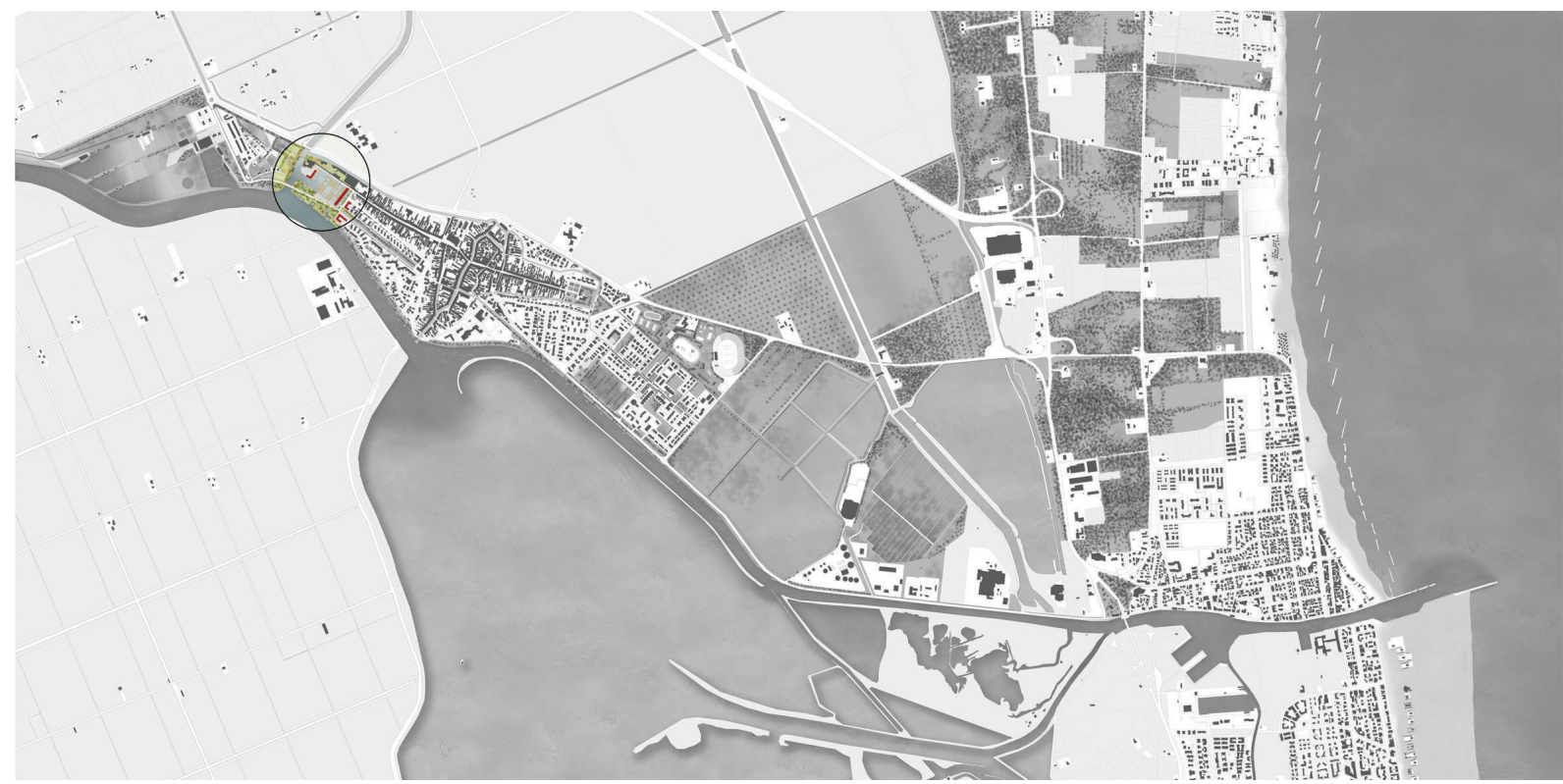

Propõe-se uma redefinição das áreas verdes no lado norte da via Spina, possível graças a uma racionalização dos parques de estacionamento aí existentes e à reabertura do Canale della Francesca, que se desloca atualmente no subsolo. O projeto avança também com algumas intervenções de "cirurgia urbana" no bairro de habitação social a sul da via Spina, com vista à requalificação do espaço verde do centro dos subúrbios, atualmente cercado pelo volume das garagens privadas: propõe-se a recolocação desses anexos, com o objetivo de recuperar o pleno usufruto do jardim público, que poderia assim tornar-se um espaço coletivo para todos os habitantes do bairro.

Serão inseridos também percursos ciclo-pedonais, transversais ao bairro, com ligação a norte com a via Spina e o centro histórico, e a sul com os diques do Canale Navigabile. Em relação a estes diques do canal, atualmente num estado de degradação e ocupado por volumetrias e funções impróprias, 
propõe-se a sua requalificação como espaço público com a inserção de um percurso ciclo-pedonal com pontos de paragem, com a plantação de arvoredos e com a subdivisão em parcelas dos espaços verdes existentes perto dos diques, destinados a hortos urbanos.

A margem do Canale Navigabile torna-se, graças a estas intervenções, um espaço público no cimo dos diques, permitindo a observação privilegiada dos vales vizinhos. Esta é uma estratégia de reaproximação, pelo menos percetiva, entre Comacchio e o seu território. Este percurso dá acesso e termina numa nova pequena praça sobre a água, na parte final da via Agatopisto, por baixo da ponte que atravessa o Canale Lombardo. É um ponto turístico em que se pode usufruir de uma renovada vista sobre os vales.
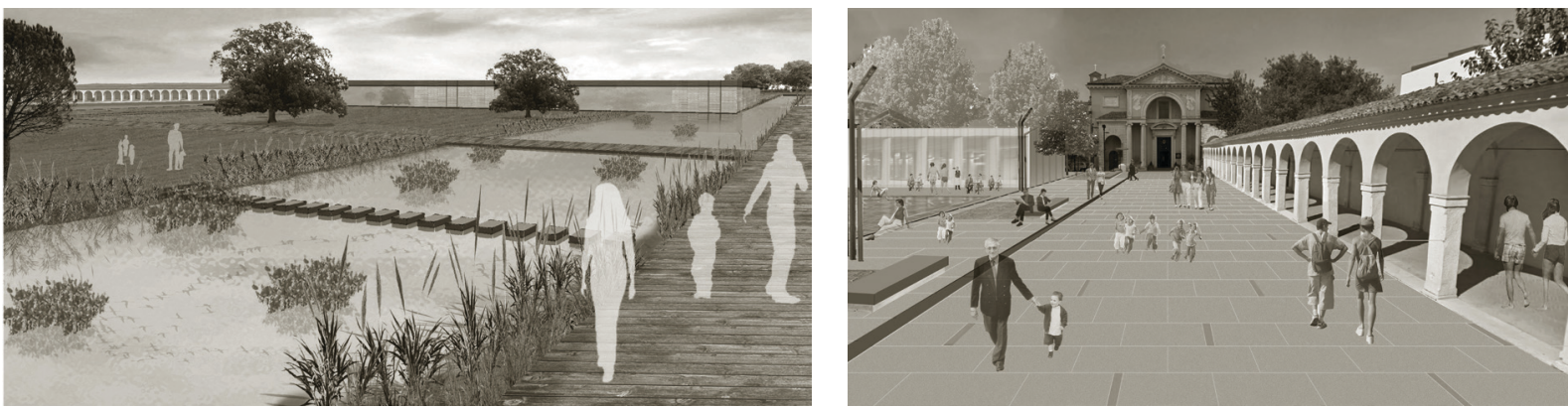

\section{Ex-convento de Sant'Agostino}

O projeto partilha a necessidade, expressa pela administração municipal, de iniciar urgentemente uma intervenção de restauro e requalificação de toda a área, que hoje se encontra num evidente estado de degradação física e estrutural, arriscando comprometer irremediavelmente as

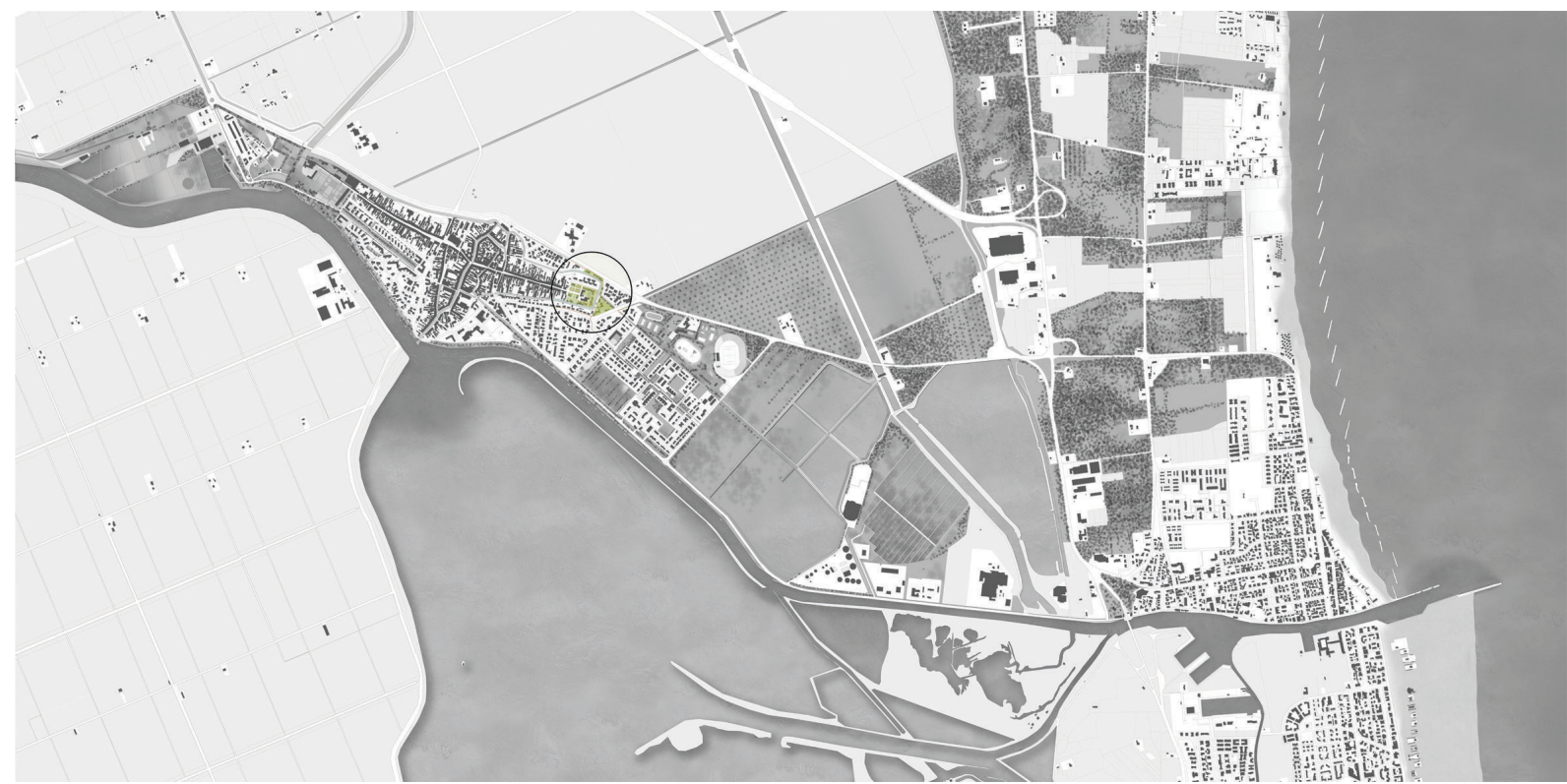


possibilidades de uma eventual recuperação. Propõe-se a redefinição dos espaços verdes adjacentes ao complexo e a inserção de funções públicas e coletivas, que possam dar ao local o estatuto de novo pólo atrativo que possa competir com os fluxos mais concentrados na parte do núcleo histórico, numa estratégia para uma revitalização, também comercial, do Corso Garibaldi. Esta obra torna-se, portanto, um ponto de ligação entre o centro histórico e as áreas periféricas a Este do centro habitacional, garantindo a permeabilidade dos percursos ciclo-pedonais referidos no presente projeto, que vão desde a parte histórica de Comacchio até ao Bairro Raibosola e ao "parque urbano".

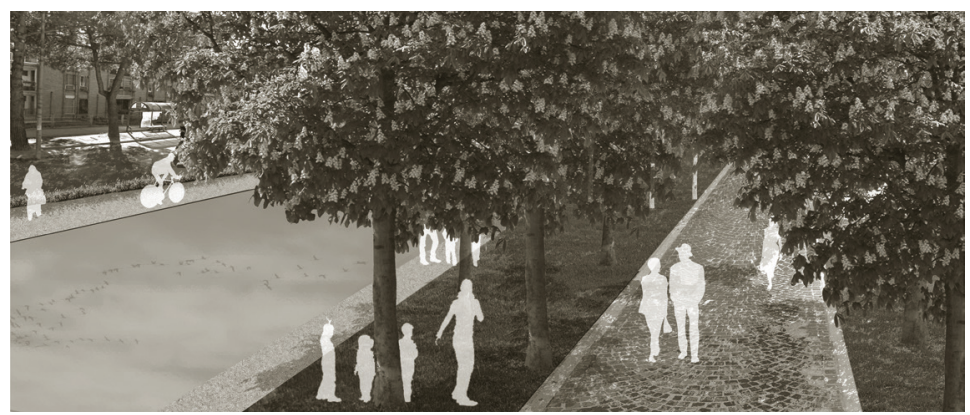

\section{Bairro Raibosola}

No interior do bairro "Raibosola" prevê-se a criação de uma série de percursos ciclo-pedonais, como ligação ao centro histórico e ao "parque urbano". O projeto sugere também a salvaguarda da zona verde na margem da via Marina, com a criação de um jardim público e uma espécie de horto

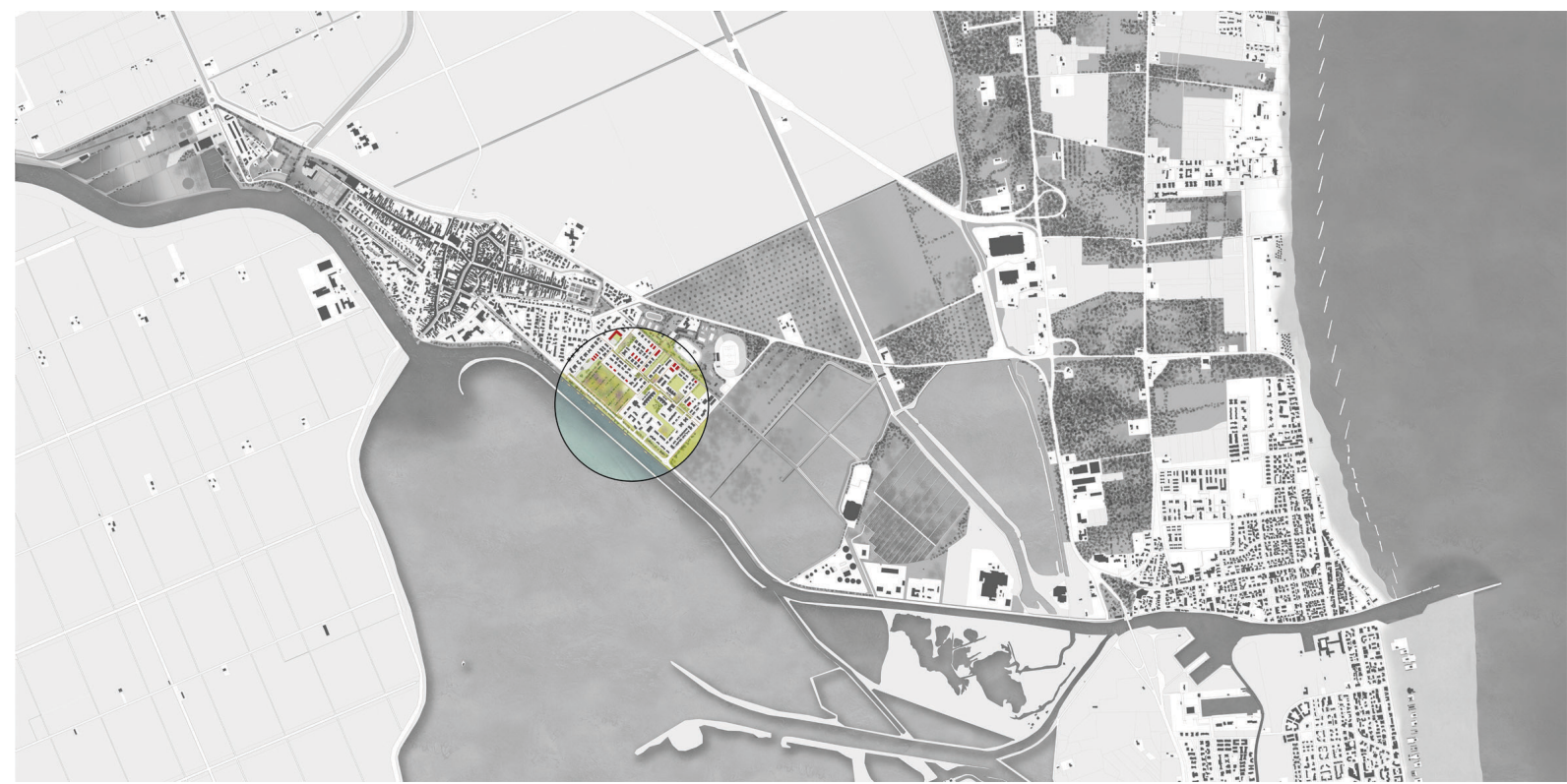


botânico dedicado às essências vegetais que vivem em terrenos com elevada salinidade, como aquelas que já existem no local. Em frente ao bairro propõe-se também a requalificação do dique do Canal Navigabile com a criação de um percurso ciclo-pedonal, dotado de espaços de paragem flutuantes, colocados sobre a via de água.

O projeto reconsidera o carácter das duas estradas paralelas que ligam Raibosola a Este e Oeste:

- a via Marina, que banha o canal a sul, será uma estrada panorâmica de médio tráfego;

- a via Gheraldi, que em direção a Oeste se torna via Pasolo, será fortemente desativada, tornando-se uma estrada quase pedonal e de acesso às residências que não podem ser servidas de outro modo. Será possível, portanto, pôr em relação os espaços abertos presentes em Raibosola.

Haverá mais uma via de comunicação com o centro de Comacchio, reabrindo o canal entre Raibosola e a futura cidade desportiva. O canal será ligado às vias de água que banham o ex-convento de S. Agostino, desempenhando a função de ligação de água entre o bairro, o convento renovado e o resto de Comacchio. Este canal estará também ao serviço da área desportiva aumentando, com os recursos da água, a oferta de atividades.

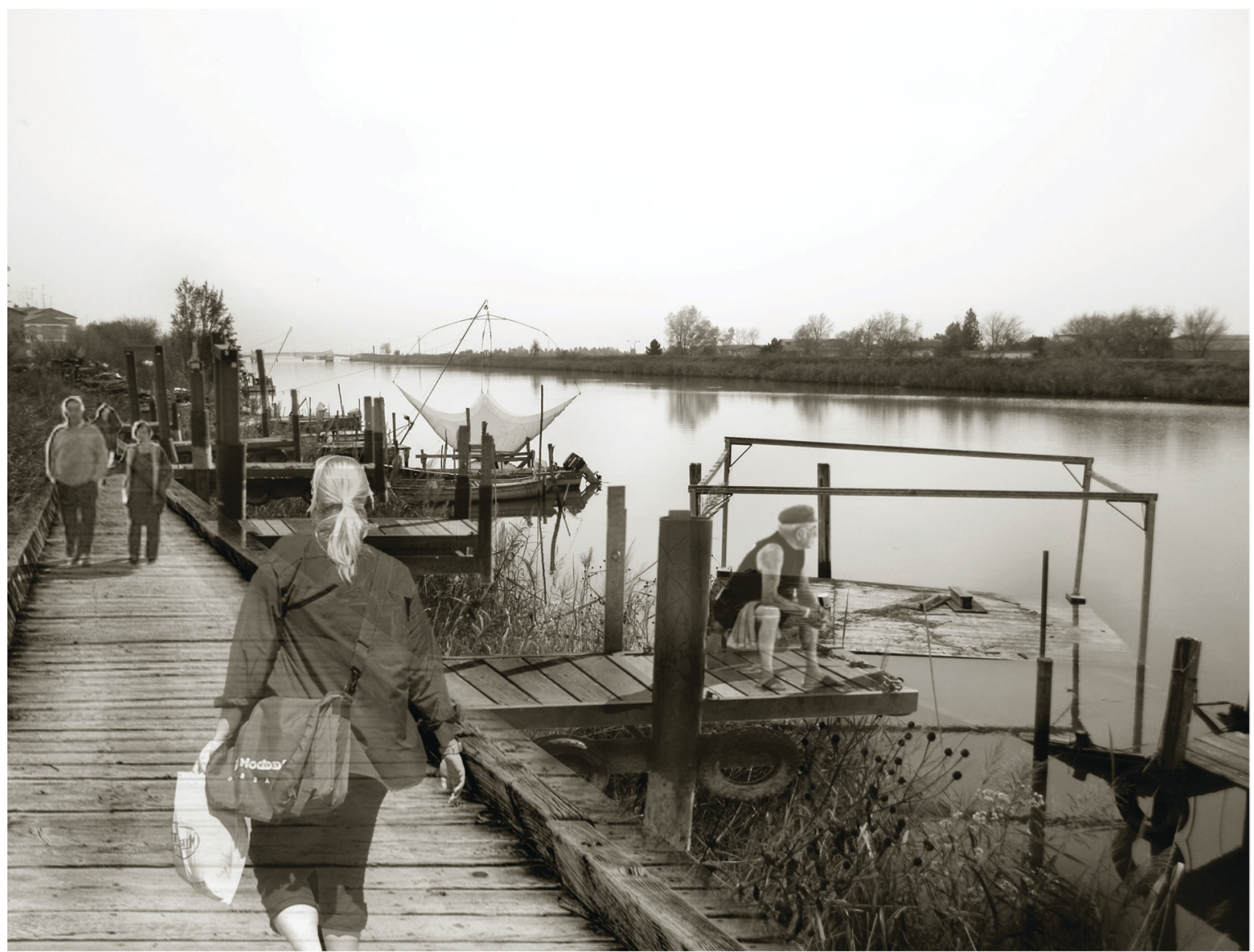




\section{Cidade desportiva}

O projeto prevê a criação, nas áreas a norte do bairro na margem da estrada Provinciale n.15 "Via del Mare", de um vasto centro de atividades desportivas ou de tempo livre para recolocar algumas funções atualmente localizadas junto ao nó monumental de Santa Maria em Aula Regia. O presente projeto incluiu a transferência desta área para a cidade desportiva para se integrar com outras instalações, como por exemplo uma piscina municipal que atualmente não existe em Comacchio. A administração municipal está também envolvida no projeto. Esta solução é também uma hipótese para uma integração num centro multiusos do estádio da cidade, que hoje está afastado do centro urbano. Na presente proposta, esta cidade desportiva será também uma zona de segurança, situada entre o bairro e o eixo da estrada Provinciale, também graças à criação de um arvoredo na margem da artéria.

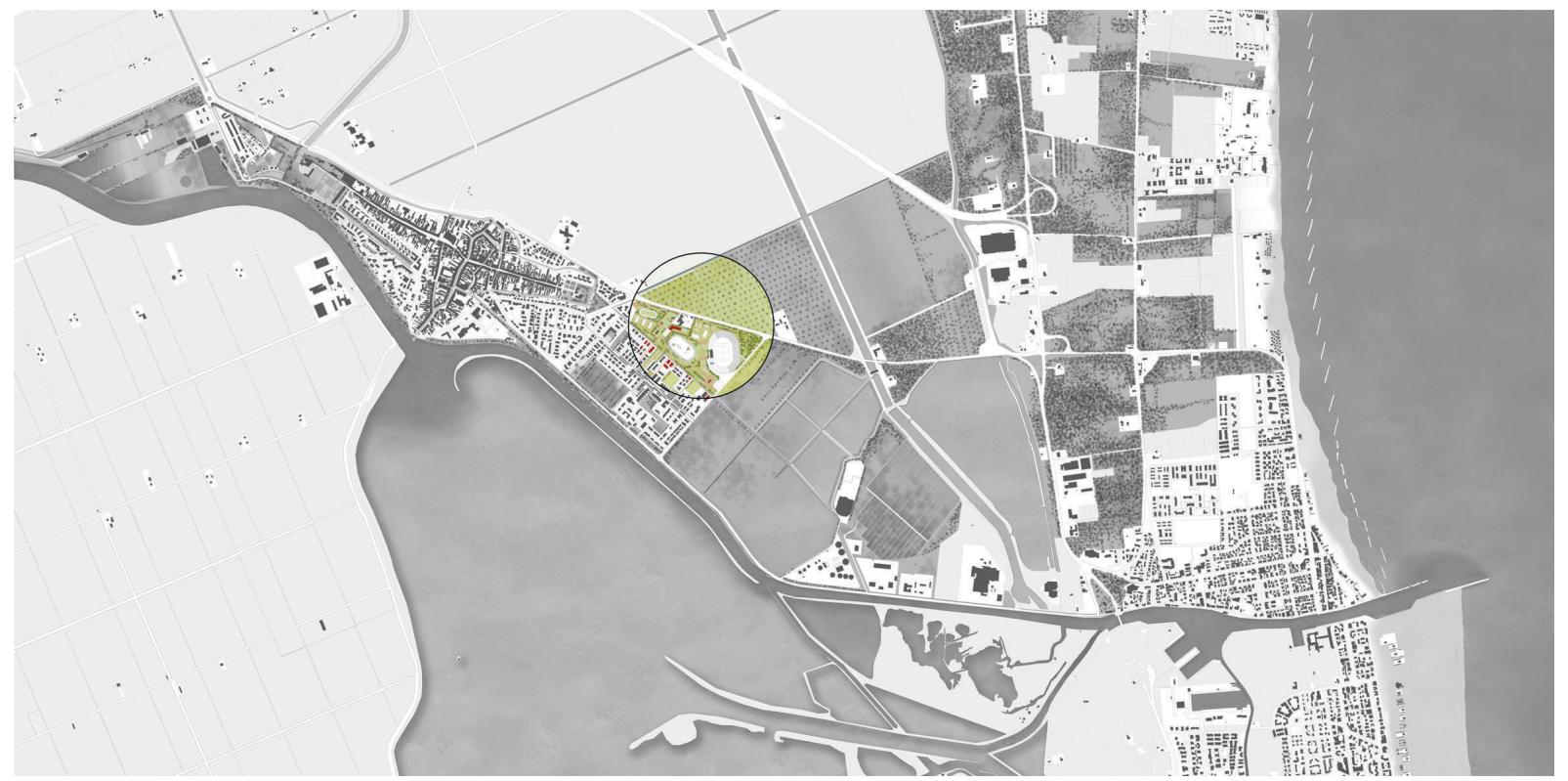

\section{Parque urbano}

Dentro deste vasto âmbito periurbano, atualmente subutilizado em termos agrícolas devido ao pouco rendimento dos terrenos, o projeto propõe a criação de um "parque periurbano" com arvoredo, percursos e equipamentos para o tempo livre, espaços verdes perto do edifício construído e zonas alagáveis para os períodos de maior seca da rede hidrográfica. Confirmam-se as previsões de aumento da área cemiterial, para a qual se propõe uma mitigação com a criação de um arvoredo. Prevê-se também a criação de uma série de reservatórios para fitodepuração, em ligação com o depurador comunal, atualmente objeto de um projeto para a sua atualização técnica. 

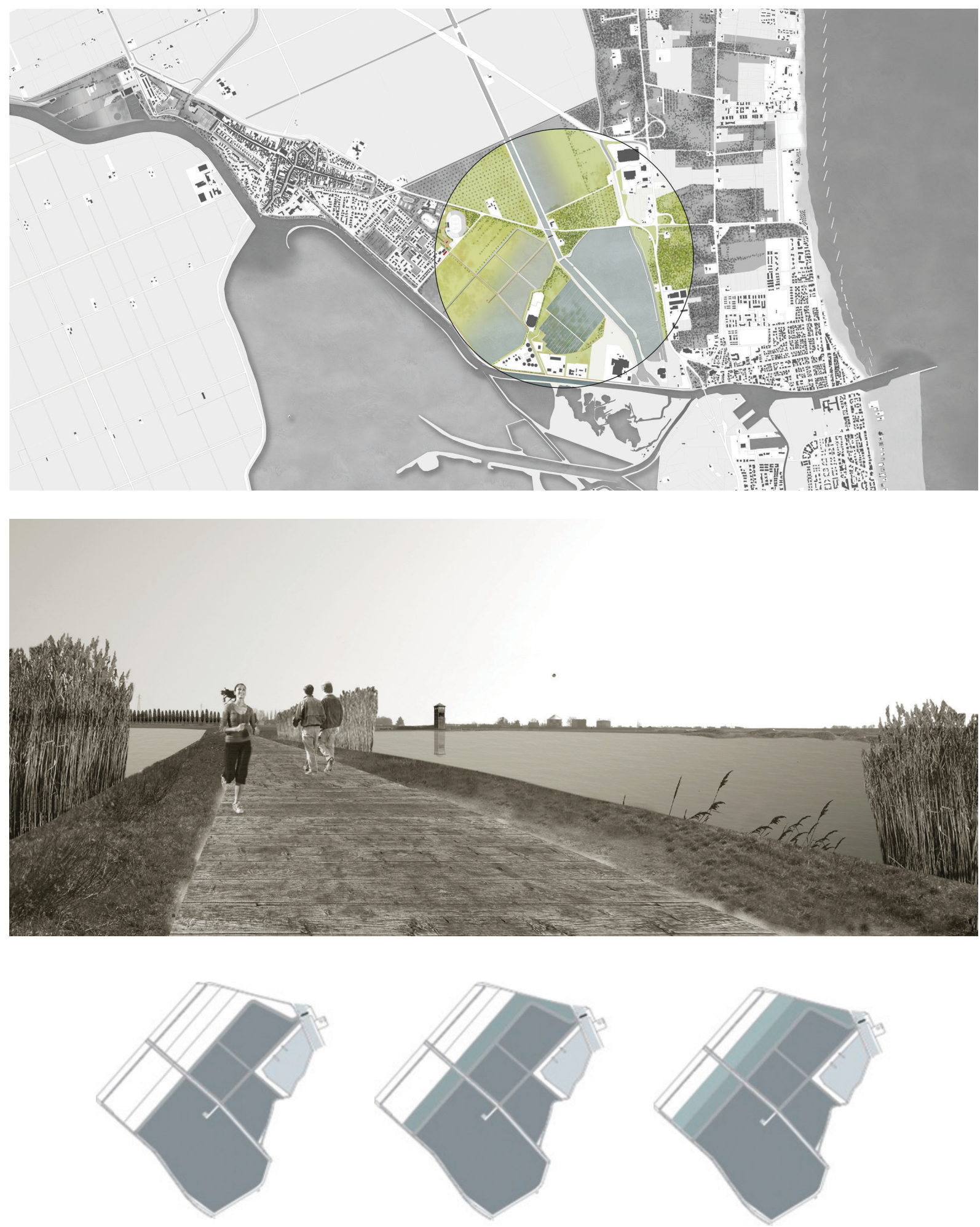

Alagamento progressivo e controlado 


\section{A DIMENSÃO CULTURALDA AGUA}

\section{$\cos 8$}

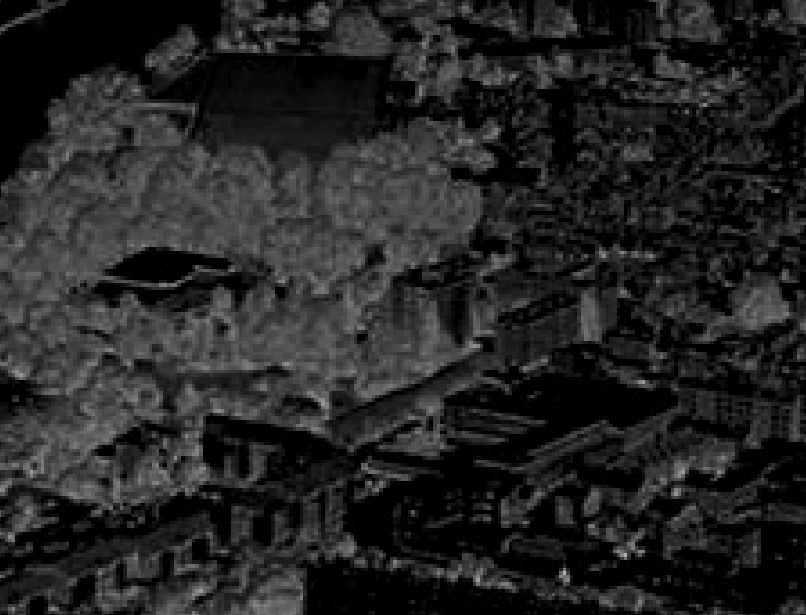

\author{
$\min 2$ \\ a.s.
}

RICHARD LEMEITER (Coordenador)
TULIEN PINON

artigy-

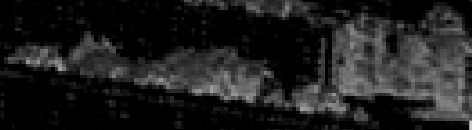

Definições em que ños apoiamos neste programa: ys

Água $=\mathrm{a}$ água sob todas as suas formas, todas as águas (subPatrimónio = bem herança comum de uma coletividade de um

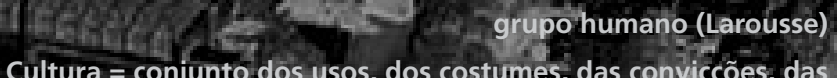
Cultura $=$ conjunto dos usos, dos costumes, das conviçções, das manifestaçôes art ísticas, religiosas, intelectuais que definem $\mathrm{e}$ distinguem um grupo, uma sociedade (Larousse)

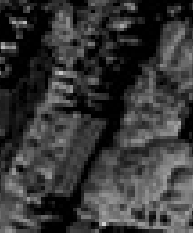

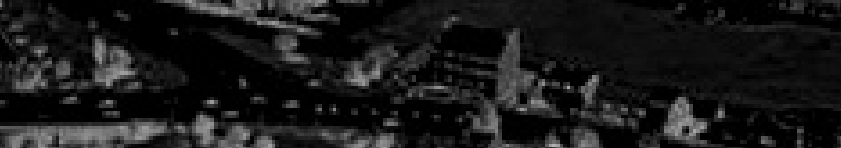

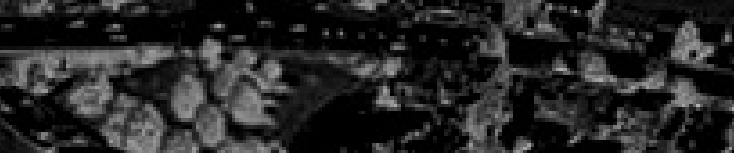

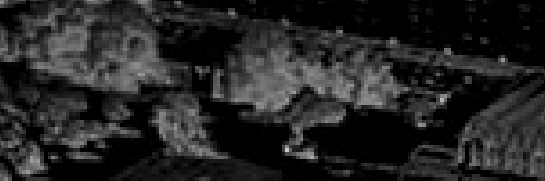

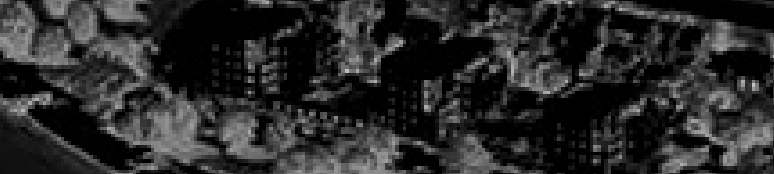
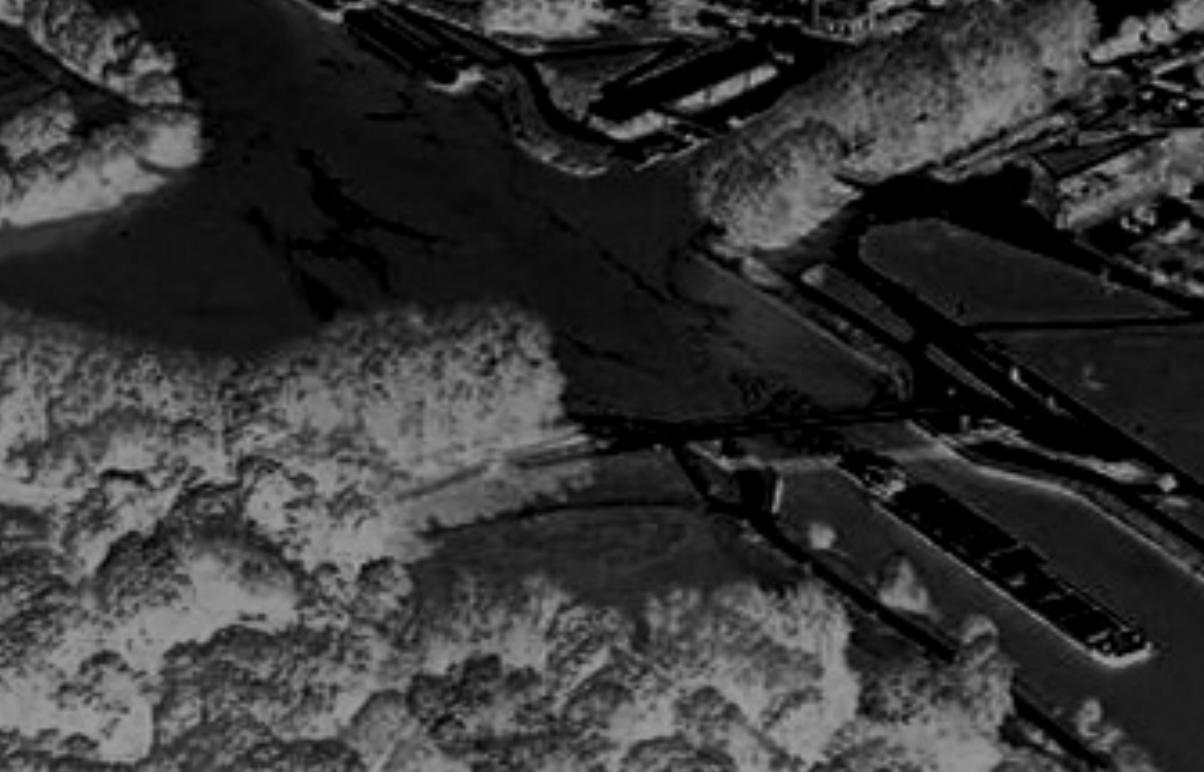


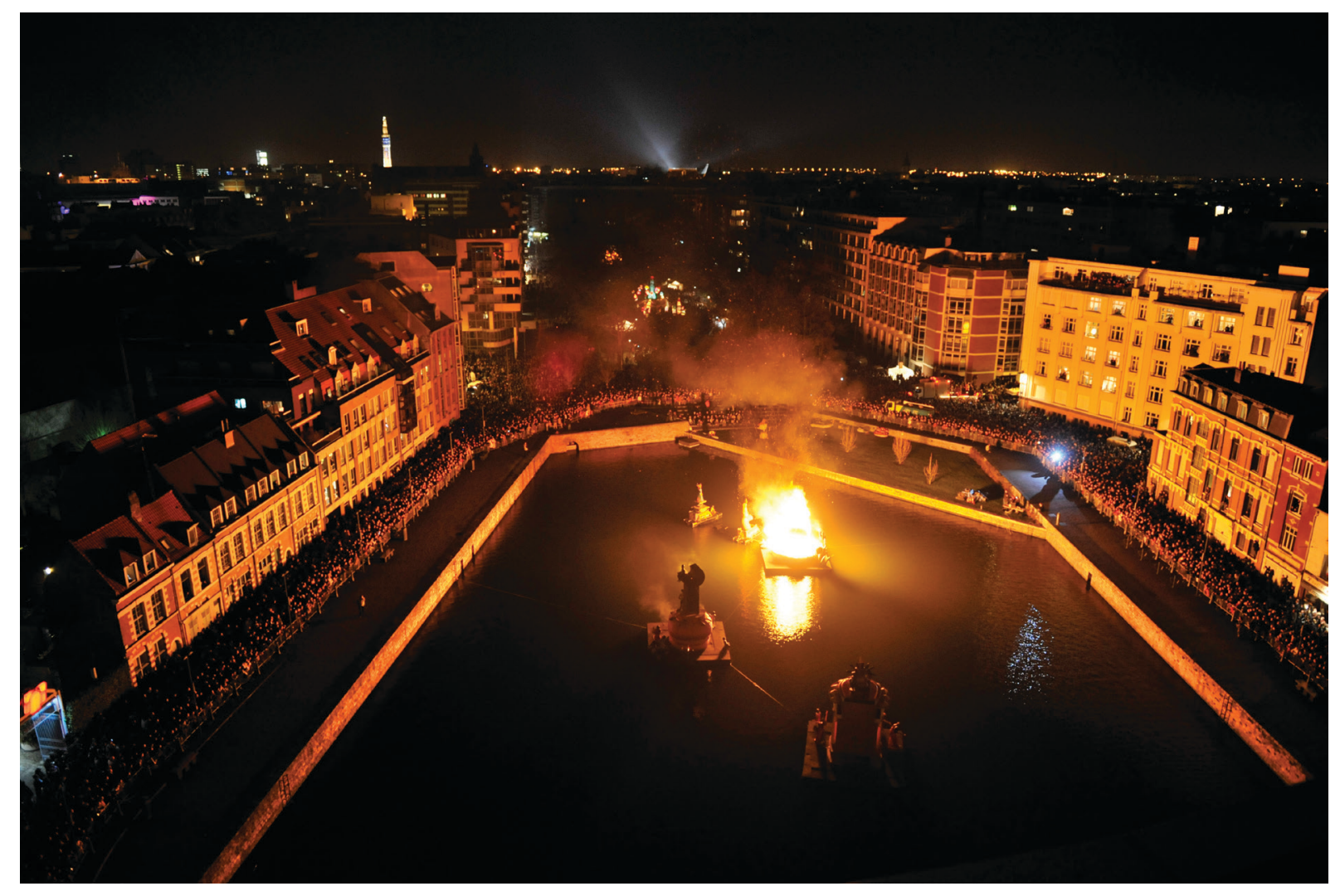

O Cais do Wault em 2004 - Cerimónias das Fallas 


\section{A PROBLEMÁTICA DA CIDADE DE LILLE}

Como estabelecer a dimensão cultural do rio Deûle para fazer dele um espaço mais utilizado, mais vivo?

A água pode ser abordada sob diferentes ângulos (estético, lúdico, patrimonial, cultural, ecológico, etc.), é um instrumento potencial de desenvolvimento.

Numerosas coletividades francesas e europeias comprometem-se atualmente com projetos de reconquista dos seus cursos de água e canais e isto, a escalas variáveis, que vão do simples cais de uma aldeia, ao projeto intermunicipal (Plano Azul Metropolitano da Metrópole de Lille), distrital, regional (île de France - Canal de l'Ourcq) ou mesmo transnacional (Estrasburgo).

Esta reconquista das margens passa, com frequência, pela encenação da água e a criação de espaços públicos que acolhem manifestações populares, culturais, dinamizações (margens do Sena transformadas em zonas pedonais, em Paris). Estas duas ações constituem frequentemente as próprias bases das políticas de retorno à água empreendidas em muitas cidades.

Assim se justapõem diferentes maneiras de animar os cursos de água urbanos. Às festividades ligadas a heranças do passado, vêm juntar-se acontecimentos de dinamização cultural, espetáculos que têm uma dimensão estética (encenação: iluminação, nascentes) ou uma dimensão mais prática e usual (lazeres, descanso, jogos de água).

Esta patrimonialização dos recursos ligados à água não tem uma dimensão museológica e ajuda a pensar a água como suporte vital, um lugar do qual depende um certo número de ecossistemas, mas também a fonte de uma dimensão cultural para fazer desse lugar um espaço mais utilizado, mais vivo.

No momento em que, em Lille, emerge o desejo de reencontrar as suas raízes aquáticas, o compromisso da cidade com um projeto europeu sobre a temática da água como suporte de acontecimentos culturais, abre pois uma via para a emergência de uma estratégia cultural de apropriação da água.

\section{O procedimento}

Este projeto europeu fez evoluir a nossa visão. Tomámos consciência da importância do Humano, do papel e do lugar dos habitantes num projeto urbano, para que o enxerto pegue e o projeto possa funcionar.

Até maio de 2012, o procedimento de Lille neste projeto europeu estava centrado na dimensão cultural (o património, os acontecimentos, a arquitetura) e num único lugar: a estação de água.

Desde junho de 2012, no final do workshop, a dinâmica elegeu o Humano como eixo ao longo de toda a linha do rio: a fita azul.

\section{O lugar do Humano, dos habitantes no projeto urbano}

Parece necessário voltar a colocar o Humano, os habitantes e os usos no centro da noção de património. Um projeto urbano deve ser concebido para os habitantes da cidade. 
Aquando da criação de um projeto de ordenamento, constata-se, com frequência, uma grande contestação por parte dos habitantes. É, frequentemente, devido ao facto de os habitantes não conhecerem o projeto e de imaginarem coisas erradas, levando-os a medos infundados.

Para evitar que isso aconteça, convém levar a cabo as seguintes ações:

- Informar, explicar as intenções do projeto;

- Concertar, pedir a opinião dos habitantes;

- Fazer visitar o lugar, pôr em situação física ou virtual (ateliers, imaginação, role plays);

- Ter em conta a memória e o sentimento dos habitantes relativamente ao projeto;

Um ordenamento deve constituir-se como um meio e não um fim em si mesmo.

Estes procedimentos vão ajudar os habitantes a compreender os desafios e os objetivos do projeto e, consequentemente, permitir-Ihes formar uma opinião com conhecimento de causa.

Convém lembrar que a vertente sociológica do SDEL revelou uma forte sensibilidade dos habitantes relativamente à temática da água e a grande maturidade da sua reflexão sobre o tema. Existe uma procura real de informação no que diz respeito à água e aos projetos do município de Lille ligados ao rio Deûle. Antes da realização dos projetos, parece pois fundamental comunicar amplamente os conteúdos do quadro aqui estabelecido no âmbito destes projetos, para que a sua finalidade e a sua justificação económica sejam bem compreendidas.

\section{A aplicação da problemática}

O rio Deûle e os seus antigos canais marcaram profundamente a história e influenciaram o desenho da cidade de Lille. Desse ponto de vista, constituem um património, um bem transmitido e a transmitir, cuja reabilitação e conquista estão doravante em causa. Convém assim valorizar o património de ontem e criar o património de amanhã. As potencialidades económicas, sociais e ambientais do Deûle estão ainda insuficientemente exploradas na globalidade do seu percurso, em contracorrente com a crescente procura dos cidadãos relativamente à natureza.

Atendendo à estreita relação entre o curso do rio e o curso da cidade, a possibilidade de utilizar o seu potencial identitário e jogar com o imaginário dos lugares é uma oportunidade para fazer nascer um novo laço afetivo entre a cidade e o seu rio bem como para melhorar o quadro de vida e a imagem da cidade. Constituindo uma estrutura em rede, as vias de água oferecem igualmente a oportunidade de Lille e a sua região apreenderem um território mais vasto e iniciar uma reflexão à escala da bacia hidrográfica.

Um projeto de ordenamento da via de água ligando cultura e urbanismo é para Lille a oportunidade de valorizar a sua imagem, ao mesmo tempo que procura colocar-se ao nível dos patamares europeus em termos de valorização da água como acontece em Amsterdão, Londres, Leipzig, nas cidades do vale do Ruhr, em Oslo, Copenhaga...

A reflexão sobre as potencialidades de dinamização do curso do rio Deûle deve ir de par com a condução dos projetos urbanos. A festa é aliás um bom revelador do "bom viver em conjunto". A "festivalização do ordenamento" é um tema particularmente interessante que deve ligar-se ao conceito de cidade intensa. 


\section{O trabalho dos estudantes}

Um atelier de urbanismo ou workshop foi levado a cabo em Lille durante uma semana no mês de maio de 2012. Quatro equipas internacionais de 6 a 7 estudantes - supervisionados por um professor de um dos quatro países - fizeram propostas de ordenamento de um local de cada país do programa europeu. Tratava-se das seguintes cidades: Braila na Roménia (Danúbio), Coimbra em Portugal (Mondego), Comacchio na Itália (no delta do rio Pó) e por fim Lille (Deûle). O local selecionado para Lille era a da estação de água, situado a cavalo entre as municipalidades de Lille e de Lomme.

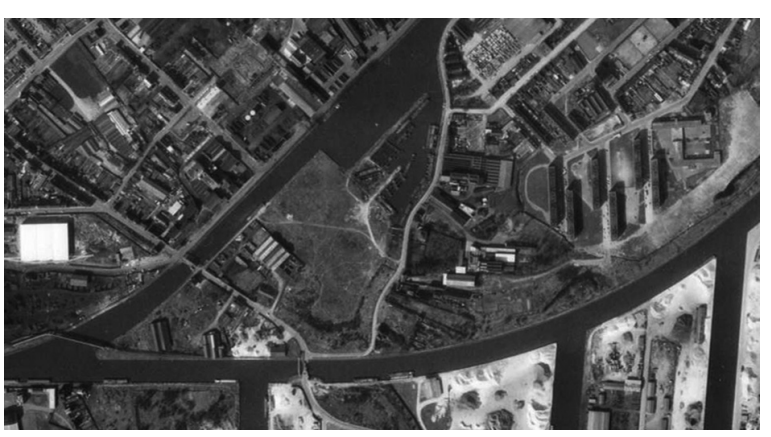

1969

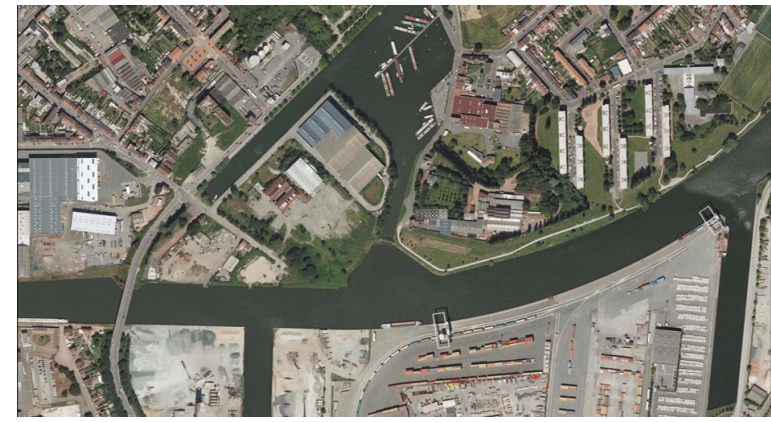

2012

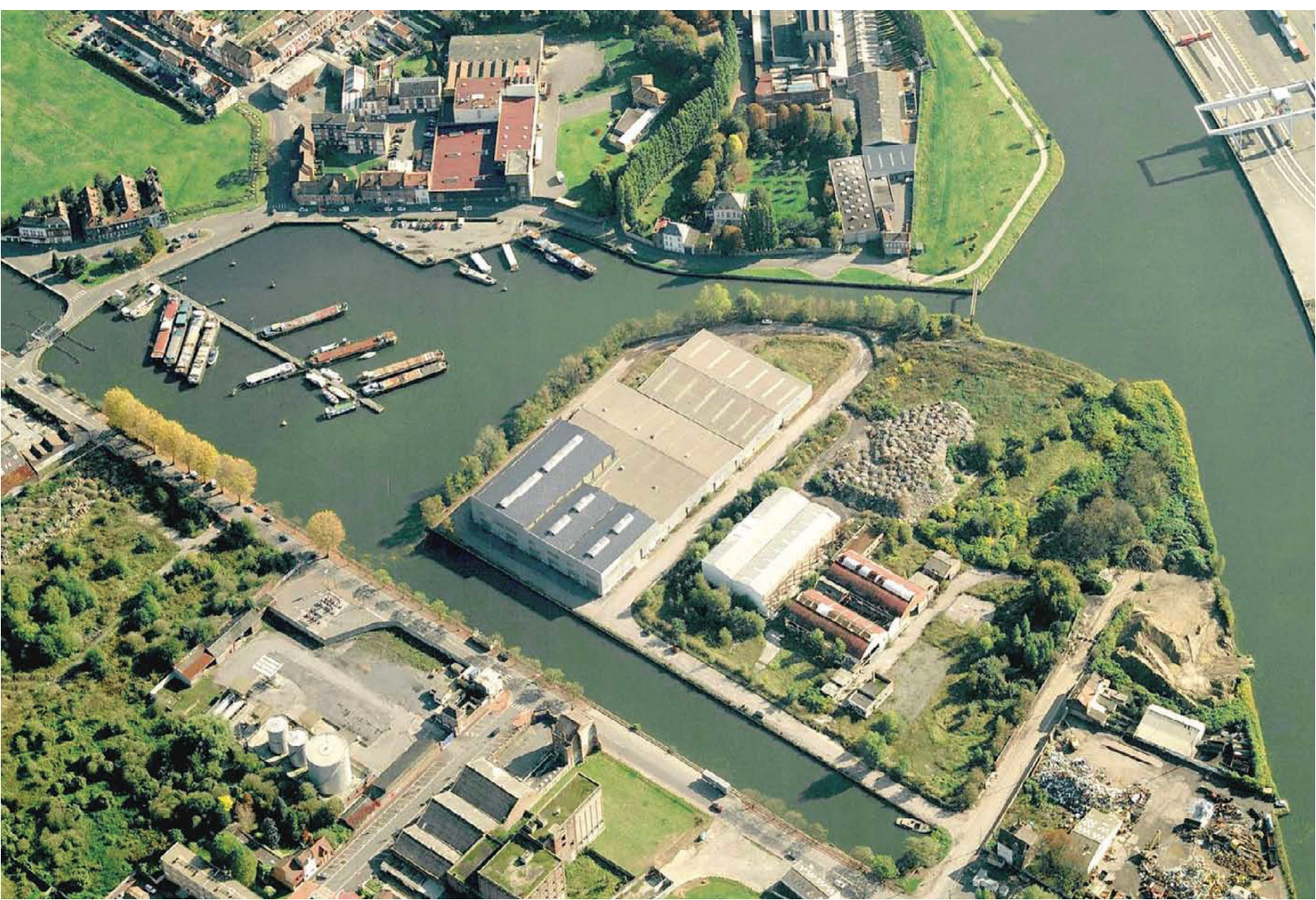

Estação de água e quase ilha Boschetti - 2012 
$3=2 x=3 x$

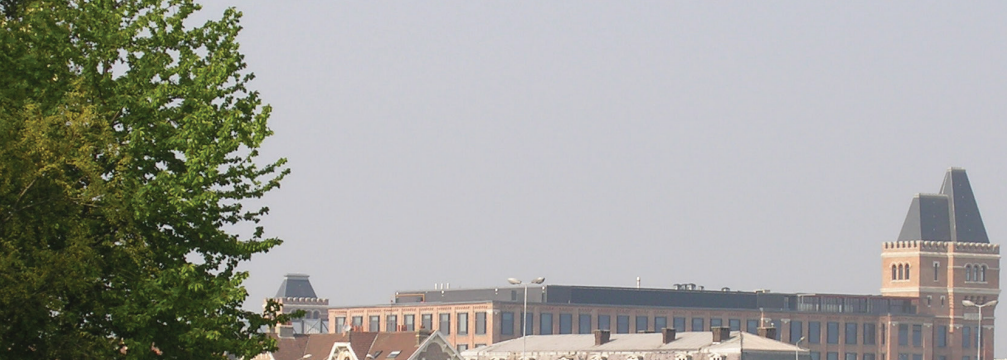

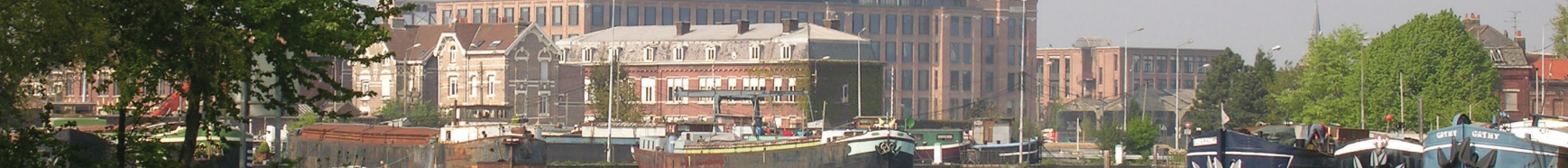

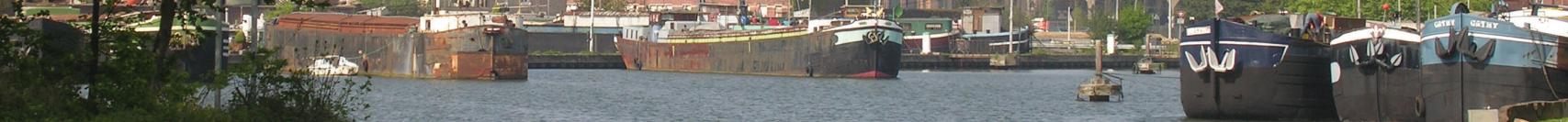

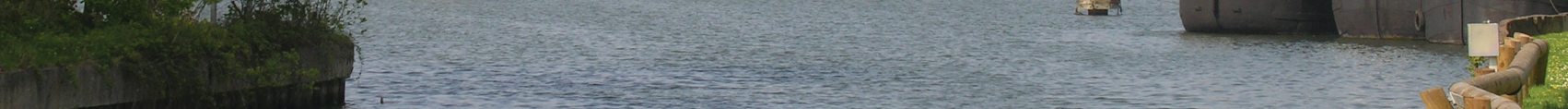
20.

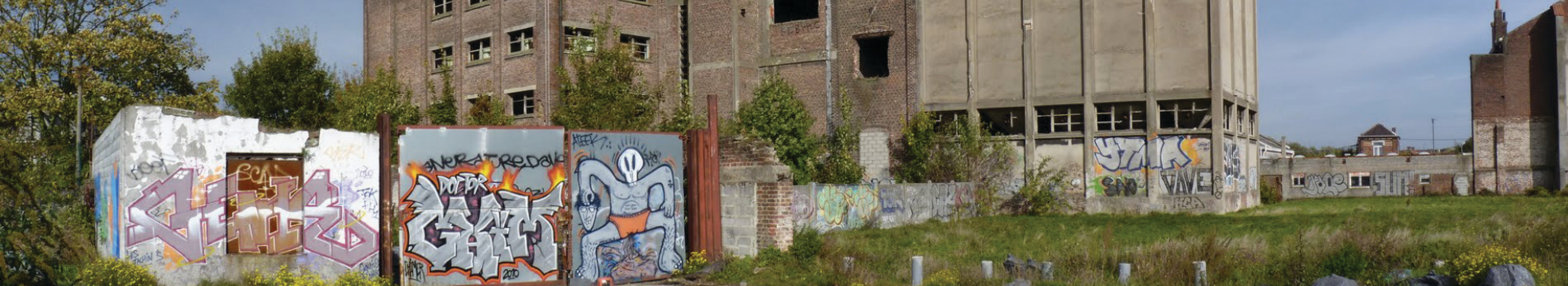
4

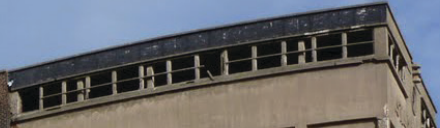

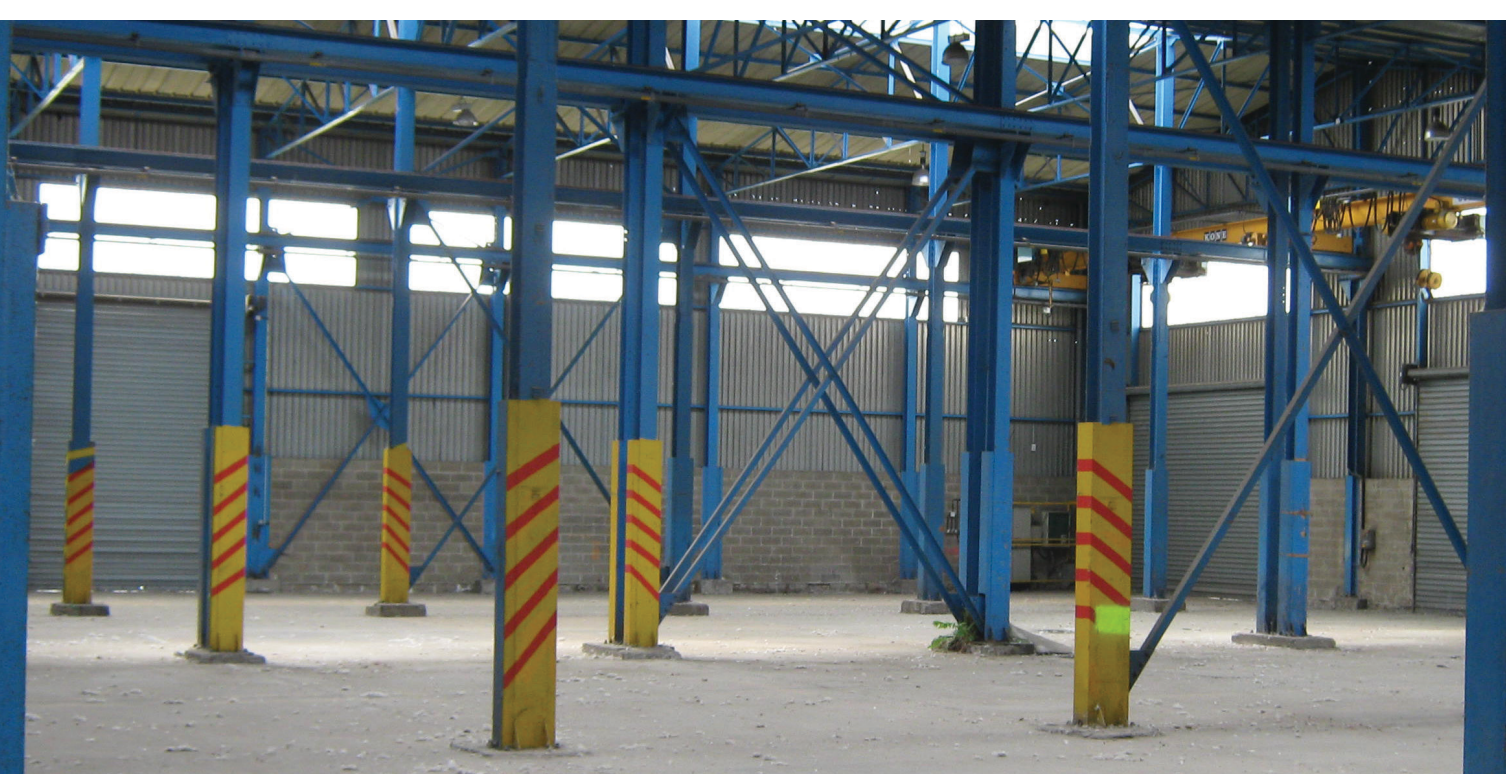

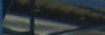

$>$

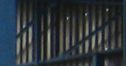

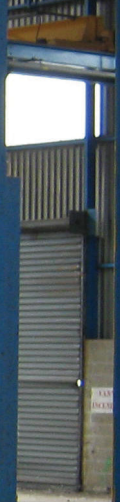




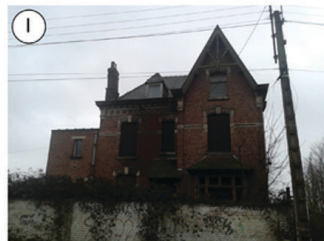

(2)
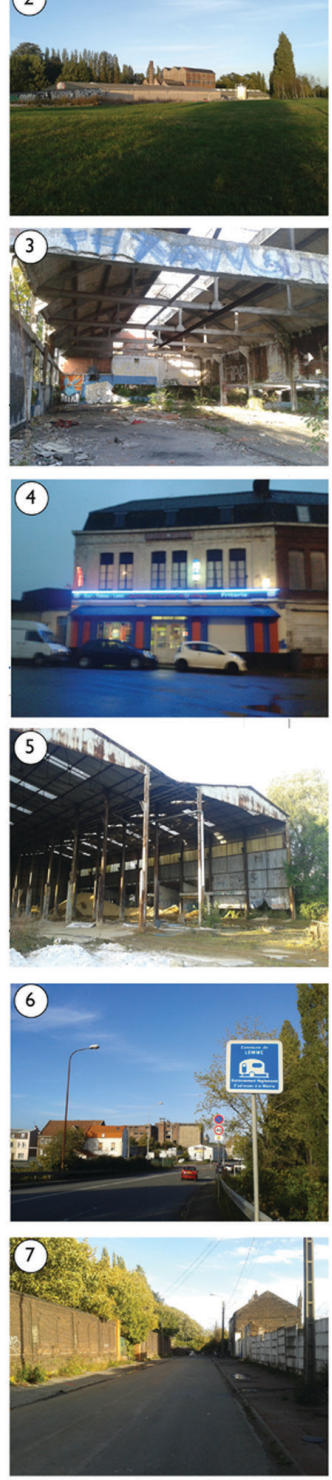

(8)

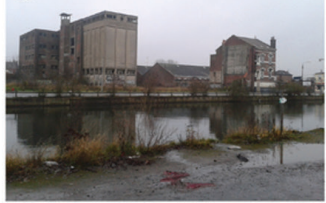

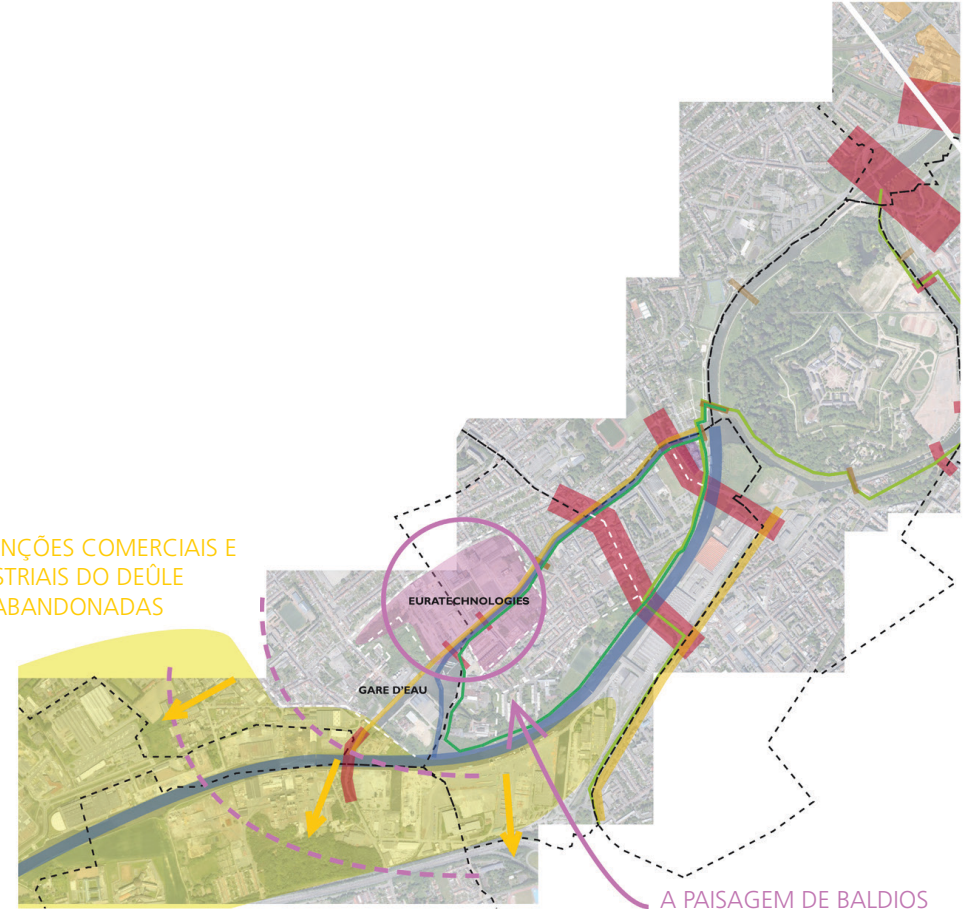

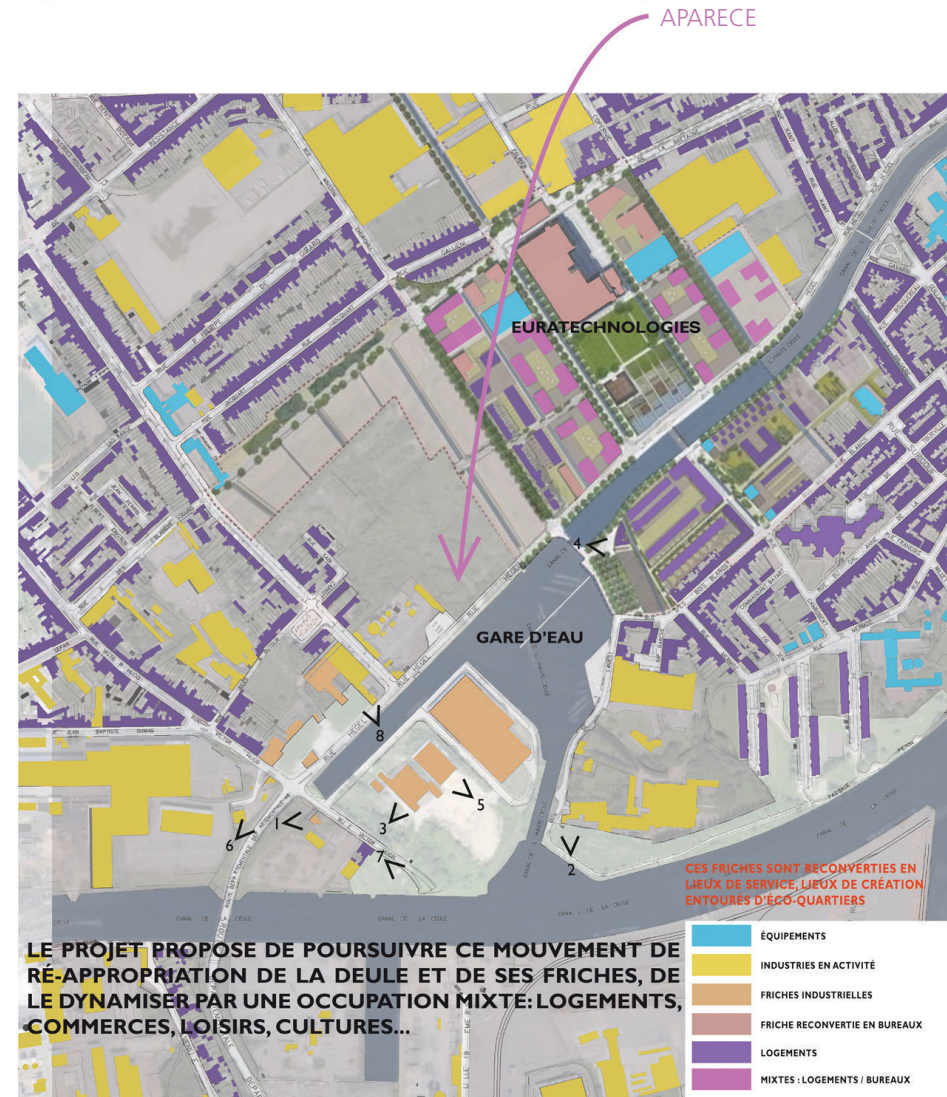

O PROJETO PROPÕE CONTINUAR O MOVIMENTO DE

REAPROPRIAÇÃO DO DEÛLE E DOS SEUS BALDIOS, DINAMIZÁ-LO PARA UMA OCUPAC ÃO MISTA DE ALOJAMENTOS, COMÉRCIOS, LAZERES, CULTURA... 


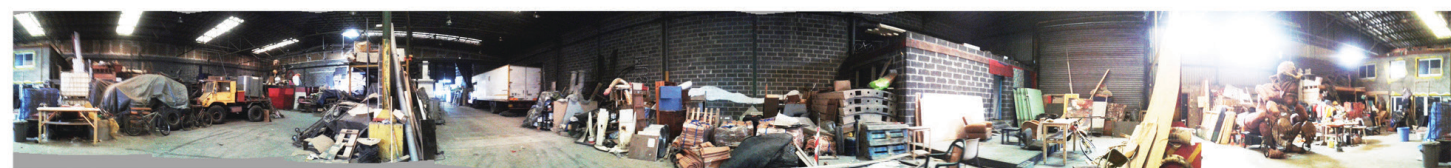

\section{CENÁRIO I - PROJETO}

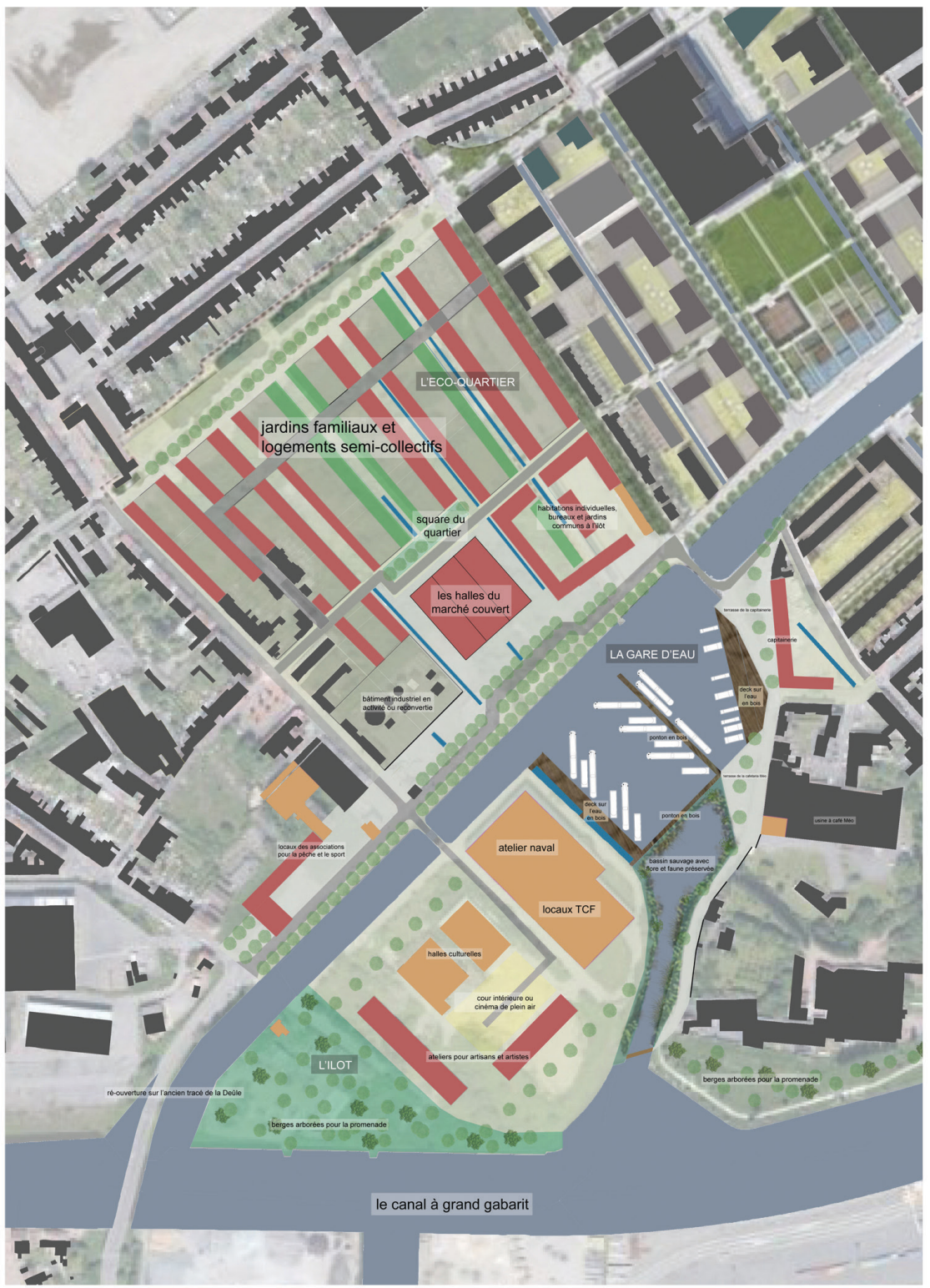

\section{IMAGESDERÉFÉRENCES}
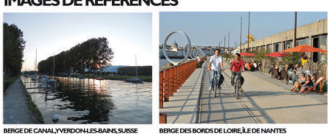

\section{SCHEMADIRECTEUR INITIAL}

GERME\&JAM-200I

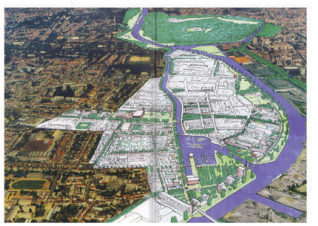

UMA MISTURA DE OCUPAÇÃO

DE USOS

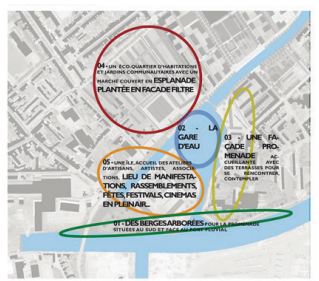

CRIAÇÃO DE 3 FACHADAS ANIMADAS PARA DELIMITAR A ESTAÇÃ̃ DE ÁGUA

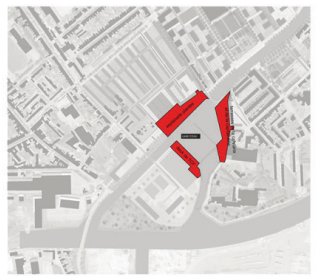

TIPOLOGIAS DAS DIFERENTES PEÇAS DE ÁGUA E DAS SUAS MARGENS

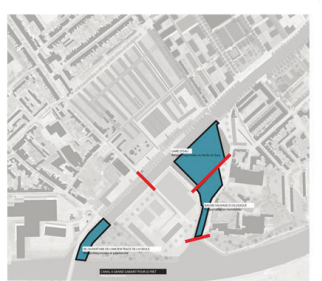



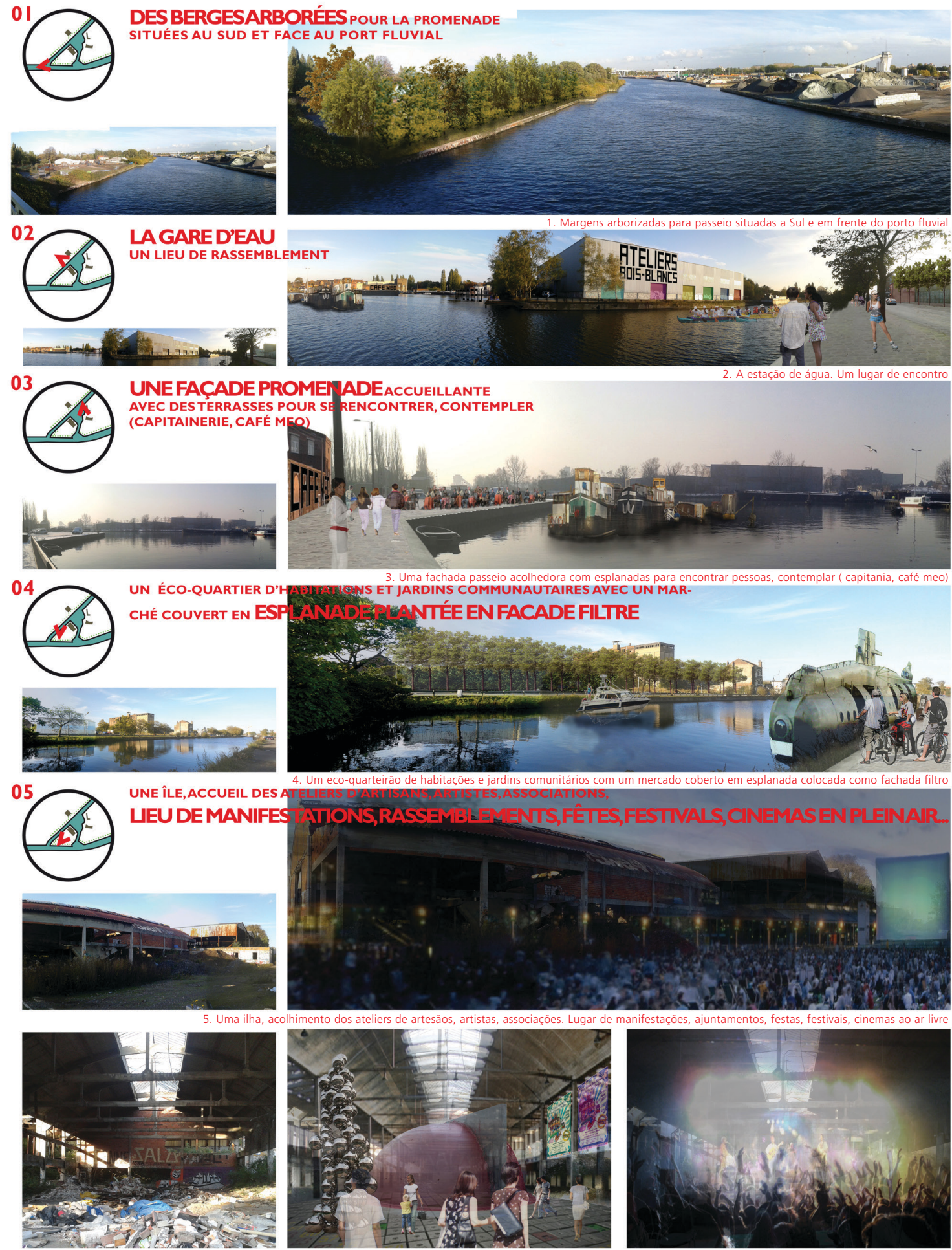


\section{Na sequência do workshop de maio 2012 em Lille}

Um estudo urbano foi lançado por Lille Metrópole e pela cidade de Lille. Uma equipa pluridisciplinar foi assim encarregue de realizar um diagnóstico e propostas de ordenamento para este sítio.

Paralelamente, os estudantes da Escola Nacional Superior de Arquitetura e Paisagens de Lille prolongaram o trabalho levado anteriormente a cabo pelos estudantes do Instituto de Ordenamento e Urbanismo de Lille, alargando o perímetro de reflexão ao conjunto da Metrópole de Lille.

\section{Vale do Marque}
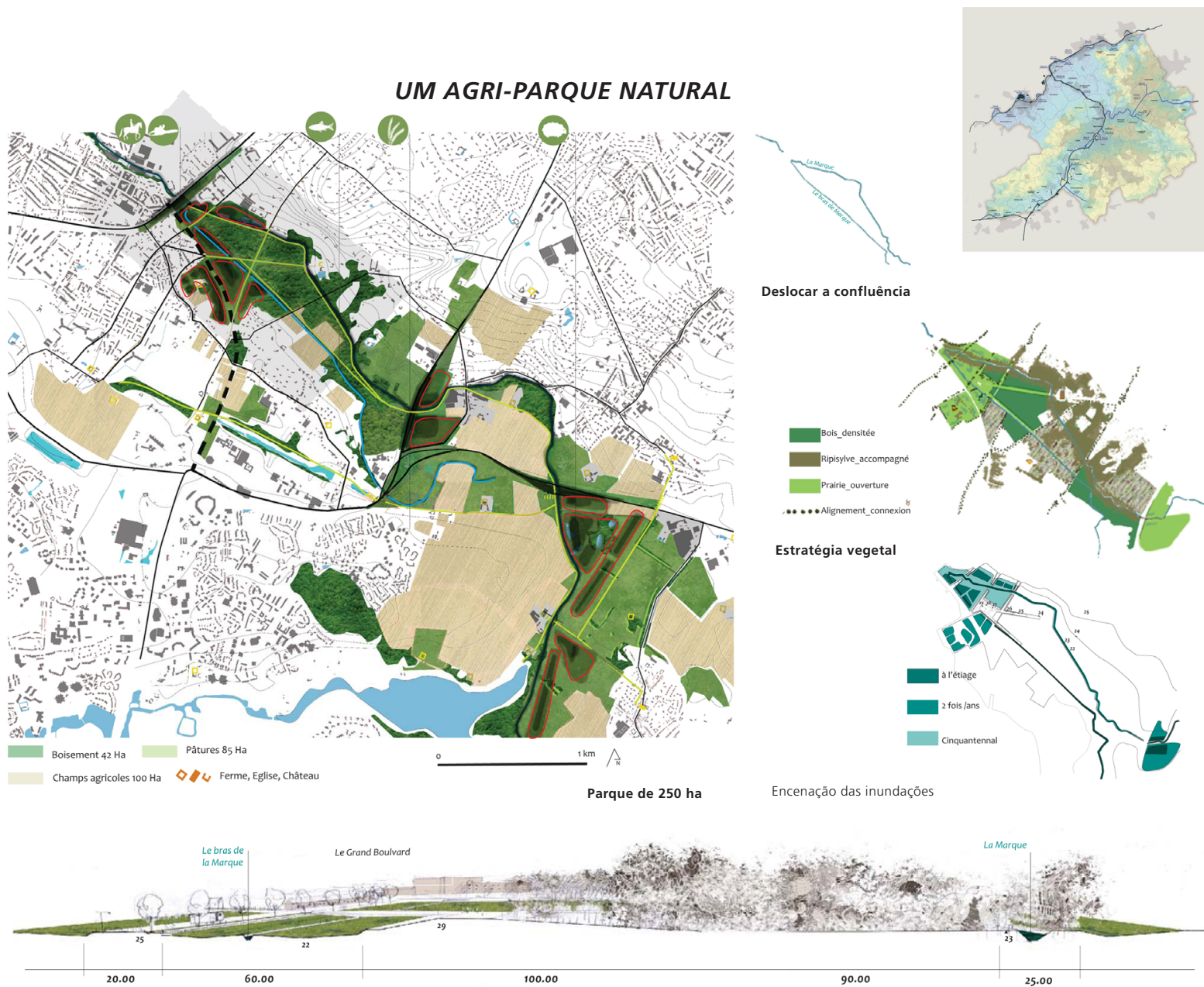

O equilíbrio aterro / terraplanagem dá forma ao parque 


\section{Canal de Seclin}

TURISMO RURAL - AgROTURISMO

O turismo rural é uma forma alternativa de turismo em meio rural, designadamente junto dos agricultores (agriturismo ou agroturismo) ou dos viticultores

(enoturismo) mas também entre as pessoas que habitam no campo ainda que năo vivam da terra.

\section{$1+\frac{1}{3}$}

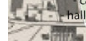

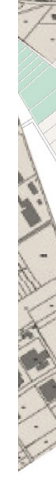

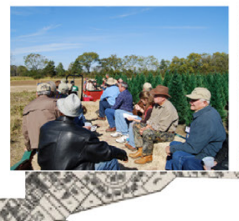
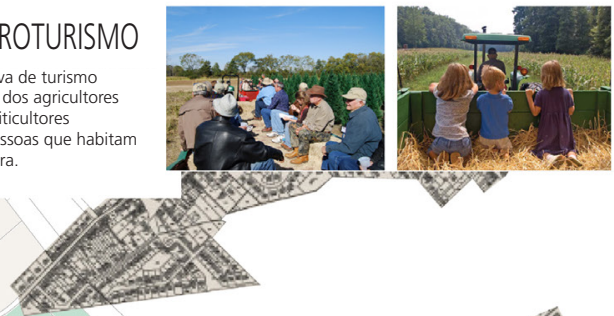

3. $\rightarrow$

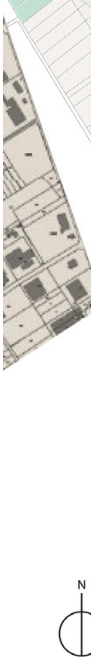

N
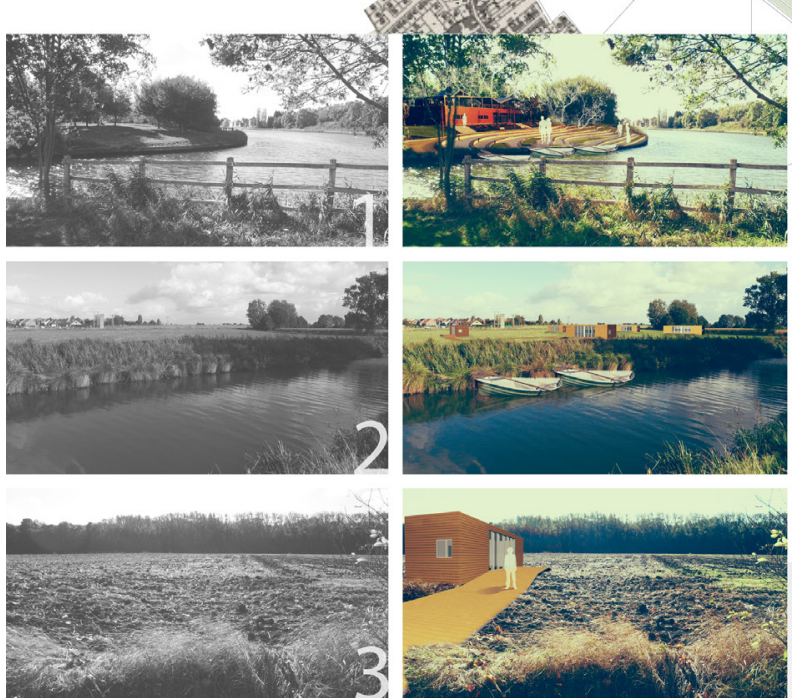
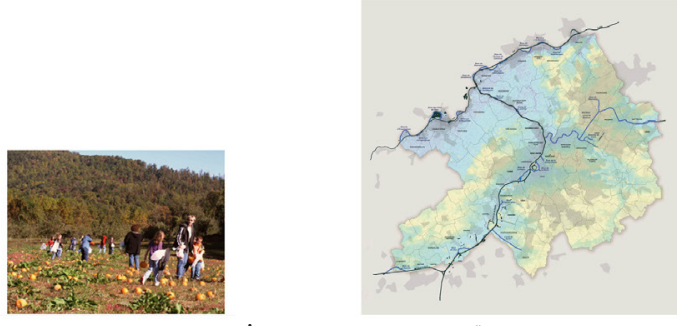

AS FORÇAS DE ORGANIZAÇĀO

beneficiando da presença da Casa Pouillerie, aumentar a reder de agroturismo:

descobrir o território mergulhando nele;

alargar as dimensōes de tempo e de espaço;

ligar o território da agricultura com o lugar de Seclin utilizando as embarcações;

garantir a acessibilidade do pavilhão pelo canal;

desenvolver o território que perdeu a função industrial a partir de uma estratégia hibrida

abrir o território à cidade, mas com menos elementos mais instrumentos;

reforçar a permanência temporária nos pavilhões - cultivando o tereno e usando a água.
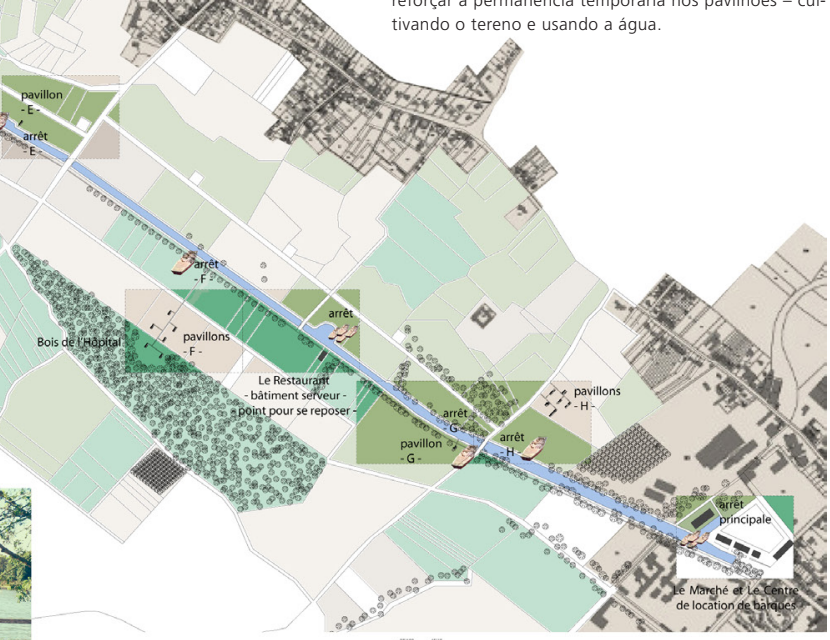

Pavillon - Module
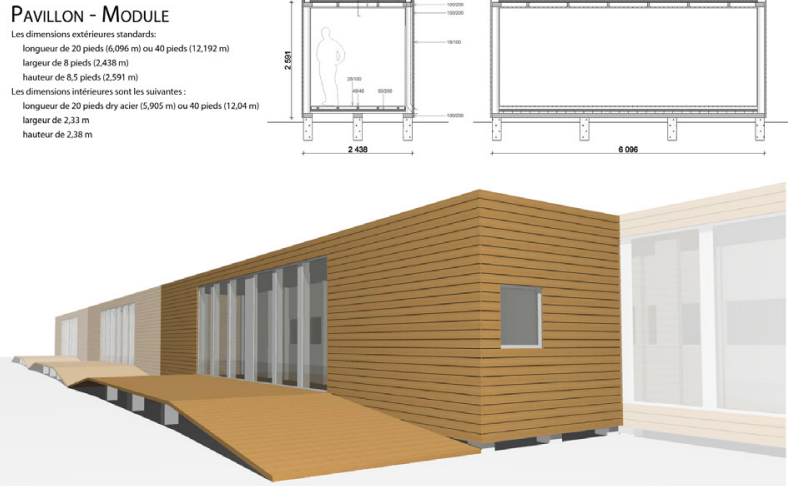


\section{Abrir, recuar no zoom}

Da complementaridade à transversalidade das abordagens nos projetos de reabilitação da água na cidade.

A fim de levar a cabo uma ação coerente, convém retroceder no zoom, ter uma reflexão à escala metropolitana. É preciso trabalhar em rede, com os outros municípios e instituições públicas. É igualmente interessante e útil apoiar-se nas associações. O trabalho levado a cabo ao longo deste projeto europeu reconfortou-nos na ideia de que não é possível funcionar sozinhos. É preciso pôr os lugares, os meios e os projetos em rede, em comum. Com efeito é interessante conduzir ações multi-lugares, no conjunto do rio.

É preciso refletir em termos de complementaridade e não de concorrência. Este trabalho em rede, o facto de trabalhar em cooperação com outras cidades deve fazer-se no próprio território mas também à escala internacional.

Convém aplicar o procedimento deste seminário a outros projetos, em outros domínios (o social, a investigação, a inovação, etc.). Paradoxalmente, falamos da água mas com um olhar de terrestres.

Não seria interessante modificar o nosso ponto de vista e olhar para o nosso património a partir da água?
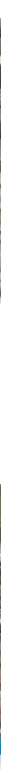

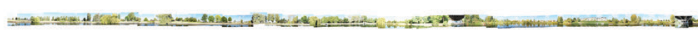

Bosque Branco
Lambersat
Baixo Deûle 


\section{Baixo Deûle}

Água lúdica e artes fluviais

Margens para prática desportiva e natureza na cidade

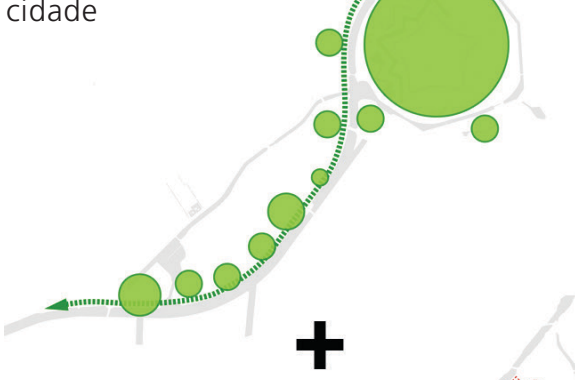

Bairro-Canal patrimonial, habitado e festivo

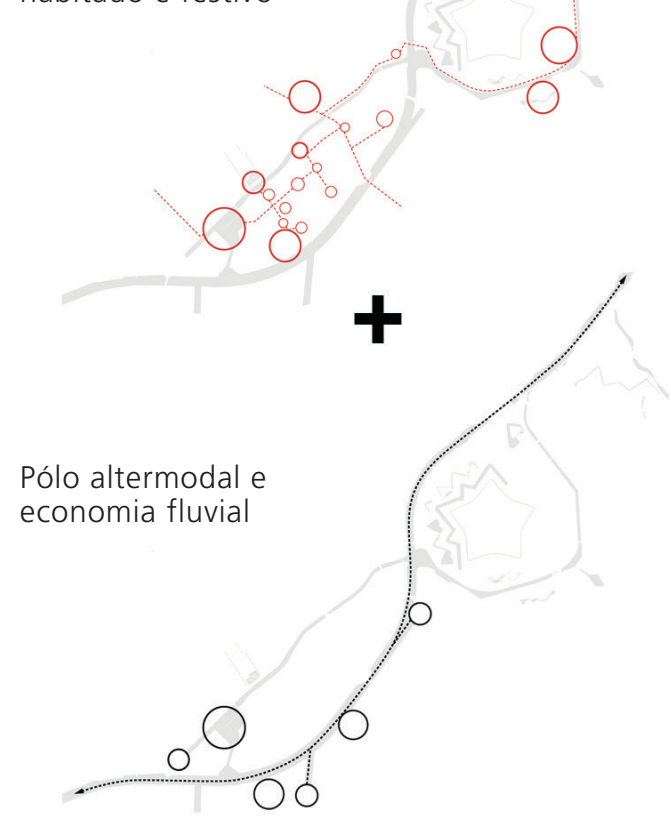

\section{Conclusão}

Alargamento da problemática passando:

- Do património à cultura;

- Do ordenamento ao Humano;

- De um lugar único ao conjunto do rio;

- Necessidade de trabalhar em rede;

- Tomada em consideração dos habitantes.

Este tipo de seminário europeu representa uma oportunidade para todos. Esta cooperação, o facto de não mais trabalhar sozinhos, permite abrir a reflexão e a ação.

Abertura geográfica:

A fim de realizar estes objetivos e estes projetos, torna-se necessário trabalhar com os municípios vizinhos tendo presente o que se faz noutros lugares em França e na Europa.

Abertura temática:

Aplicámos as problemáticas dos outros países (biodiversidade, património arquitetónico, desenvolvimento económico) ao nosso espaço e à nossa reflexão sobre o território de Lille.

Quatro problemáticas que convergem para a estação de água e determinam dois níveis de intervenção:

- Com pinceladas sucessivas ao longo do percurso;

- Com uma ação massiva focando a estação de água e a península de Bosquetti. 


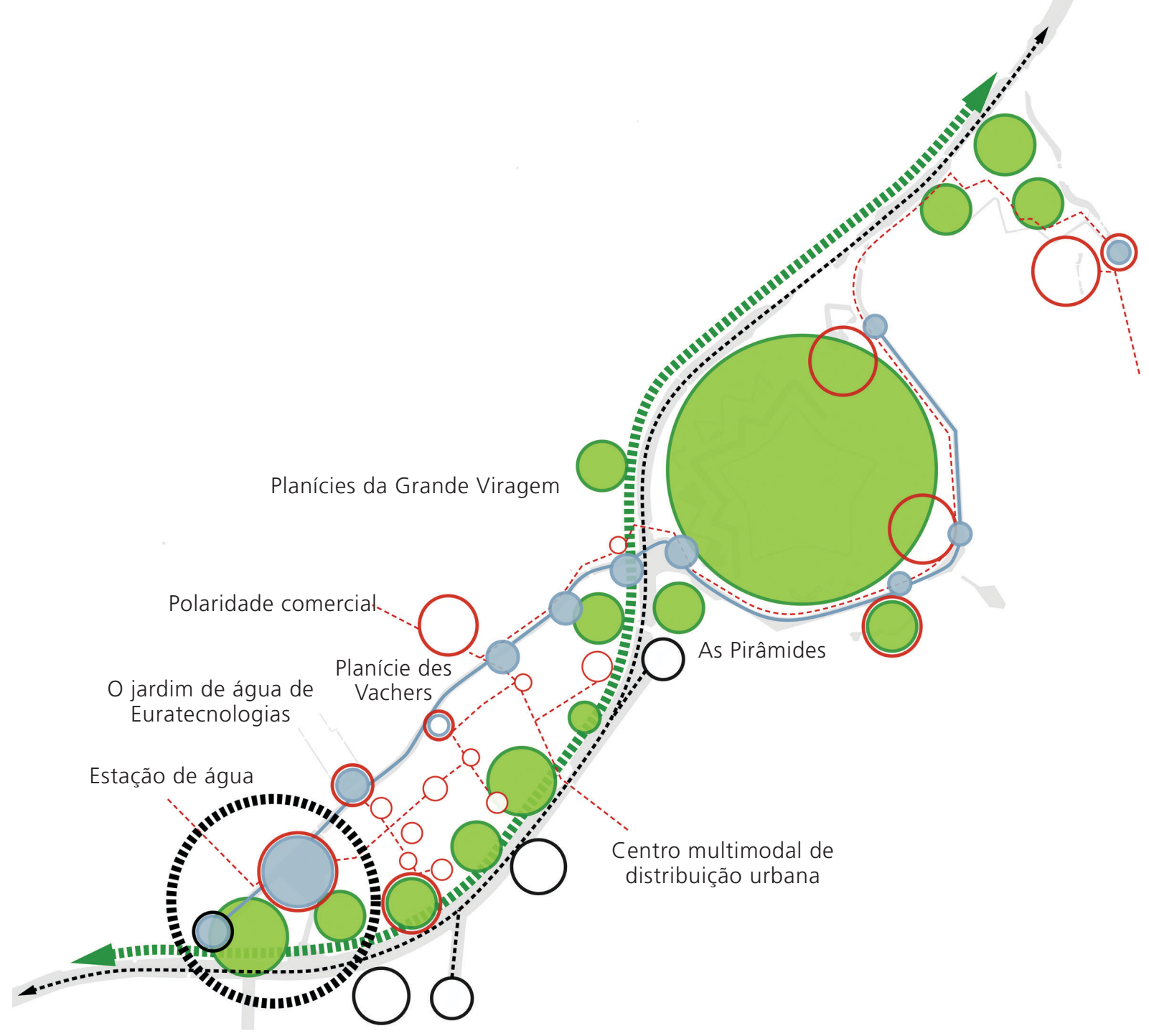




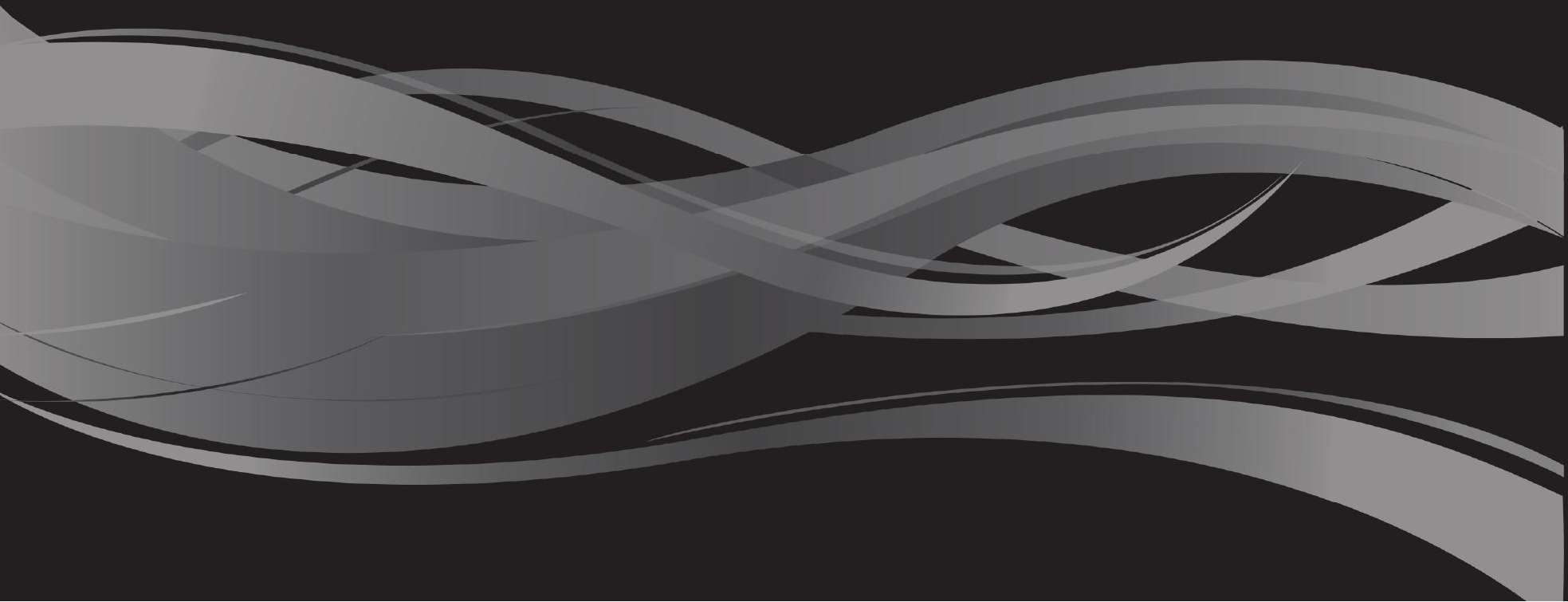


Considerações finais 


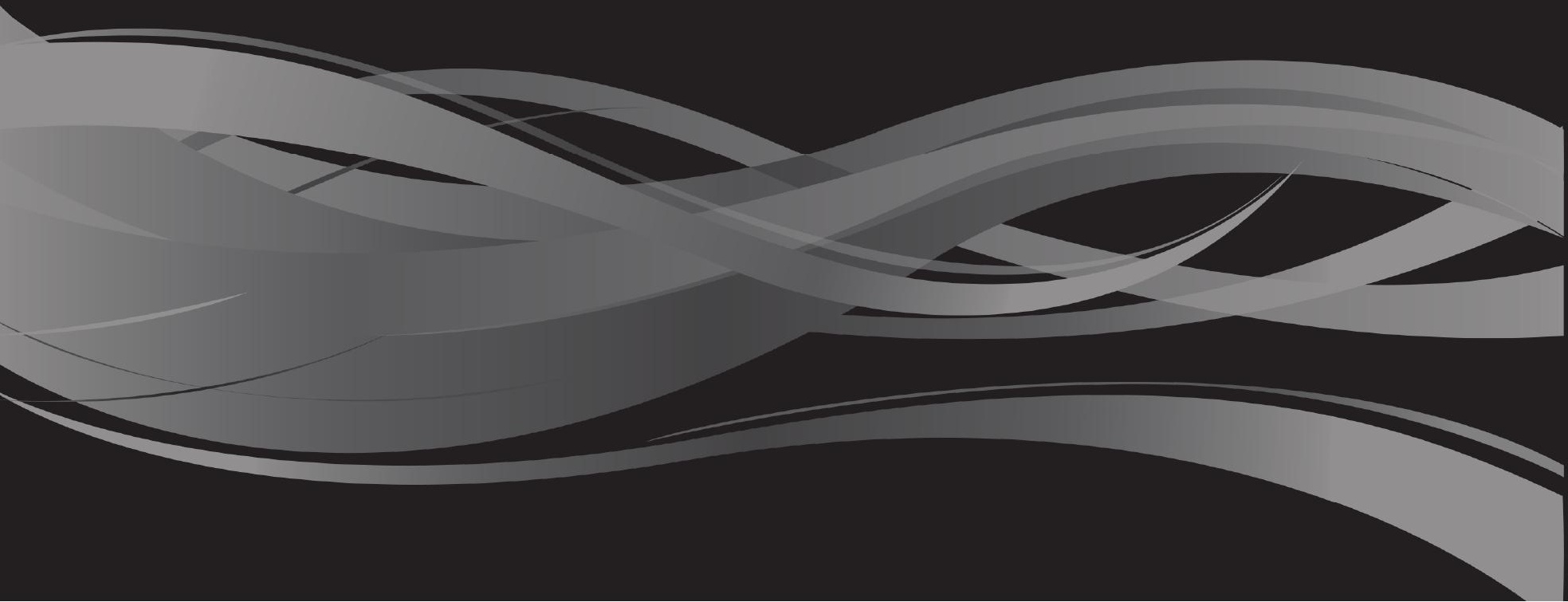


Esta obra resulta de um projeto internacional, desenvolvido em 4 países. Trata-se de uma versão em português, revista e abreviada, do livro "Acqua come patrimonio - Esperienze e savoir faire nella riqualificazione delle cita d'acqua e dei paesaggi fluviali" (organização de Romeo Farinella, editora Aracne, Roma). Está dividida em 3 partes. Numa primeira parte é enunciada a problemática. Na segunda parte, sob a forma de Atlas, é feito um diagnóstico dos 4 territórios. Por fim, na terceira parte, apresentam-se os 4 projetos de intervenção, consubstanciando ideias e propostas concretas para os territórios abrangidos pelo projeto.

Inseridos em contextos muito díspares, sob vários pontos de vista, e enquadrados em escalas, também elas, muito diferenciadas, os 4 territórios são estudados e problematizados a partir de uma perspetiva comum. A água, sob as diversas formas em que está presente em cada um dos territórios, é encarada como um instrumento de planeamento urbano, de modo a facilitar abordagens metodológicas e a comparação de experiências que fomentem oportunidades de requalificação territorial a partir de intervenções baseadas na presença da água.

A conceção e o desenvolvimento do projeto que sustenta esta obra empresta-lhe um caráter sui generis que consideramos enriquecedor. Porque envolveu um vasto número de pessoas, misturando o olhar académico, o olhar técnico, o olhar político e olhar cidadão. Porque privilegia uma leitura integrada dos territórios, evitando abordagens meramente estéticas, lúdicas ou exclusivamente centradas num determinado ponto de vista, permitindo, por essa via, problematizar a água como instrumento de planeamento regional e urbano. Ou porque, sem esgotar os argumentos, incrementou uma prática interdisciplinar, globalmente considerada pelos participantes como um eixo fértil de produção e de difusão de conhecimento.

Um dos maiores desafios, e poder-se-ia acrescentar dos maiores dramas, das civilizações urbanas em que vivemos é a relação individual e coletiva que mantemos com a água. Situação que é transversal e abrangente, envolvendo pessoas em condições sociais muito diferenciadas e países com níveis de desenvolvimento muito díspares. A água é o maior desafio civilizacional dos nossos dias. E se esse desafio não se faz mais presente é porque, paradoxalmente, a água é, para muita gente, um elemento visualmente omnipresente. Esse paradoxo pode ser ilustrado se retivermos o exemplo de uma metrópole como São Paulo, onde milhões de pessoas circulam e permanecem, presas no tráfego, quotidianamente, nas margens de um dos rios que atravessam a cidade. Para, à mínima anomalia pluviométrica, se darem conta das necessidades de racionamento e terem que enfrentar mudanças de comportamentos de usos para os quais não estão nem sensibilizadas, nem preparadas. Tanta água e sem água.

Diversos organismos internacionais introduziram há muito as questões da água nas suas agendas e nas suas prioridades. Desde que a ONU organizou, em 1977, a Conferência da Água, vários eventos se seguiram perseguindo objetivos semelhantes. A UE, como esta obra revela, nascendo o projeto que está por trás deste trabalho dessa orientação, tem ela própria vindo a consolidar uma política abrangente para a água. Aqui e ali, multiplicam-se os eventos que sensibilizam as pessoas para a importância civilizacional da água. Ainda que estes eventos não obedeçam a uma lógica meramente comemorativa ou simbólica, a questão essencial não é de sensibilização para a pluralidade de problemas ligados 
à água. A questão essencial passa por introduzir as questões da água no quotidiano das pessoas. Sobretudo daqueles que a usam como não deveriam usar. Por isso se torna tão importante converter a água num instrumento incontornável de planeamento urbano e regional.

A acesso a água potável - que é uma miragem para milhões de pessoas; viver quase exclusivamente para garantir quotidianamente a água indispensável à sobrevivência - como acontece com milhares de mulheres e crianças obrigadas a calcorrear diariamente muitos quilómetros; a morte dos rios - que se tornou um fenómeno global - devido à poluição, ao desenvolvimento ou ao crescimento urbano; as alterações climatéricas e os seus efeitos nos ciclos da água, na produção agrícola e nas reservas sólidas do Planeta - que estão em vias de agravar uma catástrofe que se anuncia; são, todas elas, questões mediáticas e prementes. Muitas vezes parecem ser apenas o problema de alguns. Tanto mais que nos países mais desenvolvidos a água entrou, nas últimas décadas, numa dimensão patrimonial e paisagística. Este estatuto, por um lado, renova e reinventa as funções sociais da água, mas, por outro lado, insere-a também numa dimensão de extraordinariadidade e de espetacularização que não é propícia a uma gestão integrada da água. Os eventos e os equipamentos que alimentam este novel estatuto da água, por regra, estão localmente enraizados e obedecem a uma lógica concorrencial que os afasta da função primordial que a água sempre teve como formatadora de territórios que partilham um destino comum. É esse o seu ethos patrimonial.

O projeto desenvolvido e os 4 casos estudados não têm a ambição de discutir todas estas questões. Na sua imensa diversidade, o que os 4 casos nos mostram é uma história comum de interesse recente pela água e pelas paisagens fluviais enquanto instrumento de planeamento, contrastando com um trajeto, mais ou menos longo, de profunda transformação, mas também de menosprezo, negligência e maus-tratos. Os 4 casos partilharam também, pela mobilização de agentes diversos, esse esforço de inscrição no quotidiano das pessoas dos desafios inerentes à água, da relação da água com a memória coletiva, da importância da água para o ethos local e o seu papel no domínio da requalificação e da regeneração urbana. Porque a água será, pelo menos tanto quanto foi no passado, um elemento estruturante das nossas vidas, este livro procura lançar algumas pontes para o futuro, ambicionando que as problemáticas levantadas e as sugestões deixadas possam ter relevância local, sendo ao mesmo tempo inspiradoras para pensar outras realidades. 
(Página deixada propositadamente em branco) 


\section{T \\ U}

IMPRENSA DA LNIVRSIDADE DE COIMBR
COIUBRA LNIVERSITY PR

f.

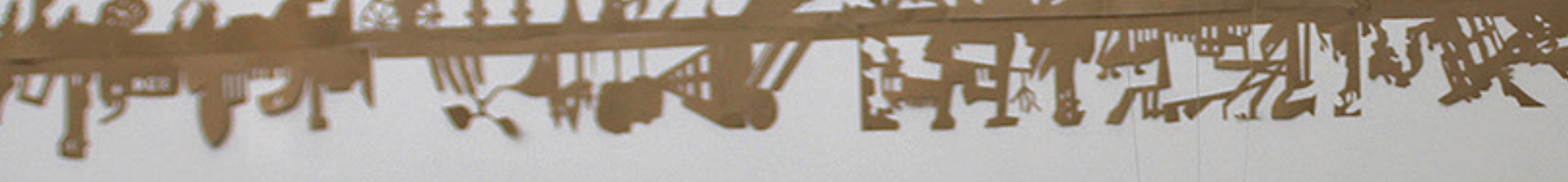
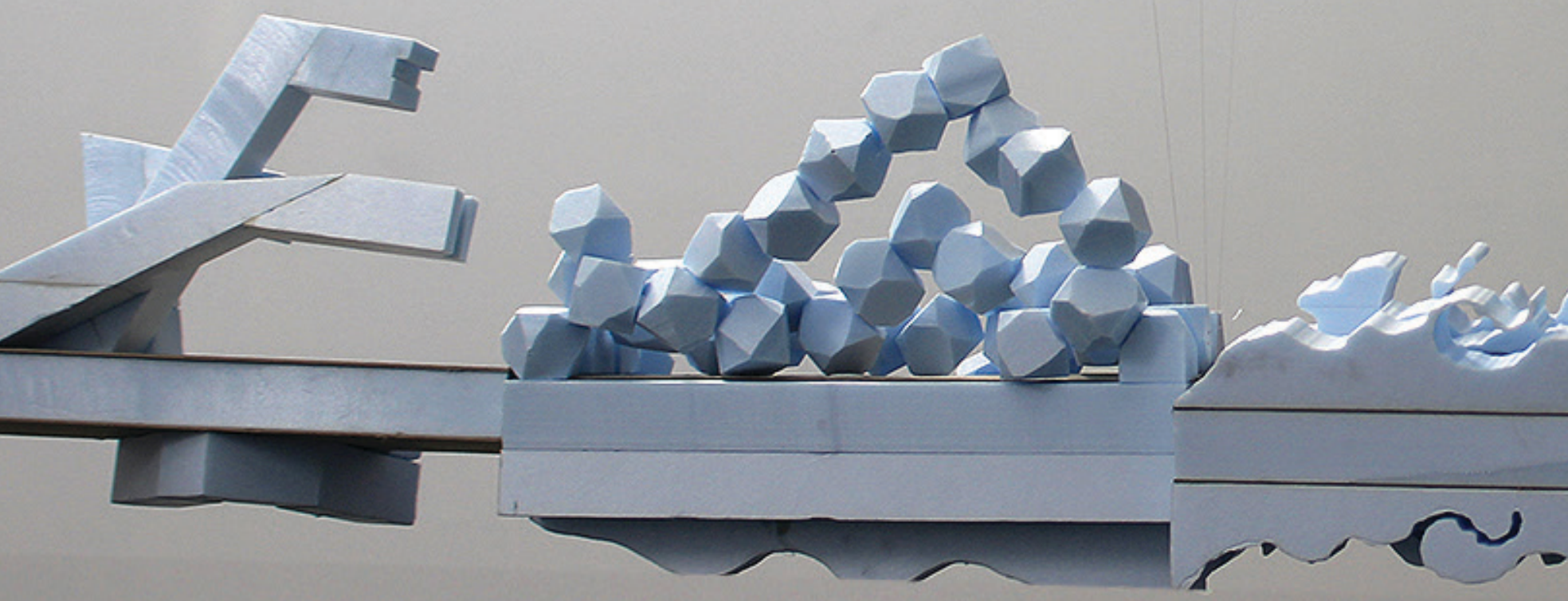